UNIVERSIDADE DE SÃO PAULO

ESCOLA DE COMUNICAÇÕES E ARTES

CAROLINA AZEVEDO DI GIACOMO

Espectadores em trânsito: identificação, imersão e distinção no Rio de Janeiro do início do século XX

São Paulo

2019 
Espectadores em trânsito: identificação, imersão e distinção no Rio de Janeiro do início do século XX

Versão original

Dissertação apresentada ao Programa de Pós-Graduação em Meios e Processos Audiovisuais da Escola de Comunicações e Artes da Universidade de São Paulo para obtenção do título de Mestre.

Área de concentração: Teoria, História e Crítica

Orientador: Prof. Dr. Eduardo Victorio Morettin

São Paulo 
Autorizo a reprodução e divulgação total ou parcial deste trabalho, por qualquer meio convencional ou eletrônico, para fins de estudo e pesquisa, desde que citada a fonte.

Catalogação na Publicação

Serviço de Biblioteca e Documentação

Escola de Comunicações e Artes da Universidade de São Paulo

Dados inseridos pelo(a) autor(a)

Di Giacomo, Carolina Azevedo

Espectadores em trânsito: identificação, imersão e distinção

no Rio de Janeiro do início do século XX / Carolina Azevedo

Di Giacomo; orientador, Eduardo Victorio Morettin. -- São

Paulo, 2019 .

179 p.: il.

Dissertação (Mestrado) - Programa de Pós-Graduação em Meios

e Processos Audiovisuais - Escola de Comunicações e Artes /

Universidade de São Paulo.

Bibliografia

Versão original

1. Primeiro cinema brasileiro 2. Cinema de atrações 3.

Automóvel 4. Espectatorialidade 5. Cultura visual I.

Morettin, Eduardo Victorio II. Título.

CDD 21.ed. - 791.43 


\section{Folha de aprovação}

Nome: Carolina Azevedo Di Giacomo

Título: Espectadores em trânsito: identificação, imersão e distinção no Rio de Janeiro do início do século XX

Dissertação apresentada ao Programa de Pós-Graduação em Meios e Processos Audiovisuais da Escola de Comunicações e Artes da Universidade de São Paulo para obtenção do título de Mestre.

Área de concentração: Teoria, História e Crítica

Aprovada em:

Banca examinadora

$\operatorname{Prof}^{\mathrm{a}}$. Dr ${ }^{\mathrm{a}}$.

Instituição:

Assinatura:

$\operatorname{Prof}^{\mathrm{a}} . \mathrm{Dr}^{\mathrm{a}}$. :

Instituição:

Assinatura:

Prof $^{\mathrm{a}} . \mathrm{Dr}^{\mathrm{a}} .:$

Instituição:

Assinatura: 



\section{Agradecimentos}

Ao Professor Eduardo Morettin pela compreensão, confiança e sensibilidade com que me orientou desde a Iniciação Científica.

Às Professoras Andrea Cuarterolo e Ana Laura Lusnich pela acolhida em Buenos Aires. Aos colegas de grupo e de programa, pela troca e torcida: Lila Foster, Daniela Giovana, Débora Brutuce, Erika Amaral, Izabel Cruz Melo, Isabella Goulart, Sávio Stocco, Danielle Carvalho, Ana Karicia Machado, Bárbara Felice, Giancarlo Gozzi, Alexandre Nakahara, Paula Pires. Ao parceiro Thiago Venanzoni, pela aventura compartilhada na representação discente.

À turma do cinema silencioso, pelo incentivo: Sheila Schvarzman, Alice Trusz, João Luiz Vieira, Rafael de Luna, Hernani Heffner. Ao Igor Andrade por, mesmo longe, estar tão perto. Aos funcionários de todos os arquivos e bibliotecas que visitei, em especial Rodrigo Manoel do MIS-RJ e Alexandre Miyazato da Cinemateca Brasileira, pelas inúmeras contribuições.

Aos amigos de casa e vida: Gabi Bitencourt, pelo exemplo, Dani Garroux, pelas aulas de interpretação, Fran Donatti, por me ensinar sobre ver e ouvir, Felipe Catalani, pelo afeto fundamental. Ao Danilo Do Carmo, pela construção, ao Pedro Lopes, pelas revelações, ao Thiago Miranda Tica, pelo carinho e força, ao Roberto Gerbi, pelo afeto que roda mundo, à Débora Brenga, pela amizade. Ao Matheus Thomaz, ao João Campos, à Marina Gurgel, ao Lucas Navarro, à Lili Psiquê. A Minari por várias palavras. Ao Christian Hayes pelos passeios. Ao Jorge DLM pela entrega. À Driciele Souza pela cumplicidade. À Glaucia P. Oliveira Nena por insistir em me ensinar o que é a amizade.

Ao Danilo Vieira e à Raphaella Padulla, pela presença solar e parceria cotidiana. Ao Arthur Lopes Ratinho, pelas conversas abissais e pela parceria tão antiga quanto sempre renovada. Ao Raul Arthuso pela aparição repentina de trucagem, pela terna presença multicolorida e por me fazer acreditar em criaturas fantásticas.

Às Professoras Luciana Corrêa de Araújo e Flavia Cesarino Costa, pelas leituras tão cuidadosas do relatório de qualificação e por tantos anos de incentivo carinhoso. Ao Professor Carlos Roberto de Souza, pelo interesse e amizade.

À minha mãe, Paula, e ao meu pai, João, pelo apoio incondicional. Aos meus irmãos, Marcos e Joaquim, pelas inspirações, no sentido de entrada de ar nos pulmões. 

A lacuna é nossa primeira informação.

Jean-Claude Bernardet em Historiografia clássica do cinema brasileiro 



\section{Resumo em português}

DI GIACOMO, Carolina Azevedo. Espectadores em trânsito: identificação, imersão e distinção no Rio de Janeiro do início do século XX. 179 p. Dissertação (Mestrado em Meios e Processos Audiovisuais) - Escola de Comunicações e Artes, Universidade de São Paulo, São Paulo, 2019.

Esta dissertação apresenta três exercícios historiográficos acerca da cultura visual carioca do início do século XX, em que se evidenciam aspectos contraditórios de relações de classe, gênero e origem, por meio de diferentes operações de identificação e distinção. $O$ primeiro capítulo analisa as imagens remanescentes de Circuito de São Gonçalo (Empresa F. Serrador, 1909), sobre a corrida de automóveis homônima, em diálogo com filmes estrangeiros semelhantes, buscando aproximar progresso e catástrofe. O segundo capítulo mapeia a presença dos simuladores cinematográficos no Brasil, que emulavam passeios de automóvel, e discute a experiência de seu espectador. Esses aparelhos são entendidos como um cenário no qual os presentes agiam como atores de uma encenação proposta pelo ambiente da atração. O terceiro capítulo sugere um percurso imaginário para o casal de caipiras que protagonizou o filme Sô Lotero e nhá Ofrasia com seus productos na Exposição (Labanca, Leal e Cia., 1908), hoje perdido. O encontro entre personagem ingênua e o universo cosmopolita condensou tanto o fascínio ligado aos signos da modernidade quanto a ansiedade provocada por eles.

Palavras-chave: 1. Primeiro cinema brasileiro; 2. Cinema de atrações; 3. Automóvel; 4. Espectatorialidade; 5. Cultura visual. 



\begin{abstract}
DI GIACOMO, Carolina Azevedo. Spectators in motion: identification, immersion and distinction in Rio de Janeiro at the beginning of the twentieth century. 179 p. Dissertação (Mestrado em Meios e Processos Audiovisuais) - Escola de Comunicações e Artes, Universidade de São Paulo, São Paulo, 2019.

This study presents three historiographic exercises concerning visual culture in Rio de Janeiro at the beginning of the twentieth century where contradictory social issues emerge from class, gender and origin relations by means of different operations of identification and distinction. The first chapter analyzes the remnant images of Circuito de São Gonçalo (Empresa F. Serrador, 1909), about the homonymous automobile race, under discussion with similar foreign movies, following convergences between progress and disaster. The second chapter maps the presence of cinematographic thrill rides in Brazil, which simulated automobile tours, and discusses their spectator experiences. These apparatus are pictured as a setting where those present behaved as actors of an enacting proposed by the attraction's ambience. The third chapter suggests an imaginary journey for the couple of caipiras who feature in the lost movie Sô Lotero e nhá Ofrasia com seus productos na Exposição (Labanca, Leal e Cia., 1908). The confluence of naive character and cosmopolitan milieu condensed both the modernity allure and its induced anxiety.
\end{abstract}

Keywords: 1. Brazilian early cinema; 2. Cinema of attractions; 3. Automobile; 4. Spectatorship; 5. Visual culture. 



\section{Sumário}

Prólogo _ 15

Introdução — 25

\section{Primeiro capítulo}

Circuito de São Gonçalo (Empresa F. Serrador, 1909): a iminência do acidente automobilístico como espetáculo moderno __ 43

A elite sobre rodas _ 43

Cinema da localidade__ 48

Perseguição automobilística___ 61

A morte do motor _ 68

A catástrofe como atração __ 81

\section{Segundo capítulo}

Espectadores em cena: mapeamento dos simuladores cinematográficos de viagem brasileiros__ 85

Porta aberta__ 85

Viagem instrutiva___ 91

Viagem excitante _ 102

Viagem fantasma __ 111

Última viagem _ 112

\section{Terceiro capítulo}

Os caipiras vão à Exposição Nacional: percurso imaginário de um filme perdido 123

Os caipiras vão ao Rio de Janeiro - e nós também _ـ_ 124

"Tão mudados estavam, com as novas paisagens" __ 129

A volta ao Brasil em um dia___ 135

Labaredas espetaculares__ 149

Corpos gigantes, visão panorâmica __ 158

"O roceiro que vai à cidade tem certeza trazer novidade" ___ 164

Considerações finais___ 169

Referências__ 171 



\section{Prólogo}

\section{Ver, tocar, possuir, destruir}

O cenário é a plataforma de uma estação de trem. Sobre os trilhos, uma locomotiva avança em nossa direção. Dificilmente alguém permaneceria aí, em atitude passiva diante de tal ameaça. Mas e se dissermos que a cena descrita é representada por um filme, projetado numa tela, dentro de uma sala de cinema? Neste caso, nenhum de nós, como espectadores, se levantaria correndo, temendo por sua vida. Afinal, que efeito pode uma imagem provocar em nossos corpos? Esta cena, muito conhecida dentro e fora do campo dos estudos cinematográficos, tem seu protótipo no filme Chegada do trem a estação de Ciotat (Arrivée d'um train en gare à la Ciotat, Société Lumière, 1895), ${ }^{1}$ parte do programa da célebre sessão de dezembro de 1895, que inaugurou a exploração comercial da exibição cinematográfica em Paris, na França. Tão famosa quanto o filme é a anedota que o acompanha, que conta da suposta reação de seus primeiros espectadores. Confundindo imagem e realidade, eles teriam gritado, desmaiado, corrido - com medo do avanço do trem para dentro da sala de projeção. Apesar de haver alguns registros de pânico em sessões cinematográficas - em primeiras fileiras de audiências não urbanas, sobretudo -, sabemos que este comportamento está longe de representar as reações mais comuns do público do período. ${ }^{2}$ Isso não impediu que desde o princípio, muito antes deste "mito de origem" ser reproduzido exaustivamente pela historiografia do cinema, tal estória já fosse bastante usada em sua divulgação como uma atração capaz de provocar respostas corporais em seus espectadores.

Os próprios filmes do primeiro cinema já tematizavam esse encontro entre personagens ingênuas e dispositivos modernos. Em A porta errada (Erreur de porte, Pathé Frères, 1904), por exemplo, um caipira confunde uma cabine telefônica com a latrina, impossibilitando seu uso por um apressado citadino que aguardava para fazer uma ligação. Já em Rube e Mandy em Coney Island (Rube and Mandy at Coney Island, Edison,

\footnotetext{
${ }^{1} \mathrm{O}$ filmes citados seguem o padrão Título em português (Título original, Empresa produtora ou produtor, ano). Os títulos originais foram retirados da filmografia encontrada em COSTA, Flavia Cesarino. $O$ primeiro cinema: espetáculo, narração, domesticação. São Paulo: Azougue Editorial, 2005. Quando o filme não é citado por Costa, as traduções são nossas.

${ }^{2}$ BOTTOMORE, Stephen. The panicking audience?: early cinema and the "train effect". Historical Journal of Film, Radio and Television, Vol. 19, No. 2. Londres: Taylor \& Francis, 1999; GUNNING, Tom. O cinema das origens e o espectador incrédulo. Revista Imagens, no. 5, Campinas, Unicamp, 1995.
} 
1903), um casal de campesinos aparece experimentando várias atrações do parque de diversões que havia sido inaugurado naquele mesmo ano em Nova York. Outros filmes colocam essas personagens, geralmente homens do campo, dentro da própria sala de cinema, representando a reação anedótica de maneira literal: desde A primeira vez que o camponês viu as imagens animadas (The countryman's first sight of the animated pictures, Paul's Animatograph Works, 1901), uma série de filmes faz graça da credulidade do caipira diante da imagem cinematográfica. Este sub-gênero, o de caipiras diante da novidade tecnológica, aborda a capacidade que o cinema teria de enganar - pelo menos alguns de seus espectadores. A primeira vez... mostra como um camponês é influenciado por três diferentes filmes: quando aparece uma mulher que dança, ele a imita empolgado; quando vê um trem que avança em sua direção, sai correndo para fora de quadro amedrontado; e quando, no último filme, aparece um casal apaixonado em um cenário rural, ele aponta para o homem projetado para depois bater a mão no próprio peito dizendo "me", "eu". ${ }^{3}$

Outro exemplo é Tio Josh na sessão de cinema (Uncle Josh at the moving-picture show, Edison, 1902), ${ }^{4}$ imitação do filme de Paul lançada por Edison no ano seguinte, que, diferente do primeiro, sobreviveu em sua integridade e acrescenta um final violento à cena. Tão forte é sua crença e tão intenso seu desejo de interação com as figuras projetadas, que tio Josh termina destruindo a tela e revelando a máquina e seu operador. Furioso com a interrupção do espetáculo, o responsável pela projeção ataca nossa personagem. O filme termina, então, em um "confronto empolgante", ${ }_{5}^{5}$ como descreve o catálogo da empresa produtora.

Vejamos mais de perto o caso de Tio Josh.... Um mesmo enquadramento é mantido por toda duração do curta: vemos o proscênio de um teatro de vaudevile, do ponto de vista de sua plateia. Do lado esquerdo, o camarote de tio Josh; do lado direito, o palco emoldurado pela cortina recolhida. Além do novo desfecho, Edison fez outra alteração significativa em sua versão, autopromovendo-se: logo de início, aparece sobre o palco escuro, por meio de sobreimpressão, ${ }^{6}$ uma cartela branca que diz "The Edison Projectin [g] Kinetoscop[e]". Depois disso, surge na tela o primeiro filme que aparece

\footnotetext{
${ }^{3} \mathrm{O}$ homem que aparece na tela parece ser ele mesmo, inclusive.

4 O filme pode ser visto no sítio online da Library of Congress no seguinte link: < https://www.loc.gov/item/00694324 >.

5 "Exciting encounter", no original.

${ }^{6}$ Procedimento comum nos chamados filmes de trucagem, que consiste em rebobinar a película de modo a reimprimir nela outras imagens. Cf. COSTA, Flavia Cesarino. O primeiro cinema: espetáculo, narração, domesticação. São Paulo: Azougue Editorial, 2005, p. 177.
} 
dentro do filme, identificado por alguns autores como Dançarina parisiense (Parisian dancer, Edison, 1897). ${ }^{7}$ Entretanto, ao ler a cartela que o introduz (figura 1), é impossível não pensar em Perigo parisiense, já que onde devia ler-se a letra "c" em dancer, dançarina, há um "g”, formando a palavra danger, perigo. ${ }^{8}$ Este não é um detalhe secundário já que a mulher representada como um dos perigos da cidade moderna tem certa recorrência na cultura daquela época, questão que retomaremos adiante.

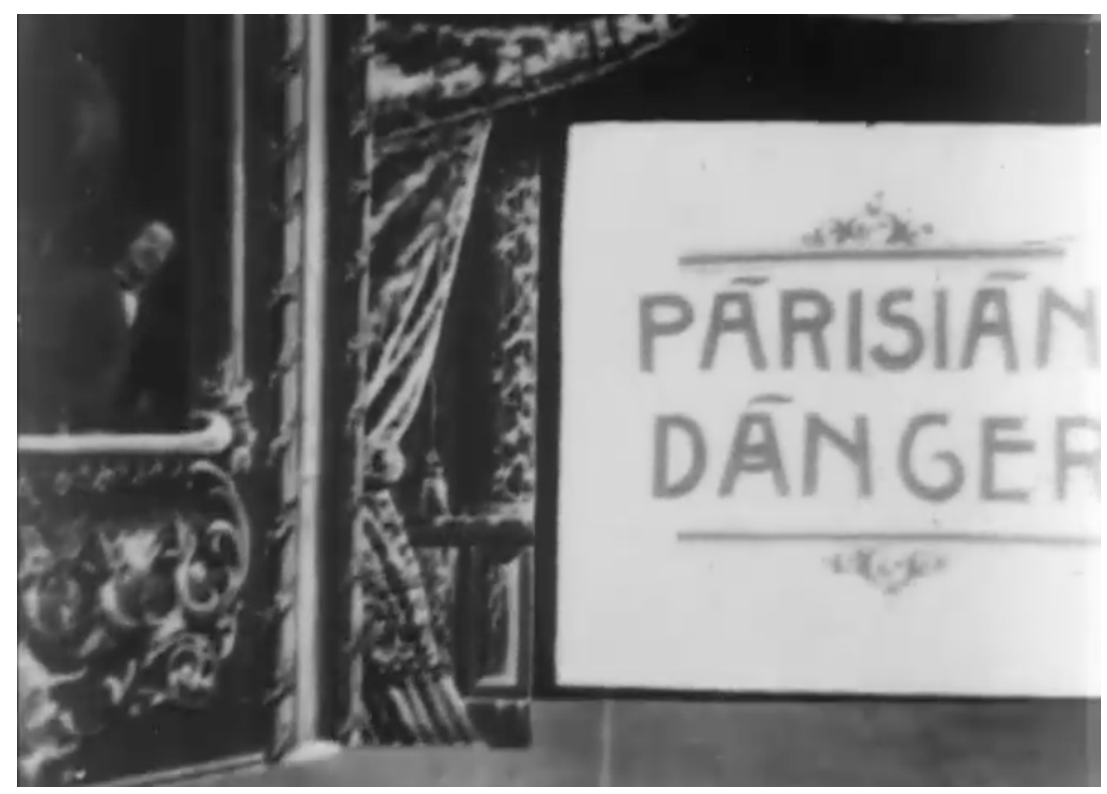

Figura 1 - Cartela do primeiro filme dentro do filme em Tio Josh na sessão de cinema (Uncle Josh at the moving-picture show, Edison, 1902).

Fascinado pela moça que mostra os tornozelos ao levantar a saia, tio Josh sai de seu camarote e, do palco, tenta imitá-la. O filme se encerra bruscamente e o homem parece decepcionado. Assim como a saia, que provoca ao mesmo tempo em que oculta, o pequeno filme não cumpre a expectativa do homem que tenta interagir com a mulher feita de sombras - simultaneamente presente e ausente. ${ }^{9}$

A próxima cartela diz "The Black Diamond Express", referindo-se ao filme de mesmo nome produzido por Edison, em 1896. O que vemos sobreimpresso na imagem não é aquele filme, mas outro bastante semelhante, no qual um trem se aproxima até

\footnotetext{
${ }^{7}$ ELSAESSER, Thomas. Cinema como arqueologia das mídias. São Paulo: Edições Sesc São Paulo, 2018, p. 149; HANSEN, Miriam. Babel and Babylon: spectatorship in American silent film. Cambridge, Mass.: Harvard University Press, 1991, p. 25; MUSSER, Charles. Before the Nickelodeon: Edwin S. Porter and the Edison Manufacturing Company. Berkeley / Los Angeles / Oxford: University of California Press, $1991,102$.

${ }^{8}$ Além disso, segundo Charles Musser, Parisian dance (1897) mostraria duas moças fantasiadas dançando, enquanto aqui há apenas uma bailarina. MUSSER, Charles. Op. cit., p. 102.

${ }^{9}$ HANSEN, Miriam. Op. cit., p. 26.
} 
ocupar quase toda a tela. Enquanto o veículo vem de longe pelas curvas do trilho, tio Josh aplaude e gesticula excitado. Quando percebe que a locomotiva não para de crescer, o caipira corre na direção contrária, retornando à segurança de seu camarote. É a citação explícita do mito. Se ver a bailarina provoca o desejo de aproximação, a visão de um trem que se acerca em alta velocidade provoca a reação oposta. $O$ perigo que a moça representa é tentador; já o perigo implicado no avanço de um trem, aniquilador.

O último filme projetado dentro do filme é "The country couple": em um cenário rural, um casal se encontra junto a um poço. O homem é atingido por uma alavanca e, quando a moça vai socorrê-lo, ele a agarra. Tio Josh tira o paletó, arregaça as mangas da camisa e se joga contra a imagem. Segundo o catálogo vendedor do filme, o caipira teria reconhecido sua própria filha na tela, o que serviria de motivo para a investida contra o homem da imagem. Quando tio Josh se aproxima, uma trucagem substitui a cena rural por uma tela branca. Ele dá com a cara no tecido, agarrando-o. O pano cai no chão do palco e finalmente revela os responsáveis pelo espetáculo: projetor e projecionista.

O que nos interessa na relação entre espectador inocente e imagem moderna é o que parece ser a consequência "lógica" deste encontro, a destruição. Que pode ser do próprio espetáculo, mas também (e talvez principalmente) de modos de ver e de viver, em alguma medida incompatíveis com o mundo urbano. Importante notar que a destruição, aqui, não é só a forma como termina a cena, mas a maneira com que ela culmina, em um "confronto empolgante". A destruição é a principal atração do show. A representação da cidade como máquina de moer caipiras é, aqui, fonte de prazer espectatorial moderno.

As três imagens às quais tio Josh reage podem ser descritas então por relações de perigo: a dançarina seria o perigo tentador; o trem, o perigo fatal; e, na cena da camponesa, o que corre perigo seria a "honra" do caipira. A resposta de tio Josh não é a mesma para todas essas situações. Como vimos, a visão das duas mulheres o leva à aproximação, ao passo que a visão do trem o leva à fuga para a segurança de seu assento. Assim como tio Josh foi imune ao trem e não teve acesso à dançarina, ${ }^{10}$ tampouco pode adentrar o mundo habitado pelo casal rural, por mais familiar que este lhe pareça. As trucagens (de sobreimpressão e de parada para substituição) contribuem para essa separação entre os dois universos representados - o da sala de cinema e o dos filmes. Ao analisar este curta, Miriam Hansen chama a atenção para o que ela chama de "exclusão

\footnotetext{
${ }^{10}$ HANSEN, Miriam. Babel and Babylon: spectatorship in American silent film. Cambridge, Mass.: Harvard University Press, 1991, p. 26.
} 
estrutural do espectador cinematográfico com relação ao espaço observado". ${ }^{11}$ No caso, a tentativa de burlar os limites entre o espaço da sala e o espaço da ilusão implica em catástrofe. $\mathrm{O}$ descontrole, fruto de uma crença ignorante, é o que estragaria a atração civilizada.

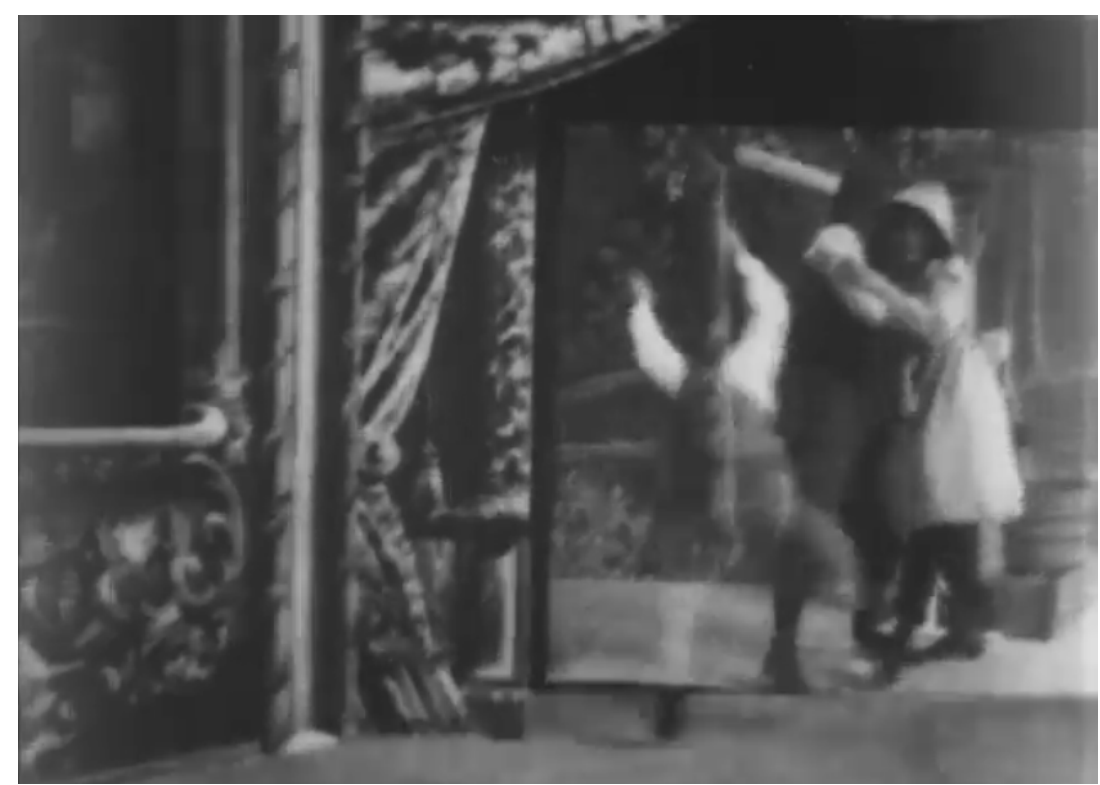

Figura 2 - Tio Josh ataca a imagem em Tio Josh na sessão de cinema (Uncle Josh at the moving-picture show, Edison, 1902).

Thomas Elsaesser compara a relação entre espectador e imagem cinematográfica com o que sugere a vitrine, que "também diz 'olhe, mas não toque', mas soluciona o conflito quando convida o observador ou curioso a entrar na loja, gesto que alivia o olho e promete controle mediante a plenitude do toque (...) com o ato da compra (resultando em 'posse')". ${ }^{12} \mathrm{O}$ ato de ver cria o desejo por tocar. Ao tentar tocar, o espectador busca uma espécie de posse - principalmente quando o objeto do olhar é um corpo que expressa feminilidade, seja pelo perigo provocante, no caso da dançarina, seja pelo perigo que supostamente corre nas mãos de outro homem, no da camponesa. Mas, ao tentar possuir, o caipira destrói. Segundo Michael Leja, tanto o observador da pintura trompe l'oeil quanto o espectador do filme de caipira no cinema são "visceralmente e corporalmente

11 HANSEN, Miriam. Babel and Babylon: spectatorship in American silent film. Cambridge, Mass.: Harvard University Press, 1991, p. 26.

${ }^{12}$ ELSAESSER, Thomas. Cinema como arqueologia das mídias. São Paulo: Edições Sesc São Paulo, 2018, p. 150 . 
engajados no ato de ver". ${ }^{13}$ Engajados, não necessariamente enganados. Miriam Hansen ${ }^{14}$ lembra que, ao mesmo tempo em que ridiculariza um comportamento considerado inadequado para a sala de cinema, Tio Josh... também evidencia diferentes componentes do próprio prazer espectatorial. ${ }^{15}$ No mesmo sentido, Tom Gunning explica que é justamente a "natureza inacreditável da própria ilusão" o que causa espanto no espectador. Para ele, "o que é exposto diante da plateia não é tanto o avanço iminente do trem mas a força do aparato cinematográfico. Ou para dizê-lo melhor, um demonstra a outra". ${ }^{16}$ Esses filmes não buscariam então a produção de um engano propriamente dito, mas sim a celebração da suposta capacidade de engano da imagem em movimento - que são coisas distintas. A pintura trompe l'oeil sugere que "o movimento físico de um observador em direção à imagem com a mão estendida talvez tenha menos a ver com um engano que com os desejos estimulados pelo quadro". ${ }^{17}$ Leja salienta inclusive que a "medida do sucesso de uma ilusão desse tipo era justamente sua capacidade de provocar uma resposta corporal - um impulso para tocar ou fugir"' ${ }^{18} \mathrm{O}$ caipira do primeiro cinema, assim como o observador da trompe l'oeil, é parte de um jogo explícito de estímulos e respostas corporais.

Em 1902, ano de produção de Tio Josh..., os filmes eram diferentes daqueles projetados no chamado "período da novidade" (definido por Charles Musser entre fins de 1895 e início de 1897), quando os filmes tendiam a ser mais curtos e seu impacto costumava residir em uma só ação. ${ }^{19}$ A própria forma de Tio Josh... brinca com essa disparidade: estamos assistindo a um filme composto por diferentes quadros, enquanto, dentro do filme, tio Josh assiste a três exemplos que referenciam diretamente aquele primeiro período. Isso nos leva a uma distinção entre os espectadores "primordiais", que

\footnotetext{
${ }^{13}$ LEJA, Michael. Seeing, touching, fleeing. In: MATHEWS, Nancy M. with Charles Musser. Moving pictures: american art and early film 1880-1910. Williamstown: Williams College Museum of Art, 2005, p. 165.

${ }^{14}$ HANSEN, Miriam. Babel and Babylon: spectatorship in American silent film. Cambridge, Mass.: Harvard University Press, 1991, p. 28.

${ }^{15}$ Como lembra Flavia Cesarino Costa: "Em contraste com a montagem invisível e a verossimilhança dos filmes narrativos posteriores, a montagem dos primeiros filmes faz alarde de sua própria presença, da manipulação que esta presença revela e de sua vinculação à construção de uma ilusão.” CF. COSTA, Flavia Cesarino. O primeiro cinema: espetáculo, narração, domesticação. São Paulo: Azougue Editorial, 2005, P. 177.

${ }^{16}$ GUNNING, Tom. O cinema das origens e o espectador incrédulo. Revista Imagens, no. 5, Campinas, Unicamp, 1995, p. 54.

${ }^{17}$ LEJA, Michael. Seeing, touching, fleeing. In: MATHEWS, Nancy M. with Charles Musser. Moving pictures: american art and early film 1880-1910. Williamstown: Williams College Museum of Art, 2005, p. 166.

${ }^{18}$ Idem, 167.

${ }^{19}$ MUSSER, Charles. Rethinking early cinema: cinema of attractions and narrativity. In: STRAUVEN, Wanda (Ed.). The cinema of attractions reloaded. Amsterdam: Amsterdam University Press, 2006, p. 400.
} 
formavam as plateias das primeiras sessões de cinema, e os espectadores "de primeira viagem", que tomavam contato com a projeção de filmes pela primeira vez (diferente da maior parte da plateia, supostamente acostumada a esse tipo de entretenimento). $\mathrm{O}$ historiador Yuri Tsivian conta que desde pelo menos 1907 memorialistas e historiadores do cinema já começaram a tentar estabelecer a figura de um "espectador ingênuo", que acreditaria na realidade do que é, na verdade, mera imagem. Para ele, "enquanto o espectador ingênuo é uma ficção historiográfica, o espectador 'inocente' (...) pode ser proposto, historicamente, como uma figura mais útil." ${ }^{20}$ Tsivian usa o termo "inocente" justamente no sentido de "não treinado", "não familiarizado". No caso de Tio Josh..., o tempo diegético tanto pode ser um passado dos primeiros anos de exibição cinematográfica (já que os pequenos filmes exibidos são dessa época), como pode ser o presente de 1902. Na segunda opção, tais filminhos remeteriam àquele período da novidade justamente para enfatizar a inexperiência do olhar do espectador-protagonista.

Desde então, os primeiros filmes são frequentemente usados para representar este evento que é a primeira ida de alguém ao cinema. Em determinado ponto do longametragem Tempo de guerra (Les Carabiniers, Jean-Luc Godard, 1963), por exemplo, Michelangelo, um dos garotos protagonistas, vai pela primeira vez ao cinema. As imagens projetadas na sessão referenciam justamente os Lumière: primeiro um trem avança, o que faz o menino cobrir o rosto; depois, a cena projetada satiriza Le repas de bébé (Société Lumière, 1895) e o garoto cai na gargalhada; por último, é exibido um filme que mostra uma mulher despindo-se e tomando um banho de banheira - mais uma vez o corpo feminino como objeto do olhar e do desejo de um espectador masculino. O menino se levanta do assento, sobe no palco e acaricia o corpo feito de imagem. E, assim como tio Josh estragara o espetáculo em 1902, o garoto também cai sobre a tela, derrubando-a. O curioso aqui é que, diferente do filme do primeiro cinema, no qual não vemos nenhum outro espectador em cena, Godard nos mostra a plateia e seus habitantes. No caso do filme dos anos 1960, os espectadores praticamente não se movem por toda a sua duração, os olhos vidrados na projeção, ignorando o "caipira", mesmo quando este os toca, passa por cima deles, sobe no palco, derruba a tela etc. A representação que Godard faz de seus espectadores não nos diz muito das plateias do primeiro cinema, claro, mas pode nos ajudar a questionar qual poderia ter sido a reação dos espectadores implícitos no espaço

\footnotetext{
${ }^{20}$ TSIVIAN, Yuri. Early cinema in Russia and its cultural reception. Chicago e Londres: The University
} of Chicago Press, 1998, p. 145. 
fora de quadro em Tio Josh.... E é difícil imaginar que o público daquela época teria agido de uma maneira tão passiva diante do inconveniente causado pela personagem.

Os filmes de caipira no cinema mostram diferentes reações que a imagem em movimento é capaz de provocar no corpo de um espectador não treinado. Esse gênero do primeiro cinema foi muitas vezes entendido pela historiografia como didático, no sentido de educar audiências não urbanas a se portar no cinema por meio da ridicularização de determinados tipos ficcionais. Elsaesser, nesse sentido, se pergunta se tal educação não estaria justamente na operação de distinção - na qual o espectador encontra para si uma autoimagem de superioridade em relação ao caipira. ${ }^{21}$

No Brasil, os registros das reações aos primeiros filmes sugerem uma operação semelhante. Segundo José Inácio de Melo Souza, “os membros da elite urbana [carioca e paulista] tiveram, na maioria esmagadora dos casos (...), uma reação tranquila, morna e civilizada diante do invento". ${ }^{22}$ Um dos poucos relatos que conhecemos na contramão dessa maioria é a do escritor modernista Oswald de Andrade, que diz ter visto um filme por volta de 1905 e tido a sensação do "espirrar da água que parecia vir sobre a plateia". ${ }^{23}$ Era mais comum o medo da escuridão da sala de cinema, que facilitaria o furto e o assédio, do que um entusiasmo exacerbado com a novidade. Melo Souza, para compreender esse fenômeno, cria a hipótese de que o pânico e a fuga "provavelmente eram reações impensáveis para a elite letrada [brasileira], pois demonstrariam falta de cultura ou de conhecimento sobre o que se passava na Europa". ${ }^{24}$

O mito de fundação do cinema e os efeitos espectatoriais a ele ligados mostram como a imagem cinematográfica traz a ideia de engano para o primeiro plano, no de explicitar a sua possibilidade. No filme de tio Josh, o caipira endereça seu olhar à câmera diversas vezes. Ele não vive em um mundo diegético fechado. ${ }^{25}$ Pelo contrário, ele reconhece a "presença" do espectador, chamando nossa atenção para o fato de estarmos diante de um espetáculo. O cinema como "janela que abre para um universo que existe em si e por si", ${ }^{26}$ é o cinema dito "clássico", cuja hegemonia começa a estabelecer-se

\footnotetext{
${ }^{21}$ ELSAESSER, Thomas. Cinema como arqueologia das mídias. São Paulo: Edições Sesc São Paulo, 2018, p. 149

${ }^{22}$ SOUZA, José Inácio de Melo. Imagens do passado: São Paulo e Rio de Janeiro nos primórdios do cinema. São Paulo: Editora Senac, 2004, p. 65. Grifo nosso.

${ }^{23}$ ANDRADE apud SOUZA, José Inácio de Melo, SOUZA, José Inácio de Melo. Imagens do passado: São Paulo e Rio de Janeiro nos primórdios do cinema. São Paulo: Editora Senac, 2004, p. 63.

${ }^{24}$ Ibidem., p. 242.

${ }^{25}$ Sobre a "precariedade" do efeito diegético no primeiro cinema, cf. COSTA, Flavia Cesarino. O primeiro cinema: espetáculo, narração, domesticação. São Paulo: Azougue Editorial, 2005, p. 32-33.

${ }^{26}$ XAVIER, Ismail. O discurso cinematográfico: a opacidade e a transparência. São Paulo: Paz e Terra, 2005, p. 22.
} 
somente na década de 1910 e cuja relação filme-espectador se caracteriza por uma "nãoefetividade sobre [sua] situação física", na sala de cinema. ${ }^{27} \mathrm{O}$ primeiro cinema se caracteriza justamente pelo endereçamento direto ao espectador. Ou seja, não é exatamente uma questão de sermos ou não enganados, mas de sempre sabermo-nos "peça de um jogo tácito de ilusões explícitas". ${ }^{28}$

O primeiro cinema foi, portanto, um cinema da descrença. É por isso que o caipira reage como reage - porque ele é, na cultura popular, figura crente por excelência. Ao tentar derrubar a barreira que separa a sala de cinema do mundo representado pelo filme, o caipira responde aos estímulos da encenação. Mas, ao mesmo tempo, ele contraria a lógica do próprio espetáculo, que mobiliza desejos mas não permite sua plena concretização. Não à toa, essa relação resulta, quase sempre, em destruição.

\footnotetext{
${ }^{27}$ XAVIER, Ismail. $O$ discurso cinematográfico: a opacidade e a transparência. São Paulo: Paz e Terra, 2005, p. 22.

${ }^{28}$ COSTA, Flavia Cesarino. O primeiro cinema: espetáculo, narração, domesticação. São Paulo: Azougue Editorial, 2005, p. 181.
} 


\section{Introdução}

Ao folhear um exemplar da revista Fon-Fon!, o leitor de 1908 encontrou uma enorme ilustração colorida, que tomava duas páginas (figuras 3, 4 e 5).

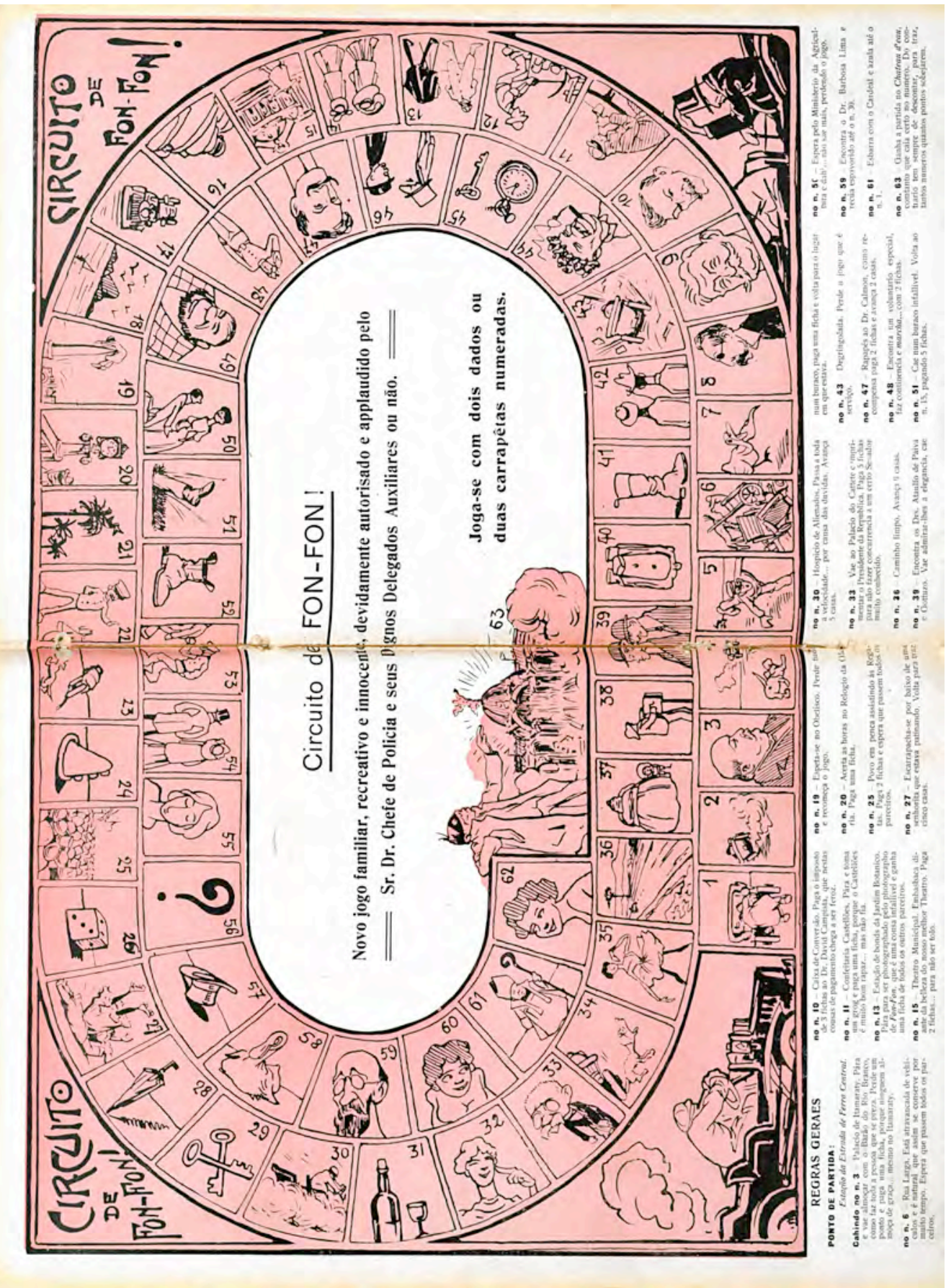

Figura 3 - Circuito de Fon-Fon. Fon-Fon!. Rio de Janeiro, 12/09/1908, p. 14-15. 


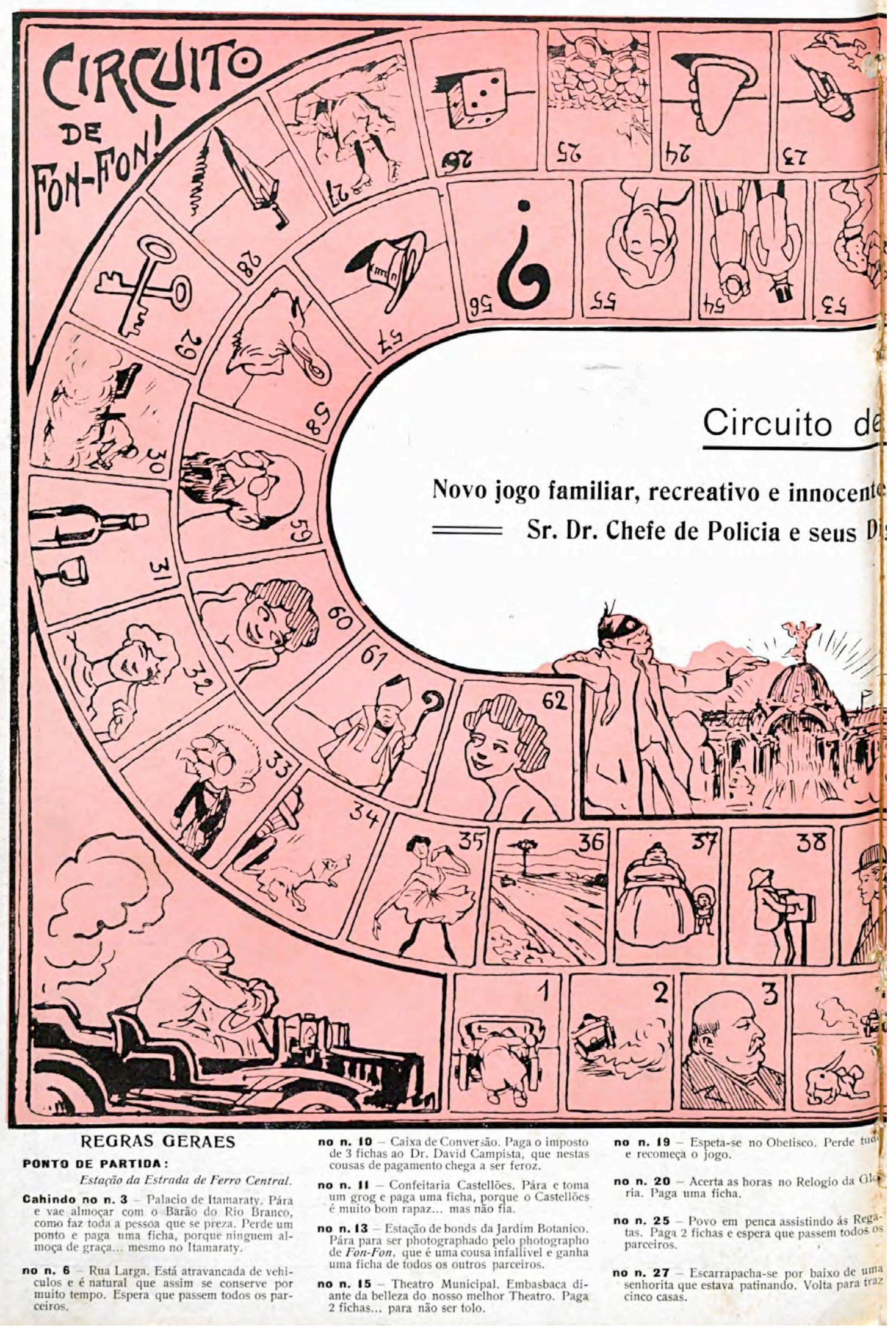

Figura 4 - Circuito de Fon-Fon. Fon-Fon!. Rio de Janeiro, 12/09/1908, p. 14. 


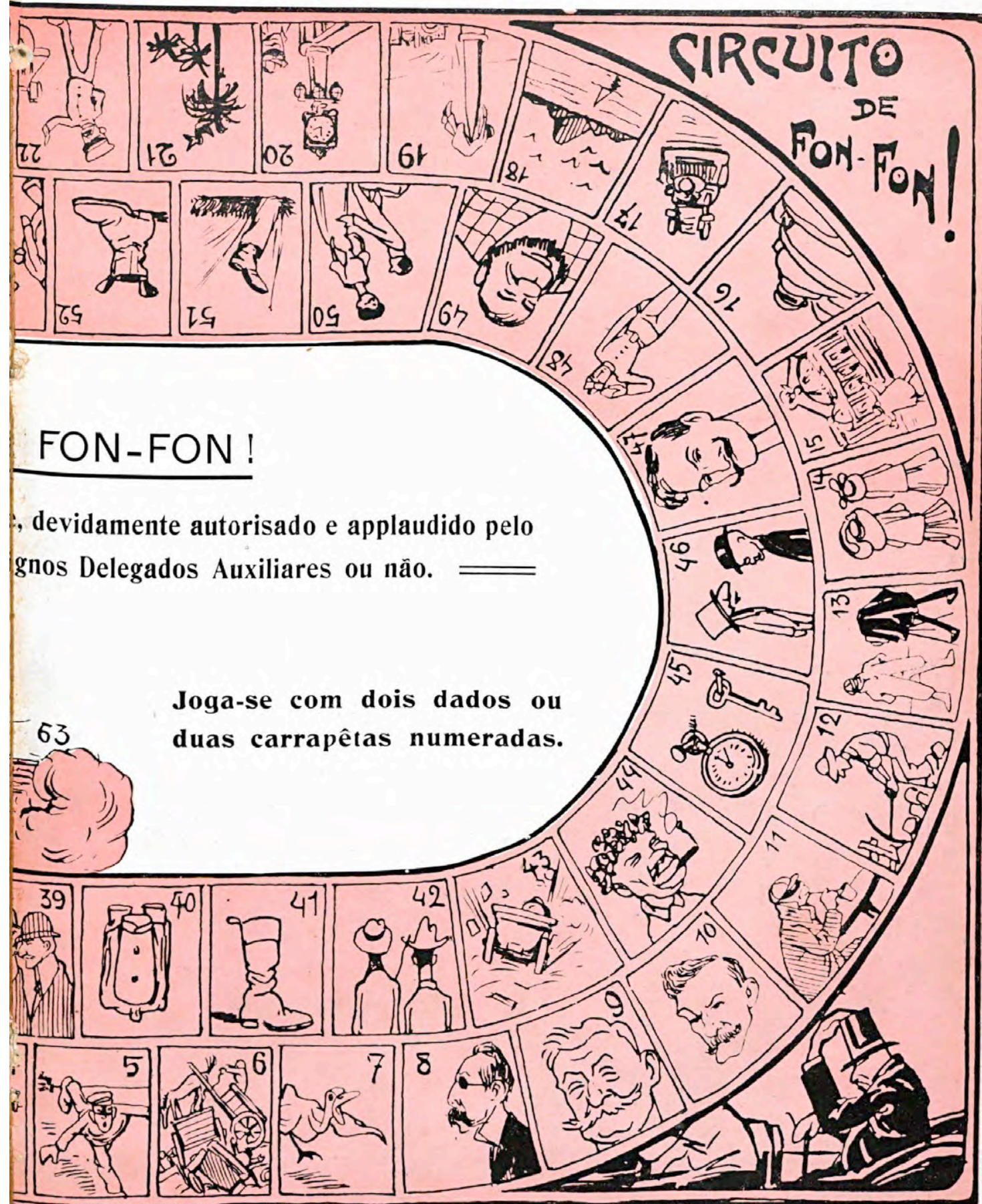

no n. 30 - Hospicio de Alienados. Passa a toda a velocidade... por causa das duvidas. Avança

no n. 33 Vae ao Palacio do Cattete c 'mprimentar o Presidente da Republica. Paga 5 fichas para não fazer concurrencia a um certo Seıado
muito conhecido.

no n. 36 - Caminho limpo. Avança 9 casas.

no n. 39 - Encontra os Drs. Ataulfo de Paiva

num buraco, paga uma ficha e volta para o lugar

no n. $\mathbf{4 3}$
serviço.

no n. 47 Rapapés ao Dr. Calmon, como recompensa paga 2 fichas e avança 2 casas, no n. 48 - Encontra um voluntario especial, continencia e marcha.... com 2 fichas. no n. $\mathbf{5 1}$ - Cae num buraco infallivel. Volta a no n. 5C - Espera pelo Ministerio da Agricul. no n. 59 - Encontra o Dr. Barbosa Lima no n. 61 - Esbarra com o Cardeal e azula até o comtanto que caia certo no numero. Do contantos numeros quantos pontos sobejarem.

Figura 5 - Circuito de Fon-Fon. Fon-Fon!. Rio de Janeiro, 12/09/1908, p. 15. 
O desenho é o tabuleiro de um jogo, o Circuito de Fon-Fon!. No centro da imagem, a cômica descrição já sugere que não se trata de um jogo comum, mas de uma ilustração satírica. Algumas das pessoas retratadas nas caricaturas eram membros de uma elite política conhecida pelos leitores, como o então presidente da República, Afonso Pena, ou o Barão do Rio Branco. O tabuleiro é composto por 63 casas numeradas, que se sucedem em caracol do ponto de partida, a Estação da Estrada de Ferro Central do Rio de Janeiro (atual Central do Brasil) até a chegada, um suntuoso palácio reluzente, o Chateau d'eau. Tratava-se de um enorme chafariz ornamental iluminado à luz elétrica que fazia parte da fachada do Palácio das Indústrias, construído naquele ano para a Exposição Nacional Comemorativa do $1^{\circ}$ Centenário da Abertura dos Portos do Brasil, um complexo de pavilhões que colocou em evidência o que era considerado mais moderno na época.

A instrução é simples: "Joga-se com dois dados ou duas carrapêtas numeradas". ${ }^{29}$ Subentende-se que cada jogador deve ter uma peça que o represente, avançando tantas casas quanto forem os números sorteados a cada rodada. As regras gerais, escritas na base da imagem, explicam o que o jogador deve fazer ao parar em cada uma das casas. No número 36, por exemplo, cujo desenho mostra uma estrada de terra ocupada por um automóvel solitário, o texto explica: "Caminho limpo. Avança 9 casas".

O percurso fictício proposto pelo jogo passa por diferentes pontos de encontro da gente rica do Rio de Janeiro daquele tempo, como o Teatro Municipal, o Jardim Botânico, avenidas importantes, uma confeitaria da moda. Ao longo da partida, são vários os compromissos "elegantes", como um almoço no Palácio do Itamaraty ou a saudação ao presidente no Palácio do Catete. O jogo condensa diferentes aspectos que nos interessam: o formato de circuito, que enfatiza um percurso pela cidade; o caráter fragmentário, que une diferentes cenas do cotidiano carioca; a ênfase na interação entre imagem e observador, que atua, no caso, como jogador. Assim como no jogo, os três capítulos que compõem esta dissertação são marcados, em sua forma, por trajetos fictícios, pela justaposição de cenas (extraídas de diferentes modos de representação - cinema, jornalismo, literatura, ilustração e fotografia) e pelo foco na relação entre imagens e seus espectadores.

Agora, a partir de sugestões do tabuleiro, passaremos, nesta introdução, por alguns episódios passados no Rio de Janeiro do início do século XX, entre eles os três desenvolvidos em cada um dos capítulos.

\footnotetext{
${ }^{29}$ Nesta, como em todas as outras citações de textos antigos, mantivemos a ortografia original.
} 
O motorista de automóvel, ou como era chamado na época, em francês, o chauffeur, personagem principal do jogo proposto pela Fon-Fon!, foi figura fundamental para a revista. Ele aparece no canto inferior esquerdo do tabuleiro, no ponto de partida: com atitude agressiva, vai montado em sua máquina, soltando fumaça (figura 6). No lado oposto (figura 7), quem ganha destaque é o passageiro, que segura sua cartola para que ela não saia voando com a velocidade do veículo.

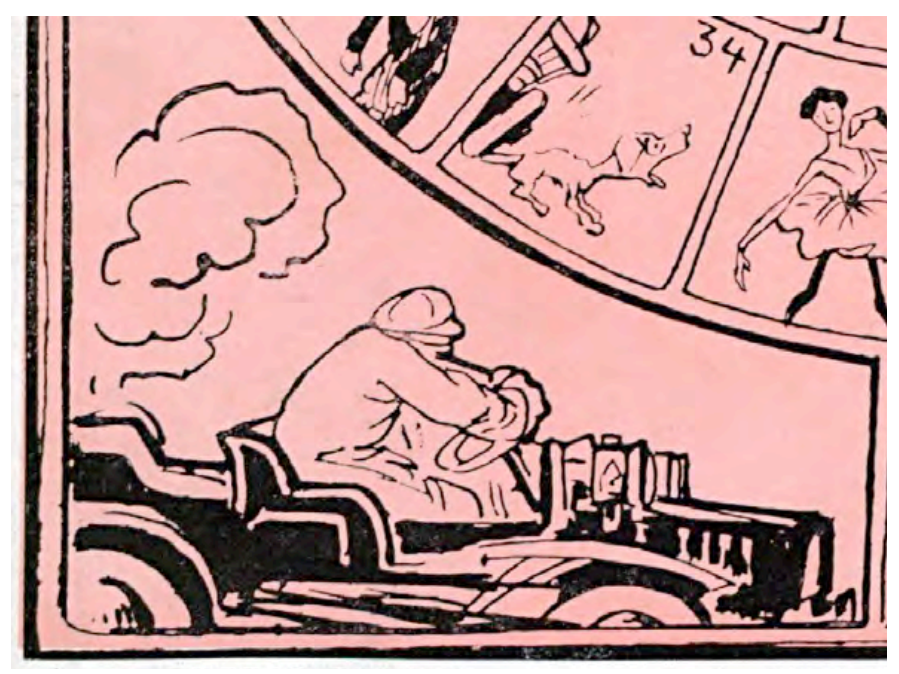

Figura 6 - Circuito de Fon-Fon. Fon-Fon!. Rio de Janeiro, 12/09/1908, p. 14, detalhe.

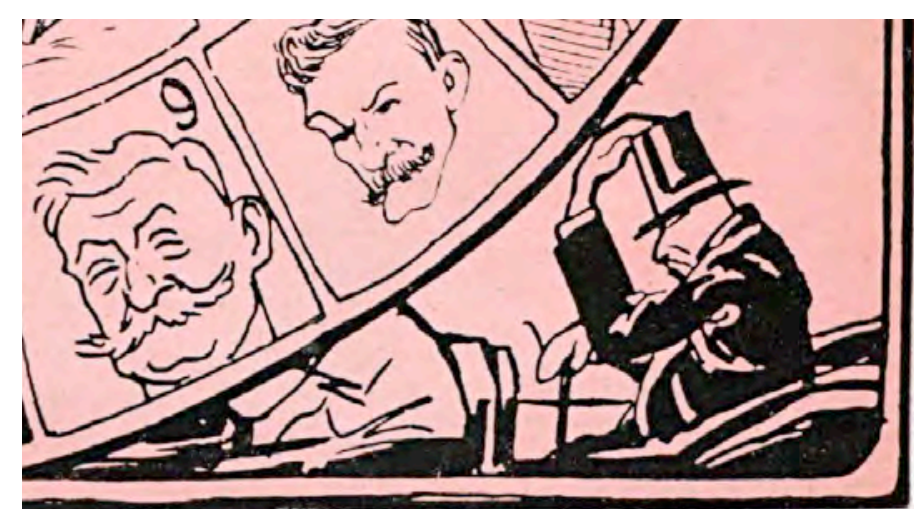

Figura 7 - Circuito de Fon-Fon. Fon-Fon!. Rio de Janeiro, 12/09/1908, p. 15, detalhe.

A essa altura, setembro de 1908, data de publicação do jogo, o leitor de Fon-Fon! já estava habituado a esses tipos, estampados em suas capas desde a estreia, em abril do ano anterior (figuras 8, 9 e 10). Todo o seu projeto editorial era baseado na sobreposição do repórter jornalístico com o motorista automobilístico, figura que será representada inúmeras vezes naquelas páginas, mantendo sempre o jeito provocador. 

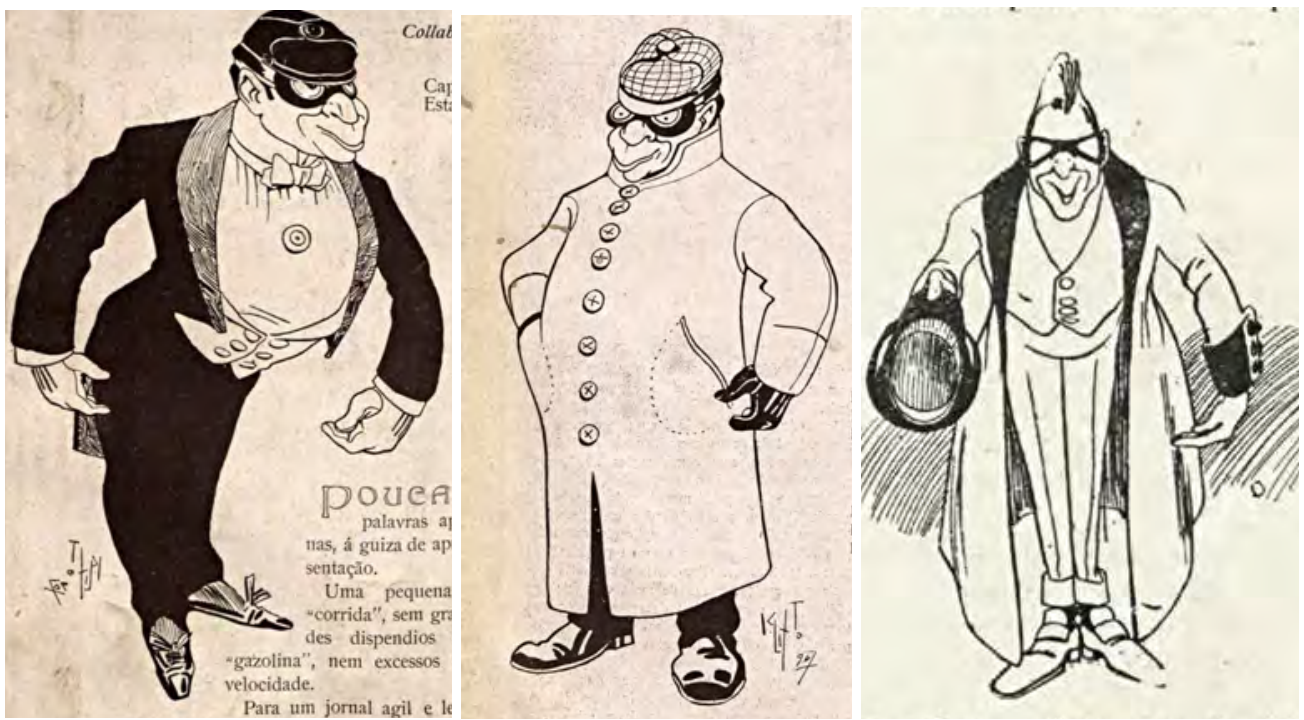

Figuras 8, 9 e 10 - Fon-Fon!. Rio de Janeiro, 13/04/1907, p. 3 e 4; Idem. 16/04/1910, p. $21 .^{30}$

Esse tipo de revista semanal ilustrada, segundo Monica Pimenta Velloso, traduzia "formas concretas de convívio em relação ao moderno; [davam] conselhos e sugestões, [apresentavam] jogos de entretenimento, piadas e lazer". Ainda segundo a autora,

\begin{abstract}
as revistas (...) tais como O Malho, Fon-Fon!, Tagarela, Para Todos, destinam-se ao grande público. Preferencialmente operacionalizam a ideia do moderno na vida cotidiana, buscando familiarizar os seus leitores com as novas coordenadas espaciotemporais. Diante do panorama cambiante das metrópoles, elas mostram um lugar confortável, um ponto de referência, enfim, possibilidades de participação. ${ }^{31}$
\end{abstract}

A descrição dá o tom da publicação: "Semanario alegre, politico, critico e esfusiante. Noticiario Avariado, Telegraphia sem Arame, Chronica Epidermica. Tiragem: 100.000 Kilometros, por ora." ${ }^{32} \mathrm{O}$ chofer condensa esse espírito moderno e divertido, transitando em alta velocidade pelas ruas da cidade, em busca de encontros e experiências excitantes, registrando tudo em forma de textos curtos, bem-humorados e sarcásticos, em que abundam o vocabulário técnico ligado ao automóvel.

\footnotetext{
${ }^{30}$ As três ilustrações são assinadas por K. Lixto, pseudônimo de Calixto Cordeiro (1877-1957), caricaturista, ilustrador e pintor que, junto com Raul Pederneiras, cuidava da direção artística de Fon-Fon!. Nesta época, ele já havia colaborado com diversos periódicos, como as revistas Tagarela, Kosmos e TicoTico.

${ }^{31}$ VELLOSO, Monica Pimenta. As distintas retóricas do moderno. In: OLIVEIRA, Claudia de; VELLOSO, Monica Pimenta; LINS, Vera. O moderno em revistas: representações do Rio de Janeiro de 1890 a 1930. Rio de Janeiro: Garamond, 2010, p. 50.

${ }^{32}$ Fon-Fon!. Rio de Janeiro, 13/04/1907, p. 3.
} 
O motorista de automóvel como contraventor e mesmo assassino é frequente nas páginas de Fon-Fon! e também de outras revistas ilustradas do período, como $O$ Malho, ainda que em representações menos heroicas.

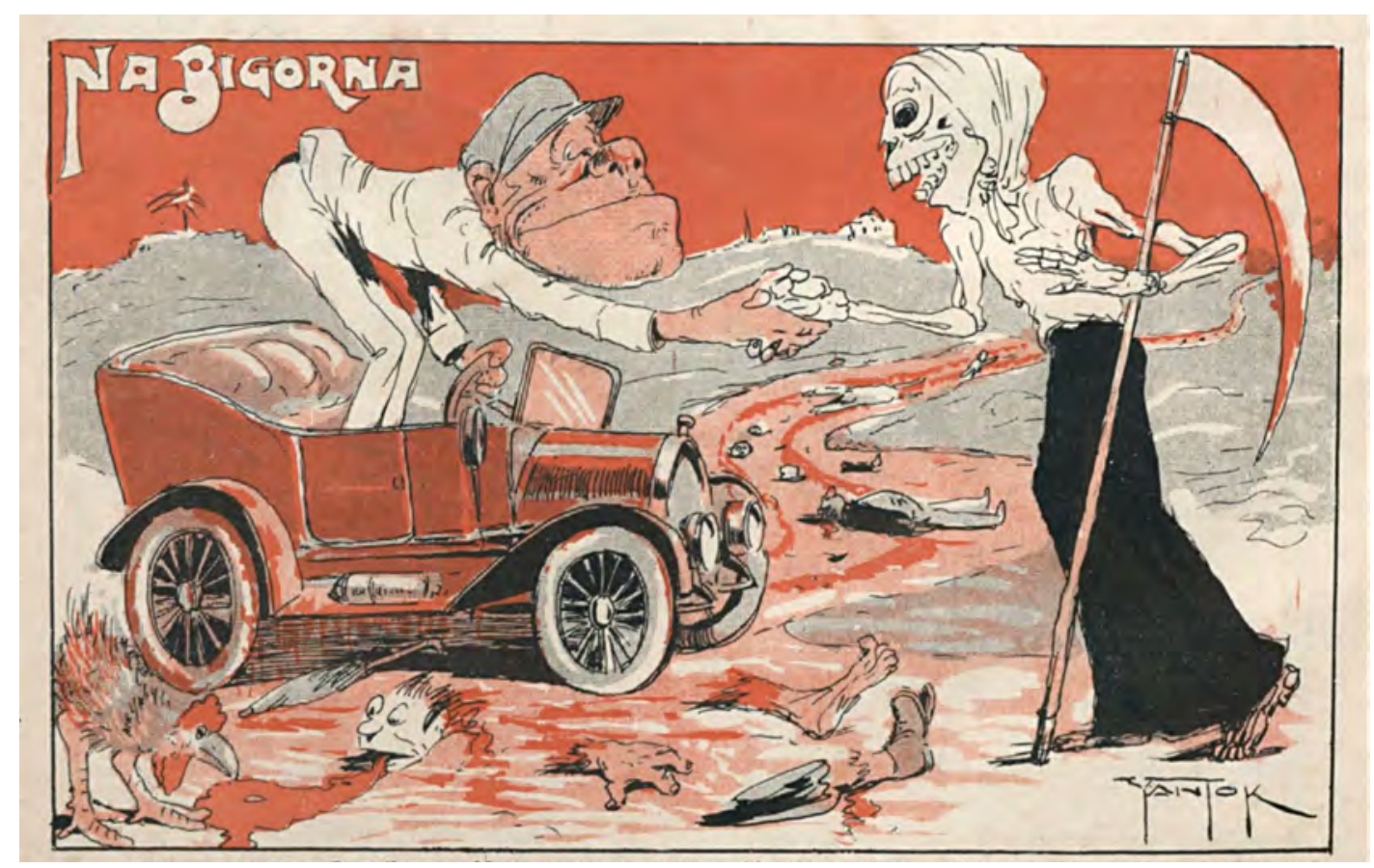

Figura 11 - Na Bigorna. O Malho. Rio de Janeiro, 21/12/1912, p. 26.

Nesta charge (figura 11), a morte dá as mãos ao chofer em agradecimento pelo serviço prestado, por cima de membros decepados e corpos mutilados - índices da passagem da máquina motorizada. A legenda diz:

\footnotetext{
Madame Morte ao Chauffeur: - Meus parabens, collega, é incalculável o auxilio que me estás prestando para aliviar o mundo do superfluo das existencias. Confesso que com este calor barbaro, já me iam faltando as forças para manejar a foice. Bravo! Continúa... mas cuidado com a lei de Lynch, hein!... ${ }^{33}$
}

E mesmo na Fon-Fon!, que tanto valorizou o chofer, seu heroísmo parece estar intimamente ligado ao perigo que ele representa para qualquer um que estiver em seu caminho (figura 12).

\footnotetext{
${ }^{33}$ Na Bigorna. O Malho. Rio de Janeiro, 21/12/1912, p. 26. "Lei de Lynch" se refere ao capitão norteamericano que, durante a guerra da independência dos Estados Unidos, praticava o que ficou conhecido depois como linchamento.
} 


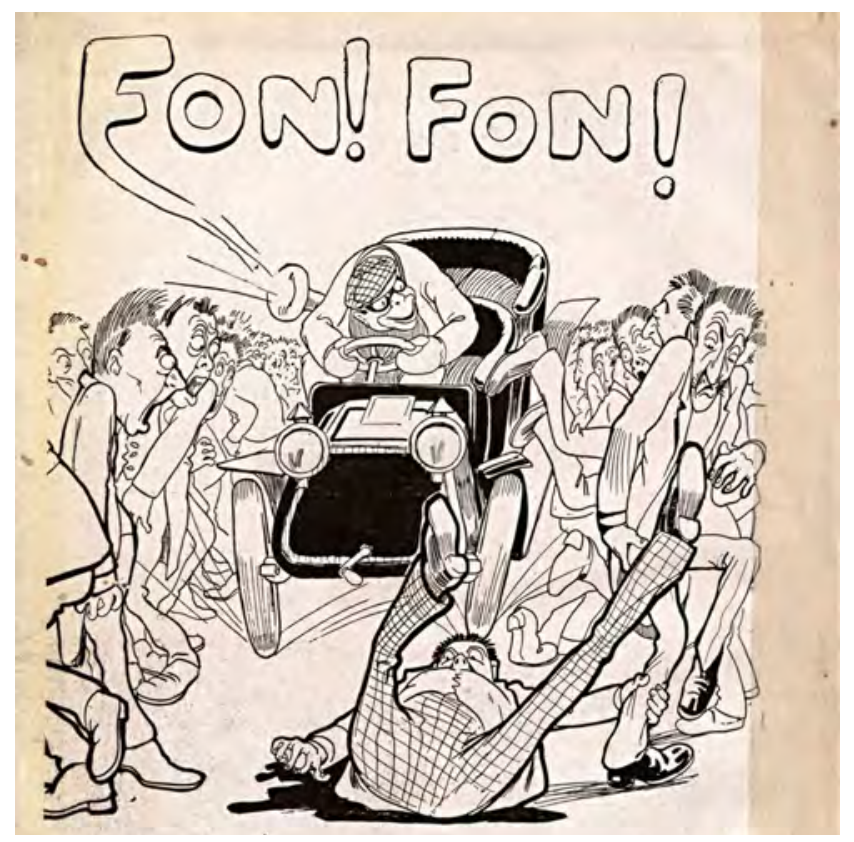

Figura 12 - Fon-Fon!. Rio de Janeiro, 13/04/1907, p. 6.

A relação entre policiais e motoristas também é tema de inúmeras representações publicadas nas revistas ilustradas. Aqui (figura 13) a briga é retratada em uma charge sobre um tipo de situação que parece se tornar cada vez mais cotidiana naqueles anos, publicada em 1911 n'O Malho.

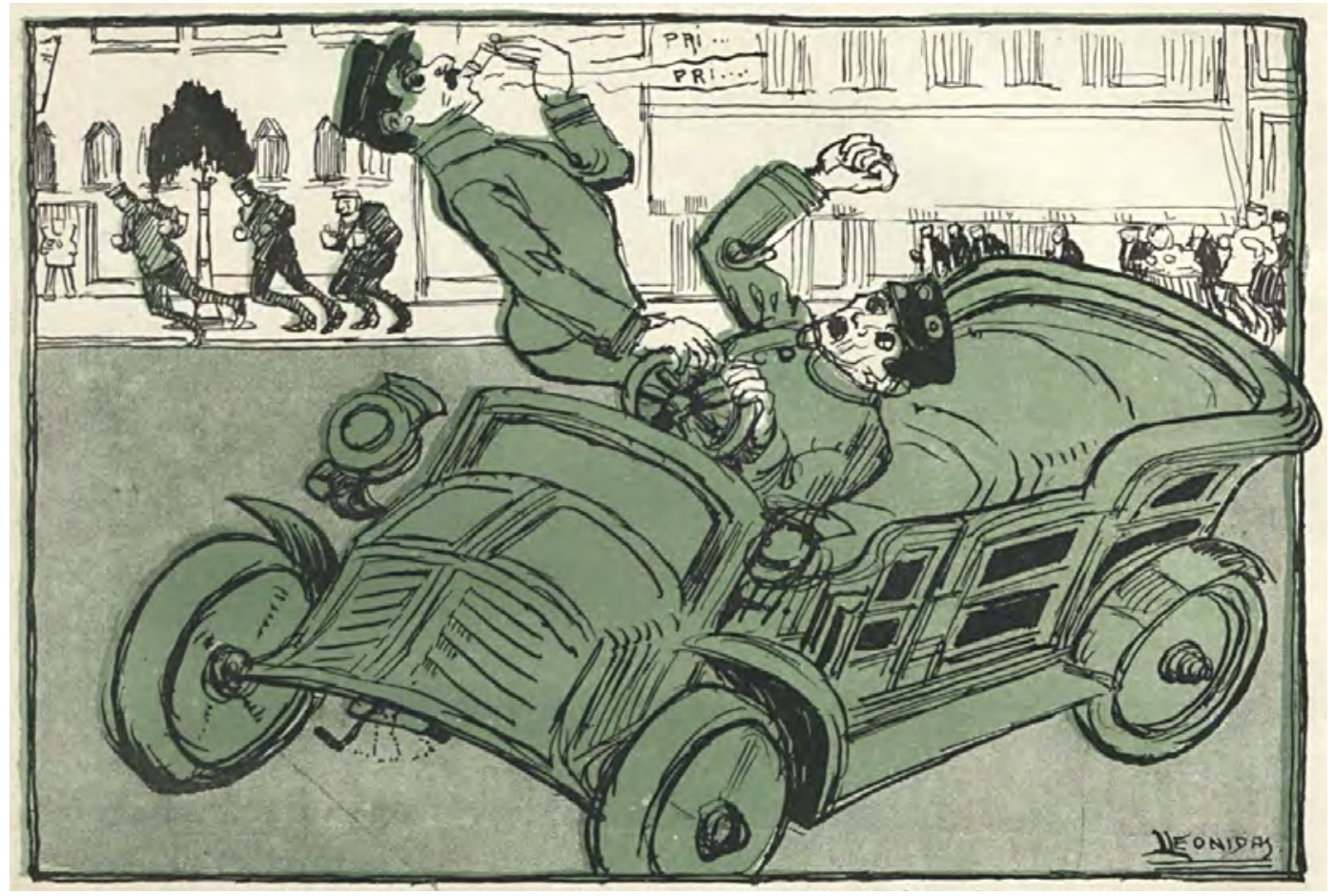

Figura 13 - O Rio em flagrante: instantaneo de um facto. O Malho. 14/01/1911, p. 36. 
A legenda diz:

\begin{abstract}
A carreira louca dos automoveis está na ordem do dia. Os ultimos atropellamentos fataes não commoveram os chauffeurs e ainda no domingo passado, na Avenida, um guarda civil tomou corajosamente de assalto um automovel, que passava em vertiginosa carreira, e intimou o motorista a diminuir a marcha. Sendo desobedecido, feriu-se dentro do vehiculo um duello de apitos e sôcos, que muito divertiu os transeuntes. Por fim, o automovel foi cercado, o chauffeur preso e, como no Quartel General de Abrantes, tudo ficou como d'antes. Salve-se quem puder!
\end{abstract}

Motorista e policial são aproximados pelo uniforme, mas distanciados nos papéis que exercem nas ruas da cidade em disputa. $\mathrm{O}$ embate expressa o choque entre lei e privilégio.

Voltando ao Circuito, suponhamos que, lançando os dados para dar início à partida, chegamos à casa de número 13 (figura 14). A legenda diz: "Estação de bonds da Jardim Botânico. Pára para ser photographado pelo photographo de Fon-Fon, que é uma cousa infallivel e ganha uma ficha de todos os outros parceiros". Na ilustração, vemos um chofer posando para a câmera, todo metido.

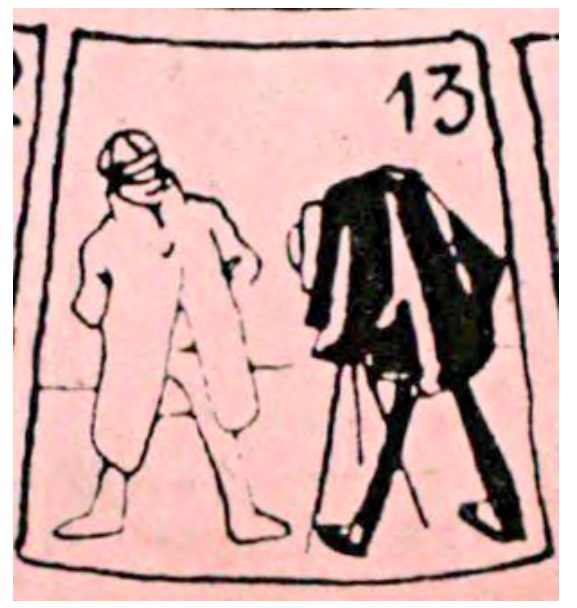

Figura 14 - Circuito de Fon-Fon. Fon-Fon!. Rio de Janeiro, 12/09/1908, pp. 14-15, detalhe.

De fato, muitos trabalhadores desta profissão emergente foram registrados pelas kodaks da Fon-Fon! e de outras revistas cariocas da época. No exemplo seguinte (figura 15), ele ocupa o centro da imagem, de corpo inteiro. 


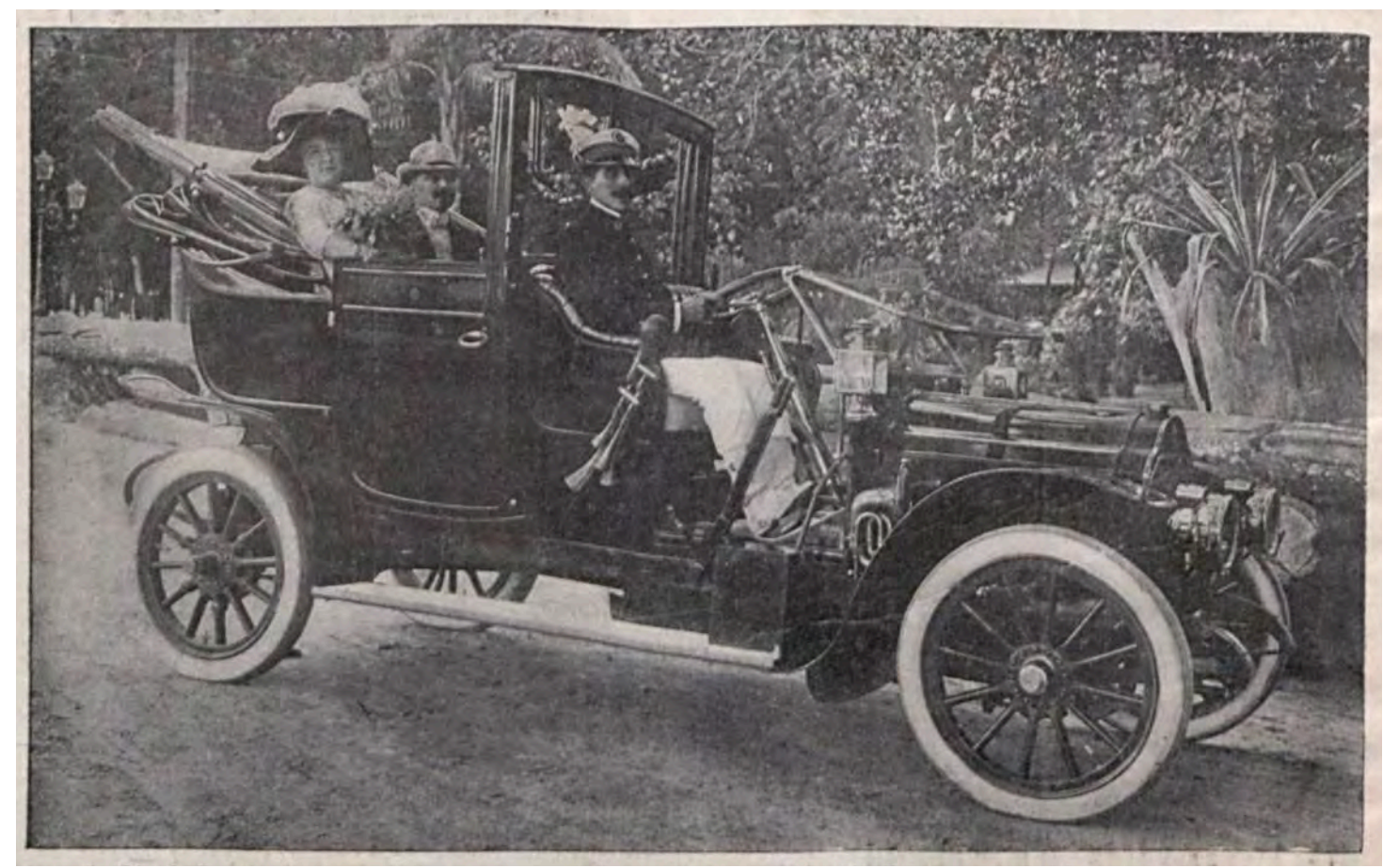

Figura 15 - Corso elegante. O Malho. Rio de Janeiro, 17/12/1910, p. 51.

A foto foi tirada em um corso - carreata em que a elite exibia-se montada em suas carruagens ou automóveis, próprios ou alugados. Os proprietários vão no banco de trás e quem ganha destaque é o chofer, cujo nome completo até aparece na legenda, que diz o seguinte:

Auto n. 1.432, do Dr. Castro Peixoto (em companhia de sua esposa D. Zizi Peixoto), premiado em $1^{\circ}$ logar, no corso effectuado no campo de S. Cristovão, em 14 de Novembro // Chauffeur: Edmundo de Carvalho. Os premios foram concedidos aos autos mais limpos com chauffeurs mais bem fardados.

Parte da agenda semanal da elite, a partir de 1907, os corsos eram um momento especial no jogo da exibição pública do ver e ser visto. O chofer, um dos "itens" avaliados na competição, mais parece um acessório que, assim como o próprio carro, denota a riqueza dos proprietários. Estes eventos eram constantemente filmados e os filmes eram posteriormente exibidos na cidade. Nenhum deles sobreviveu até nós, mas são vários os títulos compilados pela Filmografia Brasileira: ${ }^{34}$ Corso de Botafogo (PhotoCinematographia Brasileira), O corso de 19 de fevereiro (William e Cia), O corso de

\footnotetext{
${ }^{34}$ Base de dados da Cinemateca Brasileira que organiza e disponibiliza informações coletadas em diversas fontes sobre a produção audiovisual do país desde 1897 até hoje. Disponível em: < http://bases.cinemateca.gov.br >.
} 
carruagens na exposição (Empresa Paschoal Segreto) e $O$ corso das quartas-feiras na Avenida Beira Mar são só alguns exemplos, todos de 1908.

Os motoristas, que exerciam também o papel de mecânicos, eram em geral imigrantes que haviam aprendido o ofício em seus países de origem, na Europa. E o status da profissão estava em constante negociação. Por exemplo: nos anúncios das páginas dos classificados da época, os motoristas são listados como trabalhadores, não como "criados", ${ }^{35}$ mas são várias as piadas publicadas na Fon-Fon! sobre essa distinção. Neste chiste, por exemplo, faz-se graça da tentativa do motorista de se diferenciar dos outros empregados de uma família:

\footnotetext{
Um dos nossos ricaços dá ordem ao seu chauffeur para ir comprar uma fructas na cidade. / - Isto é serviço para os criados, responde arrogantemente o chauffeur. / - Ah! E qual é a sua obrigação? / - A minha? Tratar do automovel e conduzir quem o patrão mandar... / - Pois então prepare o automovel e leve á cidade o copeiro que comprará as fructas! ${ }^{36}$
}

Outro exemplo, de 1912: “- É um typo curioso aquelle! Sahe sempre de capa, bonet e oculos de chauffeur, para fazer suppor que tem automovel! / - É o que se chama uma auto-sugestão". ${ }^{37}$ Interessante notar a força dos elementos distintivos, os mesmos que compunham o figurino do repórter da revista.

Estes elementos - capa, boné (ou boina) e óculos - eram apetrechos que associavam o sujeito ao mundo dos esportes importados, a que tinham acesso os proprietários dos veículos. Nos primeiros anos de difusão do automóvel entre nós, tanto o proprietário como o empregado podiam ocupar a função de chofer, bastando para isso conduzir o veículo. O que vai diferenciá-los é justamente a vestimenta. No caso do empregado, como já vimos (figura 15), o figurino é um uniforme, com direito a quepe. A foto abaixo (figura 16) mostra quatro homens dentro de um automóvel: três de chapéu de palha (dois no banco de trás e um que dirige e é chamado de "chauffeur" pela legenda) e um de quepe (que ocupa o assento de passageiro dianteiro e é chamado de "habil mechanico"). Não é, portanto, necessariamente a posição dentro do carro que distingue quem é proprietário de quem é trabalhador, mas o código de vestimenta, que parece funcionar como uma espécie de figurino na cena social.

\footnotetext{
${ }^{35}$ Como nos exemplos: Jornal do Brasil, 04/09/1909, p. 2, Jornal do Brasil, 04/11/1909, p. 2, Jornal do Brasil, 07/05/1908, p. 2.

${ }^{36}$ Fon-Fon!, 17/08/1912, p. 55.

${ }^{37}$ Fon-Fon!, 03/02/1912, p. 57.
} 


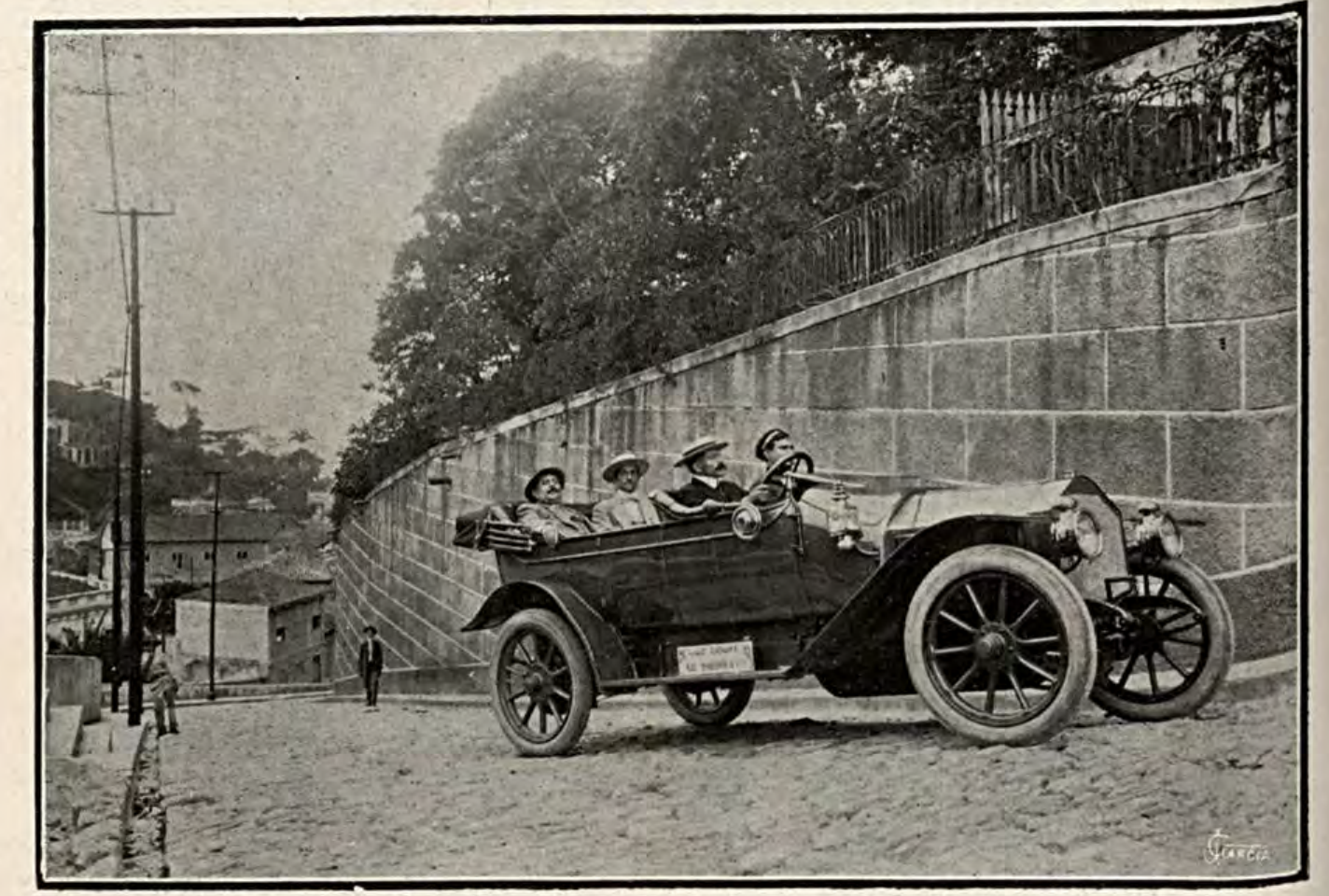

O magnifico automovel da marca Luc, Court \& C., de Lyão (França), cujos depositarios nesta capital são os Srs. Gil

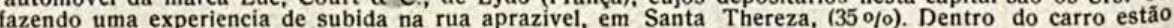
os Srs. Carlos Ribeiro e Rocha Gomes e ao lado do chauffeur o habil mechanico Aloês Gonin.

Figura 16 - Notas Automobilisticas. Fon-Fon!. Rio de Janeiro, 16/11/1912, p. 52.

Um dos minidramas que Arthur Azevedo publicou no jornal O paíz entre 1906 e 1908 trata deste tema, sugerindo os sacrifícios adotados na busca por pertencimento nos corsos de automóveis. Depois de uma discussão sobre a necessidade de um novo vestido para a próxima carreata, um casal termina a conversa deste modo:

Torres - Envergonhei-me porque a modista que te fez o vestido, e que ainda não foi paga, lá estava na Avenida Beira-Mar de pé, ao lado do marido, e, quando passamos no nosso carro, nos lançou um olhar significativo e teve um sorriso irônico.

Mme Torres - Acredito, mas o sorriso irônico não foi porque o vestido não estivesse pago... Se assim fosse, haveria muitos sorrisos irônicos às quartasfeiras, durante o corso... O sorriso era irônico, porque o vestido figurava pela terceira vez... - Não! não! tem paciência, Torres, faze das tripas coração, mas eu quero, seja como for, um vestido novo para quarta-feira que vem! $!^{38}$

Ao fazer graça da suposta futilidade da personagem feminina, o texto sugere o papel crucial da moda como marcador de superioridade social e a importância de tomar parte nesses corsos para mostrar-se como membro de uma elite atualizada.

\footnotetext{
38 AZEVEDO, Artur. Teatro a Vapor - Organização, introdução e notas de Gerald M. Moser (do State College, Pensilvânia, EUA). São Paulo: Editora Cultrix, 1977, pp. 157-158.
} 
Ao que parece, conforme o número de proprietários habilitados aumenta, ${ }^{39}$ os antigos choferes passam a trabalhar nas chamadas "garages" como mecânicos e motoristas de carros de aluguel. E é nos anúncios de automóveis, que também começam a aparecer na imprensa brasileira por esses anos, e nas propagandas dessas novas garagens, que fica mais evidente o papel dos choferes como acessórios de luxo que acompanham as máquinas (figura 17).

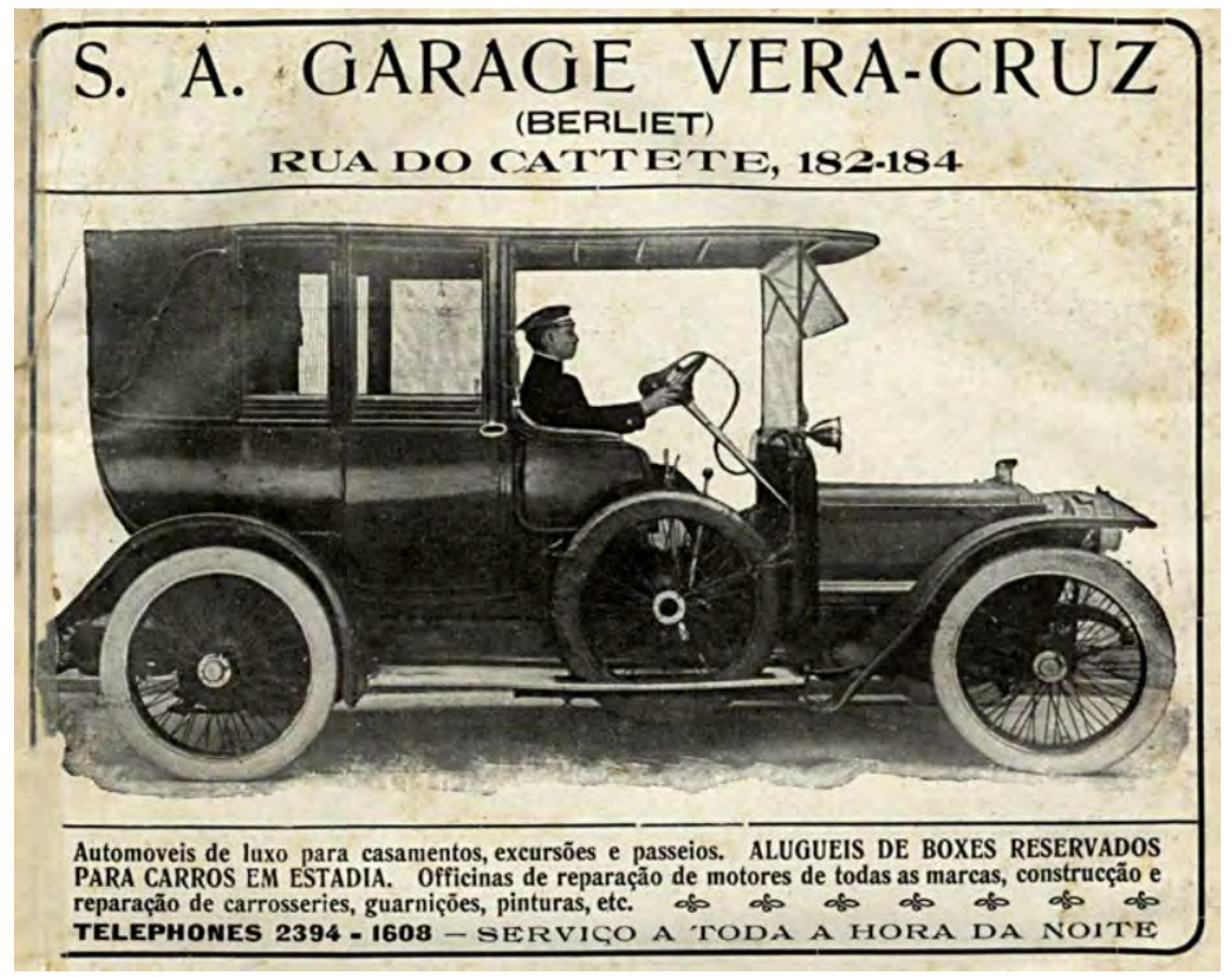

Figura 17 - Fon-Fon!. Rio de Janeiro, 01/01/1910, p. 5.

Esse tipo de aparição, marginal e puramente distintiva, ocorre também, por exemplo, no filme paulista Caça à raposa (Antonio Campos, 1913). O primeiro plano mostra um carro, um chofer e outros homens uniformizados nos jardins da abastada família Penteado. Olívia Guedes Penteado, organizadora da caçada da qual nunca vemos a presa, entra no automóvel, seguida de sua filha. Como comenta Eduardo Morettin em sua análise da obra, os "indícios de riqueza, como o carro, os funcionários, o cavalo, as vestimentas de equitação e o pequeno círculo social identificado pela maneira de se portar e vestir"' são estruturantes, constituindo os elementos da própria articulação entre os planos do

\footnotetext{
${ }^{39}$ Para se ter uma ideia, em 1906 “já havia 143 automóveis no Rio de Janeiro. Três anos antes, a Prefeitura licenciara apenas 6 carros.” (DUNTOP apud AZEVEDO, Artur. Teatro a Vapor - Organização, introdução e notas de Gerald M. Moser (do State College, Pensilvânia, EUA). São Paulo: Editora Cultrix, 1977, p. 79).
} 
filme. ${ }^{40}$ Outro caso em que um motorista cumpre a função de atestado de riqueza é Exemplo regenerador (José Medina, 1919), também realizado em São Paulo. Neste curta, o automóvel é o veículo que leva o protagonista, marido (que dá mais importância a supostas "conferências" que ao casamento) para longe da esposa. As ações do motorista se restringem a abrir e fechar a porta do automóvel para seu patrão passar, ações que são inclusive dispensadas quando o proprietário é tomado pelo ciúme e sai do veículo sem tempo de esperar pelos gestos servis de seu funcionário.

Em seu estudo sobre a presença de figuras populares no documentário silencioso brasileiro, Flavia Cesarino Costa chama a atenção para o lugar que os motoristas ocupam no teatro da elite política, ao comentar o filme $O$ príncipe herdeiro da Itália em terras do Brasil (Botelho Film, 1924). O filme mostra diversas atividades da visita do estrangeiro, que participa de eventos públicos, acompanhado de membros da elite local. Como ela observa, "durante todos os momentos de aparição do príncipe em locais públicos os populares ficam à distância, a não ser aqueles que ocupam posições serviçais, como o chofer do automóvel da comitiva." 41

Nos corsos, eventos paradigmáticos da exibição pública dessa elite que buscava associar-se às máquinas modernas, as câmeras fotográficas e cinematográficas estavam lá em função dos proprietários, é claro. Sendo passageiros desses autos conduzidos por seus motoristas, eram os ricos que faziam o papel de atores, posando para as objetivas. E, aos motoristas, restava o lugar de infiltrados na cena. Por meio de diferentes operações de identificação e distinção, vimos alguns elementos da construção da personagem do chofer no contexto carioca do início do século XX. Tal como aparece nas revistas ilustradas, ele se formou nas ambíguas relações que estabeleceu com outras figuras como pedestres, proprietários, passageiros e passageiras, repórteres, criados, policiais. A partir da análise de elementos da cultura visual da época, buscamos levantar algumas contradições próprias dessas relações, no sentido de construir o contexto e introduzir o clima desta dissertação.

\footnotetext{
${ }^{40}$ MORETTIN, Eduardo. Dimensões históricas do documentário brasileiro no período silencioso. Revista Brasileira de História. V. 25, No. 49. São Paulo, 2005, p. 143.

${ }^{41}$ COSTA, Flávia Cesarino. Figuras populares no documentário silencioso brasileiro. Imagofagia: Revista de la Asociación Argentina de Estudios de Cine y Audiovisual, No. 8, 2013, p. 8. Disponível em: < http://www.asaeca.org/imagofagia/index.php/imagofagia/article/view/493/421 >. Acesso em: 10/04/2018.
} 
E desta vez nossos dados nos mandaram para a casa número 30 no tabuleiro do Circuito de Fon-Fon (figura 18). A legenda diz: "Hospicio de Alienados. Passa a toda a velocidade... por causa das duvidas. Avança 5 casas."

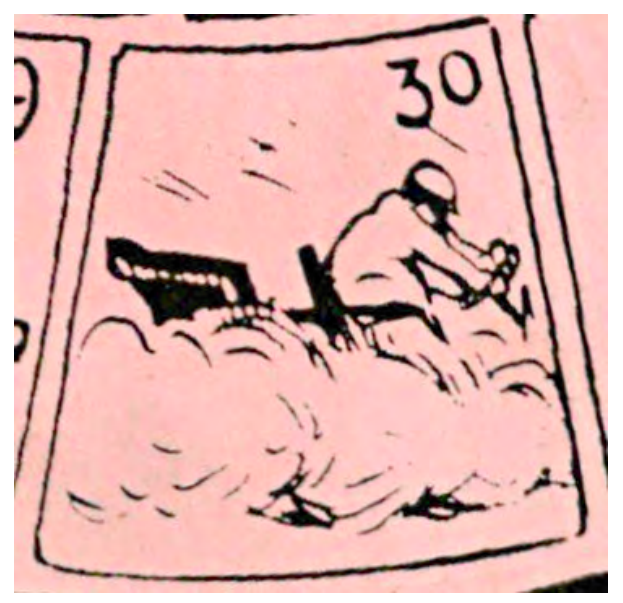

Figura 18 - Circuito de Fon-Fon. Fon-Fon!. Rio de Janeiro, 12/09/1908, p. 14-15, detalhe.

A ilustração mostra um automóvel quase todo coberto por fumaça, sinal da alta velocidade. Mesma velocidade que era a protagonista nas corridas de automóveis, que já há alguns anos aconteciam periodicamente na Europa e Estados Unidos e das quais chegavam ao Brasil notícias cada vez mais constantes. São Paulo já havia sediado uma, o Circuito de Itapecerica, em 1907, que foi inclusive cinematografado, ${ }^{42}$ o que permitiu que o carioca pudesse ter tomado contato com as imagens em movimento que dele capturaram.

No Rio de Janeiro, a primeira corrida aconteceu um ano depois da publicação de nosso jogo, em setembro de 1909, no município rural de São Gonçalo. Dois dias depois da realização do evento, imagens em movimento vêm somar-se ao conjunto de relatos e fotografias, que já povoavam a imprensa. O filme Circuito de São Gonçalo, também chamado de Corridas de automoveis em São Gonçalo, foi realizado a pedido do cinema Odeon. Tudo indica que o operador tenha sido Paulino Botelho. As imagens mostram panoramas dos espectadores agitados e da preparação dos pilotos antes da corrida começar; os carros na largada, durante o percurso e na linha de chegada. Em alguns planos, vemos as máquinas destruídas por acidentes no trajeto.

\footnotetext{
${ }^{42}$ Segundo a Filmografia Brasileira, o filme $O$ circuito de Itapecerica foi provavelmente produzido pela Photo-Cinematographia Brasileira e o operador teria sido Antônio Leal. O lançamento teria sido em 28 de julho de 1908, no Cinema Palace do Rio de Janeiro.
} 
Quando o cinematógrafo e o automóvel se uniram na construção daquele espetáculo, evidenciou-se a capacidade do cinema em registrar a velocidade da vida moderna. Os dois estiveram, a partir de meados da primeira década do século $\mathrm{XX}$, a serviço da elite carioca, que buscava ser identificada com os símbolos da modernidade, importados dos países centrais. A máquina significou, para alguns, aqueles que tinham o direito à representação, o prestígio da associação com uma modernidade pretendida, que combinava excitação e perigo. $\mathrm{O}$ filme foi instrumento daquela elite que, ao colocar seus automóveis importados e caríssimos em risco, buscou distinguir-se daqueles que eram pedestres na cena urbana. O primeiro capítulo tem como objeto o filme de 1909. A análise de suas imagens remanescentes, em diálogo com outros filmes estrangeiros do tipo, busca evidenciar relações entre atração e acidente.

Se os dados por acaso nos levarem à casa número 16 do nosso tabuleiro de FonFon!, veremos uma imagem estranha (figura 20).

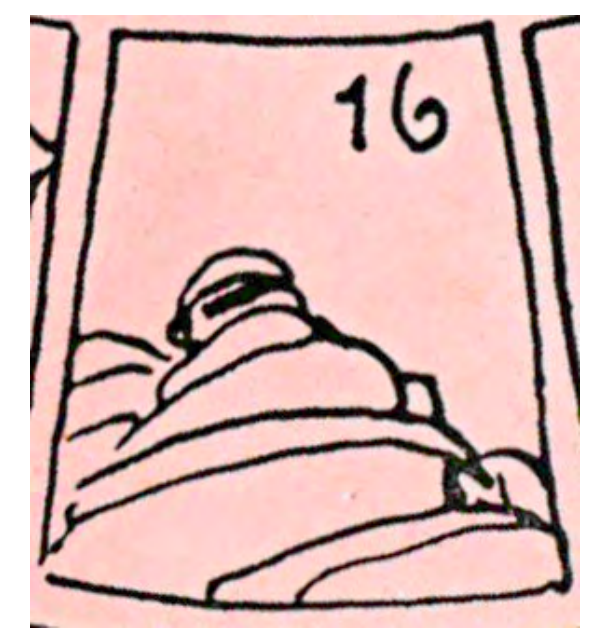

Figura 20 - Circuito de Fon-Fon. Fon-Fon!. Rio de Janeiro, 12/09/1908, p. 14-15, detalhe.

O desenho representa um motorista de costas e os bancos de um automóvel, vistos por trás. Nosso ponto de vista quase coincide com o do condutor. Se o operador cinematográfico coloca sua câmera dentro do próprio veículo em movimento, ou seja, quando o operador tem o mesmo ponto de vista do chofer, a imagem resultante é um travelling. Esse tipo de plano, muito popular no primeiro cinema, podemos chamar filme de viagem fantasma. ${ }^{43} \mathrm{O}$ gênero surgiu já no final do século XIX e era produzido a partir

\footnotetext{
${ }^{43}$ Em inglês, phantom ride film. Cf. RABNOVITZ, Lauren. Phantom train rides. ABEL, Richard (Ed.). Encyclopedia of early cinema. New York: Routledge, 2005, p. 514-515.
} 
da dianteira ou traseira de veículos em movimento, principalmente trens, mas também carros. A relação entre o espectador e o passageiro, no primeiro cinema, tem expressão radical nos simuladores cinematográficos de viagem, que surgiram em 1905 em um parque de diversões norte-americano, com os Hale's Tours and Scenes of the World, salas de cinema que imitavam o interior de vagões de trem. Os filmes de viagem fantasma (e de outros gêneros ligados a temas de viagem) eram acompanhados pelo balanço dos assentos, efeitos sonoros e ventiladores que simulavam o vento que uma viagem real de trem produziria no interior de um vagão.

O sucesso foi tão grande que a atração se espalhou pelo mundo, simulando inclusive passeios de automóveis, como foi o caso no Brasil, com os Auto-Tours. Eles seguiam a tradição dos panoramas que utilizavam telas pintadas para dar a impressão, no espectador, de estar tomando parte em uma viagem por lugares distantes. Ao contrário do que ocorria nos Hale's Tours norte-americanos, que eram predominantemente frequentados por trabalhadores, os simuladores de viagem cariocas participaram da tentativa de "elevação" da sala de cinema a um espaço "digno" da presença da elite. O segundo capítulo apresenta um mapeamento dos simuladores cinematográficos de viagem cariocas, relacionando-os às experiências de outras cidades brasileiras. Essas atrações são entendidas como um cenário no qual os espectadores agiam como atores de uma encenação proposta pelo próprio aparelho.

Depois de correr pelas ruas da cidade em alta velocidade, causar terror e acidentes, ver, ser visto e olhar o mundo do ponto de vista do próprio automóvel, nosso jogo vai chegando ao fim. O Circuito de Fon-Fon! nos sugeriu percursos para conhecer diferentes personagens envolvidas na relação que a elite carioca estabeleceu com essas duas máquinas modernas, o cinema e o automóvel. E não é à toa que o ponto de chegada é um edifício da Exposição Nacional Comemorativa do $1^{\circ}$ Centenário da Abertura dos Portos do Brasil de 1908 (figura 20). 


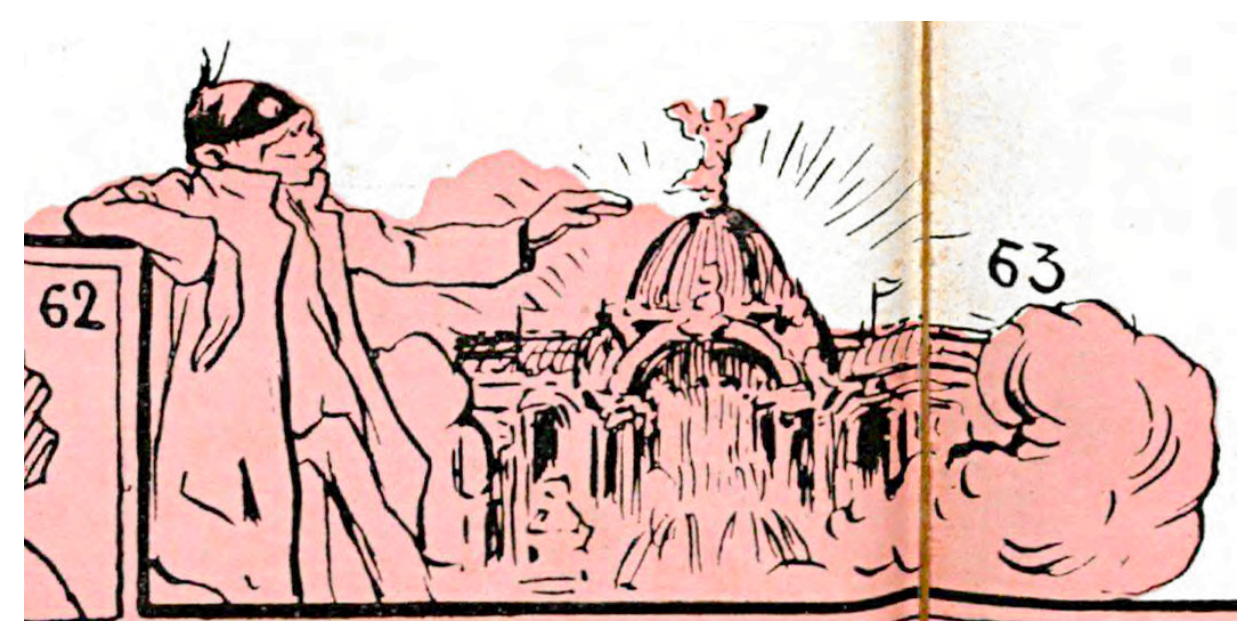

Figura 20 - Circuito de Fon-Fon. Fon-Fon!. Rio de Janeiro, 12/09/1908, p. 14-15, detalhe.

A Exposição, de modo análogo ao próprio jogo e aos simuladores cinematográficos, buscava fazer o visitante sentir-se parte de um Brasil cosmopolita, por meio da reprodução em miniatura de uma versão idealizada do país.

Por cerca de três meses, a exposição recebeu mais de um milhão de visitantes mediante pagamento de ingresso. Instalada no bairro da Urca, na zona sul da cidade, contou com diversos edifícios luxuosos, construídos para a ocasião, que representavam cada um dos estados brasileiros, e de um dedicado a Portugal. Dentro dos pavilhões, foram expostos objetos os mais diversos, como obras de arte, produtos da indústria brasileira e novas invenções. Aquele espaço apresentou a própria cidade como um cenário, no qual os membros da elite, protegidos por seus muros, exibiram-se de diferentes formas.

Alguns filmes foram realizados no recinto, todos perdidos. Entre eles, Sô Lotero e nhá Ofrasia com seus productos na Exposição, filme que provavelmente combinou ficção e atualidade ao mostrar a visita de um casal de caipiras ao evento. No terceiro capítulo, a partir de pesquisa documental brasileira e estrangeira, de época e posterior, fílmica e não fílmica, buscamos sugerir um percurso possível para este encontro entre personagem ingênua e o universo cosmopolita da capital, que condensa tanto o fascínio ligado aos signos da modernidade quanto a ansiedade provocada por eles. 


\section{Primeiro capítulo}

\section{Circuito de São Gonçalo (Empresa F. Serrador, 1909): a iminência do acidente automobilístico como espetáculo moderno}

- Ó mamãe, o que é circuito? - É uma porção de gallinhas mortas, meu filho. ${ }^{44}$

\section{A elite sobre rodas}

No dia 19 de setembro de 1909, nas estradas de terra de um pequeno município do estado do Rio de Janeiro, uma multidão assistiu a um espetáculo protagonizado pela velocidade e seus possíveis efeitos catastróficos. Era o Circuito de São Gonçalo, segunda corrida automobilística organizada pelo recém-fundado Automóvel Clube do Brasil. ${ }^{45} \mathrm{O}$ evento foi largamente noticiado por jornais e revistas cariocas, que estamparam algumas de suas páginas com fotografias que davam a ver diferentes aspectos da competição, incluindo a aparência dos carros acidentados. Logo depois da realização do evento, imagens em movimento somaram-se ao conjunto de relatos e fotografias que já povoavam a imprensa. O filme Circuito de São Gonçalo (Empresa F. Serrador, 1909), lançado apenas dois dias depois da corrida, foi exibido repetidas vezes em diversas salas de cinema no Rio de Janeiro e em outras cidades nas semanas seguintes. O filme, nosso objeto de análise neste primeiro capítulo, mostra os competidores em alta velocidade e a plateia repleta de membros da chamada alta sociedade carioca. Apesar das imagens remanescentes não mostrarem nenhum acidente no exato momento em que ocorria, uma sequência chama a atenção para o perigo que a corrida representou: são planos de carros que quase atropelam animais que atravessam a pista e de automóveis amassados pelas batidas. O encontro entre automóvel e cinema, quando apropriado pela elite da Belle Époque carioca, aponta tanto para a exibição pública dos ricos e poderosos associados a

\footnotetext{
${ }^{44}$ Fon-Fon!. Rio de Janeiro, 25/09/1909, p. 14.

45 O A.C.B. foi fundado em 27 de setembro de 1907 por Santos Dumont, José do Patrocínio, Álvaro Fernandes da Costa Braga, Aarão Reis, Olavo Bilac e Fernando Guerra Durval. A primeira corrida organizada pelo clube foi o Circuito de Itapecerica, que aconteceu em São Paulo no dia 26 de julho de 1908, em parceria com o Automóvel Clube de São Paulo, fundado 11 dias antes da competição.
} 
essas duas máquinas modernas, quanto para a excitação sensorial que este encontro é capaz de provocar.

Quase todos os artigos publicados na imprensa sobre o evento, tanto antes como depois de sua realização, enfatizaram os perigos implicados em uma corrida de automóveis. Das quatro páginas que a revista Careta dedicou a ela, por exemplo, uma foi integralmente ocupada por uma montagem que mostrava dois automóveis batidos em primeiro plano (figura 21).

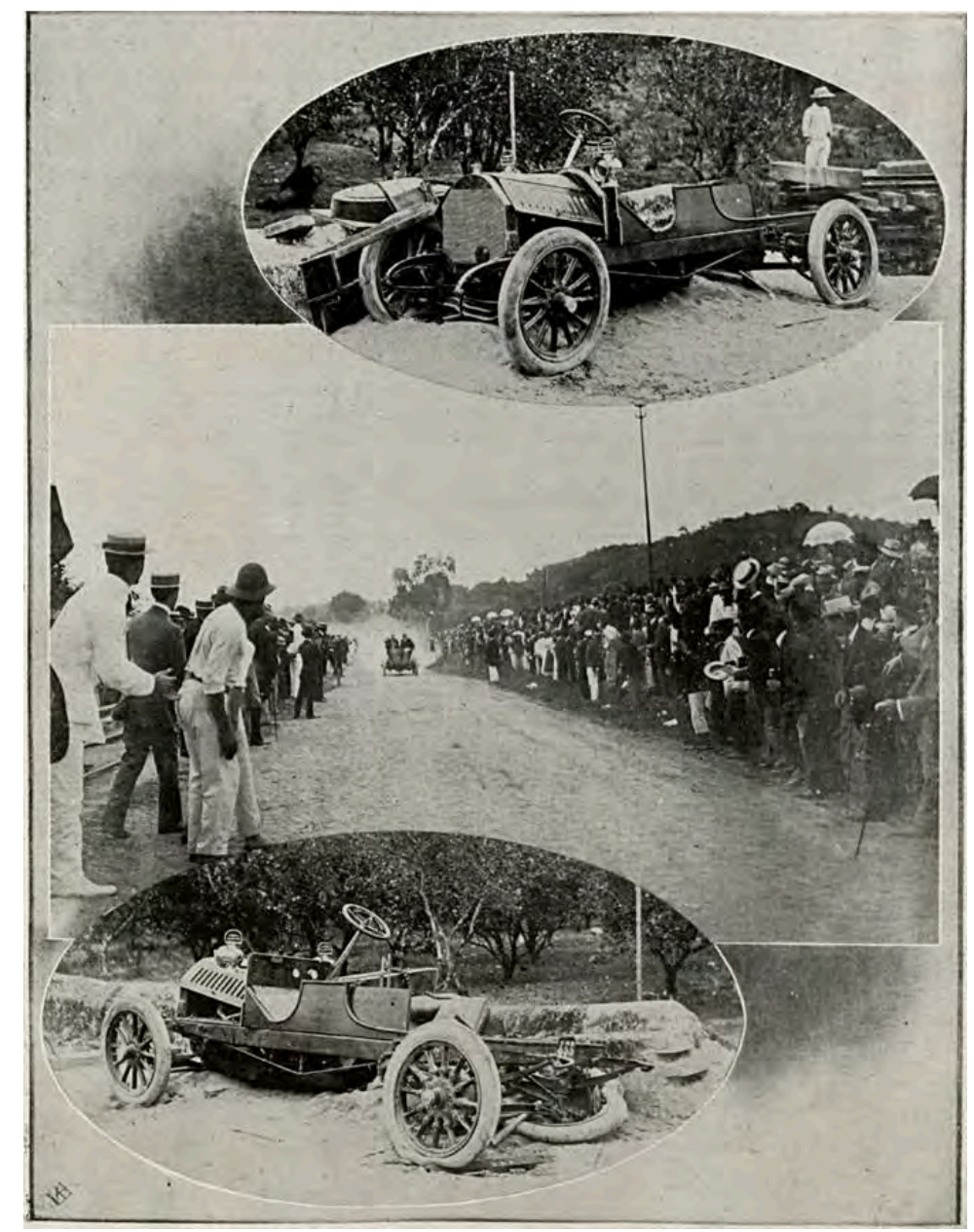

Figura 21 - Careta. Rio de Janeiro, 25/09/1909, p. 13.

Nas outras páginas, vêem-se fotografias das arquibancadas, nas quais é possível distinguir alguns membros da elite política do Rio de Janeiro. Já o jornal Gazeta de Notícias, que ocupou um terço da capa da edição do dia seguinte à realização da corrida com uma matéria a respeito, publicou três fotografias: uma da plateia, uma do veículo vencedor e uma que mostra um carro aparentemente inteiro (em um registro provavelmente anterior 
à largada). Esta última, no centro da página, é complementada por uma legenda que diz que o automóvel teria sido "victima de um accidente, rebentando a caixa de gazolina". 46

Grande parte das reportagens publicadas antes do dia 19 de setembro descreve em detalhes as ações que as autoridades planejaram para "evitar possíveis desastres". 47 Dentre as precauções adotadas, nos locais por onde passariam os carros, o trânsito de outros veículos foi interrompido e o de pedestres, desaconselhado. ${ }^{48}$ Como esperava-se um grande público, o número de barcas e bondes foi aumentado para "facilitar o transporte dos sportmen" 49 do Rio de Janeiro até São Gonçalo, cidade que sediou o evento, do outro lado da Baía de Guanabara. Mas a quantidade de espectadores que realmente compareceu mesmo sem ter comprado ingressos superou as expectativas e parece ter dificultado os planos da polícia para manter as pessoas nas arquibancadas (uma reportagem contou um total de 5.000 pessoas). ${ }^{50}$ Estas, feitas em madeira, ao ar livre, foram especialmente construídas para a ocasião. Eram divididas em "camarotes", que custavam 25.000 réis, valor equivalente aos mais caros assentos teatrais, e "gerais", que custavam 3.000 réis, três vezes mais do que costumava-se pagar para ir ao cinema. Pagando 1.000 réis, o público tinha acesso ao local onde os automóveis competidores foram pesados antes da corrida. ${ }^{51} \mathrm{~A}$ arquibancada parece ter sido um espaço privilegiado de onde os membros da elite puderam não só ver a partida e a chegada dos veículos, mas também ser vistos em destaque, tanto por seus pares, como pelas lentes fotográficas e cinematográficas.

Só podiam tomar parte da corrida "como conductores, os socios do Automovel Club do Brasil, Automovel Club de S. Paulo e Amadores, isto é, pessoas que não sejam profissionaes ou mechanicos assalariados." ${ }^{25}$ A diferenciação entre automobilistas profissionais e amadores aparece aqui como sinal do elitismo da corrida. Dos dezesseis inscritos, foram onze os competidores presentes, além de seus mecânicos assistentes (raramente nomeados). Da primeira categoria, com os veículos mais velozes, participaram quatro competidores: Jorge Haentjens, João Borges Junior, Francisco Cunha Bueno Netto e Gastão Ferreira de Almeida. Este último, que ganhou a corrida, realizou o

\footnotetext{
${ }^{46}$ CORRIDA de automoveis. Gazeta de Notícias. Rio de Janeiro, 20/09/1909, p. 1.

${ }^{47}$ CORRIDA de automoveis. A Imprensa. Rio de Janeiro, 08/10/1909, p. 4.

${ }^{48}$ Ibidem.

${ }^{49}$ CORRIDA de automoveis. Correio da Manhã. Rio de Janeiro, 19/09/1909, p. 4.

${ }^{50} \mathrm{O}$ que talvez seja exagero, mas diz algo sobre a dimensão da multidão que compareceu ao evento. CORRIDA de automoveis. Gazeta de Notícias. Rio de Janeiro, 20/10/1909, p. 1.

${ }^{51}$ CORRIDA de automoveis (Circuito de S. Gonçalo). Gazeta de Notícias. Rio de Janeiro, 18/09/1909, p. 6.

${ }^{52}$ AUTOMOBILISMO. Correio da Manhã. Rio de Janeiro, 31/07/1909, p. 5.
} 
percurso de 72 quilômetros em uma hora e quatro minutos. A segunda categoria foi composta por Raul J. das Chagas, Charles Meyer, C. Bozisio e Francisco Serrador. O último, um espanhol de nome muito conhecido na história do cinema brasileiro antigo por ter sido responsável pela inauguração da primeira sala regular de São Paulo em 1907, o Bijou, e pela formação da Cinelândia no Rio de Janeiro nos anos 1920. Voltaremos adiante à relação de Serrador com a produção do filme Circuito de São Gonçalo. As outras duas categorias foram compostas por José d'Orey, Raul Berroguin e Avelino ${ }^{53}$ Berroguin. ${ }^{54}$ Os principais prêmios, as taças "Estado do Rio", ofertada pelo presidente do Estado, Alfredo Backer, e "Visconde de Moraes", cedida por este capitalista que participou da organização do evento, foram expostas em duas lojas nos dias que antecederam o raid automobilístico, na ourivesaria Moreira, à rua do Ouvidor, e na casa Rezende, respectivamente.

O clube de amantes do automóvel tentou por três vezes realizar uma competição no Rio de Janeiro. Primeiro na Avenida Beira-Mar, depois da Gávea à Tijuca: ambas as opções foram negadas pela polícia, provavelmente por conta do perigo que representaria para a população. ${ }^{55}$ São Gonçalo, um município predominantemente rural, foi então escolhido e finalmente aprovado. Algumas semanas antes, um grupo de associados visitou o local para analisar as condições da pista. Uma reportagem na Gazeta de Notícias sugere o que significou a corrida para a pequena cidade:

\footnotetext{
(...) desembarcaram muitos automoveis, conduzindo todos elles, passageiros equipados como para uma corrida: guardas-pó, oculos, vizeiras, etc. (...) Todos esses autos, após uma pequena demora na praça da estação [de Niterói], tomaram a mesma direcção, encaminhando-se para as Neves [local escolhido como ponto de partida e chegada da corrida] e com os escapamentos abertos e o businar continuo das suas trompas, davam ás ruas que percorriam, uma nota alegre e de festa, chamando ás janellas os habitantes entregues ao dominical repouso. $^{56}$
}

O encontro de diferentes realidades é significativo: membros da elite carioca, montados em suas máquinas barulhentas, vestidos de modo esportivo, tomam conta das ruas pacatas de uma cidadezinha em pleno domingo, enquanto os moradores assistem à caravana, que

\footnotetext{
${ }^{53}$ Em algumas notícias, este aparece como Honório.

${ }^{54}$ Desses nomes, dois participaram do Circuito de Itapecerica, corrida realizada em São Paulo no ano anterior: Jorge Haentjens e Gastão de Almeida. Haentjens foi o primeiro a largar. Almeida era o favorito perto da linha de chegada, com 5 minutos de vantagem sobre os outros competidores de sua categoria. Mas, por conta de um reservatório de óleo caído, acabou ficando em segundo lugar na corrida paulista. ${ }_{55}$ CORRIDA de automoveis: circuito de S. Gonçalo. A Capital. Niterói, 20/09/1909, p. 1.

${ }^{56}$ AUTOMOBILISMO: ensaios para o grande circuito. Gazeta de Notícias. Rio de Janeiro, 04/09/1909, p. 6.
} 
já anunciava o que estava por vir nas próximas semanas. O tom festivo deriva do fato de que o autor dessas linhas era parte do grupo motorizado. A estrada foi então reformada para a realização da competição. Mesmo assim, muitas reportagens associavam o perigo da corrida às más condições da pista, que, comparada às da Europa, tinha muita areia. ${ }^{57}$

Não era só no contexto de competições que os acidentes eram tematizados na imprensa. As batidas e atropelamentos automobilísticos tornavam-se parte do próprio cotidiano da cidade naquele momento. A partir de 1906, são cada vez mais frequentes as notícias sobre desastres (chegando a serem quase diárias por volta de 1909), ocupando os jornais com descrições macabras, quase sempre acompanhadas de reclamações direcionadas aos motoristas e às autoridades. ${ }^{58}$ Ainda antes da visita dos associados a São Gonçalo, o perigo da realização de uma corrida já se apresentou concretamente nas ruas da capital federal, com o treino dos competidores, como reclama um jornalista em $A$ Notícia: "Nós temos machinas de corridas percorrendo os pontos mais frequentados, e ha dias, quando foi do circuito de São Gonçalo, os automoveis fizeram exercicios preliminares na Avenida Beira-Mar, desenvolvendo até $120 \mathrm{k}$. á hora!". 59 Muito se discutia, naquela época, a respeito de parâmetros de punição para os excessos dos motoristas e não havia ainda um limite de velocidade estabelecido por lei. Como lembra Nicolau Sevcenko, os carros chegaram ao Brasil

\footnotetext{
antes que existissem uma estrutura viária, sinalização ou códigos de trânsito, gerando uma situação calamitosa, agravada pelo fato de que atropelamentos, mesmo seguidos da morte das vítimas, eram apenas passíveis de uma multa pecuniária de valor ínfimo para os infratores. Era o convite para o terrorismo automotor que veio para ficar, acrescentando tonalidades mecânicas aos sistemas de privilégios e opressão típicos da sociedade brasileira. ${ }^{60}$
}

Os acidentes decorrentes da própria corrida não foram considerados graves, mas, ainda assim, ganharam especial atenção da imprensa. Quase todas as reportagens posteriores ao evento contavam com uma seção sobre o assunto. Um participante teve

\footnotetext{
${ }^{57}$ Gostaríamos de chamar atenção para este motivo, que reaparecerá diversas vezes ao longo do capítulo, em forma de poeira da pista, pó levantado pelos veículos, fumaça do motor ou de explosões.

58 Passam a ser cada vez mais frequentes, nos jornais, frases como: "A mania do automobilismo tem produzido já bastantes e consideraveis desastres.” (O Malho. Rio de Janeiro, 30/07/1904, p. 20), ou: “O dia frio acordou calmo para a policia. (...) Nem um bom escandalosinho (...), nem um desastre de automovel! Decididamente o reino dos reporteres extinguio-se." (A POLICIA pela manhã. A Notícia. Rio de Janeiro, 25/05/1911, p. 1), ou ainda: "Raro é o dia em que não tenhamos de registrar um desastre de automovel." (AUTOMOVEL que vira. A Notícia. Rio de Janeiro, 05/11/1912, p. 2).

${ }^{59}$ ECHOS. A Notícia. Rio de Janeiro, 27/10/1909, p. 1.

${ }^{60}$ SEVCENKO, Nicolau. A capital irradiante: técnica, ritmos e ritos do Rio. In: NOVAIS, Fernando A. (Coordenador-geral); SEVCENKO, Nicolau (Org.). História da vida privada no Brasil. República: da Belle Époque à Era do Rádio. Vol. 3. São Paulo: Companhia das Letras, 1998, p. 558.
} 
três pneus furados, outro terminou a prova com a carroceria queimada e um rombo no tanque de gasolina. Outro concorrente teve seu carro partido numa queda, joelhos e cabeça arranhados e o mecânico que o acompanhava foi arremessado para fora do veículo, ferindo uma das pernas. ${ }^{61}$ Todos esses estragos e ferimentos são descritos em diversos jornais depois do circuito.

Como advertiu uma nota publicada um dia antes da corrida, "fóra do recinto fechado das archibancadas não [era] permitida a permanência do publico, por ordem da policia, afim de evitar desastre." ${ }^{, 62}$ As batidas, previstas pela ordem, parecem ter sido ansiadas pelo público, como nos faz suspeitar uma descrição do comportamento da massa presente no evento: segundo a Gazeta de Notícias, os curiosos aglomeraram-se em um ponto do trajeto, "um dos mais perigosos para os intrepidos automobilistas", "para assistir daquelle ponto, (...) á passagem dos autos". O mesmo artigo enfatiza que "os commentarios sobre desagradaveis sucessos choviam". ${ }^{63}$ As autoridades certamente se preocuparam muito com os possíveis acidentes automobilísticos, mas não previram a dimensão da multidão, que, desobedecendo as indicações policiais, escorreu pelas margens das estradas de terra que serviram de pista para a competição em busca de um outro tipo de visão privilegiada.

O comportamento dos espectadores e a forte presença, nas reportagens relacionadas ao Circuito de São Gonçalo, de descrições tanto da prevenção de possíveis desgraças, como dos desastres efetivamente ocorridos, apontam para uma indissociação entre velocidade e acidente: a atração do espetáculo esteve não só na rapidez das máquinas, mas também em como essa mesma rapidez sugeria seu potencial destrutivo. Indissociação esta que será essencial para a compreensão de nosso filme.

\section{Cinema da localidade}

Em nota publicada n'O Paiz de 21 de setembro de 1909, lê-se:

\footnotetext{
Além do esplendido programma novo, o Odéon exhibe hoje, á noite, uma linda fita, reproduzindo clara e fielmente todas as peripecias do circuito de $\mathrm{S}$. Gonçalo, realizado domingo. Três operadores apanharam, com a maxima felicidade, essa corrida de automoveis de sensação, sendo elles das casas Marc
}

\footnotetext{
${ }^{61}$ CORRIDA de automoveis. Gazeta de Notícias. Rio de Janeiro, 20/10/1909, p. 1.

${ }^{62}$ Ibidem.

${ }^{63}$ Ibidem.
} 
Ferrez, Vallé e Eclypse. Como se vê, o Odéon não perde occasião de bem servir o publico, que enche diariamente os seus ricos salões. ${ }^{64}$

O filme foi exibido em algumas das salas consideradas mais elegantes do Rio, os cinemas Odeon e Ouvidor, e também em São Paulo, no Bijou. ${ }^{65}$ Foi divulgado como "grande e completo exito da cinematographia brasileira" 66 e foi exibido frequentemente como última ou penúltima atração, junto com outros 5 filmes. Segundo Jurandyr Noronha, o operador foi Paulino Botelho ${ }^{67}$ que, com seu irmão Alberto, produziam para o Odeon. Na época da corrida, Serrador já era produtor cinematográfico, proprietário de salas de cinema e teatro e representante da empresa cinematográfica francesa Pathé Frères no estado de São Paulo. ${ }^{68}$ Como assistente, correu com ele o cinegrafista Alberto, no carro de número 10. Paulino, o irmão mais velho de Alberto, teria sido então o responsável pela captação das imagens em movimento. ${ }^{69} \mathrm{O}$ carro deles foi um dos acidentados que, como descreve uma notícia, "incendiou os motores, ficando seu conductor com uma das mãos ligeiramente queimada". ${ }^{70}$

Ao que tudo indica, não restou nenhuma cópia do filme em película. $\mathrm{O}$ acesso que temos a ele por enquanto é por meio do documentário 70 anos de Brasil: da Belle Époque aos nossos dias (Jurandyr Noronha, 1972), cujas cópias analógicas, apesar de existirem,

\footnotetext{
${ }^{64}$ CINEMA Odéon. O Paiz. Rio de Janeiro, 21/09/1909, p. 6.

${ }^{65}$ BERNARDET, Jean-Claude. Circuito de São Gonçalo 1909-43. Filmografia do cinema brasileiro 19001935: Jornal o Estado de S. Paulo (levantamento feito por Jean-Claude Bernardet). São Paulo: Secretaria de Cultura, Comissão de Cinema, 1979, s. p.

${ }^{66}$ Conforme anúncio publicado em Jornal do Commercio. Rio de Janeiro, 24/09/1909 p. 20, entre outros exemplos.

${ }^{67}$ NORONHA, Jurandyr. No tempo da manivela. Rio de Janeiro: Editora Brasil-América (Ebal); Kinart Cinema e Televisão; Embrafilme, 1987, p. 16.

${ }^{68}$ Quem detinha o controle do fornecimento de filmes e equipamentos da Pathé no Brasil, naquele momento, era a empresa Marc Ferrez \& Filhos, administrada pelos "filhos do mais renomado fotógrafo do Segundo Império e netos de um dos artistas da Missão Francesa de 1816" (MORAES, Julio Lucchesi. O magnata de Valência: capitalistas, bicheiros e comerciantes do primeiro cinema no Brasil (1904-1921). Revista Movimento, n. 1, junho 2012. São Paulo, p. 14.). Serrador era subordinado àquela empresa. A situação muda bastante alguns anos depois com o rompimento de Serrador e os Ferrez. (Cf. MORAES, Julio Lucchesi. Notas para uma história econômica do cinema brasileiro: o caso da firma Marc Ferrez \& Filhos. Revista da Cinemateca Brasileira, n. 2, fevereiro 2013. São Paulo, pp. 25-39.)

${ }^{69}$ Há divergências quanto à produção do filme Circuito de São Gonçalo na bibliografia. Vicente de Paula Araújo atribui a autoria do filme a Alberto. Segundo o levantamento de Jean-Claude Bernardet, o produtor teria sido Francisco Serrador e o operador, Alberto novamente (o que não seria possível, já que, segundo os jornais da época, este participou da corrida como assistente de Serrador). Já a narrativa de Jurandyr Noronha conta que a produção teria sido da Botelho Filmes, empresa dos irmãos Botelho, e que teria sido Paulino o operador cinematográfico. (Cf. ARAÚJO, Vicente de Paula. Salões, circos e cinemas de São Paulo. São Paulo: Editora Perspectiva, 1981, p. 177; BERNARDET, Jean-Claude. Op. cit.; NORONHA, Jurandyr. Op. cit., p. 16.) Sabemos que desde 1908 os três trabalhavam juntos. Parece-nos acertado afirmar que Serrador esteve envolvido na produção e que Paulino foi o operador, já que Alberto exercia outra função no evento.

${ }^{70}$ CORRIDA de automoveis. Gazeta de Notícias. Rio de Janeiro, 20/10/1909, p. 1.
} 
estão indisponíveis no momento, o que impede seu visionamento. ${ }^{71} \mathrm{O}$ que resta das imagens, provavelmente as mais antigas do cinema brasileiro que ainda podemos ver hoje, são aquelas que Noronha incorporou em seu filme, ao qual temos acesso apenas por cópia em DVD. ${ }^{72}$

Tomando-o tal como aparece no documentário de Jurandyr Noronha, o filme Circuito de São Gonçalo tem três minutos de duração e é composto por 23 planos. Podemos dividir o curta em três partes: a primeira, que dura cerca de 1 minuto e é formada por seis planos, mostra os preparativos da corrida e o público; a segunda, que dura cerca de 40 segundos e tem sete planos, mostra diferentes pontos da pista por quais passam os carros competidores; a terceira, que dura um pouco mais de 1 minuto e tem dez planos, trata dos perigos do percurso e outros aspectos como o ponto de parada para reparos dos automóveis. O filme termina com a chegada de um dos carros ao ponto final do trajeto, correndo por uma multidão que abre passagem.

70 anos de Brasil: da Belle Époque aos nossos dias, chamado por seu autor de "filme-antologia",73 reúne diversos trechos de filmes brasileiros documentais, além de fotografias e imagens de revistas ilustradas, apresentados de modo cronológico. Uma narração dá sentido ao conjunto, enfatizando datas e eventos cívicos. Como já sugere sua cartela inicial, ${ }^{74}$ a produção cinematográfica brasileira é valorizada na obra enquanto registro histórico nacional. As imagens de Circuito de São Gonçalo, que analisaremos a seguir, aparecem no início do longa, depois de cerca de 3 minutos de seu início (de um total de cerca de 1 hora e 9 minutos de duração). Em um procedimento que se repetirá inúmeras vezes ao longo do filme, de comparação da história europeia com a brasileira, o narrador comenta as corridas de automóveis "na Europa" (vemos um homem empurrar um carro em uma estrada de terra enquanto outras pessoas caminham) ${ }^{75}$ para depois apresentar o que ocorria “em nosso país” (é a partir daí que vemos as imagens de Circuito de São Gonçalo). Durante todo o trecho, a voz over simula uma narração da corrida, oferecendo diversos dados sobre o evento. Logo depois das imagens de Circuito...,

\footnotetext{
${ }^{71}$ A Cinemateca Brasileira possui uma cópia. Quando fizemos o pedido de visionamento, fomos informados de que não havia recursos técnicos ou humanos para o atendimento.

72 A cópia que utilizamos é proveniente da Cinemateca do Museu de Arte Moderna do Rio de Janeiro. Agradecemos ao pesquisador Hernani Heffner pelo envio da cópia e por todo o seu auxílio e incentivo durante esta pesquisa.

${ }^{73}$ NORONHA, Jurandyr. No tempo da manivela. Rio de Janeiro: Editora Brasil-América (Ebal); Kinart Cinema e Televisão; Embrafilme, 1987, p. 112.

${ }^{74}$ Uma citação atribuída a Mário de Andrade: "O cinema é a criação mais representativa de nossa época. É preciso aproveitar-lhe a lição."

${ }^{75}$ A narração e a montagem sugerem que este plano seja de um filme estrangeiro. Por isso não a incluimos na análise.
} 
aparece a fotografia de um homem acidentado, sendo socorrido por uma ambulância motorizada. O narrador diz que, naquele ano, começavam os atropelamentos no então distrito federal, que já contava 3.000 automóveis em circulação. Ao longo de todo o filme de Noronha, muitas serão as imagens de automóveis (em cenas de rua e corsos carnavalescos), mas também de outros veículos como bondes, trens e aviões. Outra corrida de carros também aparece, mais adiante. É o Circuito da Gávea de 1933, conhecido pelo apelido sugestivo de "trampolim do diabo", como informa o narrador. Ao final, 70 anos de Brasil... apresenta uma série de retratos de cinegrafistas, responsáveis pelo registro histórico valorizado por Noronha. E, curiosamente, o filme termina com uma imagem impactante: é o último plano filmado pelo operador Ortiz Rúbio Alexim, da TV Tupi, em 1958, no momento de sua morte. Vemos quatro aviões que avançam em nossa direção, enquanto a narração explica que o homem que registrou aquela imagem, “à procura de um melhor ângulo, perde[u] a vida porque filmou a morte". É quando a asa de um dos aviões atinge a câmera e a imagem fica paralisada mostrando um grande borrão.

Apesar do conjunto de planos de Circuito... ter uma coerência (cronológica), não é improvável que, já no início dos anos 1970, uma parte do filme sobre São Gonçalo estivesse perdida. Também não é improvável que Noronha tenha feito alguma intervenção no material, como cortes de planos inteiros ou partes de planos para encurtar o trecho reproduzido em seu longa-metragem. Não encontramos nenhuma referência à metragem original do filme. Suspeitamos que, como a maior parte das produções do período, Circuito de São Gonçalo fosse composto por um rolo de película de cerca de 300 metros, que, quando projetado, teria a duração de cerca de 10 minutos.

O curta então começa com uma panorâmica que nos apresenta as personagens do espetáculo, no que parece ser um momento anterior ao início da corrida: homens e mulheres circulam entre aqueles que foram os protagonistas do show, os automóveis. Eles vestem ternos escuros, boinas, bengalas, chapéus coco ou de palha; elas, com seus enormes chapéus, usam vestidos claros e tem as sombrinhas sempre à mão. Algumas aparecem dentro dos carros estacionados, de pé. A aproximação estabelecida nesta cena entre mulheres e automóveis é uma das associações que, segundo Sevcenko, "assinalaria[m] em definitivo o destino mitológico do automóvel, tornando-o a base da vaidade masculina" ${ }^{76}$ Isso não se repetirá ao longo do curta, já que são apenas os homens os condutores dos volantes. É possível contar nos dedos as pessoas negras em quadro,

\footnotetext{
${ }^{76}$ SEVCENKO, Nicolau. A capital irradiante: técnica, ritmos e ritos do Rio. In: História da vida privada (v. 3) - República: da Belle Époque à Era do Rádio. São Paulo: Cia. das Letras, 1998, p. 558.
} 
comumente em mangas de camisa. As máquinas destoam do fundo, uma paisagem rural com construções modestas. Está claro que estamos diante de um espetáculo feito para a elite.

As imagens reforçam os relatos sobre a enorme multidão que acompanhou o evento. Uma moça sentada à nossa direita lança olhares para a aglomeração através de um binóculo (figura 22).

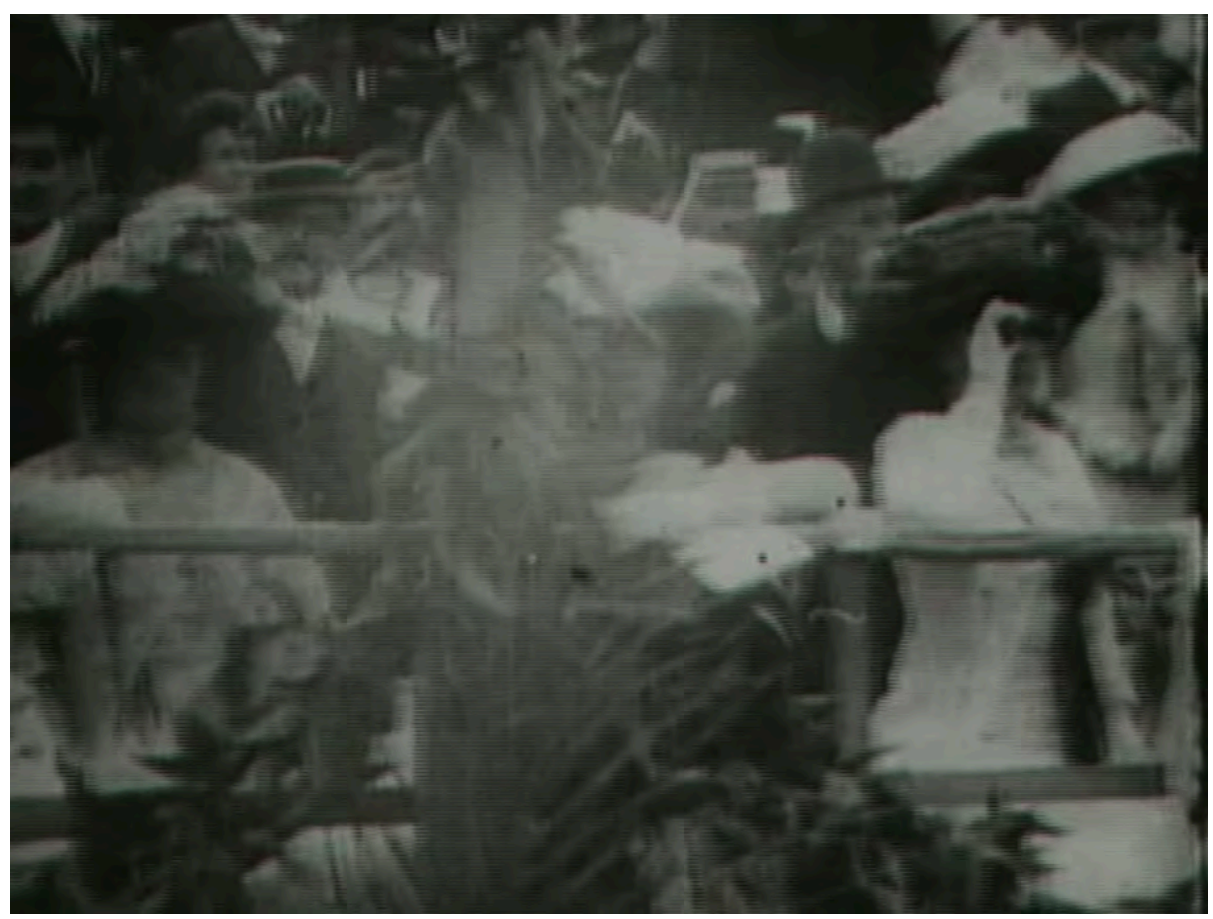

Figura 22 - Circuito de São Gonçalo (1909).

O instrumento óptico, que permite a observação de porções da paisagem difíceis ou impossíveis de ver sem ele, já era um velho conhecido das plateias nas óperas. O gesto da mulher, de escolher e focalizar detalhes da cena, espelha a produção do próprio filme, que serviu de palco para a exibição dessa elite. Muito comum durante as primeiras décadas do cinema, esse tipo de filme, chamado de "local", consistia na "audiência pagar para ver seus amigos, vizinhos, locais ou a si mesmos no cinematógrafo", 77 conforme explica Vanessa Toulmin. Ela acrescenta que o filme local pode abranger "eventos esportivos (...), em que a encomenda original e a produção estavam em conexão com um espetáculo ou sessão locais". ${ }^{78}$ No caso brasileiro, esta produção era pejorativamente chamada de cavação, prática que, apesar de tradicionalmente desprezada em favor dos

77 TOULMIN, Vanessa. Electric Edwardians: the story of the Mitchell \& Kenyon Collection. London: British Film Institute, 2006, p. 35.

${ }^{78}$ Ibidem. 
filmes de ficção, era "a realidade cinematográfica brasileira mais sólida"79 no período. Segundo Jean-Claude Bernardet, é justamente na produção não-ficcional, "ligada a uma elite mundana, financeira, política, militar, eclesiástica", ${ }^{80}$ que se assenta o cinema brasileiro e da qual dependem os produtores.

Uma carta escrita por Marc Ferrez e Filhos, em 20 de setembro de 1909, dia seguinte ao da corrida, indica como estavam ligados casa exibidora, membros da elite e produção do filme. Eles dizem a seu destinatário, J. Tous Roca, o seguinte:

\begin{abstract}
Aqui nada de anormal nem de interessante: houve hontem uma corrida de automoveis e podeis calcular que nada se pode tirar de interessante com tres operadores só, em caminhos cheios de pó e com automoveis em grande velocidade. Fizemos o trabalho a contracto com o Odeon que de seu lado fez contracto de publicidade com os agentes dos carros vencedores. Parece-nos que vamos exhibir mais titulos do que propriamente fita de vista. Nada absolutamente de interessante a não ser para os que assistiram e querem o seu retrato na archibancada. ${ }^{81}$
\end{abstract}

Algumas informações chamam a atenção. Em primeiro lugar, a de que três operadores cinematográficos participaram da filmagem. Talvez tenham sido eles Paulino Botelho e outros dois, das companhias "Vallé" e "Eclypse", 82 citadas anteriormente. É possível ver os tripés de outros cinegrafistas mais de uma vez no filme. Em segundo, o dado sobre a dificuldade em se filmar a corrida, tanto por conta da alta velocidade dos automóveis, como pelo pó que sua passagem fazia subir do chão, ligado ao que eles dizem sobre exibir mais "títulos" do que "fita de vista". Pode ser que, com a visibilidade obstruída pela poeira, os Ferrez estivessem cogitando preencher lacunas do filme com cartelas de texto. ${ }^{83}$ Outra parte importante da carta aponta para a estreita relação, da qual o filme é fruto, entre automobilistas, sala exibidora e companhia produtora. O cinema Odeon, que tinha sido inaugurado em 16 de agosto de 1909, cerca de um mês antes da corrida, parece ter estado no centro deste negócio que envolveu, de um lado, os competidores (membros da

\footnotetext{
${ }^{79}$ BERNARDET, Jean-Claude. Cinema brasileiro: propostas para uma história. São Paulo: Companhia das Letras, 2009, p. 43.

${ }^{80}$ Idem, p. 40.

${ }^{81}$ Referência do documento no Arquivo Nacional: FF-FMF 2.0.1.14. Agradecemos à pesquisadora Danielle Carvalho pelo envio da cópia desta carta.

${ }^{82}$ Por enquanto, encontramos anúncios do Cinematographo Paraiso do Rio, de propriedade de Silveira Pinto \& C., desde 22 de agosto de 1908 no Jornal do Brasil (RJ), que anunciam filmes "do grande fabricante Eclipse". Os anúncios começam a aparecer um mês depois que a Eclipse (empresa francesa que havia tomado conta da franquia parisiense da britânica Charles Urban Trading Company em novembro de 1906), por conta de um aumento de capital, passou a lançar filmes em kinemacolor de Charles Urban e George A. Smith. Cf. MANNONI, Laurent. Eclipse. In: ABEL, Richard (Ed.). Encyclopedia of early cinema. New York: Routledge, 2005, p. 199.

${ }^{83}$ Que, se foram mesmo produzidas, não sobreviveram até nós, pelo menos até onde pudemos pesquisar.
} 
elite interessados na publicidade de si e de seus carros) e, de outro, os produtores das imagens cinematográficas. Por fim, os Ferrez deixam claro que o filme interessa apenas a quem esteve nas arquibancadas e quis ver a si mesmo na sala de cinema.

Como atestam a presença do binóculo, a data de exibição da película, e os contratos firmados entre produtores, sala de cinema e agentes dos competidores, observar as figuras presentes no evento foi parte importante do espetáculo, assim como, posteriormente, ver-se na tela. Pois, segundo Tom Gunning, "é o clamor por reconhecimento que batiza esse cinema da localidade". ${ }^{84} \mathrm{E}$ sabemos que situações cujo foco estava em ver e ser visto já faziam parte da rotina da elite carioca, que vivia naqueles $\operatorname{anos}^{85}$ uma crescente "espetacularização social e cultural". ${ }^{86}$

Nos dias que antecederam a corrida, os comentários jornalísticos trataram, entre outros aspectos, justamente da elegância e modernidade do evento, que aparece, por exemplo, neste trecho retirado da coluna "O Binóculo", de Figueiredo Pimentel, cronista empenhado na construção de uma imagem cosmopolita para o Rio de Janeiro:

\begin{abstract}
Effectivamente vae ser uma festa chic, uma festa chic como poucas vezes se têm realisado no Brasil. Basta dizer que é uma corrida de amadores, e não de profissionaes. E esses amadores são cavalheiros distinctissimos dos mais conceituados e smarts da nossa alta sociedade. ${ }^{87}$
\end{abstract}

O caráter esportivo do evento deixa clara a diferença entre proprietários e funcionários do mundo automobilístico: é como amadores que os ricos poderão guiar automóveis, entendendo a atividade como um esporte, jamais como profissão. Como já apontou Nicolau Sevcenko:

\footnotetext{
Num país como o Brasil, aonde os automóveis chegaram como produtos importados de alto luxo, eles logo se tornaram instrumentos de ostentação, prestígio e poder. Inicialmente são adquiridos para fins desportivos, ou seja, correr pelas ruas da cidade, as únicas pavimentadas. Em seguida, atormentar os pedestres com a buzina ou aterrorizá-los com as rodas passa a ser, por si só, um esporte de elite. ${ }^{88}$
}

\footnotetext{
${ }^{84}$ GUNNING apud TOULMIN, Vanessa. Electric Edwardians: the story of the Mitchell \& Kenyon Collection. London: British Film Institute, 2006, p. 35, grifo nosso.

85 Alguns anos antes do circuito, a prefeitura de Pereira Passos (1902-1906) fora responsável pelo alargamento das ruas e afrancesamento das fachadas do Rio de Janeiro, nossa capital federal de então. Foi Passos que criou o marco que foi a Avenida Central, que era cada vez mais usada como palco da sociabilidade da elite carioca (Cf. SOUZA, José Inácio de Melo. Imagens do passado: São Paulo e Rio de Janeiro nos primórdios do cinema. São Paulo: Editora Senac, 2004, p. 105-118).

${ }^{86}$ SOUZA, José Inácio de Melo. Op. cit., p. 44.

${ }^{87}$ BINOCULO. Gazeta de Notícias. Rio de Janeiro, 04/09/1909, p. 4.

${ }^{88}$ SEVCENKO, Nicolau. A capital irradiante: técnica, ritmos e ritos do Rio. In: História da vida privada (v. 3) - República: da Belle Époque à Era do Rádio. São Paulo: Cia. das Letras, 1998, p. 560.
} 
O esporte macabro dos ricos, aqueles que até então atravessavam a cidade de modo não regulado em busca de uma espetacularização da velocidade, ganha contornos oficiais com a organização da corrida.

Quando mostra a elite que se exibia nas arquibancadas, o filme se assemelha às imagens já publicadas na imprensa. Aquelas pessoas foram alvo das lentes que registraram imagens posteriormente divulgadas em jornais, revistas e nas imagens em movimento; em vistas mais panorâmicas e em tomadas mais próximas, sendo possível identificar sua fisionomia (figuras 23, 24, 25 e 26).

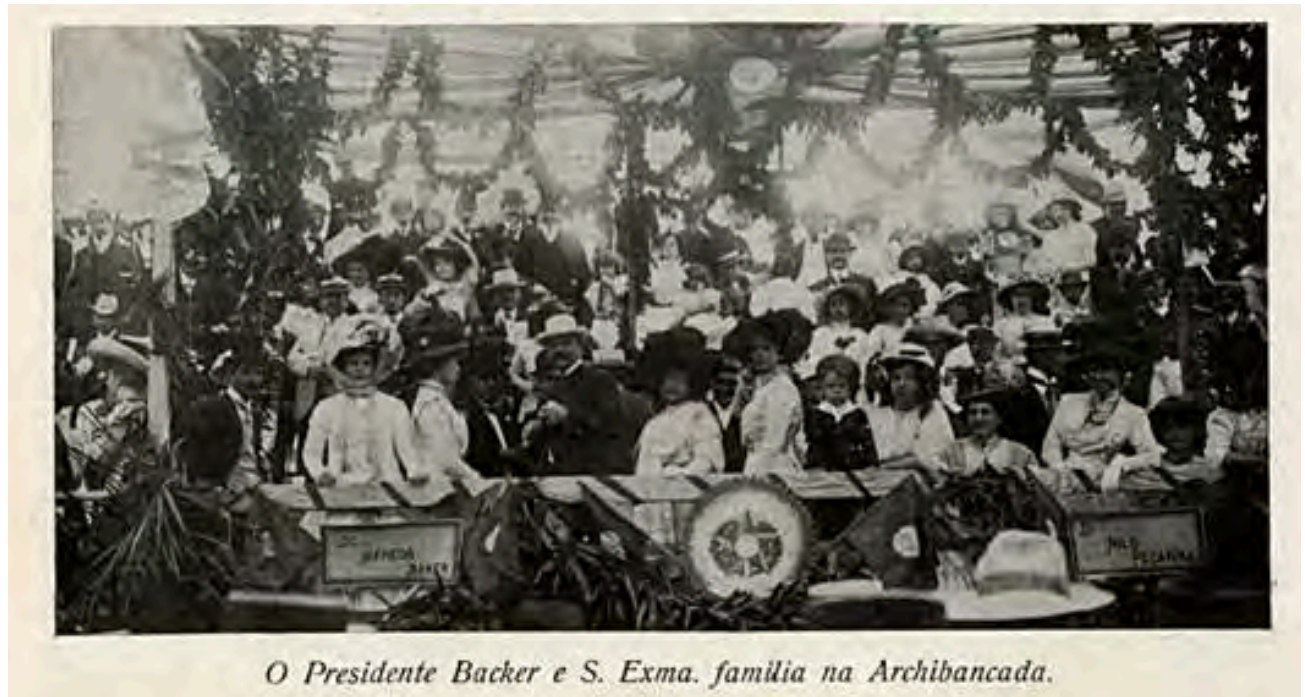

Figura 23 - Careta. Rio de Janeiro, 25/09/1909, p. 12, detalhe.

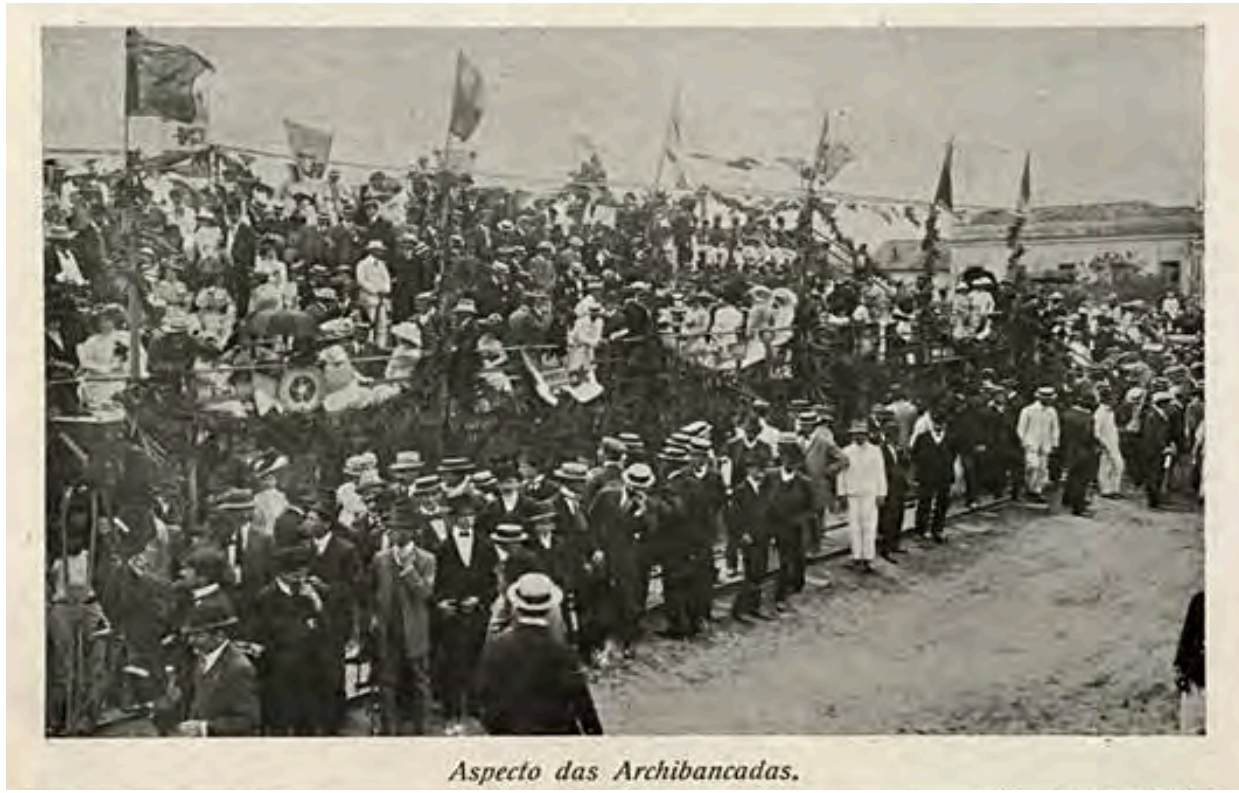

Figura 24 - Careta. Rio de Janeiro, 25/09/1909, p. 12, detalhe. 


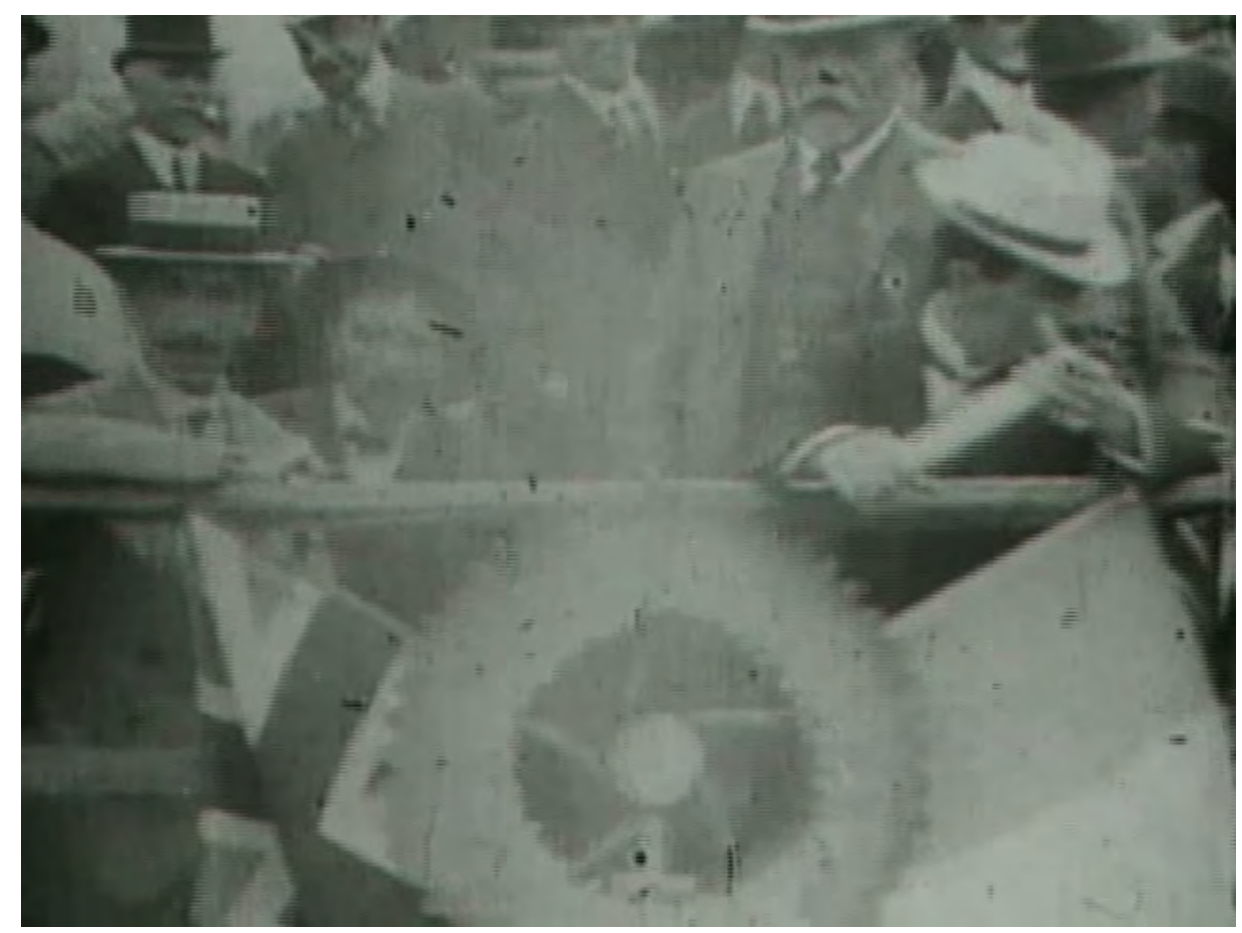

Figura 25 - Circuito de São Gonçalo (1909).

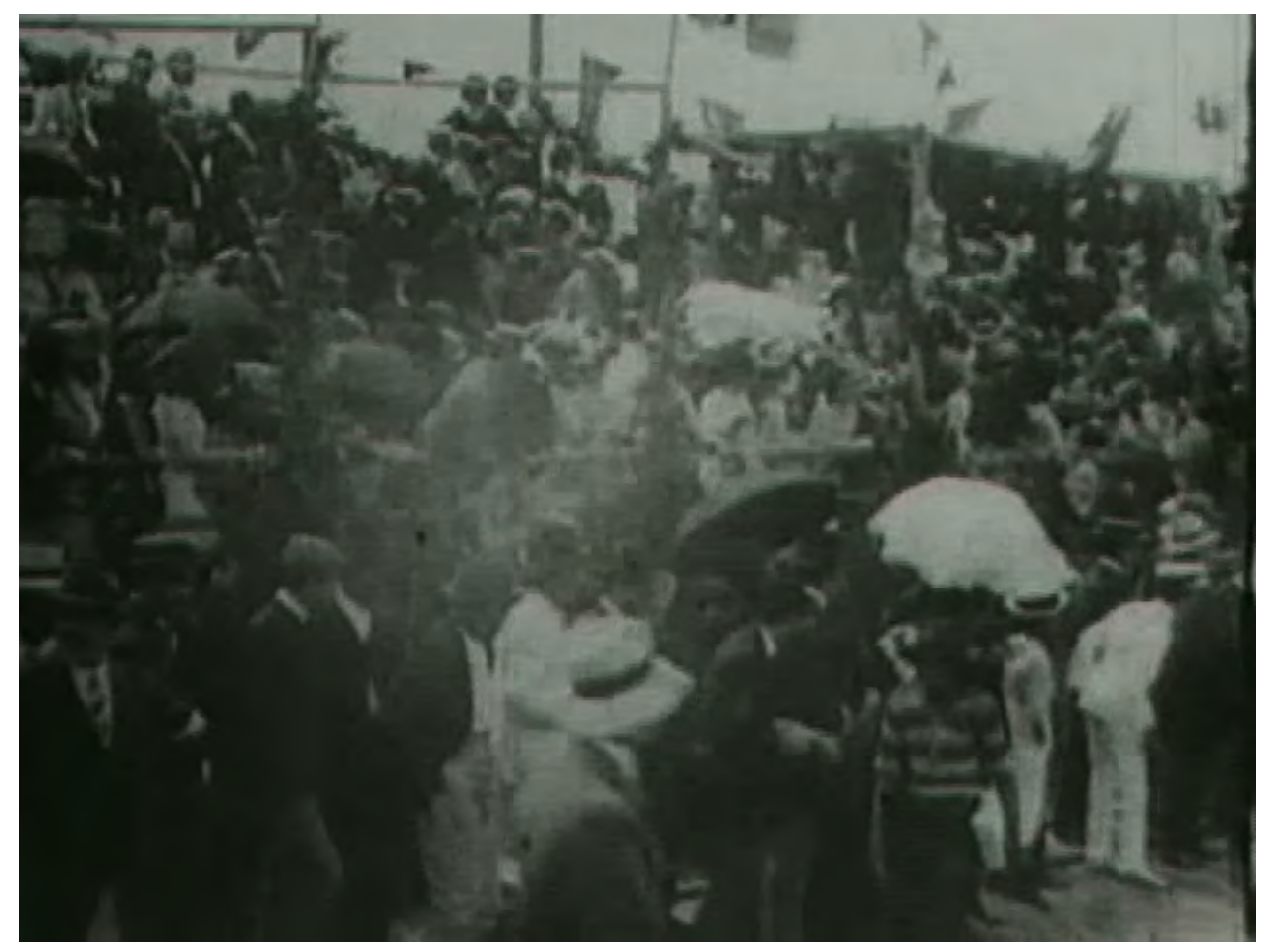

Figura 26 - Circuito de São Gonçalo (1909).

Esses planos panorâmicos nos dão a ver a multidão agitada que se concentra por ali, nas proximidades da linha de partida e chegada. De um lado da pista, uma plateia abarrotada, todos no nível do chão. A câmera passa rapidamente por eles, para deter-se 
no contingente agrupado do outro lado, sobre as enormes arquibancadas, ocupadas confortavelmente por muitos homens, mulheres e crianças - eles sim, facilmente discerníveis. Na primeira fileira, fartamente decorada com bandeirinhas e brasões do Automóvel Clube, eles apoiam seus braços no corrimão enquanto observam o entorno. As arquibancadas, que ficam acima da altura dos olhos daqueles que pisavam no chão de terra, são vistas em longos planos que mostram os membros da elite sobre a estrutura de madeira, de perto. Fica clara a escolha de enquadrar apenas os ricos, em detrimento da massa anônima que os rodeava.

É um procedimento análogo à tentativa de apagamento das figuras populares que aparece em outros filmes brasileiros do período, como mostrou Eduardo Morettin em sua análise de Barão do Rio Branco - A nação em luto - Os funeraes (1912), filmado por Alberto Botelho. Naquele filme, segundo o autor, a tensão entre os cidadãos curiosos e a busca pela afirmação simbólica do poder das elites leva o operador a enquadrar o Palácio do Itamaraty, em contra-plongée, afim de evitar a "interferência" dos transeuntes. ${ }^{89}$ Em Circuito de São Gonçalo, a própria arquibancada, repleta de membros das elites política, econômica e cultural, faz as vezes de monumento pomposo, que merece ser examinado minuciosamente pelo filme, enquadrado de modo a destacar apenas o que importava: aqueles espectadores, ricos o suficiente para pagar o ingresso que dava acesso não tanto a um ponto de vista privilegiado, mas a uma plataforma privilegiada de exibição.

Apesar de as fotografias publicadas na revista Careta não mostrarem a massa anônima (como faz o filme, mesmo que rapidamente), uma foto aponta para o aspecto rústico do local, ao mostrar as arquibancadas de um ângulo inusitado. Nesta imagem (figura 27), vemos a parte de trás da construção e é evidenciado seu caráter provisório.

\footnotetext{
${ }^{89}$ MORETTIN, Eduardo. O Rio de Janeiro no documentário brasileiro do período silencioso: imagens, circuitos e formulações críticas. In: KUSHNIR, Beatriz; VIEIRA, João Luiz. Rio: 450 anos de cinema. Rio de Janeiro: Em Tempo; FAPERJ, 2016, p. 24.
} 


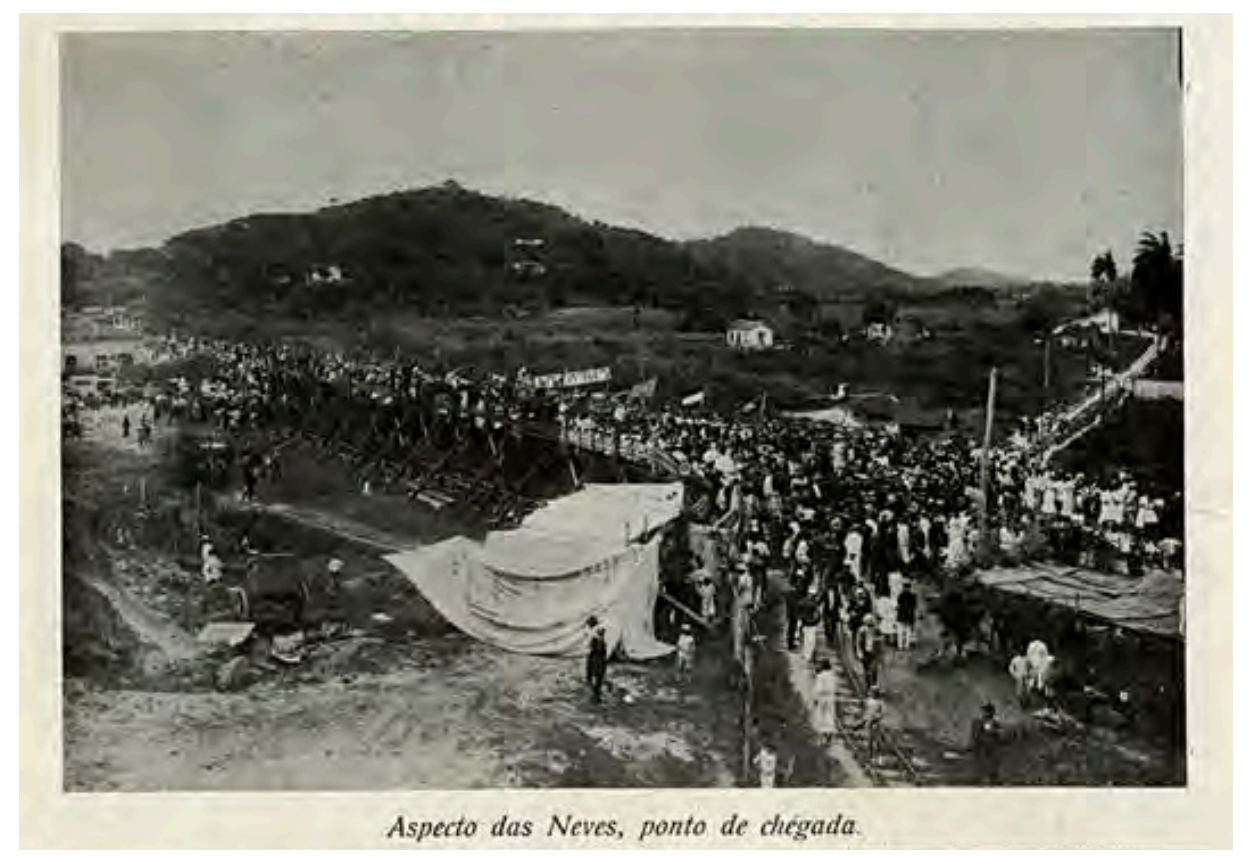

Figura 27 - Careta. Rio de Janeiro, 25/09/1909, p. 16, detalhe.

Mesmo que o carro tenha demorado muitos anos para se popularizar no Brasil, assistia-se naquela época a um grande crescimento no número de veículos desse tipo. A realização dessa corrida parece ter sido mais um meio, entre outros, que a elite carioca buscou para aproximar-se da modernização em curso nos países centrais, principalmente na França, onde os circuitos automobilísticos já tinham alguns anos de história. O que distingue o circuito de outros eventos em que o automóvel ganhava destaque, como os corsos e as batalhas das flores, ${ }^{90}$ é que, na corrida, a velocidade (que chegou à "vertigem"91 de 70 quilômetros por hora) e o perigo decorrente dela parecem ter constituído uma atração em si. Os corsos, além de buscarem associar os membros da chamada alta sociedade a um dos maiores símbolos modernos da época, estavam principalmente a serviço da exibição pública daquelas pessoas.

Então começa a segunda parte do filme. São sete planos, cada um mostra um automóvel passar pela pista, que, na maioria das vezes, forma uma diagonal no quadro. Primeiro vemos a largada do carro de número quatro, que sabemos ter sido o vencedor. Em uma das margens, gramado; na outra, casas geminadas, provavelmente de trabalhadores, que se posicionam nas janelas e portões para assistir à passagem das máquinas.

\footnotetext{
90 As batalhas das flores eram corsos especiais em que plantas ornamentais decoravam carruagens, bicicletas e automóveis.

${ }^{91}$ CORRIDA de automoveis. Gazeta de notícias. Rio de Janeiro, 20/10/1909, p. 1.
} 


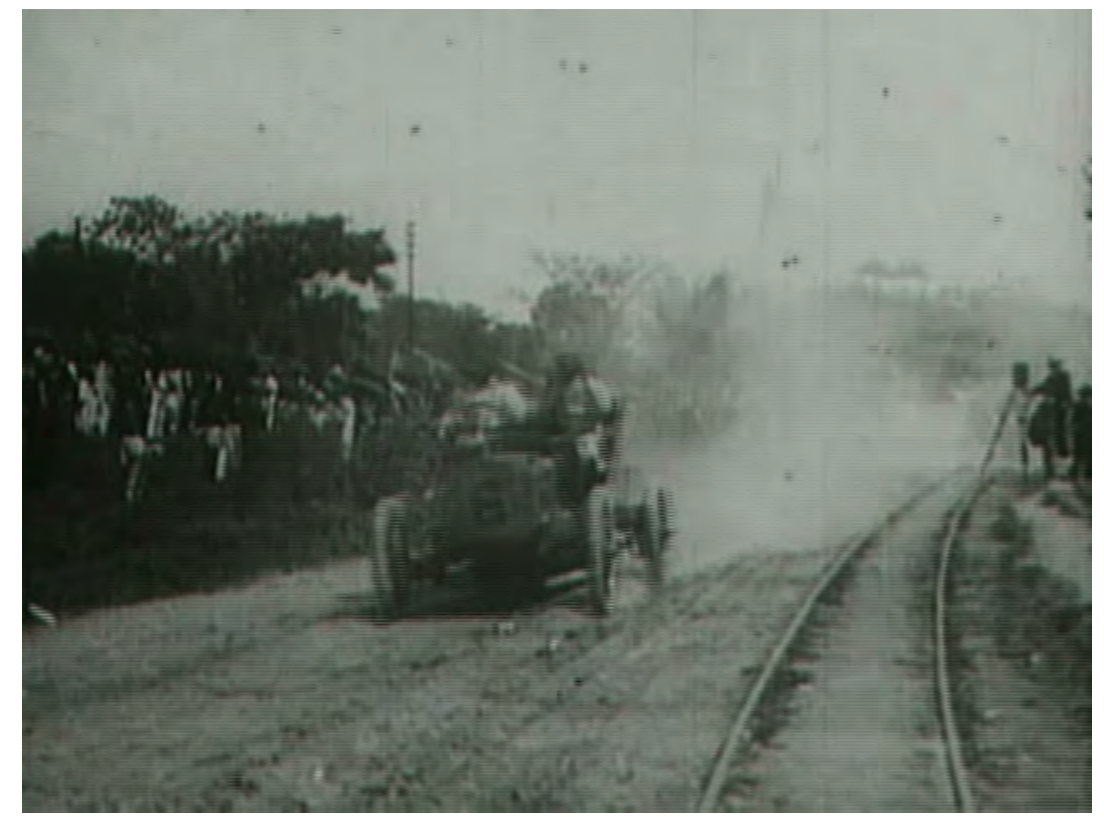

Figura 28 - Circuito de São Gonçalo (1909).

Podemos ver a partida de outros carros de diferentes pontos de vista. É nestes planos que outras câmeras de filmagem e seus operadores aparecem em quadro (figura 28, à direita). Muitos dos elementos em cena lembram uma das primeiras aparições de Carlitos, personagem de Charles Chaplin, em Corridas de automóveis para meninos (Kid auto races at Venice, Henry Lehrman, 1914). Assim como Circuito de São Gonçalo, o filme americano tem panorâmicas dos espectadores e planos da pista de corrida por onde passam as crianças dentro de seus pequenos carros de brinquedo, margeada pela multidão de espectadores e câmeras de filmagem. Longe de buscar uma relação direta entre os dois filmes, acreditamos que as semelhanças formais entre eles apontam para o enquadramento do filme brasileiro nas regras de composição dos filmes de corridas de automóveis, que vinham se estabelecendo, ao que tudo indica, principalmente na França e nos Estados Unidos, parodiadas anos depois por Carlitos.

A graça do curta reside nas atitudes do Vagabundo, que busca exibir-se a todo custo, interpondo-se entre a câmera e a corrida (figura 29). 


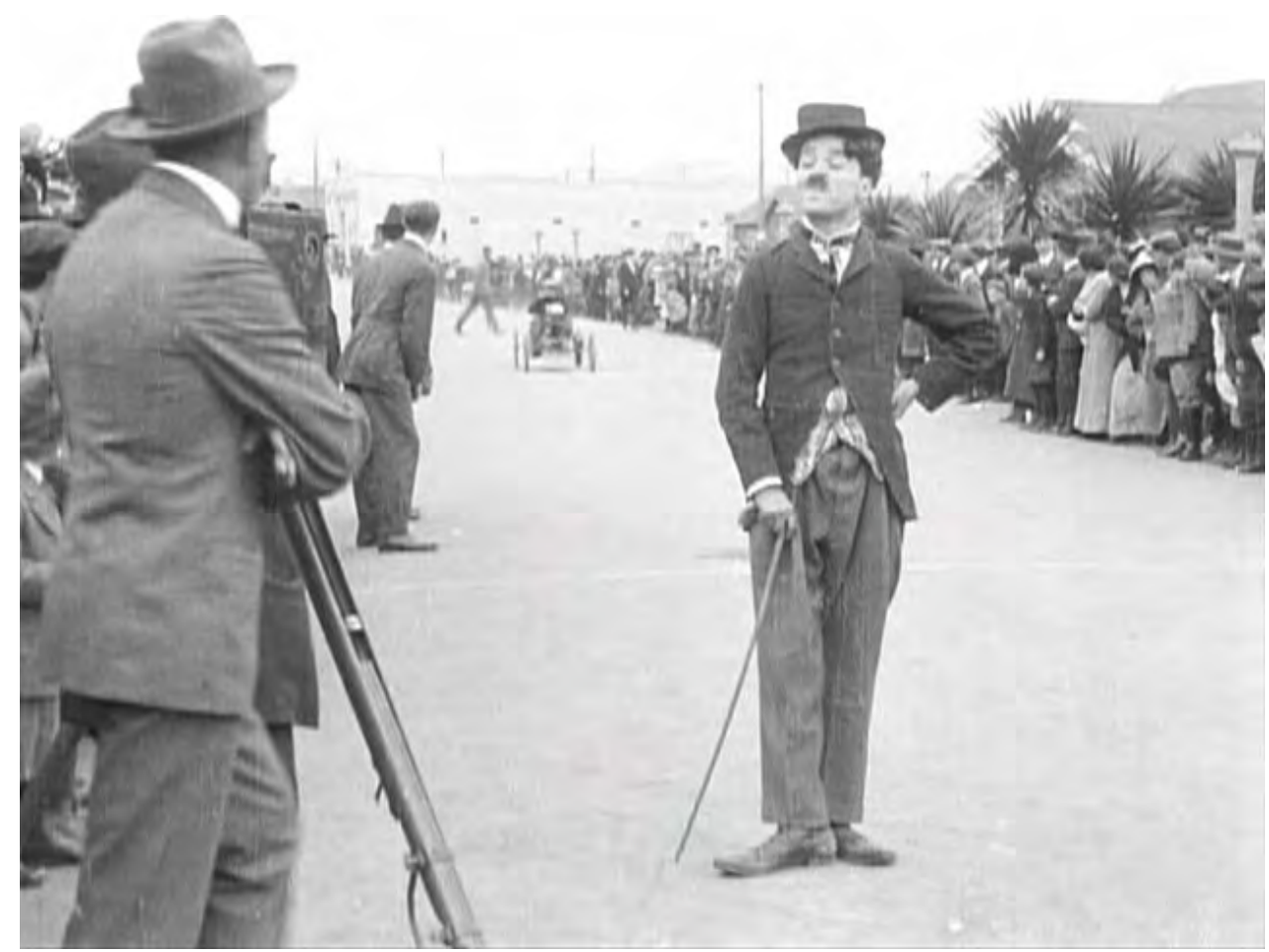

Figura 29 - Corridas de automóveis para meninos (Henry Lehrman, 1914).

Colocar-se entre as lentes e aquilo que elas focalizam, acenar ou sorrir para a câmera, atitudes comuns entre aqueles que passavam por filmagens em locais externos, quando exageradas por Chaplin, chamam a atenção justamente para o modo como filmes sobre eventos de rua tinham a capacidade de colocar em evidência aqueles que as câmeras focalizavam - no Brasil, os membros da elite. ${ }^{92}$

O que é importante notar é que, diferente dos populares que comumente sorriem, apontam e acenam na direção da câmera nos filmes da época, a elite presente no circuito não faz muito caso das lentes. Alguns poucos olham para a objetiva e até esboçam sorrisos discretos, mas ninguém demonstra qualquer excitação ligada ao fato de ser alvo das câmeras. Tudo isso parece muito natural e ordinário. Eduardo Morettin apontou comportamento semelhante no filme Barão do Rio Branco - A nação em luto - Os

\footnotetext{
${ }^{92}$ Como aponta Igor Andrade Pontes, o primeiro filme com Chaplin exibido no Rio de Janeiro foi, coincidentemente, outro que faz graça com o automobilismo: Izabel, condutora de automóveis (Mabel at the wheel, 1914, dirigido por Mabel Normand e Mack Sennett), o décimo primeiro filme com Chaplin lançado nos EUA. Ele foi lançado no Cinematógrafo Parisiense em 27 de julho de 1914. Pontes cita o Correio da Manhã (27/07/1914, p. 12): "Raramente se encontrará uma comédia com tanto chiste e tanta verve. Verdadeira fábrica de gargalhadas, esta comédia tem mais cenas interessantes que merecem que se lhes chame a atenção dos espectadores deste cinema: - uma corrida de automóveis, como comumente se realizam nos Estados Unidos. É um espetáculo interessante, com a concorrência enorme do povo, com derrapagens tremendas, com desastres. Tudo aproveitado na fita, vem lhe dar sabor todo especial.". Cf. PONTES, Igor Andrade. Os caminhos de Carlitos: a exibição dos filmes de Charles Chaplin no Rio de Janeiro, suas histórias e seus personagens (1914-1922). Dissertação (Mestrado em Comunicação Social). Universidade Federal Fluminense, Instituto de Arte e Comunicação Social, 2016, p. 19-21.
} 
funeraes (1912): “se há curiosidade por parte da população com relação à câmera, as elites a ignoram. (...) Ninguém dirige seu olhar para a câmera". ${ }^{93}$ Esse fenômeno parece ecoar a recepção "neutra" que os primeiros filmes parecem ter tido no Brasil, como comenta José Inácio de Melo Souza:

\begin{abstract}
O ânimo nacional quanto ao "nada nos é estrangeiro" pode significar que a elite europeizada que assistia às primeiras projeções tinha um ar blasé de quem tudo sabe, tudo conhece, nada lhe sendo estranho/estrangeiro. ${ }^{94}$
\end{abstract}

Parece ocorrer coisa semelhante nesses filmes em que a elite era focalizada: a própria postura corporal contida era sinal de distinção. Conforme diz Morettin, isso "traduz um comportamento de classe diferente em relação ao novo aparato". 95

\title{
Perseguição automobilística
}

Outro aspecto dessa seção de Circuito de São Gonçalo é a repetição da forma dos planos. Quase todas as vezes que um carro percorre a porção da pista enquadrada pela câmera e desaparece pela lateral do quadro, outro reaparece, no plano seguinte, pela lateral oposta da tela, quase que refazendo a trajetória do anterior. Esse tipo de repetição marcou a estrutura de um dos gêneros fílmicos mais populares dos Estados Unidos entre 1903 e 1906, o filme de perseguição. ${ }^{96}$ Esses curtas, que consistiam geralmente em um grupo de pessoas que perseguia um indivíduo por motivos diversos (exemplos clássicos são mulheres atrás de um aristocrata solteiro ou policiais atrás de um ladrão), são "todos marcados por uma fascinação pela biomecânica da corrida". ${ }^{97}$ Em muitos desses filmes, inclusive, veículos de diferentes tipos eram usados nas perseguições, sempre causando acidentes que envolviam outros passantes e acabavam por aumentar o número de perseguidores furiosos a cada plano. Como explica Jonathan Auerbach, "a perseguição cria um espaço sintético imaginário maior que suas partes individuais, o que permite que o espectador siga os corpos que correm pelo quadro de uma cena a outra". ${ }^{98}$ Mas, ao

\footnotetext{
${ }^{93}$ MORETTIN, Eduardo. O Rio de Janeiro no documentário brasileiro do período silencioso: imagens, circuitos e formulações críticas. In: KUSHNIR, Beatriz; VIEIRA, João Luiz. Rio: 450 anos de cinema. Rio de Janeiro: Em Tempo; FAPERJ, 2016, p. 25-26.

94 SOUZA, José Inácio de Melo. Imagens do passado: São Paulo e Rio de Janeiro nos primórdios do cinema. São Paulo: Editora Senac, 2004, p. 242.

${ }_{95}$ MORETTIN, Eduardo. Op. cit., p. 26, grifo nosso.

96 AUERBACH, Jonathan. Chase films. In: ABEL, Richard (Ed.). Encyclopedia of Early Cinema. New York: Routledge, 2005, p. 110.

${ }^{97}$ Ibidem.

${ }^{98}$ Ibidem.
} 
mesmo tempo em que constrói este espaço sintético, maior que suas partes, o filme de perseguição também preserva a autonomia do plano: cada cena começava normalmente com o espaço vazio, para que entrassem em cena perseguido(s) e perseguidores, que saíam de quadro de modo que o plano ainda se estendia para mostrar novamente o vazio (e o caos deixado por sua passagem).

Em nosso filme, também se constrói um espaço maior (o circuito de 72 quilômetros) por meio da junção de unidades menores (os planos que mostram pequenas porções da pista). E, apesar de não ser exatamente uma perseguição, mas uma competição automobilística, o tipo de plano escolhido e sua montagem na construção do filme sugerem que, para todo carro que passa, há outro que o segue. Em cada um desses planos, uma cortina de poeira e fumaça, rastro que apaga quase todos os outros elementos em cena, também segue, de perto, os automóveis (figura 30).

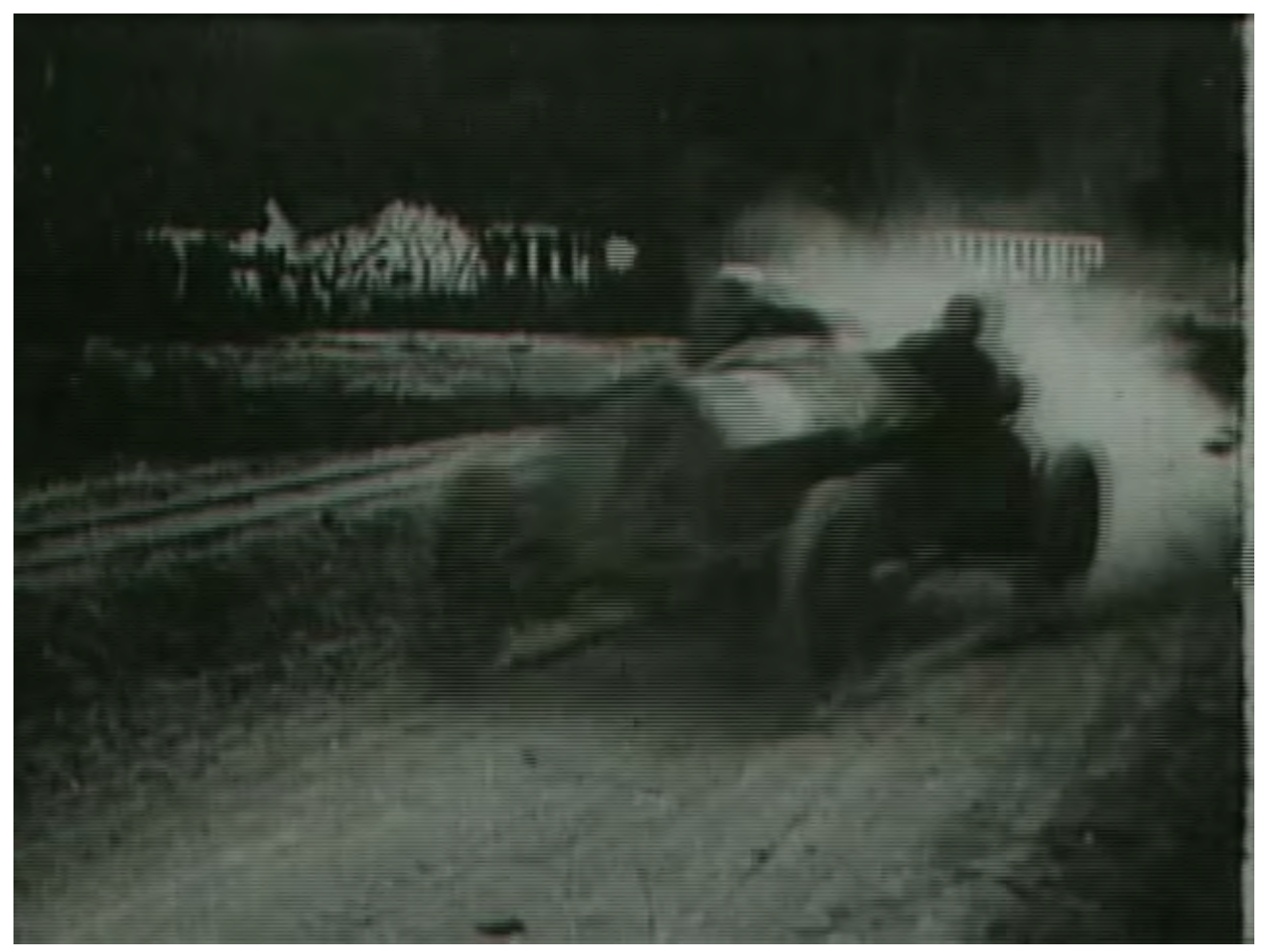

Figura 30 - Circuito de São Gonçalo (1909).

Além da atração presente no próprio movimento ao longo do quadro, nos filmes de perseguição, um dos interesses estava em como perseguidos e perseguidores superavam diferentes obstáculos, com efeito cômico. Aqui, não há dúvidas de que os produtores do filme buscaram enfatizar o aspecto perigoso da corrida ao apontar a câmera para curvas 
e, principalmente, uma ponte que aparece sendo atravessada por três carros diferentes, em três planos seguidos.

A ênfase nas dificuldades do percurso já aparecia, naquela época, nas imagens ligadas à viagem e aos meios de transporte modernos, como os filmes de viagem fantasma ${ }^{99}$ e os cartões postais, ${ }^{100}$ nos quais eram comuns as vistas de curvas, pontes, viadutos, passarelas, túneis. A apresentação desses obstáculos parece colocar o observador em contato com a excitação sensorial do tráfego moderno. Na França, foram editados inúmeros postais relacionados a corridas de automóveis, muitas vezes colecionáveis, que davam acesso visual a diversos pontos das pistas das corridas, aos retratos dos pilotos etc. Com frequência, a descrição desses postais enfatizava o perigo das corridas, como neste exemplo, sobre o Circuito de la Sarthe (figura 31).

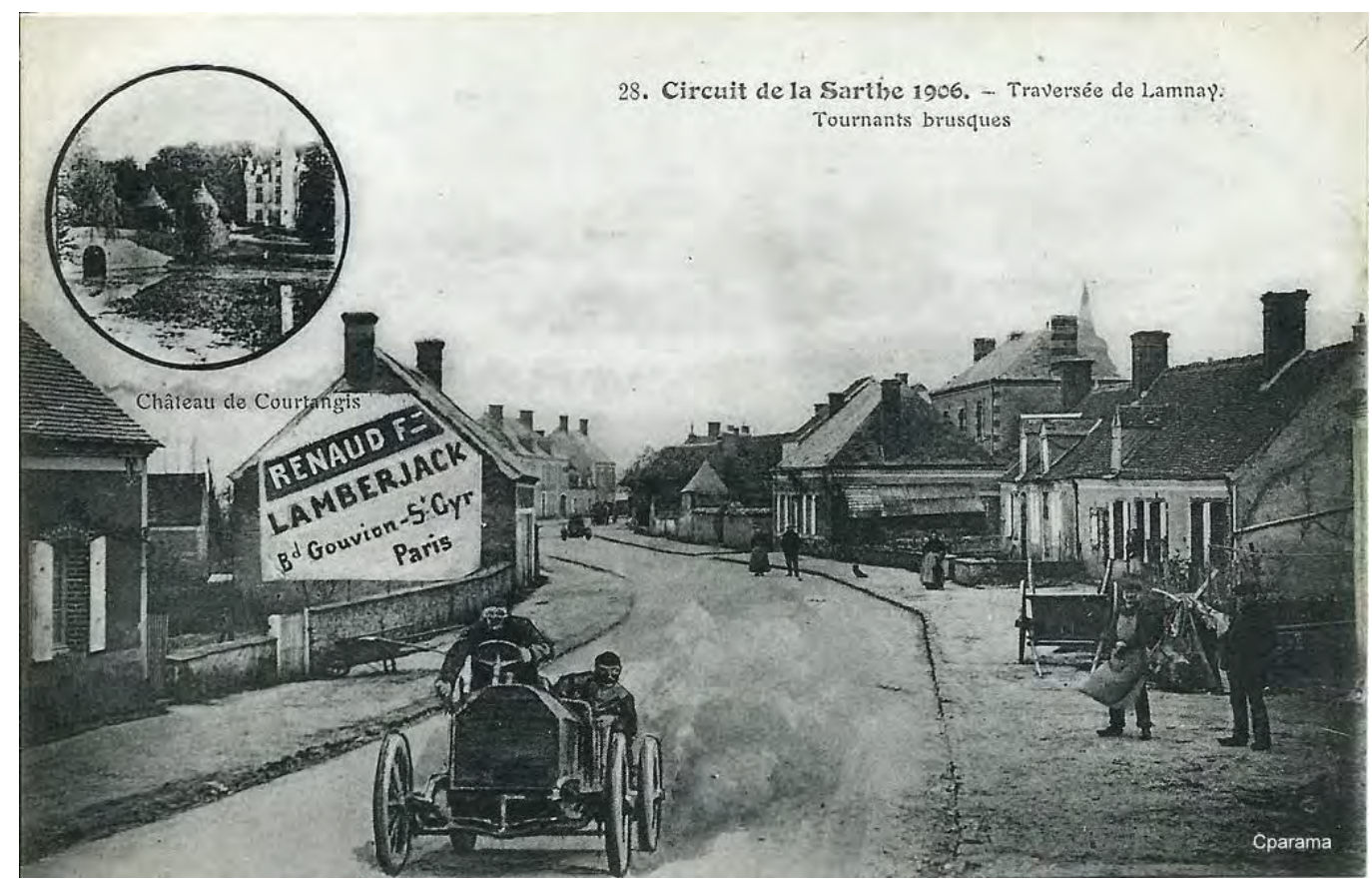

Figura 31 - Cartão postal francês, composto por meio de colagem de fotografia e ilustração, onde se lê: "Circuito de la Sarthe 1906. Travessia de Lammay. Curvas fechadas."101

\footnotetext{
${ }^{99} \mathrm{O}$ gênero é discutido no segundo capítulo da dissertação.

${ }^{100}$ Vários exemplos podem ser consultados na seção de automóveis do Forum et galerie de cartes postales anciennes de France. Disponível em: < http://www.cparama.com/forum/automobiles-et-voituresf158.html >. Acesso em: 08/06/2017.

101 Forum et galerie de cartes postales anciennes de France. Disponível em: < http://www.cparama.com/forum/cartes2014a/1412752036-Circuit-de-la-Sarthe-1906-Bouveret-28-.jpg >. Acesso em: 11/04/2018.
} 
As notícias dessas competições chegavam aos poucos na imprensa brasileira, que criavam colunas sobre automobilismo em suas páginas. ${ }^{102} \mathrm{E}$, como estava se tornando comum, também foi feito um filme sobre a corrida francesa - e ele foi exibido no Brasil. O circuito de la Sarthe ou, como também foi chamado, Grandes carreiras de automóveis (Circuit de la Sarthe, Pathé Frères, 1906), foi visto no Teatro Sant'Ana, em São Paulo, em 05/11/1906, e no Teatro Lírico, no Rio de Janeiro, em 27/09/1907, pelo menos. A duração parece ter sido de cerca de meia hora e o filme parece ter sido colorido. ${ }^{103}$ Uma versão em preto e branco, de cerca de 7 minutos, está disponível no sítio online dos Arquivos Gaumont Pathé. ${ }^{104}$ Resumidamente, o filme mostra a largada dos automóveis em frente às arquibancadas, vários carros passando uma mesma curva, alguns competidores nas áreas de paragem, troca de pneus e outros reparos, fotógrafos em exercício, carros acidentados na margem da pista, e, por fim, o público aplaudindo a chegada dos autos. Uma imagem que destoa é a que mostra um grupo de homens, provavelmente mecânicos, que almoçam alegres em uma mesa improvisada, bebendo vinho.

Além desse, outros filmes sobre corridas de automóveis foram exibidos no Rio de Janeiro antes da realização de Circuito de São Gonçalo: O circuito de Itapecerica (Antônio Leal, 1908), sobre a corrida considerada a primeira da América Latina, realizada em São Paulo; Circuito de Diepe ou Uma corrida de automóveis em Dieppe (Circuit de Dieppe, Pathé Frères, 1907) "grandiosa corrida de automóveis"; ${ }^{105}$ O Circuito de Dieppe 1908 ou Nos arredores de Dieppe (Circuit de Dieppe, Pathé Frères, 1908), "grande corrida internacional", ${ }^{106}$ a segunda realizada em Dieppe, na França.

Apesar de não termos notícia da vinda, para o Brasil, do cartaz de divulgação de Circuito de Dieppe, vale mencionar que o pôster mostra dois automóveis, um deles

\footnotetext{
102 "A Gazeta de Notícias, jornal moderno e um dos melhores do Brasil, no mês de abril [de 1906] inaugurava em suas páginas uma secção de automobilismo." ARAÚJO, Vicente de Paula. A Bela Época do Cinema Brasileiro. São Paulo: Editora Perspectiva, 1976, p. 184.

${ }^{103}$ Segundo a base de dados Cine Silencioso: Filmes estrangeiros exibidos no Brasil 1896-1916. Disponível em: < http://mnemocine.com.br/JCB/visualizar.php?id=451 >. Acesso em: 22/04/2018.

$104 \mathrm{O} \quad$ filme $\quad$ pode $\quad$ ser $\quad$ visto $\quad$ em: http://www.gaumontpathearchives.com/index.php?urlaction=doc \&tab=showExtraits\&id_doc=150037\&ra ng=2 >. Acesso em: 24/04/2018.

${ }^{105}$ Exibido no Teatro São José (30/12/1907) e no Pavilhão Internacional (04/01/1908) e também em São Paulo, no Bijou (25/11/1907). Cf. Cine Silencioso: Filmes estrangeiros exibidos no Brasil 1896-1916. Disponível em: < http://mnemocine.com.br/JCB/visualizar.php?id=956 >. Acesso em: 22/04/2018.

${ }^{106}$ CINEMATOGRAPHOS. A imprensa. Rio de Janeiro, 21/08/1908, p. 6. Exibido no Teatro São José (1908) e no Cinematógrafo Pathé (21/08/1908). Cf. Cine Silencioso: Filmes estrangeiros exibidos no Brasil 1896-1916. Disponível em: < http://mnemocine.com.br/JCB/visualizar.php?id=16073 >. Acesso em: $22 / 04 / 2018$
} 
arremessando o motorista para fora enquanto atropela uma pessoa (figura 32). A escolha dessa cena para compor o cartaz e, com ele, atrair o público, sugere que tipo de atração buscava-se vender.

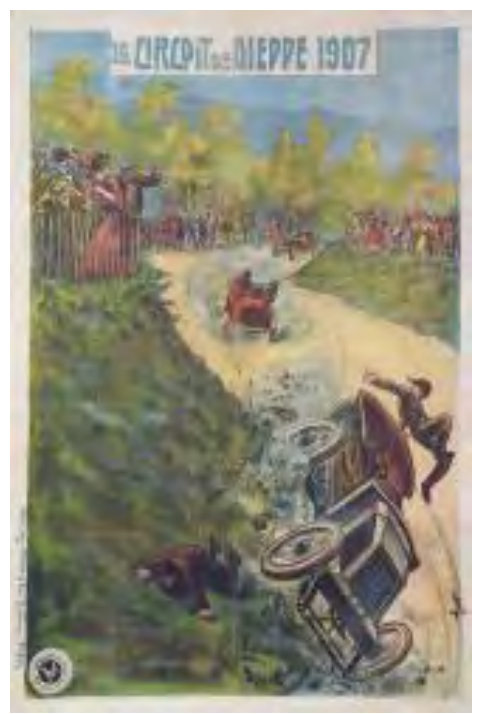

Figura 32 - Cartaz de divulgação de Circuito de Dieppe (Pathé Frères, 1907). ${ }^{107}$

O público, amontoado atrás de cercas de madeira que margeiam a estrada, parece acumular-se na curva. As dobras da pista, ao mesmo tempo em que são obstáculos perigosos para os carros, são pontos de vista privilegiados para os espectadores. $\mathrm{O}$ filme foi preservado e também está disponível no sítio online dos arquivos Gaumont Pathé, com cerca de onze minutos e meio de duração.

O filme começa com o abastecimento dos automóveis, mostra a plateia em arquibancadas e os pilotos em planos frontais posados. Vemos também a largada de vários competidores e a passagem dos autos por diferentes pontos do percurso (como por baixo de viadutos e curvas). Assim como nas corridas de la Sarthe e São Gonçalo, a paisagem é rural, com poucas construções. A principal diferença com relação a este aspecto são as barreiras de proteção, que aparecem entre a pista e as casas, sempre que o percurso encontra áreas mais movimentadas. Uma sequência, que dura cerca de quatro minutos, merece nossa atenção. Por uma curva em "S", vemos passar muitos carros, que vêm em disparada na direção do espectador, saindo pela esquerda do quadro. São muitas derrapagens, poeira e fumaça. Não são raras as vezes em que vemos mais de um auto em

107 Circuit de Dieppe 1907 - anonyme. Fondation Jérôme Seydoux Pathé. Disponível em: < http://filmographie.fondation-jeromeseydoux-pathe.com/768-circuit-de-dieppe-1907 >. Acesso em: 08/06/2017. 
quadro, sem cortes. Fica evidente o perigo daquele ponto do percurso e a expectativa construída pela cena é enorme. Um carro chega a girar $360^{\circ}$ em torno de seu eixo, até que, finalmente, outro avança sobre a lateral da pista, por pouco não alcançando a cerca e os espectadores atrás dela, e capota. É aquela mesma cena representada pelo pôster. O competidor que vinha logo atrás dele também perde o controle e some pelo lado oposto. Os pilotos acidentados saltam rapidamente enquanto a máquina expele fumaça (figura $33)$.

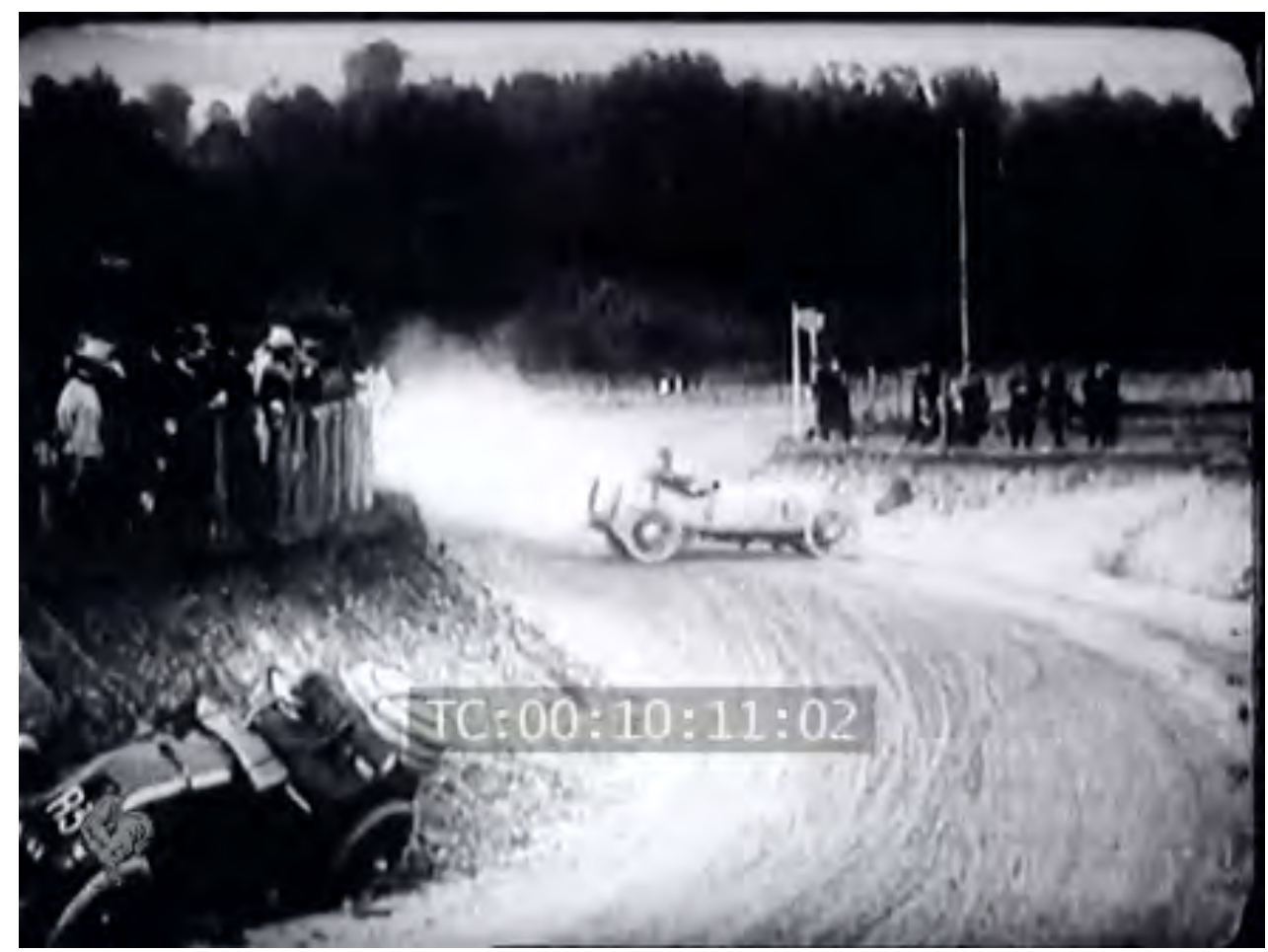

Figura 33 - Circuito de Dieppe (Pathé Frères, 1907): ${ }^{108}$ enquanto o carro capotado é removido, outro derrapa.

Depois disso, vemos vários outros carros passando pelo mesmo ponto, agora ainda mais tenso por conta do veículo que permanece na margem da pista. Para nós, o carro capotado está em primeiro plano, mas, para os competidores, era somente depois de uma curva que podiam vê-lo. Um homem, ao fundo, gesticula, pedindo diminuição da velocidade. Não é fácil tirar a máquina quebrada dali e, enquanto a remoção é realizada, com a ajuda de grossas cordas, nós, já sem fôlego, continuamos a acompanhar a passagem de tantos outros competidores pelo local do acidente. Depois disso, antes de o filme terminar,

\footnotetext{
108 Gaumont Pathé Archives. Disponível em: http://www.gaumontpathearchives.com/index.php?urlaction=doc \&tab=showExtraits\&id_doc=84704\&ran $\mathrm{g}=1>$. Acesso em: 24/04/2018.
} 
aparece o vencedor ao lado de seu carro, rodeado e outros homens, e a taça que ele ganhou.

Segundo Leslie Anne Lewis, no catálogo da $32^{\mathrm{a}}$ edição da Giornate del Cinema Muto, de 2013, onde o filme da Pathé foi recentemente exibido, os operadores se posicionaram nas curvas mais fechadas da pista, que tinha formato triangular, para "captar as cenas mais dramáticas possíveis". ${ }^{109} \mathrm{Na}$ corrida de Dieppe, inclusive, a morte de um piloto no treino aumentou a expectativa dos competidores e espectadores com relação ao perigo representado por ela. ${ }^{110} \mathrm{Na}$ sequência comentada por nós, a insistência em filmar a curva em "S" deixa evidente o desejo por captar imagens excitantes. A curva fechada já sugere o acidente em sua própria forma: é preciso ser muito habilidoso para superar um obstáculo como esse, em alta velocidade. Ainda segundo Lewis, esses filmes normalmente seguiam uma estrutura, que consistia em três partes: a preparação dos competidores, a corrida em si e a cerimônia de premiação.

Dessas três, nosso filme brasileiro apresenta as duas primeiras, o que pode ser mais um indício da incompletude das imagens que sobreviveram. Assim como os cartões postais, os filmes de corridas automobilísticas davam acesso visual aos interessados em geral, atingindo um público mais amplo por serem atrações mais baratas, mas também ao público pagante presente nos eventos, que normalmente só via a largada e a chegada, onde eram montadas as arquibancadas.

Apesar do interesse pelo contingente, intimamente ligado ao surgimento do cinema no final do século XIX, quase nunca as câmeras conseguiam captar eventos inesperados. Segundo Paul Virilio, filósofo francês que dedicou grande parte de sua obra à questão do aceleramento da vida moderna, "o acidente é inseparável da velocidade com a qual ele surge inesperadamente" ${ }^{111}$. Por isso, era comum, durante as duas primeiras décadas do cinema, que os produtores contornassem a dificuldade de captar os acontecimentos efêmeros com reencenações ou outros recursos. É o caso de Uma colisão ferroviária (A railway collision, R. W. Paul, 1900), para citar apenas um exemplo no campo dos filmes sobre os perigos dos transportes modernos. O curta faz uso de uma maquete para a representação de duas locomotivas que batem de frente. A maior parte de sua duração é dedicada à construção da expectativa para o acidente e, uma vez que acontece, o filme termina abruptamente. Em vez de acreditar que os espectadores da

\footnotetext{
${ }^{109}$ LE Giornate del Cinema Muto, Pordenone, 5-12 ottobre 2013: Catalogo, p. 169.

${ }^{110}$ Idem, p. 169.

${ }^{111}$ VIRILIO, Paul. The original accident. Cambridge, Malden: Polity Press, 2007, p. 12.
} 
época não fossem capazes de distinguir uma maquete de uma paisagem real, cabe questionar se parte do interesse do filme não pode ter residido justamente na capacidade que o cinema tem de fazer uma maquete parecer a realidade, dando ao público a rara possibilidade de ver um acidente, mesmo que cenográfico, no momento em que ocorre. $\mathrm{Na}$ corrida, todo um cenário é construído para o acidente. Desde a preocupação das autoridades até a presença das câmeras, passando pela própria forma do percurso, tudo parece convergir para a espetacularização do desastre.

\section{A morte do motor}

Em Circuito de São Gonçalo, apesar dos acidentes terem sido esperados e até talvez ansiados, eles aconteceram fora do campo de visão das câmeras. Ou, se foram produzidas imagens em movimento desses instantes, não sobreviveram até nós. O que o filme nos mostra, então, são dois tipos diferentes de imagens ligadas aos acidentes: o aspecto dos automóveis depois das batidas e um momento angustiante, no qual um dos carros quase atropela alguns animais, o que nos leva a terceira e última parte do curta.

Os carros, antes potentes, aparentemente indestrutíveis, aparecem agora desfigurados, amassados, despedaçados. A fumaça reaparece, não mais como índice da velocidade ou sinal da precariedade da pista, mas como uma espécie de último suspiro do motor que, aos poucos, desiste de funcionar. Dentre os olhares curiosos de homens que rodeiam as máquinas destruídas, a câmera também observa, examinando-as por diferentes pontos de vista. Um homem acena e sorri para nós: é a única figura do filme a interagir assim com a câmera (figura 34). O Circuito de São Gonçalo foi uma situação em que a elite pôde não só exibir a si mesma e a seus carros, mas, talvez principalmente, colocálos em risco. Colocar em risco objetos de valor em nome da diversão pode funcionar como um poderoso sinal de distinção social. 


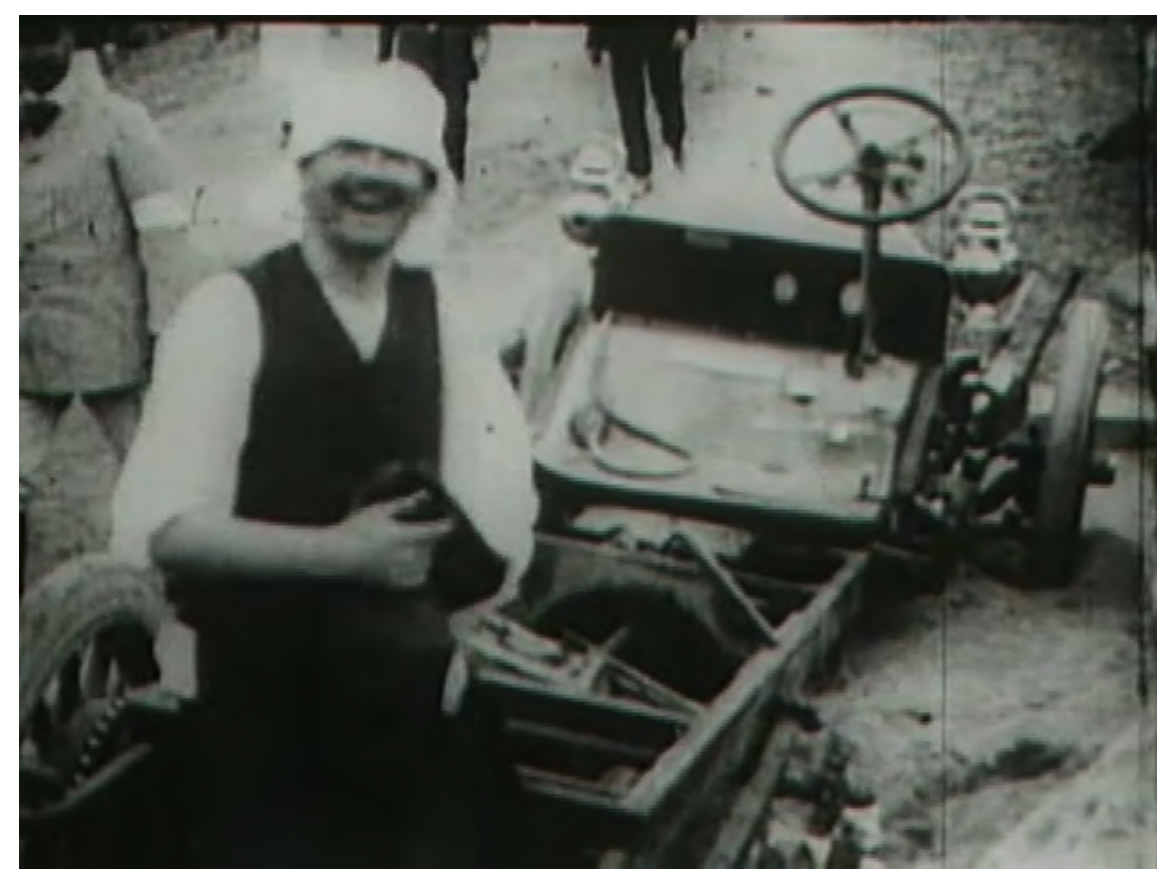

Figura 34 - Circuito de São Gonçalo (1909).

Imagens de carros destruídos depois de acidentes também eram comuns nos cartões postais franceses de corridas. Neste exemplo (figura 35), do circuito Paris-Madri, de 1903, temos uma imagem semelhante ao frame do filme reproduzido acima.

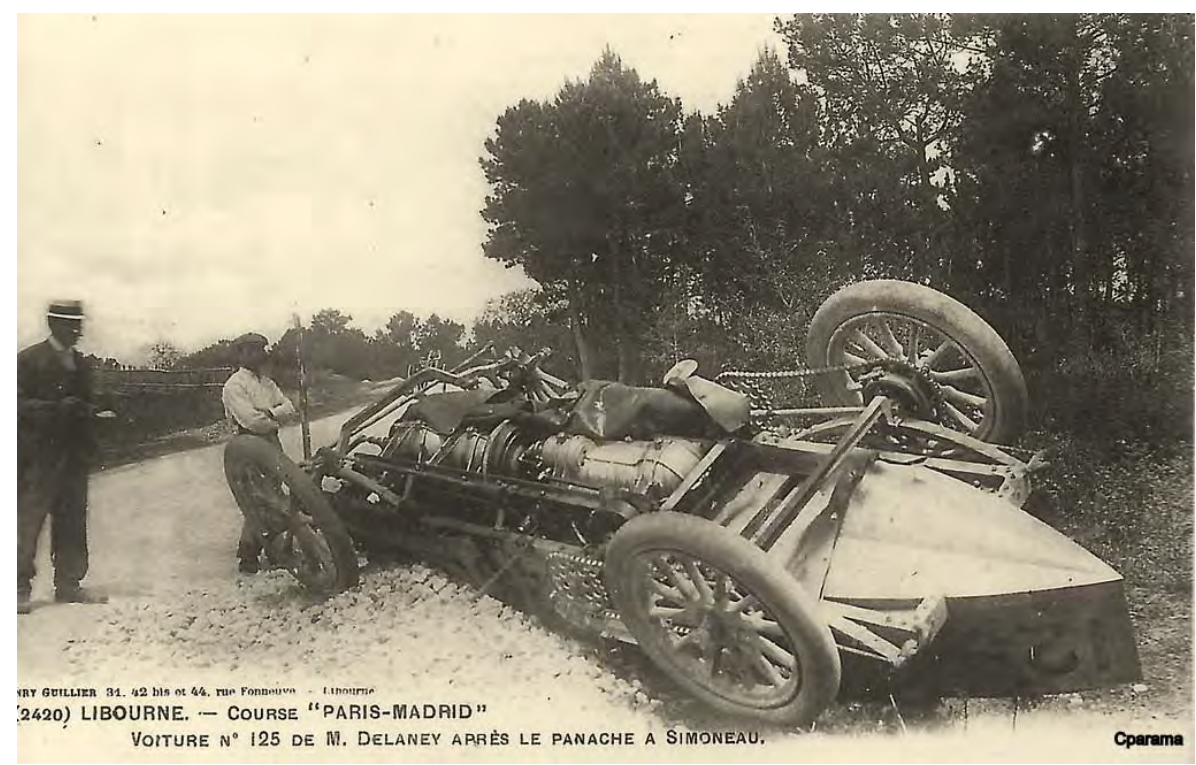

Figura 35 - Cartão postal francês do circuito Paris-Madri, 1903. ${ }^{112}$

112 Forum et galerie de cartes postales anciennes de France. Disponível em: <http://www.cparama.com/forum/cartes2014a/1410340362-Paris-Madrid-22-.jpg>. Consultado em: $10 / 06 / 2017$. 
Vejamos mais de perto outro exemplo, em que o perigo iminente ligado ao automóvel ganha destaque: Explosão de um veículo motorizado (Explosion of a motor car, Hepworth Manufacturing, 1900), um filme curto e impactante. Em uma rua residencial, algumas pessoas atravessam de uma calçada à outra enquanto um automóvel vem em nossa direção. O motorista conduz quatro passageiras animadas. De repente, o veículo sofre uma enorme explosão e se transforma em alguns poucos destroços: uma roda jogada, o volante caído. Um policial se aproxima e olha para o céu, assustado. Das mulheres, que há segundos acenavam para nós com lencinhos brancos, e do homem que as levava por um passeio festivo, caem do céu pernas amputadas, troncos sem cabeça e braços decepados. Enquanto desvia do que sobrou daqueles corpos, o policial recolhe calmamente cada uma das partes, fazendo anotações em seu bloquinho de papel, como se registrasse multas de trânsito. E é com corpos despedaçados, empilhados no meio da rua, que termina o curta, depois de menos de dois minutos de duração. ${ }^{113}$

A explosão, ponto de virada do filme, foi criada por meio de uma trucagem, a chamada parada para substituição. Para alcançar o efeito de transformação repentina, o carro foi retirado de cena e, em seu lugar, foram colocados os destroços, filmados com o mesmo enquadramento. Se, logo antes do corte, a fumaça cobria o veículo, ela reaparece com os destroços, ligando os planos e dissipando-se logo. Até aí, vimos a representação cinematográfica de um carro que explode subitamente. $\mathrm{O}$ que mais surpreende e gera efeito cômico é a reação neutra do policial à chuva macabra de membros cenográficos, atração principal do filme. Mas, apesar de parecer absurdo que pedaços de corpos caiam do céu, o atropelamento por automóvel já estava longe de ser um acontecimento raro e invadia cada vez mais o imaginário do cidadão de uma metrópole como a Londres daquele momento, quando a recente indústria do automóvel não parava de crescer ${ }^{114}$. Do mesmo modo, apesar de a neutralidade do policial ser exagerada, ela não é totalmente inverossímil. A função do oficial é apenas a de "reorganizar" o que o carro

\footnotetext{
${ }^{113}$ Flavia Cesarino Costa começa seu livro sobre o primeiro cinema com uma comovente descrição desse filme. Para a autora, ele apresenta uma fusão de "brevidade, anarquia, senso de humor [e] trucagens", características típicas dos primeiros anos da história do cinema (COSTA, Flavia Cesarino. O primeiro cinema: espetáculo, narração, domesticação. São Paulo: Azougue Editorial, 2005, p. 18.). Aqui, o filme interessa não só por conta de todos esses elementos, mas principalmente porque coloca em cena a desintegração do corpo humano produzida por duas máquinas essencialmente modernas: o automóvel e o cinema.

${ }^{114}$ Apesar de, naquela época, ainda ser um objeto muito restrito à elite, para se ter uma ideia, em 1904 havia 8.465 automóveis privados no Reino Unido; dez anos depois o número havia subido para 132.015. Cf. TOULMIN, Vanessa. Electric Edwardians: the story of the Mitchel \& Kenyon collection. Londres: British Film Institute, 2006, p. 178.
} 
“desorganizou”. O curta brinca justamente com o aspecto banal do acidente. A cena é absurda, mas é também de algum modo esperada, tanto no cinema como na cidade.

Segundo Hepworth, produtor do filme Explosão de um veículo motorizado, em uma conferência feita em Londres nos anos 1930, o automóvel usado na filmagem era seu primeiro carro e o homem que o dirige, de quepe branco, é ele mesmo. Na ocasião, ele se lembra que

\begin{abstract}
o filme refletia a concepção popular de automobilismo daqueles tempos, pois o carro era mostrado precipitando-se pela pista à máxima velocidade de 12 milhas por hora, quando subitamente explode e atira seus ocupantes para os céus. (...) Foi um filme muito popular e seu lucro quase pagou pelo carro. (...) $\mathrm{O}$ quepe era absolutamente essencial e era obrigatório se e quando você encontrava outro motorista, que os dois saudassem um ao outro solenemente. ${ }^{115}$
\end{abstract}

É curioso notar que a cordialidade entre os motoristas é oposta ao tratamento que recebem pedestres e policiais.

Se, no filme Explosão de um veículo motorizado, o carro explode antes de chegar perto demais da câmera, em Como é ser atropelado (How it feels to be run over), filme feito pelo mesmo Hepworth em 1900, o automóvel não consegue frear a tempo. O curta, que dura menos de um minuto, mostra, em plano geral, uma estrada rural margeada por densa vegetação. Uma carroça vem de longe, ocupando a faixa da esquerda (como já mandava a lei britânica de trânsito), e sai de cena passando por nós pela direita do quadro. A imagem é coberta por uma nuvem de poeira, rastro de sua passagem. Quando o pó se dissipa, podemos ver um automóvel fazer o mesmo percurso, mas ocupando a faixa da direita, na direção da câmera. Conforme ele se aproxima, em alta velocidade, podemos distinguir um homem ao volante, uma mulher no banco do passageiro e outro homem no banco de trás. Os três gesticulam enfaticamente, como se nos mandassem sair do caminho. O carro chega tão perto que a última coisa que vemos dele é o para-choque. Segue-se uma tela preta, na qual aparecem alguns pontos de exclamação e interrogação, inscritos em branco na própria película. E a seguinte frase, palavra a palavra: "Oh! Mother will be pleased". ${ }^{116}$ Quem teria dito essas palavras irônicas? O motorista, irritado por ter batido o carro? O próprio operador da câmera? Alguém da plateia?

${ }^{115}$ BARKER, W. G.; HEPWORTH, C. M.; PAUL, R. W. Before 1910: Kinematograph experiences. In: Proceedings of the British Kinematograph Society. No. 38. Londres: BKS, 1936, s. p. Disponível em: < http://brianpritchard.com/1910\%20Kinematograph\%20Experiences.htm >. Acesso em: 03/01/2018.

${ }^{116}$ Algo como "Ah! Mamãe ficará contente" (com a batida!). 
Desde o título, o filme propõe que o cinema seja capaz de simular uma experiência. Seu objetivo é mostrar para o espectador como se sente alguém que é atropelado por um automóvel. Como naquele postal francês (figura 31), a expectativa é construída a partir de um carro que avança na direção da câmera, aqui cinematográfica, o que sugere que ele investe também na direção do espectador, que tem seu ponto de vista aproximado ao do operador. É dessa impressão, causada pelo progressivo aumento do veículo no plano, que Como é ser atropelado faz graça. Ao representar aquilo que mesmo os mais crédulos sabem ser impossível de acontecer (um automóvel cinematográfico atropelar o espectador), o filme tematiza uma certa ansiedade urbana. ${ }^{117} \mathrm{O}$ espectador é corporificado pelo filme e este corpo passa a ser parte integrante de um jogo entre imagem e realidade. A atração desse filme, como de muitos outros do período, incluindo Circuito de São Gonçalo, parece estar na capacidade do cinema de mostrar corpos em perigo, seja de modo fantástico e distante ou realista e local.

Segundo Lynne Kirby, que estudou as relações entre a ferrovia e o cinema silencioso nos Estados Unidos, o desejo por ver a tecnologia sair do controle, num misto de prazer e terror, chegou ser responsável, ao longo do século XIX, pela criação e enorme sucesso de espetáculos que encenavam inundações, incêndios, grandes acidentes de trem e outras catástrofes. ${ }^{118}$ Essas violentas atrações, encenadas na emergência da modernidade, "transformavam o choque em espetáculo palatável". ${ }^{119}$ Em nosso filme, o interesse por imagens sensacionais é salientado em um plano em que o espectador pode chegar a roer as unhas. $\mathrm{O}$ choque entre máquina motorizada e paisagem rural, presente em todo o curta, é enfatizado quando o competidor de número seis quase atropela um cachorro que sai de quadro segundos antes que o carro passe por onde ele caminhava tranquilamente. Na figura 36 podemos ver o carro que avança do fundo e o cachorro branco, atravessando o mato que separa a pista dos trilhos de trem, logo antes de quase se chocarem. A imagem serve de símbolo para o triunfo da máquina sobre a paisagem rural.

\footnotetext{
${ }^{117}$ Como vimos no caso do cinegrafista Ortiz Rúbio Alexim, cujo registro derradeiro encerra o filme 70 anos de Brasil: da Belle Époque aos nossos dias (Jurandyr Noronha, 1972), violentamente decapitado pela asa de um avião enquanto o filmava, o operador cinematográfico não desfruta da mesma imunidade que $o$ espectador.

${ }^{118}$ KIRBY, Lynne. Parallel Tracks: the railroad and silent cinema. Durham: Duke University Press, 1997, p. 61,62 .

${ }^{119}$ Ibidem, p. 62.
} 


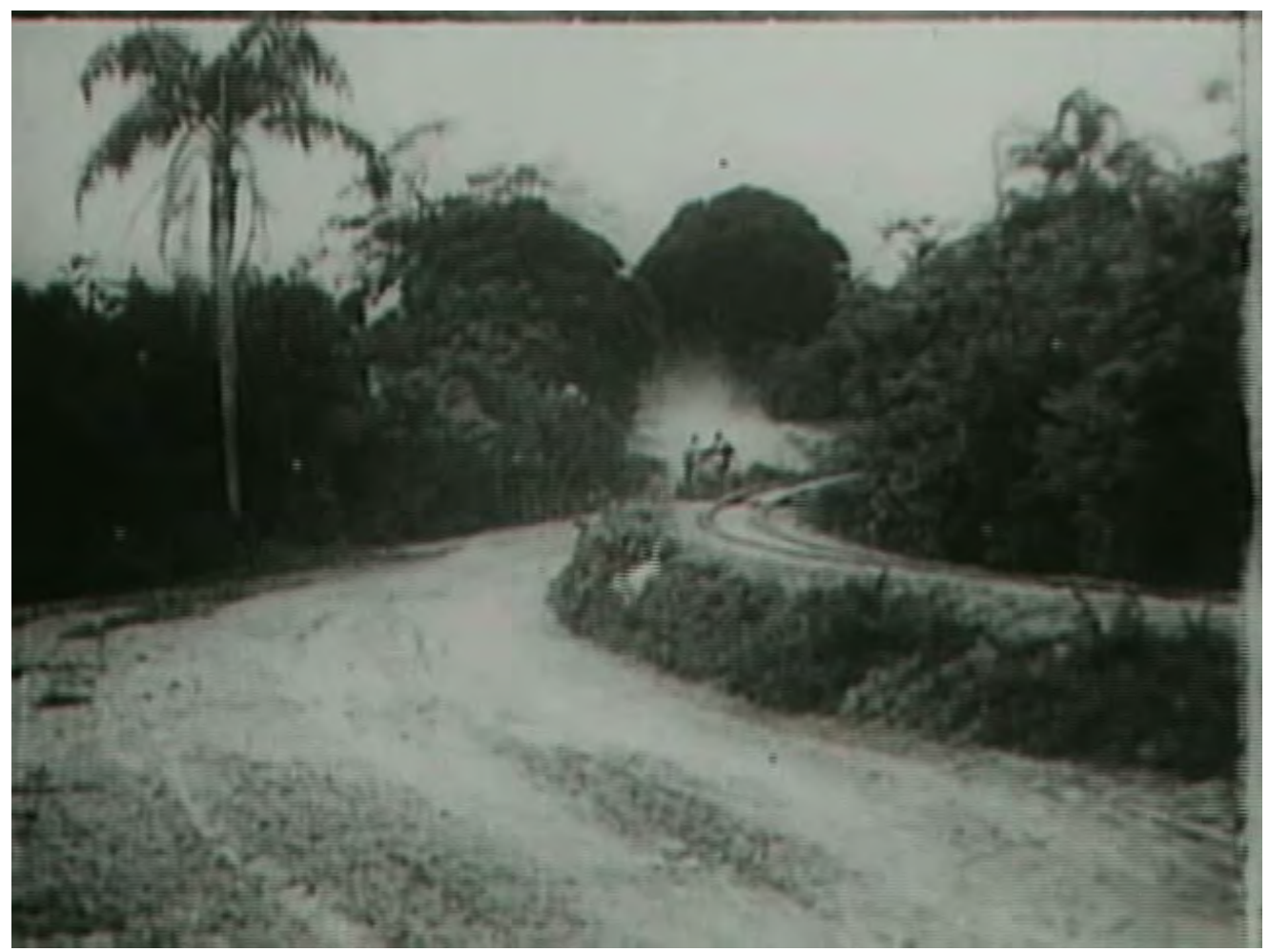

Figura 36 - Circuito de São Gonçalo (1909).

Um animal foi efetivamente morto durante o percurso. Segundo uma reportagem, um dos esportistas "matou um porco que atravessava a estrada, acarretando-lhe esse accidente um grande atrazo, por terem arrebentado tres pneumaticos." ${ }^{20} \mathrm{O}$ caráter esdrúxulo do incidente aponta para o choque entre duas realidades: a do esporte motorizado, urbano, e a da vida rústica, rural. A revista Careta, na semana seguinte ao circuito, publicou algumas ilustrações que brincavam com esse encontro captado pelo filme entre o campo e as máquinas modernas. Um exemplo mostra um carro passando em uma estrada de terra em um ambiente rural. Algumas pessoas observam perto de uma construção simples. Quatro patos aparecem em primeiro plano (figura 37). A legenda diz: “1 Pato - E então?... A civilisação estende-se até nós. Já não são mais só os patos europeus que passam por estes sustos".

\footnotetext{
${ }^{120}$ O circuito de S. Gonçalo. Correio da Manhã. Rio de Janeiro, 20/09/1909, p. 3.
} 


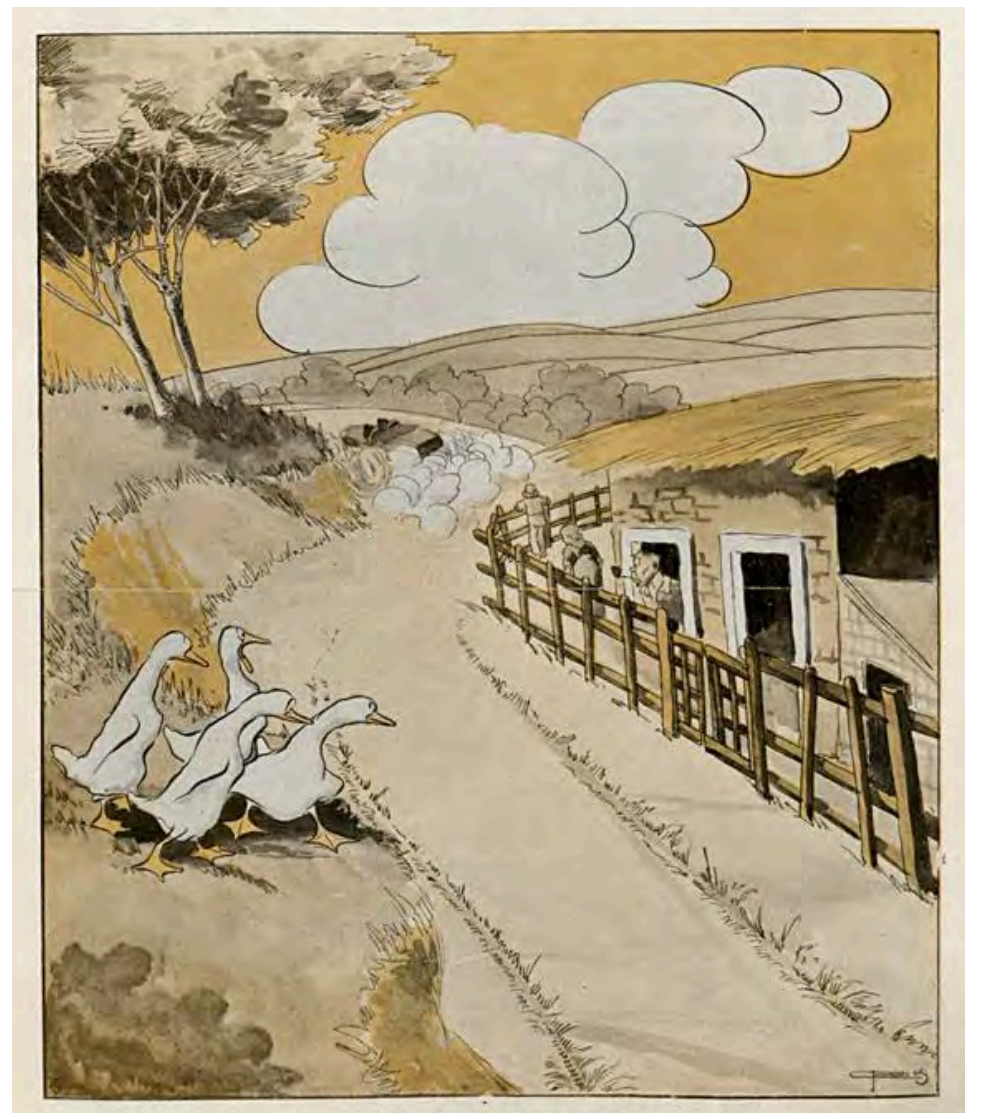

Figura 37 - O circuito de S. Gonçalo. Careta. Rio de Janeiro, 25/09/1909, ano 2, n. 69, p. 11.

O interessante aqui é a relação estabelecida pela charge entre "civilização" e "susto", que aponta para o duplo aspecto tanto do automóvel, como do cinema. Ambas máquinas modernas, o primeiro uniu velocidade e acidente, constituindo um perigo real para motoristas, passageiros e passantes, enquanto o segundo ligou movimento e choque, buscando causar, nos espectadores, alguma excitação sensorial.

Neste ponto, podemos pensar em questão semelhante à que propôs Ismail Xavier sobre a descontração operária (trabalhadores que sorriem para a câmera, crianças que brincam descalças nos arredores da fábrica etc.) no filme Sociedade Anônima Fábrica Votorantim (1922). Em seu artigo sobre o longa, ele aventa a possibilidade de

o caráter monumental do discurso verbal, bem como o da própria retórica dos planos gerais de instalações avançadas do ponto de vista técnico, [estar] sendo minado por tal conjunto de ocorrências que incluem a tranqüila presença de um cão vira latas a se coçar não longe da câmera enquanto o plano geral quer 
dar conta da grandeza e da solenidade da represa que garante energia elétrica para a fábrica. $^{121}$

Em Circuito de São Gonçalo, este descompasso aparece na própria paisagem, como vimos, e é personificado por seus habitantes. Quando o filme mostra um carro parar no pit stop, essa tensão fica clara. Encostados em uma casa rústica, ao fundo, muitas pessoas simples observam a movimentação, de frente para nós. Alguns estão inclusive atrás de uma cerca de madeira e outros, ao sinal da bandeira de um homem fardado, correm para se juntar aos que estão colados às paredes externas da casa (figura 38). Então, em primeiro plano, homens vestidos com guarda-pós correm de um lado para o outro, trombando uns nos outros, enquanto acompanham a chegada do carro.

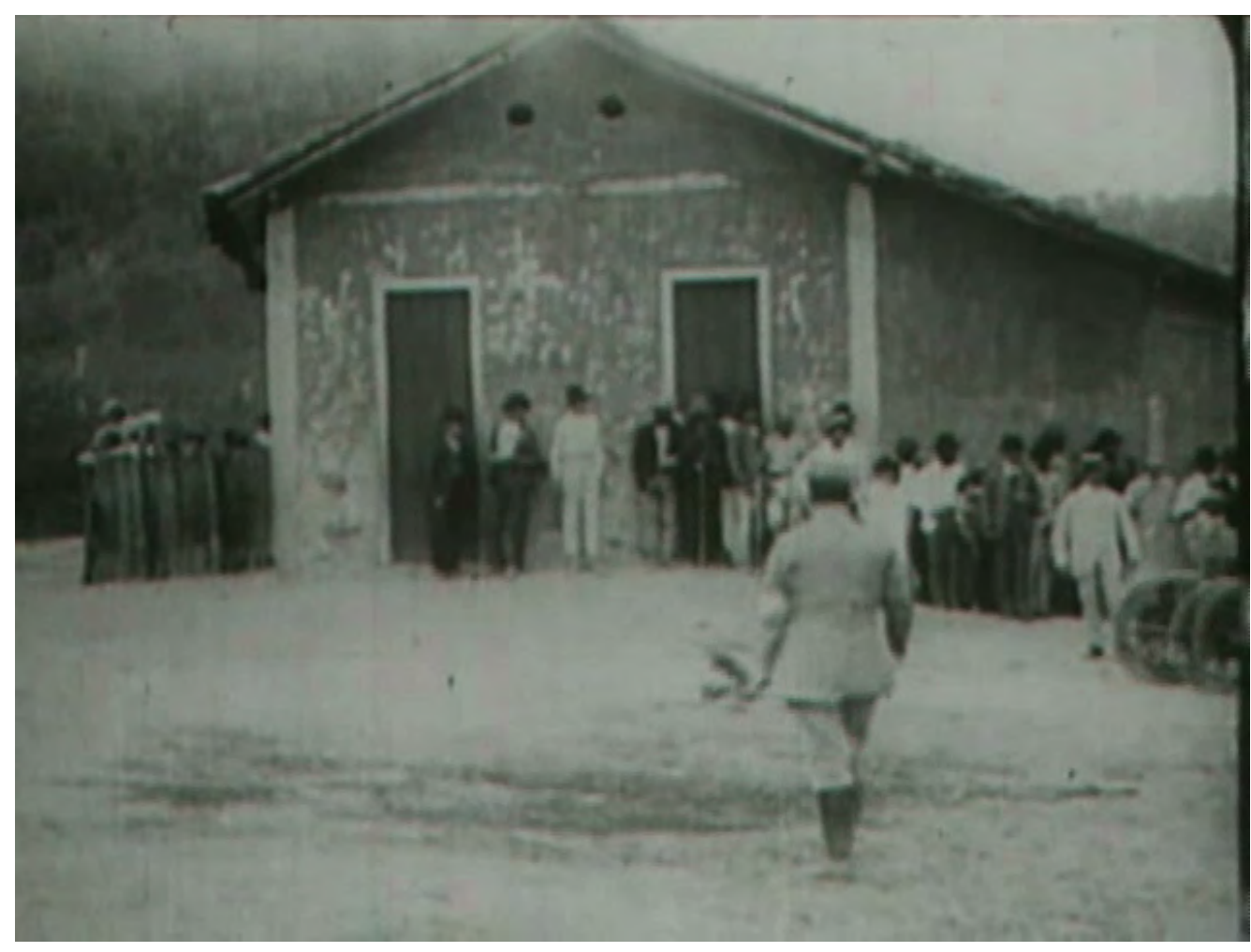

Figura 38 - Circuito de São Gonçalo (1909).

No plano seguinte, vemos apenas o automóvel, mais de perto, cercado por homens - todos brancos e de terno: os populares foram excluídos da imagem. Do potencial perturbador que a presença dos elementos campestres (construções, animais e os próprios campesinos) representa, decorre a disciplina a que são submetidos. Apesar de ocuparem posição

121 XAVIER, Ismail. Progresso, disciplina fabril e descontração operária: retóricas do documentário brasileiro silencioso. ArtCultura, Vol. 11, No. 18, jan-jun 2009, p. 19. 
sempre marginal no quadro, não foram totalmente excluídos da composição, marcando uma presença ambígua, que aponta tanto para a curiosidade que o novo esporte incita, quanto para seu caráter elitista e, portanto, excludente.

\section{A morte de chapéu}

Já comentamos alguns filmes cômicos ligados ao universo do automóvel. Muitas películas desse tipo haviam sido exibidas para as plateias cariocas antes da estreia de Circuito de São Gonçalo. Alguns exemplos são: O cachorro chauffeur (1908) ${ }^{122}$; Estréia de um chauffeur ou Estréia de um automobilista (Débuts d'un chauffeur, Pathé Frères, Georges Hatot, 1906), divulgado como “mordaz crítica aos 'chauffeurs' que nada respeitam, quebrando mostruário de louças, derrubando barracas, enfim, fazendo mil aventuras de elevado espírito cômico"; ${ }^{123}$ Motorista e mulher cocheiro ou Chauffeur $e$ mulher cocheira (Chauffeur et cochère, Pathé Frères, 1909), sobre a "ligação legítima de chauffeur e de mulher cocheira, dá resultado a uma série de cenas de hilariante efeito, nas quais a sogra e o sogro têm interessante parte"; ${ }^{124}$ Circuito de carrinhos de mão ou Circuito... a pé (Le circuit des voitures à bras, Pathé Frères, 1908), “jocosa composição comica, grande parodia ao [segundo] circuito de Dieppe!"; ${ }^{125}$ O sonho de um chofer (The chauffeur's dream, Charles Urban, Walter R. Booth, 1908), descrito como "cômica fantástica em que um pobre chauffeur empreende uma viagem à terra, aos infernos e no espaço, cometendo tantos e tantos desatinos que a própria cara da lua não escapa"126.

Como nenhum deles parece ter sobrevivido ou estar disponível para o visionamento, passaremos a comentar um curta que talvez tenha semelhanças com o último citado. O motorista insano (The '?' motorist ou The mad motorist, Paul's

\footnotetext{
${ }^{122}$ Exibido no Parisiense em 15/05/1908. Cf. Cine Silencioso: Filmes estrangeiros exibidos no Brasil 18961916. Disponível em: < http://mnemocine.com.br/JCB/visualizar.php?id=16027 >. Acesso em: 22/04/2018.

${ }^{123}$ Exibido no Teatro Lírico (06/10/1907) e também em São Paulo, no Teatro Sant'Ana (06/08/1907). Cf. Cine Silencioso: Filmes estrangeiros exibidos no Brasil 1896-1916. Disponível em: < http://mnemocine.com.br/JCB/visualizar.php?id=709 >. Acesso em: 22/04/2018.

${ }^{124}$ Exibido no Cinematógrafo Pathé (12/02/1909) e também em São Paulo, no Iris Theatre (12/04/1910). Cf. Cine Silencioso: Filmes estrangeiros exibidos no Brasil 1896-1916. Disponível em: < http://mnemocine.com.br/JCB/visualizar.php?id=4688 >. Acesso em: 22/04/2018.

${ }^{125}$ CINEMA-Pathé. Jornal do Brasil. Rio de Janeiro, 26/10/1908, p. 12. Exibido no Cinematógrafo Pathé (1908) e pela Empresa Paschoal Segreto (17/11/1908). Cf. Cine Silencioso: Filmes estrangeiros exibidos no Brasil 1896-1916. Disponível em: < http://mnemocine.com.br/JCB/visualizar.php?id=16072 >. Acesso em: 22/04/2018.

${ }^{126}$ Exibido no Parisiense em 09/08/1908, segundo a base de dados Cine Silencioso: Filmes estrangeiros exibidos no Brasil 1896-1916. Disponível em: < http://mnemocine.com.br/JCB/visualizar.php?id=23335 >. Acesso em: 22/04/2018.
} 
Animatograph Works, Walter R. Booth, 1906), realizado dois anos antes pelo mesmo operador, sob a supervisão de R. W. Paul, fez sucesso por construir um universo semelhante aos do francês Georges Méliès, encenando as aventuras fantásticas de um casal motorizado. Vejamos mais de perto este caso, que une o gênero de perseguição com uma espécie de corrida automobilística e é significativo da representação que o cinema dos primeiros tempos fez do automóvel, suas possibilidades e perigos. ${ }^{127}$

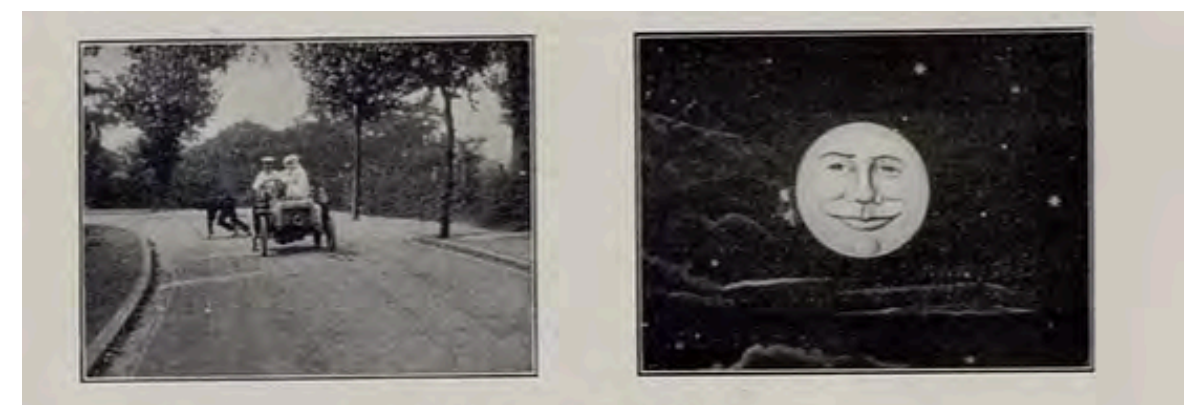

Figura 39 - O motorista insano (1906). ${ }^{128}$

Um plano geral mostra uma rua por onde vem um automóvel em alta velocidade, na direção da câmera. Um homem dirige e uma mulher ocupa o banco do passageiro. Um policial entra em quadro e se coloca na frente do carro, acenando para que parem. $\mathrm{O}$ auto continua seu curso, avançando sobre o policial, que cai no capô do veículo enquanto o casal bate em sua cabeça. O plano seguinte mostra o mesmo carro vindo novamente em nossa direção, mas o policial é agora representado por um boneco, que os motorizados continuam a espancar até que jogam-no para a frente, atropelando-o. Assim que as rodas terminam de passar por cima dele, uma trucagem de parada para substituição traz de volta o mesmo ator de antes. Ele se levanta, tira o pó das calças como se nada fosse e segue correndo atrás do veículo, até perseguidos e perseguidor saírem de quadro. Vemos com clareza o motorista de óculos, quepe e guarda-pó brancos e a passageira, também de branco, com o rosto coberto por um véu. No plano seguinte, o carro reaparece, de costas para a câmera, seguindo na direção de um edifício até que, quando parece que vai se chocar contra a parede, nova trucagem o transforma em um carro cenográfico de modo que agora o vemos de cima, subindo pela parede da construção até sair de quadro pelo alto. Sobre o céu cinza de uma cidade, por meio de uma trucagem de sobreimpressão, voa

\footnotetext{
${ }^{127}$ Utilizamos, para esta análise, a versão digital do filme que faz parte do DVD R. W. Paul: the collected films 1895-1908. British Film Institute.

${ }_{128}$ PAUL, Robt. W. Catalogue of selected animated photograph films. Section B, 1906-7. Londres: Animatograph Depot, 1906, p. 5.
} 
o automóvel branco, numa reprodução em miniatura. O próximo plano mostra, sobre um fundo preto, um panorama com nuvens e algumas estrelas. $\mathrm{O}$ carro surge novamente e roda pelas nuvens de maquete até chegar a um sol sorridente. O carro dá uma volta no astro e depois, levado por um cometa, chega aos aneis de saturno.

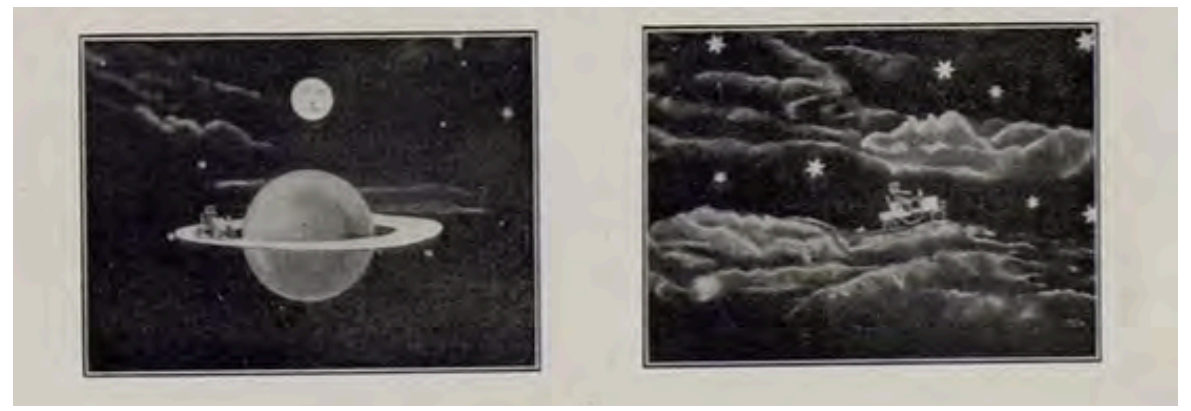

Figura 40 - O motorista insano (1906). ${ }^{129}$

A imagem seguinte mostra várias nuvens subir sobre um fundo preto enquanto o carro cai do topo à base do quadro. Vemos, então, vários telhados de uma cidade sobre um fundo de nuvens brancas. Toda essa sequência espacial tem um tingimento azulado. O automóvel cai em um telhado em primeiro plano. O próximo plano mostra o interior de uma sala onde se lê ao fundo "HANDOVER COURT": é um tribunal. No papel de réu, um garoto que segura um quepe branco. Ele e o juiz discutem até que o garoto joga o chapéu no chão. Alguns segundos depois, um homem, sentado à mesa, aponta para cima. Todos os outros também olham assustados até que o automóvel branco cai no chão e sai de quadro, correndo. Todos vão atrás dele, enquanto sobra o réu, sorrindo. O plano seguinte se passa em um ambiente rural. Pela estrada de terra vem devagar o automóvel, até que ele para no centro do quadro e o motorista salta para olhar a parte de baixo do capô. Será que esse automóvel, que parecia invencível, precisa de manutenção? Será que é mexendo nas peças de seu motor que ele voltará a andar, como um carro qualquer? Entram policial, juiz e mais um homem da cena do julgamento. O policial segura o motorista quando, com nova trucagem, o motorista, a mulher e o carro se transformam em carroça e camponeses. Os três homens gesticulam confusos, o juiz esfrega os olhos, tira os óculos parecendo não acreditar no que vê. É quando outra trucagem transforma o veículo e o casal novamente em carro e personagens de antes. É claro que o automóvel não precisa de uma manutenção tradicional: ele é um automóvel cinematográfico. O carro

129 PAUL, Robt. W. Catalogue of selected animated photograph films. Section B, 1906-7. Londres: Animatograph Depot, 1906, p. 5. 
arranca como se nada tivesse acontecido até sair de cena, o casal acenando feliz para os três homens da lei, enquanto estes retomam a corrida e o filme termina.

A representação das autoridades, sempre estabanadas nos filmes de perseguição e nas comédias silenciosas em geral -, sugere o desprezo à lei em favor das vontades de um motorista egocentrado. Na cena do tribunal aparece um elemento importante: o réu usa um quepe branco, muito semelhante ao do motorista alucinado. Já vimos como esse chapéu era importante para a demonstração de cordialidade entre condutores de automóvel. Seria a cena a representação de um julgamento de outro condutor imprudente? Como Hepworth, R. W. Paul também era um apaixonado pelo automobilismo. E parece que ele foi pego mais de uma vez excedendo limites de velocidade pelas ruas de Londres. ${ }^{130}$ Esse dado biográfico de seu produtor costuma ser lembrado nas tentativas de compreender esse filme. O filme realmente parece expressar um desejo por acelerar o quanto se queira, por onde se queira, sem ninguém pelo caminho.

O que esses filmes parecem discutir por meio de situações fantásticas, é a imprevisibilidade da vida na cidade e a instabilidade de nossos corpos diante desse novo caos que não parava de se propagar. Se estamos vivos agora, nada garante que não estaremos mortos no próximo instante, destroçados por qualquer máquina que passe por nosso caminho. Como explica Ben Singer, os cidadãos das metrópoles viam-se, naquele início de século, diante de uma "esfera pública radicalmente alterada, definida pelo acaso, pelo perigo e por impressões chocantes mais do que por qualquer concepção tradicional de segurança, continuidade e destino autocontrolado."131 A trucagem que substitui corpos por bonecos sem vida, que desmembra e esmaga, não busca esconder-se. Pelo contrário, faz parte da atração desse tipo de filme o uso desses artifícios.

Um espectador do filme, o simbolista russo Andrei Bely, nos deixou sua impressão, em seu artigo "A cidade", de 1907. Depois de descrever algumas cenas que misturam elementos deste e de outros filmes como Viagem através do impossível (Voyage à travers l'impossible, Georges Méliès, 1904), ele diz:

É engraçado, mas na verdade não é nada engraçado. Nem as paredes e a pacata domesticidade podem nos proteger do surgimento do desconhecido, podem? (...) A cidade, que engoliu os campos e agarrou todas as riquezas da terra, é apenas um automóvel suspenso no vazio... Luzes elétricas caem em cascata

\footnotetext{
${ }^{130}$ CHRISTIE, Ian. R. W. Paul: the collected films 1895-1908. British Film Institute: encarte de DVD, sem data, p. 21.

${ }^{131}$ SINGER, Ben. Modernidade, hiperestímulo e o início do sensacionalismo popular. In: CHARNEY, Leo; SCHWARTZ, Vanessa R. (Orgs.). O cinema e a invenção da vida moderna. São Paulo: Cosac Naify, 2004, p. 103-106.
} 
dos outdoors, mas isso é só uma chuva de meteoros piscando através do éter. E o motorista - a Morte de chapéu - está mostrando seus dentes e acelerando em nossa direção. ${ }^{132}$

O que chama a atenção nessa visão macabra do mundo é a volubilidade das coisas e dos corpos. Não somos nada perto de um motorista enlouquecido que encarna a própria morte. Para o literato, segundo o pesquisador russo Yuri Tsivian, ${ }^{133}$ o filme de trucagem era a metáfora perfeita para um mundo moderno perigoso, imprevisível e sem sentido.

Não é à toa que Bely aproxima o filme de Paul e Booth com aquele feito por Méliès dois anos antes. A referência ao universo do prestidigitador francês é clara em $O$ motorista insano, sendo facilmente reconhecida no astro que sorri. Um filme de Méliès que pode ter servido de inspiração direta é O percurso Paris-Monte Carlo em duas horas (Le raid Paris-Monte-Carlo en deux heures, 1905), que faz referência direta a uma corrida de automóveis. Um homem decide encurtar o tempo de uma viagem utilizando um carro. Vários acidentes se sucedem, mas o mais interessante é o primeiro: enquanto enche o tanque em uma oficina, o motorista acaba dando ré por cima de um pedestre. Quando o carro se afasta, vemos que o homem foi prensado e parece uma folha de papel (mais uma vez, um boneco). Várias pessoas se juntam e, com bombas de encher pneus, inflam o corpo até que ele volta ao normal (por meio de algumas trucagens, logicamente). A imagem é hilária. Mas é triste perceber que, no caso de sermos atropelados fora do cinema, não há bomba que nos traga a vida de volta.

Em $O$ motorista insano, reina o nonsense em um mundo em que o automóvel pode tudo: atropelar autoridades, escalar prédios, correr pelo espaço sideral, dar voltas nos astros, transformar-se quantas vezes quiser e, principalmente, sair sempre ileso às leis de trânsito e ao bom senso. Mesmo quando o carro quebra e parece que estamos diante de um veículo real, o filme nos lembra que ele é feito de imagem - e a imagem se transforma num piscar de olhos.

O automóvel, símbolo do individualismo moderno, ao mesmo tempo em que permite que o corpo humano realize o impossível, para além de suas capacidades comuns de mobilidade e velocidade, é também o responsável por desmembrar, esmagar, decapitar. Para esses filmes de mais de cem anos atrás, quando o corpo humano encontra a máquina sobre rodas, duas coisas podem acontecer: ou ele ganha super poderes e passa por cima do que e de quem se fizer obstáculo, ou ele é o próprio obstáculo que precisa ser

\footnotetext{
${ }^{132}$ BELY apud TSIVIAN, Yuri. Early cinema in Russia and its cultural reception. Chicago e Londres: The University of Chicago Press, 1998, p. 150-151.

${ }^{133}$ TSIVIAN, Yuri. Op. cit., p. 149-150.
} 
desintegrado para que a máquina cumpra seu trajeto. Todos estes filmes sobre automóveis parecem tematizar, enfim, a instabilidade do corpo humano na cidade moderna em cujas ruas o reina o acaso, que tanto interessa quanto gera repulsa.

\section{A catástrofe como atração}

Cinema e automóvel, duas máquinas modernas, serviram de plataforma para a exibição da elite carioca, por meio dos corsos, das corridas e das imagens produzidas sobre eles. As imagens, tanto cinematográficas como fotográficas, foram essenciais nesse processo, por perpetuar a aparência que a elite buscava divulgar de si. Mostrar-se pilotando máquinas motorizadas e ver-se na tela parecem ter sido modos de diferenciação social bastante significativos. Segundo o historiador Nicolau Sevcenko,

\footnotetext{
ser identificado como moderno [implica] necessariamente algum modo de relação com a tecnologia e a atitude individualista (...) [e] essa identificação não prescinde também de uma obrigatória associação com símbolos cosmopolitas, em especial aqueles que conotam origem europeia ou norteamericana, consolidando a prática chic de ser snob. ${ }^{134}$
}

Circuito de São Gonçalo, filme de caráter local, deu a oportunidade da elite carioca ver-se nas telas associada a uma das máquinas mais modernas de seu tempo, o automóvel. Revelando uma indissociação entre velocidade e acidente, a obra enfatiza os perigos inerentes à corrida automobilística por meio de diferentes escolhas: os enquadramentos, a montagem e a própria seleção do que mereceu ser filmado. Deste modo, o destaque que o curta dá à catástrofe, mesmo sem mostrar o momento exato em que acontece, contribui para o desejo por desastres que vinha sendo construído na imprensa.

Apesar do circuito ter contado com um sistema de comunicações por telegramas e telefones especialmente montado para manter o público informado das "peripécias" da corrida, em tempo real, ${ }^{135}$ o filme deu aos espectadores do evento (tanto pagantes como não pagantes), dois dias depois, acesso visual aos trechos perigosos do percurso, de modo análogo ao que os cartões postais e as imagens publicadas na imprensa costumavam fazer. Como quem escolhe porções da paisagem para examinar de perto através de um binóculo, os responsáveis pela produção do filme escolheram enfatizar, além do público

\footnotetext{
${ }^{134}$ SEVCENKO, Nicolau. A capital irradiante: técnica, ritmos e ritos do Rio. In: História da vida privada (v. 3) - República: da Belle Époque à Era do Rádio. São Paulo: Cia. das Letras, 1998, p. 533-534.

${ }^{135}$ CORRIDA de automoveis. Correio da Manhã, 19/09/1909, p. 4.
} 
considerado distinto, imagens "de sensação", ou seja, imagens que, por meio da visão, buscavam aproximar o espectador das reações corporais que o tráfego motorizado podia causar.

A máquina representava, para alguns, o prestígio da associação com a modernidade. Para eles, até a possibilidade de acidentes aponta para a distinção social: não é qualquer um que coloca um objeto caríssimo, importado, em risco e ainda pode divertir-se com isso. Para outros, a grande maioria da população, aqueles que eram pedestres na cena urbana, o automóvel podia ser justamente um símbolo da desigualdade. E o acidente, para as pessoas sem posses, podia ter um significado bastante distinto. Alguns anos antes do circuito, em 1904, durante o episódio que ficou conhecido como "revolta da vacina", os signos da modernidade, cada vez mais espalhados pela cidade em crescimento, foram alvo do levante da população durante a campanha de vacinação contra a varíola. Segundo Sevcenko, o homem pobre foi, naquele momento,

\begin{abstract}
capaz de pressentir a presença do poder que o aflige nos seus menores sinais: na luz elétrica, nos jardins elegantes, nas estátuas, nas vitrines de cristal, nos bancos decorados dos parques, nos relógios públicos, nos bondes, nos carros, nas fachadas de mármore, nas delegacias, agências do correio e postos de vacinação, nos uniformes, nos ministérios e nas placas de sinalização. Tudo que o constrange, o humilha, o subordina e lhe reduz a humanidade. Eis os seus alvos, eis o que desperta sua revolta, e o seu objetivo é assumir e afirmar, ainda que por um gesto radical, ainda que por uma só e última vez, a sua própria dignidade. ${ }^{136}$
\end{abstract}

Ao que parece, a maior parte da imensa multidão que compareceu à corrida não fazia parte do público pagante. Enquanto políticos e membros da elite se concentraram, seguros, nos camarotes e outras seções da arquibancada, posicionada em frente ao ponto de partida e chegada dos carros, vários grupos de pessoas, provavelmente cidadãos de São Gonçalo e região, caminharam pela estrada de terra que serviu de pista, colocandose em risco. Assim como os operadores cinematográficos, provavelmente aquelas pessoas foram até lá em busca da possibilidade de presenciar situações de perigo ou mesmo testemunhar batidas automobilísticas, atração para a qual não era preciso pagar ingresso. Essa busca por imagens catastróficas aponta para uma ambivalência estrutural daquele espetáculo: o acidente, inseparável da velocidade, representa tanto a futilidade da

${ }^{136}$ SEVCENKO, Nicolau. A Revolta da Vacina: Mentes insanas em corpos rebeldes. São Paulo: Cosac Naify, 2010, p. 96. 
brincadeira dos ricos como a destruição de um dos mais fortes símbolos de opressão que ganhava espaço nas ruas da cidade.

O interesse pela corrida de São Gonçalo e pelas imagens produzidas sobre ela parece não residir, portanto, apenas na visibilidade ou na velocidade, mas também, justamente, no perigo implicado nesse esporte elitista. Longe de serem ocorrências inesperadas ou imprevistas, os pequenos desastres geraram expectativa e parecem ter sido alvo de grande atenção. Acusado de "catastrofista", ${ }^{137}$ Virilio estreitou a relação entre máquina e acidente ao afirmar o seguinte: "Inventar a embarcação à vela ou o navio a vapor é inventar o naufrágio. Inventar o trem é inventar o acidente do descarrilhamento. Inventar o carro de passeio é produzir o engavetamento na autoestrada." ${ }^{138}$ Nesse sentido, as relações entre velocidade e acidente, modernidade e perigo e, enfim, progresso e catástrofe, são vínculos inerentes à atração que o filme representou naquele contexto.

${ }^{137}$ SANTOS, Guilherme Soares dos. "Minha língua estrangeira é a velocidade, é a aceleração do real". Entrevista com Paul Virilio. Le Monde Diplomatique Brasil. Disponível em: $<$ http://diplomatique.org.br/minha-lingua-estrangeira-e-a-velocidade-e-a-aceleracao-do-real/>. Acesso em: 20/05/2017.

${ }^{138}$ VIRILIO, Paul. The original accident. Cambridge, Malden: Polity Press, 2007, p. 10. 


\section{Segundo capítulo}

\section{Espectadores em cena: mapeamento dos simuladores cinematográficos de viagem brasileiros}

\section{Porta aberta}

O Museu da Imagem e do Som do Rio de Janeiro guarda quase cem mil fotografias. Uma delas, captada em um dia qualquer entre 1903 e 1910, mostra a Rua Pedro I, vista de algum ponto da Praça Tiradentes, no centro da então capital federal (figura 41). A imagem é uma das inúmeras instantâneas registradas por Augusto Malta, fotógrafo oficial da prefeitura, posição na qual se manteve por mais de 30 anos. Na foto, vemos dois dos vários teatros da região. Um está no fim da rua. $\mathrm{O}$ outro, o Teatro Carlos Gomes, aparece na calçada direita da mesma via. O estabelecimento sofreu um incêndio 1929 e, hoje, suas instalações são abrigadas por um edifício art déco que substituiu a construção de esquina que vemos no centro da imagem, cujo endereço é Praça Tiradentes, número 19.

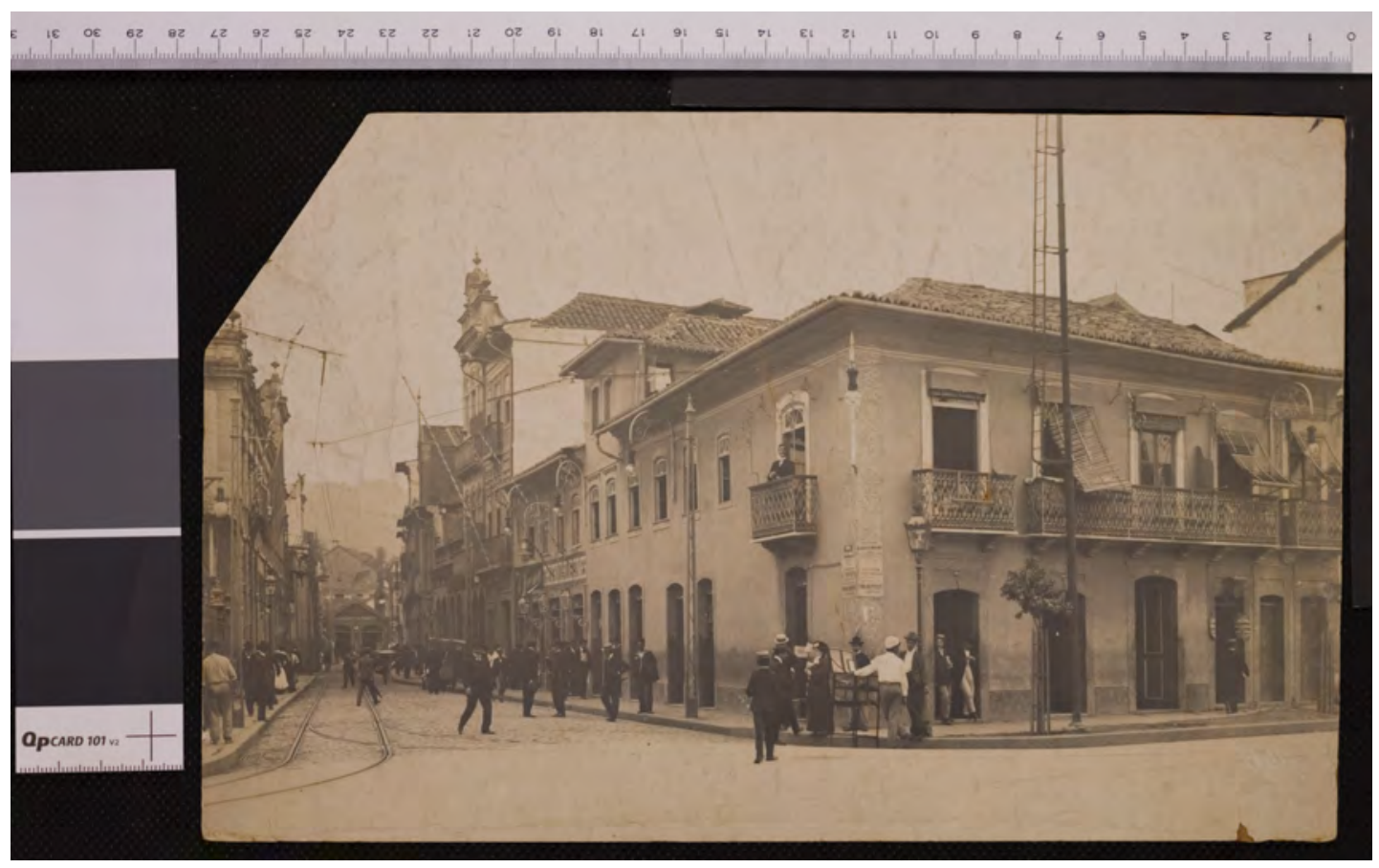

Figura 41 - Vista para a Rua Pedro I tomada da esquina com a Praça Tiradentes, 1903-1910. Coleção Augusto Malta. Acervo FMIS/RJ. 
Olhando mais de perto, a alguns metros da esquina, há uma porta. Na frente dela, fragmentos da silhueta de alguém (figura 42). Não parece ser a entrada de uma residência, já que em cada batente está pregada uma placa na qual pode-se ler algumas palavras: "AS VENCEDORAS // EMPREZA DE [ilegível] // PARA A // CAPITAL [ilegível] // NICTHEROY”. Se o anúncio é enigmático, o objeto que encima a porta é mais curioso ainda: talvez um automóvel em miniatura, talvez um vagãozinho de trem ou bonde.

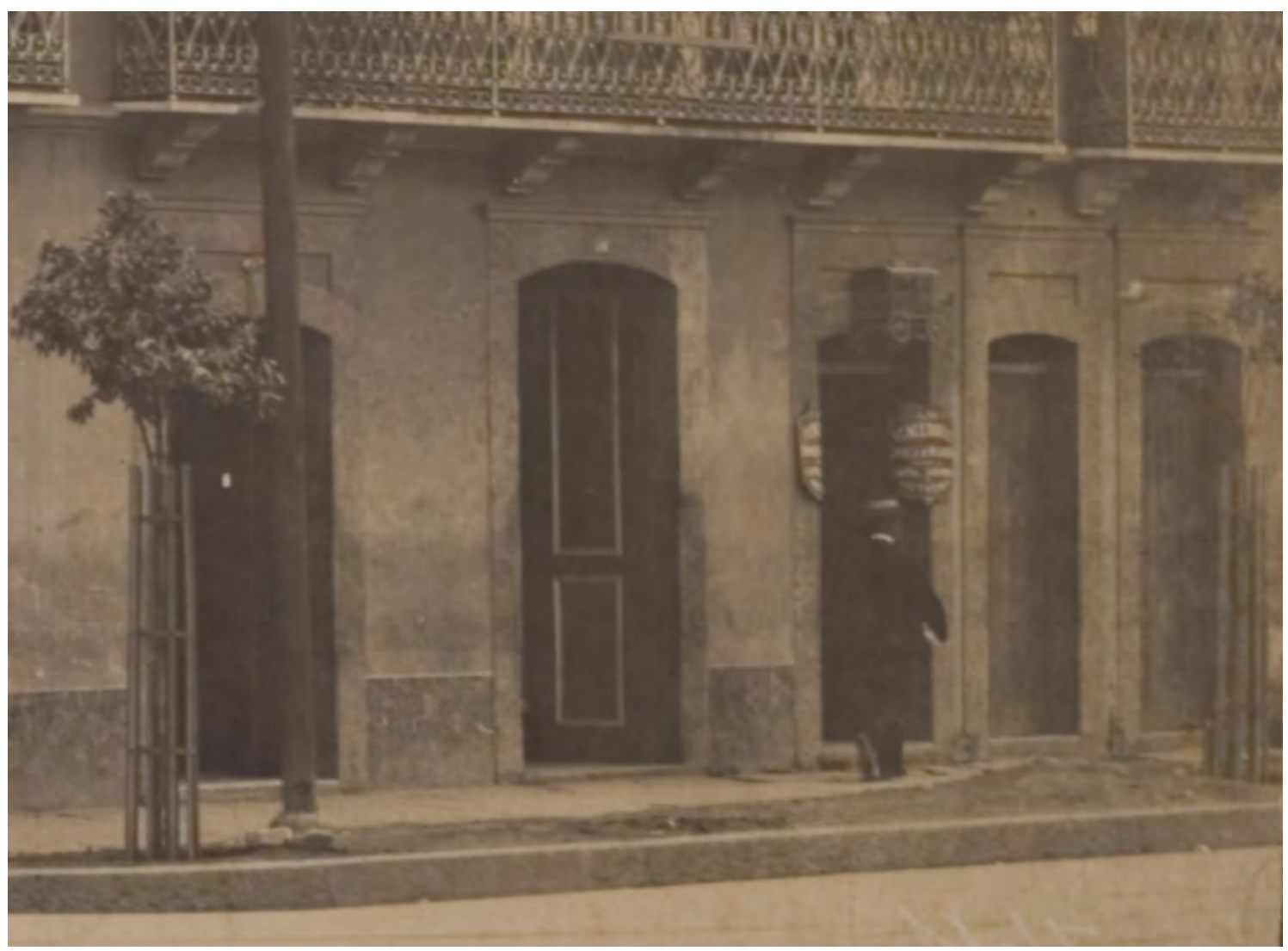

Figura 42 - Vista para a Rua Pedro I tomada da esquina com a Praça Tiradentes, 1903-1910 (detalhe).

Coleção Augusto Malta. Acervo FMIS/RJ.

A porta está aberta. Para nós, ela é um retângulo escuro, área opaca. Da pessoa - que se confunde com o fundo preto -, só imaginamos o corpo ligando os pontos entre um chapéu, um colarinho branco, uma sola de sapato e os contornos de uma perna e de um braço.

Desde os filmes realizados pela equipe de Thomas Edison no estúdio Black Maria, inaugurado em 1893 em Nova Jersey, nos Estados Unidos, o primeiro cinema fez surgir objetos, personagens e criaturas os mais diversos em frente a fundos escuros. Os filmes de "danças serpentinas" (como A dança da serpentina, Serpentine dance, Edison, 1896), por exemplo, mostram largas porções de tecido em movimento, multicoloridas, 
manipuladas por bailarinas cujo corpo parece dissolver-se naquela corrente. Por meio de trucagens como a de sobreimpressão e a de parada para substituição, essas aparições muitas vezes se multiplicam e se transformam. É o caso de muitos filmes produzidos no estúdio de Georges Méliès, construído em 1897 nas proximidades de Paris, na França. Alguns exemplos são A lanterna mágica (La lanterne magique, Georges Méliès, 1903), no qual a tela preta serve de superfície para a projeção de uma lanterna mágica gigante; O melômano (Le mélomane, Georges Méliès, 1903), no qual o fundo escuro se transforma em partitura musical cujas notas são marcadas por réplicas da cabeça do próprio prestidigitador; e O homem da cabeça de borracha (L'homme à la tête de caoutchouc, Georges Méliès, 1901). Neste último, Méliès interpreta uma espécie de cientista maluco que usa um fole para inflar uma cópia de sua própria cabeça. O truque acontece justamente em uma porção escura do quadro, emoldurada pelo batente de uma porta (figuras 43 e 44).
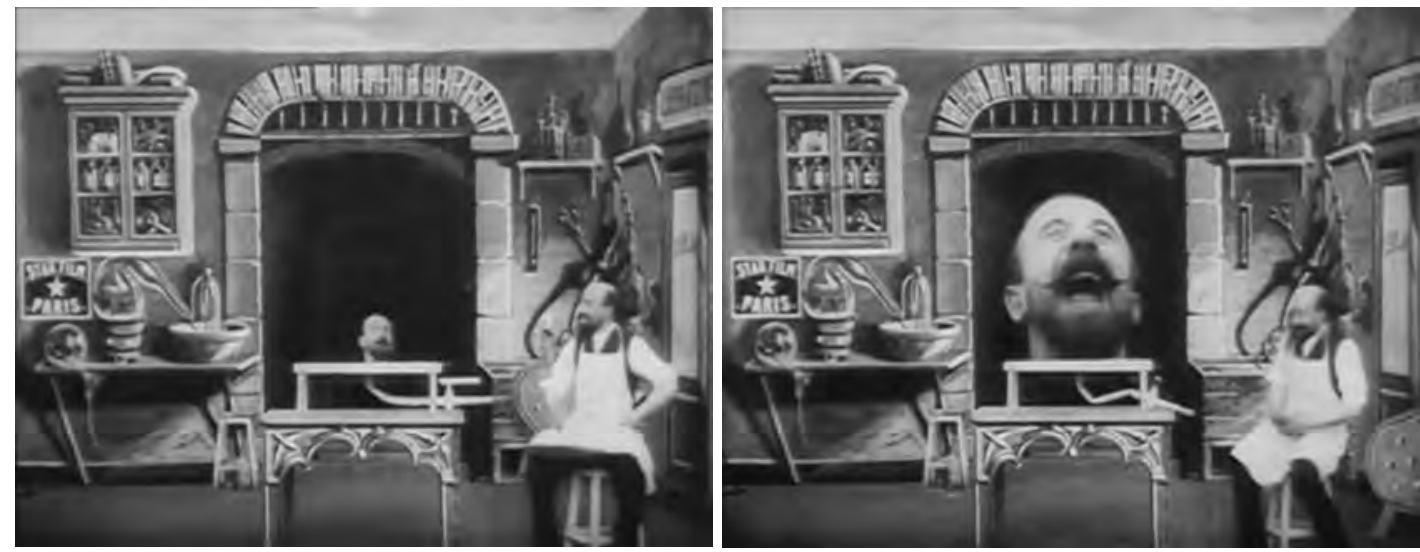

Figuras 43 e 44 - O homem da cabeça de borracha (L'homme à la tête de caoutchouc, Georges Méliès, 1901).

Voltemos à fotografia de Malta. O interior oculto da portinha talvez esconda uma experiência cinematográfica quase totalmente desconhecida entre nós, a dos simuladores cinematográficos de viagem. Se a esquina que aparece em primeiro plano é o número 19 da Praça Tiradentes, aquela entrada talvez correspondesse ao número 27. Foi neste endereço que, segundo alguns anúncios publicados em jornais, a partir de 20 de março de 1907, os cariocas puderam tomar parte em uma atração do tipo, chamada Auto-Tours (figura 43). 


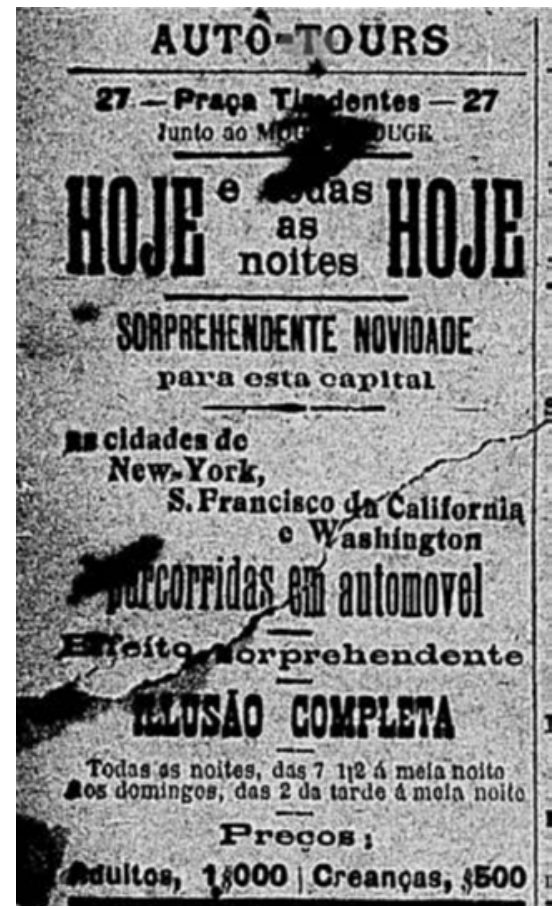

Figura 43 - Correio da manhã, 30/03/1907, p. 8.

Os Auto-Tours foram aparelhos de exibição cinematográfica semelhantes aos Hale's Tours and Scenes of the World, que consistiam em pequenas salas de cinema decoradas para parecer com vagões de trem. A atração foi exibida pela primeira vez em maio de 1905, no parque de diversões Electric Park, na cidade de Kansas, nos Estados Unidos. ${ }^{139}$ O objetivo era fazer o espectador sentir-se como se estivesse viajando, sem sair do lugar. Para construir essa experiência, os filmes eram acompanhados pelo balanço dos assentos, efeitos sonoros e ventiladores que simulavam o vento que entraria pelas janelas dos vagões em uma viagem real. Nos anos seguintes, a atração se espalhou por diferentes países, assumindo diversas formas de simulação além do trem, como as viagens de carro, bonde e navio, tendo desaparecido em meados dos anos $1910 .^{140}$

A ilusão de participar de uma viagem já começava normalmente do lado de fora do prédio, que replicava a fachada de uma estação de trem. Já no interior da sala, o realismo da atração provinha da complexa combinação entre elementos reais e virtuais. Nos simuladores, ao contrário, os presentes eram estimulados a olhar para o cenário e

139 GUNNING, Tom. The world as object lesson: cinema audiences, visual culture, and the St. Louis World's Fair, 1904, Film History 6, no. 4, 1994, p. 440-441.

${ }^{140}$ Este sumário foi elaborado com base em diferentes descrições dos Hale's Tours, que podem ser encontradas em: FIELDING, 1983, p. 116-130; MUSSER, 2008, p. 429-430; RABINOVITZ, 2012, p. 6695. 
interagir uns com os outros e com os atores que eventualmente fizessem parte da encenação.

A natureza híbrida dos simuladores exige que, para serem compreendidos, devam ser vistos como parte tanto da história do cinema, como da história das thrill rides. ${ }^{141} \mathrm{~A}$ historiografia do cinema teve problemas em relação ao status de puro entretenimento que essas atrações pareciam ter tido. Para historiadores que buscavam elevar o cinema a uma forma de arte (principalmente aqueles que produziram seus estudos nos anos 1950 e 1960), a aproximação que os simuladores têm com o parque de diversões e o circo justifica sua quase exclusão dessas pesquisas. Segundo Philippe Gauthier, até recentes estudos alterarem a historiografia do cinema, a abordagem vinha sendo guiada pela sala de cinema "tradicional" como o espaço institucional do que seria o objeto de estudo privilegiado por essa disciplina. Tudo o que estava fora desse espaço foi, portanto, desconsiderado. ${ }^{142}$ A conexão que os Hale's Tours tinham com as classes baixas foi outro motivo para sua exclusão das histórias do cinema.

Os tours simulados, assim como no primeiro cinema em geral, são definidos pelo programa de variedades, mas com uma especificidade: a seleção dos filmes obedecia, é claro, ao objetivo da atração, que era imitar uma viagem. Na tela, que simulava uma janela para o exterior do veículo, os espectadores assistiam a filmes de um dos gêneros mais populares do primeiro cinema, o travelogue, ou filme de viagem. Esses filmes, geralmente de curta metragem, lidavam com formas diversas que iam desde vistas de cidades distantes até filmes de ficção. ${ }^{143}$ Eles mostravam metrópoles famosas, povos considerados exóticos e outras imagens ligadas ao mundo da viagem para um público que começava a ser atraído pelo turismo. Segundo Schvarzman,

o filme de viagem cria uma nova dialética da distância e proximidade, aproximando o distante, tanto do ponto de vista geográfico quanto das diferenças que acaba por dissolver pelo espetáculo e pelo próprio consumo, transformando os lugares em mercadorias genéricas. ${ }^{144}$

\footnotetext{
141 Termo de difícil tradução. Significa algo como "passeio emocionante" e aqui tem o sentido de atração de parque de diversões.

${ }_{142}$ GAUTHIER, Philippe. The movie theater as an institutional space and framework of signification: Hale's Tours and film historiography. In: Film History 21, no. 4, 2009.

143 MUSSER, Charles. The travel genre in 1903-1904: moving towards fictional narrative. In: ELSAESSER, Thomas (Ed.). Early cinema: space, frame, narrative. British Film Institut, 2008, p. 123.

${ }^{144}$ SCHVARZMAN, Sheila. Travelogue e cavação no Brasil pitoresco de Cornélio Pires. In: PAIVA, Samuel; SCHVARZMAN, Sheila. (Orgs.). Viagem ao cinema silencioso do Brasil. Rio de Janeiro: Beco do Azougue, 2011, p. 49.
} 
Essa produção estava ligada a outras formas de consumo de imagens de viagem que se proliferavam na época, como conferências ilustradas da lanterna mágica, exposições internacionais, panoramas e dioramas, estereoscópios e cartões postais.

Um dos subgêneros mais importantes do travelogue foi o filme de viagem fantasma (phantom ride, na bibliografia em língua inglesa), que surgiu já no final do século XIX. Esses filmes eram produzidos a partir da dianteira ou traseira de veículos em movimento, como carros, metrô e, principalmente, trens. Os trilhos que apontam para o horizonte, os postes telegráficos que passam rapidamente e todos os outros objetos em quadro, que servem de marcação para o fluxo do movimento, sugerem para o espectador uma posição especial: a de passageiro ${ }^{145}$ da viagem representada na tela. E é nos simuladores de viagem que essa posição é privilegiada ao máximo.

Para explicar a forma específica do primeiro cinema, Tom Gunning introduziu, nos anos 1980, a expressão "cinema de atrações", cujo objetivo era o de descrever os filmes e o modo de vê-los até o ano de 1906, quando então o cinema passaria a se organizar cada vez mais em função da tarefa de narrar. O cinema de atrações solicita constantemente a atenção do espectador apresentando situações que têm como foco mais os corpos em cena e menos suas motivações psicológicas. ${ }^{146}$ Segundo ele, em vez de desenvolver histórias, os primeiros filmes "enfatizam o estímulo direto do choque ou surpresa". ${ }^{147}$ Ou seja, seria um cinema que mostra mais do que narra.

O primeiro cinema é um outro cinema, o que implica um outro espectador. Este cinema talvez tenha tido sua experiência mais radical justamente nos Hale's Tours, pois o endereçamento direto ao público ganha, aqui, o sentido de foco da experiência cinematográfica. O espanto, ideia comumente usada por Gunning para descrever a estética de atrações, está diretamente ligado ao filme de viagem e seu sujeito fisicamente estimulado, em oposição ao espectador contemplativo do cinema posterior, narrativo. Os simuladores de viagem articulam uma contradição: a desmaterialização do corpo na viagem cinematográfica (ou seja, a ilusão de viajar sem sair do lugar) e sua simultânea materialização no espaço cenográfico, através da ênfase nas sensações corporais. ${ }^{148}$

\footnotetext{
${ }^{145}$ Foi o pesquisador Charles Musser que cunhou a expressão “espectador como passageiro", viewer-aspassenger, no original (MUSSER, 1990, p. 429).

${ }_{146}$ GUNNING, Tom. The cinema of attractions: early film, its spectator and the Avant-Garde. In: ELSAESSER, Thomas. (Ed.) Early Cinema: Space, Frame, Narrative. London: British Film Institute, 1990, pp. 56-57.

147 Ibidem, p. 59.

${ }^{148}$ RABINOVITZ, Lauren. 'Bells and Whistles': The Sound of Meaning in Train Travel Film Rides. In: ABEL, Richard; ALTMAN, Rick (Eds.). The Sounds of Early Cinema. Bloomington: Indiana University Press, 2001, p. 167.
} 
É só por meio de poucas imagens, informações marginais e alguma imaginação que podemos buscar aproximação com qualquer experiência espectatorial, ainda mais quando se está tão distante no tempo. Como o material acerca dos simuladores cinematográficos de viagem brasileiros é muito escasso, apresentamos aqui um mapeamento de suas diferentes versões e temporadas, recorrendo inclusive a descrições da atração em outras cidades como São Paulo e Porto Alegre. Começaremos com o Ferro Carril Asiático, simulador panorâmico, que buscava emular uma viagem ferroviária por meio de paisagens pintadas em longas telas; passaremos aos simuladores propriamente cinematográficos Auto-Tours e Cinema Automóvel; e terminaremos com a análise de um filme do tipo viagem fantasma. Na impossibilidade de adentrar a porta da Praça Tiradentes, escolhemos encarar a escuridão, tateando pelas bordas, por meio da investigação de algumas poucas pistas. ${ }^{149}$

\section{Viagem instrutiva}

Segundo as fontes anteriormente consultadas por aqueles que dedicaram poucas palavras ao tema, ${ }^{150}$ o Ferro Carril Asiático teria passado apenas pela cidade do Rio de Janeiro e permanecido em funcionamento de fevereiro a setembro de 1907. Agora, a partir do exame de periódicos da época, sabemos que, na verdade, a atração teve diferentes temporadas em São Paulo e Rio de Janeiro, que duraram, no total, dois anos. Primeiro ele passou por São Paulo, onde se instalou na Rua Onze de Junho, número 8, no edifício do antigo Frontão Paulista, de cerca do começo de abril ao fim de maio de 1906. O Frontão, local que já avisa sido arena de jogos esportivos, parece ter sido considerado um ambiente cujos frequentadores faziam parte da elite paulistana.

Foi só depois que a atração foi para o Rio de Janeiro, instalando-se no Pavilhão Internacional (Avenida Central, 154) empresariado por Pascoal Segreto. Lá permaneceu de cerca de julho de 1906 até abril de 1908. Primeiro (de julho de 1906 até janeiro de 1907) exibiu o programa "Viagem à Terra Santa" e, depois (de cerca de fevereiro a

\footnotetext{
149 Justamente por conta do pouco material encontrado acerca dos simuladores, algumas análises aqui apresentadas já foram publicadas, de modo resumido, em artigo resultado de nossa pesquisa de Iniciação Científica. Cf. DI GIACOMO, Carolina Azevedo. O espectador como passageiro: os simuladores de viagem do primeiro cinema no Brasil (1906-1908). Vivomatografías. Revista de estudios sobre precine y cine silente en Latinoamérica, No. 1, Dezembro 2015. Disponível em: < http://www.vivomatografias.com/index.php/vmfs/article/view/11 >. Acesso em: 20/07/2019.

${ }^{150}$ GONZAGA, Alice. Palácios e poeiras: 100 anos de cinema no Rio de Janeiro. Rio de Janeiro: Record/Funarte, 1996, p. 276; ARAÚJO, Vicente de Paula. A Bela Época do Cinema Brasileiro. São Paulo: Editora Perspectiva, 1976, p. 194.
} 
setembro de 1907), a "Viagem à Volta do Mundo". Em seguida, sob o nome de Estrada de Ferro Mundial (de outubro de 1907 até abril de 1908), no mesmo Pavilhão Internacional, foram realizadas as chamadas "Viagens à volta do mundo em 25 minutos", que iam de Buenos Aires ao Japão.

Encontramos cerca de dez artigos acerca da passagem do Ferro Carril Asiático por São Paulo, naqueles meses de abril e maio de 1906. A primeira delas já vale a pena ser citada: um longo texto não assinado no Correio Paulistano, publicado um dia depois da estreia da atração na cidade. O novo divertimento é descrito como "o 'great-attraction' do nosso público", ${ }^{151}$ o que já mostra algum desejo de equiparar-se à modernidade estrangeira que será o tom de todo o texto. Depois de listar os lugares que o passeio mostrava, o texto segue:

E dizer-se que o espectador, viajante ou quer que seja, munido de um bilhete de $1^{\text {a }}$. ou $2^{\mathrm{a}}$. classe, adquirido pela ninharia de tres ou dois mil réis, vencerá toda essa immensa extensão de oito mil leguas refestelado commodamente num comboio que o transportará por sobre rios e valles, rasgando ventre das montanhas, e penetrando povoações numa velocidade phantastica de 96.000 kilometros por hora, ou sejam 1.600 por minuto!

É espantoso, mas é verdade!

Ao leitor parecerá que tratamos de uma das celebres narrativas das Mil e uma noites, deixando a perder de vista as viagens maravilhosas de Julio Verne. (...) Entra a pessoa na moderna Babylonia da rua Onze de Junho, que foi o rink e foi frontão, e encontra-se de um momento para outro na velha gare de Kaifa, ao pé de Monte Carmelo. Adquire à entrada o seu bilhete de excursão e na sala de espera, de $1^{\mathrm{a}}$. ou $2^{\mathrm{a}}$. classe, de conformidade com a categoria da passagem, aguardará o comboio, que chegará com uma pontualidade britannica, de acordo com o respectivo horário. As salas são espaçosas e confortáveis. $\mathrm{Na} 1^{\mathrm{a}}$. classe, principalmente, o excursionista encontrará todas as commodidades necessarias, mobiliario fino, puffs, espelhos e, num plano superior, mesinhas para libações avulsas.

A um dado signal, os passageiros se encaminharão para o embarcadouro, onde estará encostado o comboio, de tamanho natural, composto de locomotiva, carro de bagagens e correio, tres carros-salões de $1^{\mathrm{a}}$. classe, pintados interiormente das côres nacionaes, brasileira, portugueza e italiana, e finalmente, dois outros vagões de $2^{\mathrm{a}}$. classe, todos illuminados a luz eletrica. Embarcados os excursionistas e recebidos os bilhetos pelo guarda-trem, porse-á o comboio em movimento.

Começa a illusão, que é a mais perfeita possivel, e que aumenta à proporção que o comboio ganha distancia.

O viajante ouve distinctamente o resfolegar da locomotiva galgando declives, sente o rangido aspero das rodas nas curvas e a trepidação que o sacode todo, emquanto pelas janellinhas de venezianas suspensas se lhe descortina aos olhos o panorama estupendo de montes escalvados, campinas forradas de vegetação atrophiada, planicies estereis e a ruinaria das velhas cidades, aldêas e povoados da Terra Santa. (...)

${ }^{151}$ VIAGEM à Terra Santa. Correio Paulistano, São Paulo, 04/04/1906, p. 4. 
Depois vem a cidade de Tiberiades e as ruinas de Sephoris, que se observa logo apos a passagem de um tunnel (...) e finalmente Jaffa, o ponto terminal da linha. E depois de meia hora de uma viagem aprazivel através de terras extranhas que infundem no espirito um mysticismo salutar, despertando reminiscencias da patria e da familia, acha-se o excursionista onde? Em Jaffa dirão... Não, senhor. Na immensa Babylonia da rua Onze de Junho, que foi rink e foi frontão.

O primeiro ponto que chama a atenção é a forma como o espectador é referido, sendo apenas uma vez sob essa denominação. Em diversos pontos do texto, o público é chamado de "viajante", "excursionista" e "passageiro". A própria sessão é também chamada de “viagem" e "excursão". A atração não está apenas nas vistas da Palestina, mas, talvez principalmente, na rara possibilidade que o espectador teria de sentir-se como se fosse um turista. Em segundo lugar, é preciso comentar a ênfase que o texto dá para a ilusão que o espectador tem, a de estar em outro lugar que não o salão da rua Onze de Junho. E isso só é possível porque o aparelho lança mão de diversas estratégias para dar a sensação de imersão no ambiente da viagem. Tudo começa na compra da passagem, passando pela sala de espera, a "chegada" do vagão, o funcionário que faz o papel de guarda-trem, os efeitos sonoros e a movimentação do carro. Não se pode deixar de comentar também a referência à passagem que a viagem ilusória faz por um túnel, o que fazia parte do imaginário dos espectadores em relação à estrada de ferro.

Depois são listadas as figuras presentes na inauguração, dentre as quais estavam deputados, militares, famílias importantes e representantes da imprensa. Além deles, Jean Danêres que, segundo o texto, foi quem montou a atração em Buenos Aires, veio da Argentina especialmente para participar da instalação do aparelho. À respeito da origem do divertimento, a notícia nos diz que, antes de vir para o Brasil, o Ferro Carril Asiático “obteve [sucesso] na exposição de Paris em 1900, depois em Napoles e ultimamente na capital cisplatina". Mais adiante temos a confirmação de nossa suspeita, a atração não fazia uso de projeções cinematográficas: "A tela em que foi trabalhado com requintada arte o panorama da Terra Santa tem 30 metros de comprimento por 8 de largura e é movida em 9 cylindros." Trata-se de um panorama pintado em uma longa tela, que se desenrola nas janelas do vagão cenográfico. Por conta dessas informações, podemos imaginar que a atração tenha sido parecida com o panorama transiberiano que passou pela Exposição Universal de Paris. ${ }^{152}$ Outro dado interessante aparece no final do texto: "Ao revmo. sr. padre Francisco Martins Dias, vigario de Araras, a cujos esforços se deve a

${ }^{152}$ TOULET, Emmanuelle. Cinema at the Universal Exposition, Paris, 1900. In: Persistence of Vision, no. 9, 1991, p. 18. 
installação nesta capital do engenhoso estabelecimento, agradecemos as gentilezas de que cumulou nosso representante." A participação de um padre na instalação do Ferro Carril Asiático parece servir, aqui, como legitimação do caráter instrutivo da atração, aspecto que, como veremos adiante, será usado outras vezes como estratégia de divulgação. $\mathrm{O}$ destino da viagem é o principal motivo para a atração ser considerada tão instrutiva. As já citadas conferências ilustradas por projeções de lanterna mágica eram muitas vezes realizadas em igrejas e, nesses casos, o caráter educativo podia aliar-se à pregação. E no caso do Ferro Carril esse aspecto era de fato aproveitado, como podemos ler no Correio Paulistano, alguns dias depois:

Com affluencia de passageiros cada vez mais crescente, vai este novo genero de divertimento se impondo à admiração do publico desta capital. Hontem, às 5 horas da tarde partiu um trem conduzindo um grupo de alumnos do Gymnasio Diocesano e corpo docente daquelle estabelecimento. ${ }^{153}$

Como pode-se ver na figura 44, reprodução de um anúncio, os preços da viagem são diferenciados entre primeira e segunda classes, adultos e crianças.

${ }^{153}$ FERRO Carril Asiatico. Correio Paulistano, 08/04/1906, p. 4. 


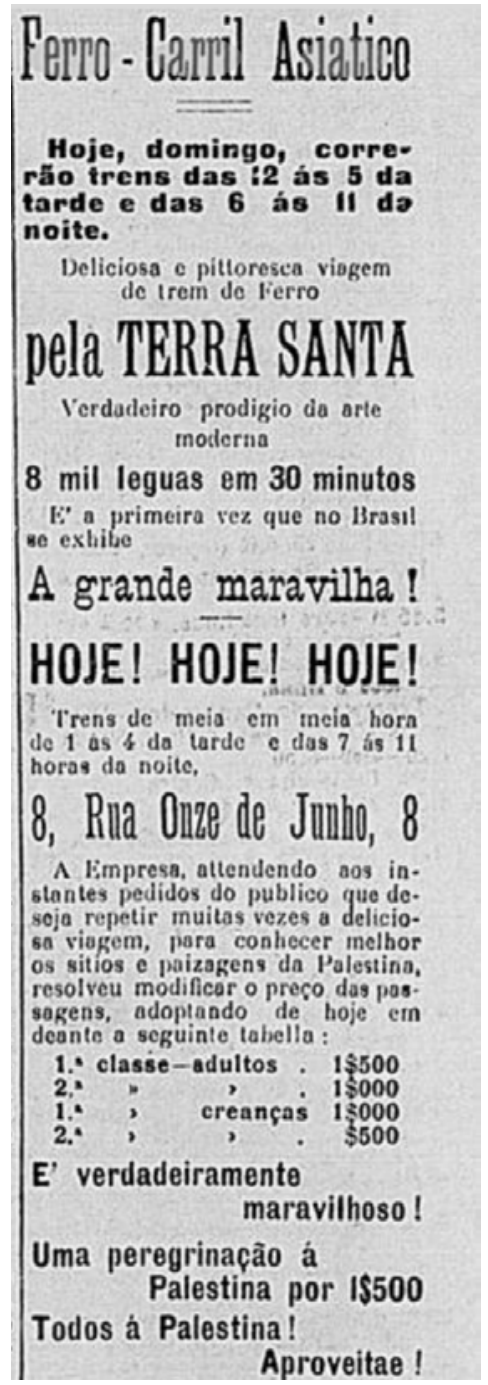

Figura 44 - Correio Paulistano, São Paulo, 06/05/1906, sem página.

Não sabemos qual era o preço nos primeiros dias da temporada, mas partir de 24 de abril, 20 dias depois de sua estreia, o Ferro Carril diminui os preços:

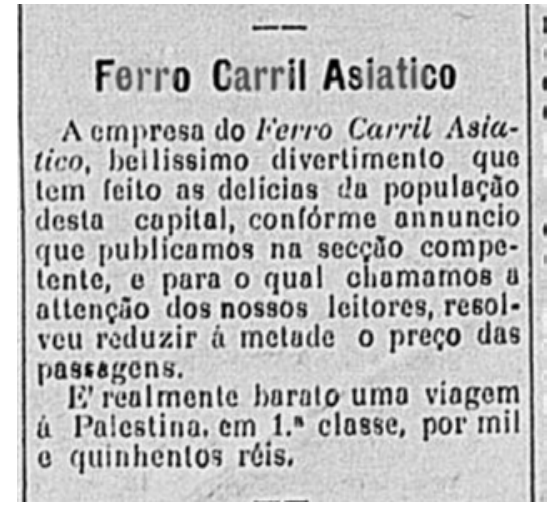

Figura 45 - Correio Paulistano, São Paulo, 24/04/1906, p. 3. 
Quando a atração foi para o Rio de Janeiro, também passou pela diminuição do preço do ingresso. $\mathrm{O}$ tom de ambas as publicações é bastante diferente, como se pode ver neste comentário, publicado em outubro de 1906:

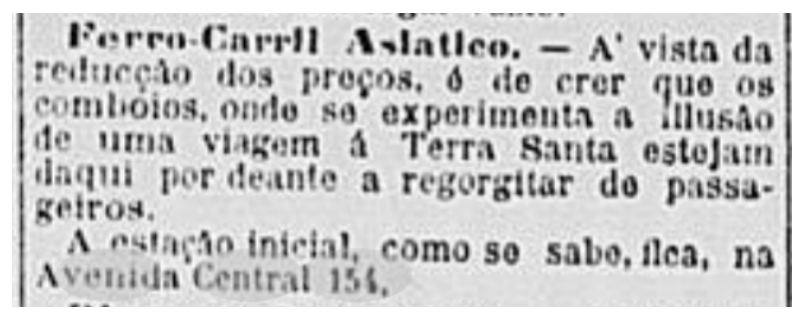

Figura 46 - Correio da manhã, Rio de Janeiro, 24-10-1906, sem página.

A comparação dos dois documentos nos faz pensar sobre as diferenças entre o que era considerado sofisticado em cada uma das cidades. Em São Paulo, o jornal demonstra ser uma oportunidade única ter o privilégio de tomar parte em uma "viagem" como essa por apenas mil e quinhentos reis. Já no caso da então capital federal, a redução de preços é a causa para os vagões "regorgitarem" de pessoas. O dado interessante, aqui, é que o preço no Rio depois da redução é o mesmo que os paulistas pagaram. Sabemos que São Paulo era mais provinciana e considerada culturalmente inferior. ${ }^{154}$ Talvez o jornalista carioca pensasse que a popularização em consequência da diminuição de preço seria responsável por rebaixar o nível social dos frequentadores. Talvez os preços mais baixos não combinassem com o status da avenida na qual foi instalado. Passemos então à temporada que a atração teve naquela cidade.

No Rio de Janeiro, como dissemos, o Ferro Carril Asiático foi instalado no Pavilhão Internacional, empresariado por Pascoal Segreto, de 7 de julho de 1906 até 6 de abril de 1908. Segreto foi "responsável pela criação e/ou administração de parques de diversões, choperias, casas de variedades e estabelecimentos de atrações musicais." Depois, ele ainda vai ser responsável por diversos outros espaços de entretenimento em várias cidades, como a área de diversões da Exposição Nacional de 1908 no Rio de Janeiro, que será discutida no terceiro capítulo.

O Pavilhão ficava no número 154 da Avenida Central (atual Avenida Rio Branco), o "símbolo maior das reformas urbanas de Pereira Passos, [que] desde cedo (...) atraiu o

\footnotetext{
${ }^{154}$ SOUZA, José Inácio de Melo. Imagens do passado: São Paulo e Rio de Janeiro nos primórdios do cinema. São Paulo: Editora Senac, 2004, p. 44.

${ }^{155}$ MORAES, Julio Lucchesi. Sociedades culturais, sociedades anônimas: distinção e massificação na economia da cultura brasileira (Rio de Janeiro e São Paulo, 1890 - 1922). São Paulo, Programa de PósGraduação em História Econômica da Universidade de São Paulo, 2014. Tese (Doutorado em História Econômica), p. 233.
} 
interesse dos exibidores, sequiosos de conquistar o abastado público frequentador da região". ${ }^{156}$ A prefeitura de Pereira Passos (1902-1906), como se sabe, foi responsável pelo alargamento das ruas da então capital federal. Foi ele que criou o marco que foi a Avenida Central, essencial no processo de estabelecimento das primeiras salas fixas de cinema. Melo Souza, citando um dos memorialistas cujas lembranças utiliza em seu livro, mostra a importância desta avenida entre 1908 e 1910, quando ela passou a ser um local de encontro obrigatório da elite política e social do Rio. ${ }^{157} \mathrm{O}$ local onde foi instalado o Ferro Carril estava, ainda por cima, no lado nobre da avenida, como podemos deduzir pelo seu número, 154. O lado ímpar, por receber mais sol, era menos valorizado e não tão bem frequentado. ${ }^{158}$

O primeiro programa exibido lá foi o mesmo que os paulistas viram, a "Viagem à Palestina" ou "Viagem à Terra Santa". Sua temporada parece ter durado de 7 de julho de 1906 até 26 de janeiro de 1907. Cerca de três meses depois da estreia, dois jornais cariocas ${ }^{159}$ publicaram um texto longo e interessantíssimo sobre a atração. No título lêemse os seguintes dizeres: "Maravilhoso espetaculo / DESLUMBRANTE PANORAMA / VIAGEM Á TERRA SANTA PELO FERRO CARRIL ASIATICO / A mais attrahente e instructiva diversão nunca vista no Brasil”. Destas primeiras linhas, devemos destacar o uso das palavras “viagem" e "instructiva diversão", pois remetem a alguns dos elementos mais importantes comumente ligados aos simuladores de viagem nos Estados Unidos e Europa. O uso da palavra "viagem", logo no título da matéria, remete à sensação que os tours buscavam causar nos espectadores: a de sentir-se como se estivesse em uma viagem real. A referência à atração como "instructiva diversão" nos faz lembrar das conferências de viagem, que buscavam a instrução dos espectadores e "encarnavam os princípios da cultura americana refinada". ${ }^{160} \mathrm{O}$ texto começa então com uma longa justificativa do sucesso do simulador nos "paizes cultos da Europa", afirmando que essa "não [era] uma

\footnotetext{
${ }^{156}$ MORAES, Julio Lucchesi. Sociedades culturais, sociedades anônimas: distinção e massificação na economia da cultura brasileira (Rio de Janeiro e São Paulo, 1890 - 1922). São Paulo, Programa de PósGraduação em História Econômica da Universidade de São Paulo, 2014. Tese (Doutorado em História Econômica, p. 272.

157 SOUZA, José Inácio de Melo. Imagens do passado: São Paulo e Rio de Janeiro nos primórdios do cinema. São Paulo: Editora Senac, 2004, p. 47.

${ }^{158}$ MORAES, Julio Lucchesi. Op. cit., p. 269.

${ }^{159}$ MARAVILHOSO espetaculo. O Paiz, Rio de Janeiro, 30/09/1906, p. 5; Idem. Correio da Manhã, Rio de Janeiro, 03/10/1906, p. 4

${ }^{160}$ MUSSER, Charles. The emergence of cinema: the american screen to 1907. Berkeley / Los Angeles: University of California Press, 1990, 1990, p. 221.
} 
diversão vulgar". Mais à frente, lemos que o panorama recebeu "a mais justa e lisongeira apreciação do publico intelligente e civilizado".

Toda a primeira metade do artigo foca na exaltação dos efeitos causados no público. Segundo a descrição, a novidade, que seria um dos mais belos espetáculos do mundo, causa deslumbre à curiosidade dos espectadores ávidos de conhecer as maravilhas do mundo. Faz quem experimenta os efeitos do encantador divertimento sentir uma grande emoção, causa a mais agradável impressão e provoca um verdadeiro êxtase ao observador. E o mais importante é que o aparelho causa a "completa illusão de se estar viajando em trem de ferro, a grande distancia e velocidade", o que, por aparecer aqui como um aspecto positivo do simulador, mostra a eficácia que este teve em reproduzir a sensação de tomar parte no que havia de mais moderno na época.

É apenas neste ponto, na metade do texto, que o conteúdo das imagens projetadas no interior do Ferro Carril Asiático são finalmente explicitadas: os lugares mais célebres da Terra Santa, o que "symboliza uma parte interessante e instructiva da vida do Redemptor da humanidade, cujos feitos estão proclamados na escriptura sagrada, o que decerto deve interessar ao povo crente da religião catholica".

Ao final, a sensação de ter feito uma viagem real quando na verdade o espectador tinha assistido ao panorama apresentado na sala do Ferro Carril Asiático é reiterada pelas seguintes palavras:

\footnotetext{
Tão agradavel impressão causou em nosso espirito a viagem que no FerroCarril Asiatico fizemos à Terra Santa, onde se descortina o immenso, bello e curioso panorama da Palestina, que não temos palavras enconmiasticas que possam traduzir a nossa grande e sincera admiração por tudo quanto se refere a esse esforço, compreendido na installação dessa grandiosa novidade, que constitue um mecanismo original e engenhosissimo e que reputamos a melhor e a mais util diversão da actualidade.
}

Fica claro o desejo de afirmação do simulador através de sua elevação. A atração, além de ser apreciada na Europa, é descrita como culta, civilizada e atualizada. É aproximando a experiência ao que há de mais moderno e invulgar, que o jornal a defende como digna da atenção da elite carioca.

A revista $O$ Malho publicou alguns anúncios do Ferro Carril, dos quais é possível extrair algumas questões. A primeira delas diz respeito àquela "pontualidade britânica", que vimos no texto que descrevia a atração em São Paulo. É a longa lista dos horários precisos de "saída" dos "trens", que vemos no recorte reproduzido abaixo. A aniquilação do espaço e do tempo que a estrada de ferro instaurou ganha aqui um caráter extremo: é 
possível percorrer oito mil léguas em apenas 30 minutos. E, a cada 35, sai um novo comboio rumo ao Oriente.

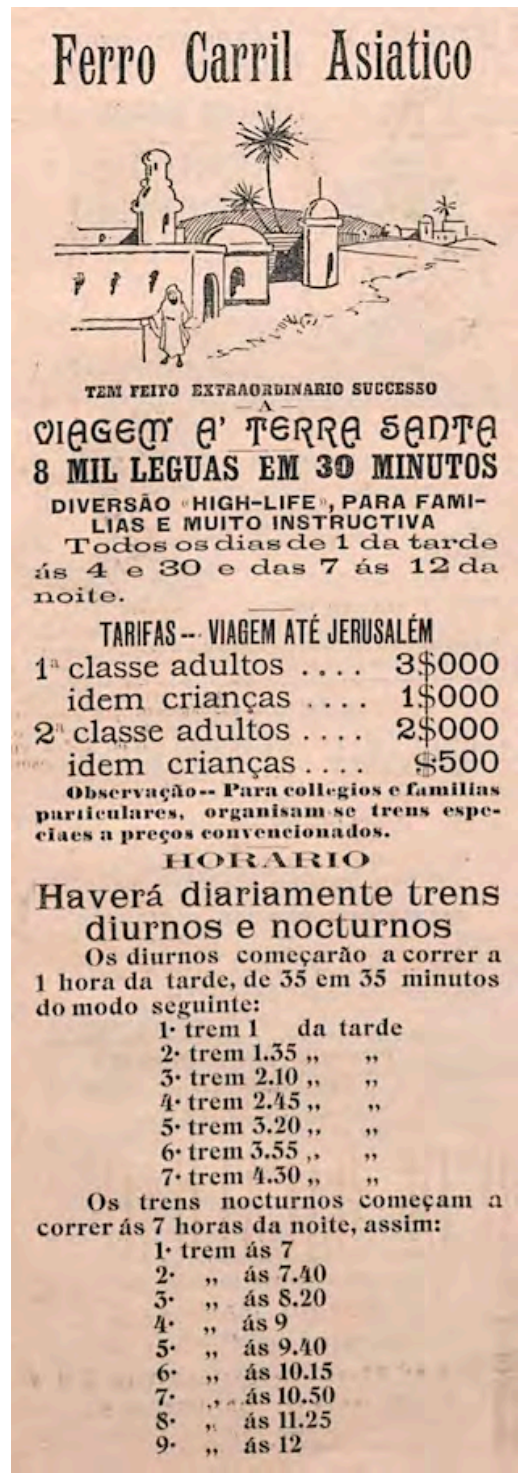

Figura 47 - O Malho, Rio de Janeiro, 22-09-1906, ano 5, número 210, p. 6.

Outro aspecto interessante do anúncio está no desenho, que enfatiza o caráter exótico das paisagens exibidas. Mas havia outros, como é demonstrado abaixo, cuja ilustração se referia próprio veículo, o trem. 


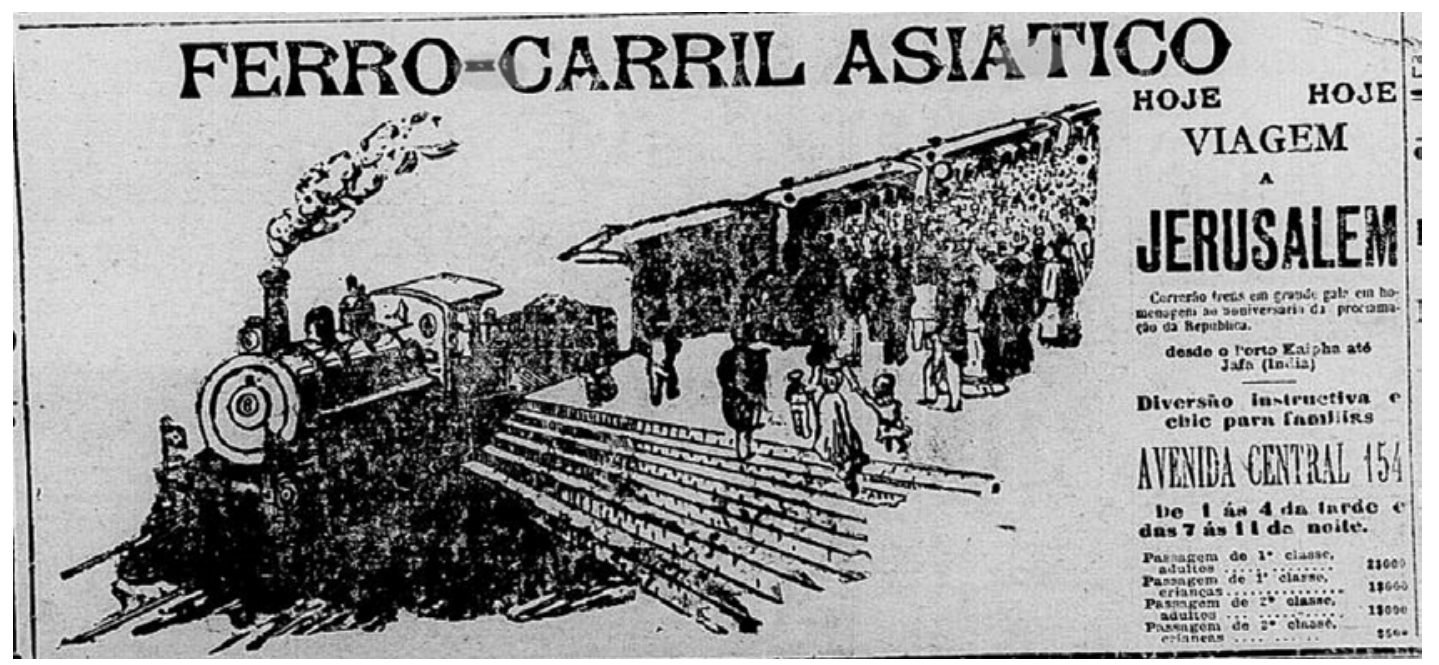

Figura 48 - Jornal do Brasil, Rio de Janeiro, 15-11-1907, p. 18.

A partir de 04 de fevereiro até 26 de setembro de 1907, os anúncios referentes ao Ferro Carril Asiático passam a promover uma outra atração do mesmo tipo. Agora os visitantes do Pavilhão Internacional teriam a possibilidade de fazer uma "Viagem à volta do mundo":

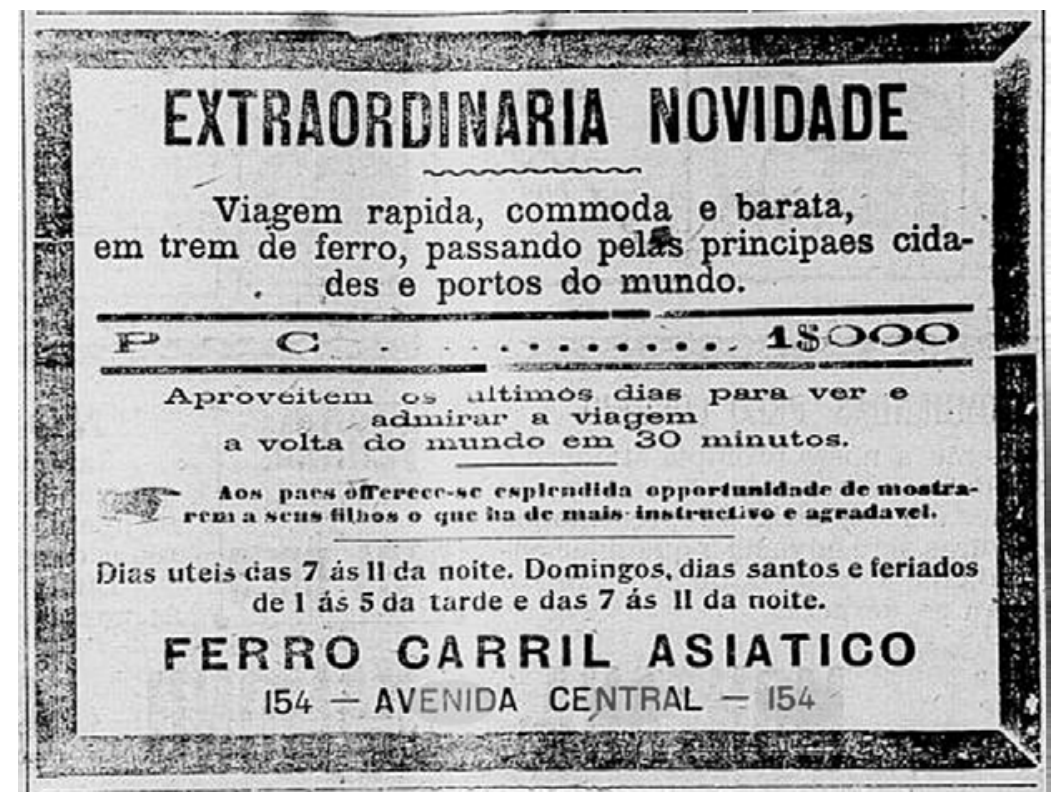

Figura 49 - Jornal do Brasil, Rio de Janeiro, 21-07-1907, sem página.

E novamente encontramos referência ao interesse que a atração pode ter para as crianças e, como se pode ver, houve mais uma redução de preço. A viagem passava pelos seguintes lugares: Argentina, Chile, Califórnia, Japão, China, Índia, Egito, Áustria, Grécia, Itália, 
Espanha, Argel, Nova York. ${ }^{161}$ Mais uma vez, a ideia de tornar a viagem algo mais acessível aparece: "Ferro Carril Asiático - Os senhores querem viajar, conhecer mundos, passear capitaes, e gastar pouco dinheiro? Nada mais facil. Vão alli à estação do Ferro Carril Asiatico, na Avenida Central, tomem uma passagem de $1^{\text {a }}$ classe, por dous mil reis (!) e aí está...". ${ }^{62}$

A partir de 14 de outubro de 1907 passamos a encontrar anúncios que não mais citam o nome do Ferro Carril Asiático, mas divulgam uma outra viagem mundial bastante similar no mesmo Pavilhão da Avenida Central. É a Estrada de Ferro Mundial, que realizou as chamadas "Viagens a volta do mundo em 25 minutos". Até o dia 6 de abril de 1908 é possível encontrar referências a essa atração, que consistia em um panorama que mostrava as vistas de uma viagem de Buenos Aires até o Japão. Apesar de algumas diferenças (como o título e a duração), é possível que fosse a exibição dos mesmos paineis da atração anterior, apenas alterada em alguns aspectos para parecer uma novidade e, assim, chamar a atenção do público.

Sobre o interior do simulador, um anúncio dizia: "a empreza chama a attenção para o conforto e commodidade com que se acha preparada esta viagem mundial - Carros ventilados, tornado-se por isso um adoravel passa-tempo". ${ }^{163}$ A ênfase na ventilação nos remete aos esforços que empresários e parte da imprensa estavam empreendendo na época no sentido de melhorar a reputação desses espaços de divertimento, elevando seu status aos olhos da elite. Apesar disso, a atração também sofreu redução nos preços em fevereiro de 1908.

Apesar de, como percebemos, não ter exibido filmes em seu interior, os diferentes panoramas instalados sob o título de Ferro Carril Asiático (ou o que o sucedeu no Pavilhão Internacional), nos ajudam a compreender o contexto de exibição de imagens de viagem no começo do século XX no Brasil. Vimos que essas atrações foram instaladas em lugares nobres de ambas as cidades e estiveram ligadas à instrução, diversão e religião. Seus preços abaixaram ao longo do tempo e parecem ter tido algum sucesso. Era, enfim, uma diversão familiar, com lugares para adultos e crianças, que buscava reproduzir alguns dos aspectos ligados aos transportes modernos: velocidade, pontualidade e novidade.

\footnotetext{
161 Jornal do Brasil, Rio de Janeiro, 06/06/1907, p.8.

${ }^{162}$ Gazeta de Notícias, Rio de Janeiro, 18/03/1907, p. 2. Agradecemos à pesquisadora Danielle Crepaldi Carvalho por ter chamado nossa atenção para este anúncio.

${ }^{163}$ Correio da manhã, Rio de Janeiro, 21/11/1907, p. 8.
} 


\section{Viagem excitante}

O simulador Auto-Tours teve três temporadas diferentes, passando pelas cidades de Rio de Janeiro, São Paulo e Porto Alegre, de março de 1907 a maio de 1908. Aparentemente, como veremos adiante, a atração, então sob o título de CinemaAutomóvel, retornou ao Rio, de julho até agosto de 1908. A primeira instalação no Rio de Janeiro permaneceu no número 27 da Praça Tiradentes pelo menos de 20 de março de 1907 até o dia 31 do mesmo mês, exibindo vistas cinematográficas das cidades americanas Nova York, São Francisco e Washington, percorridas em automóvel.

Logicamente, não havia diferença entre $1^{\mathrm{a}}$ e $2^{\mathrm{a}}$ classes, como era o caso dos trens do Ferro Carril, já que se tratava de um automóvel (figura 50).

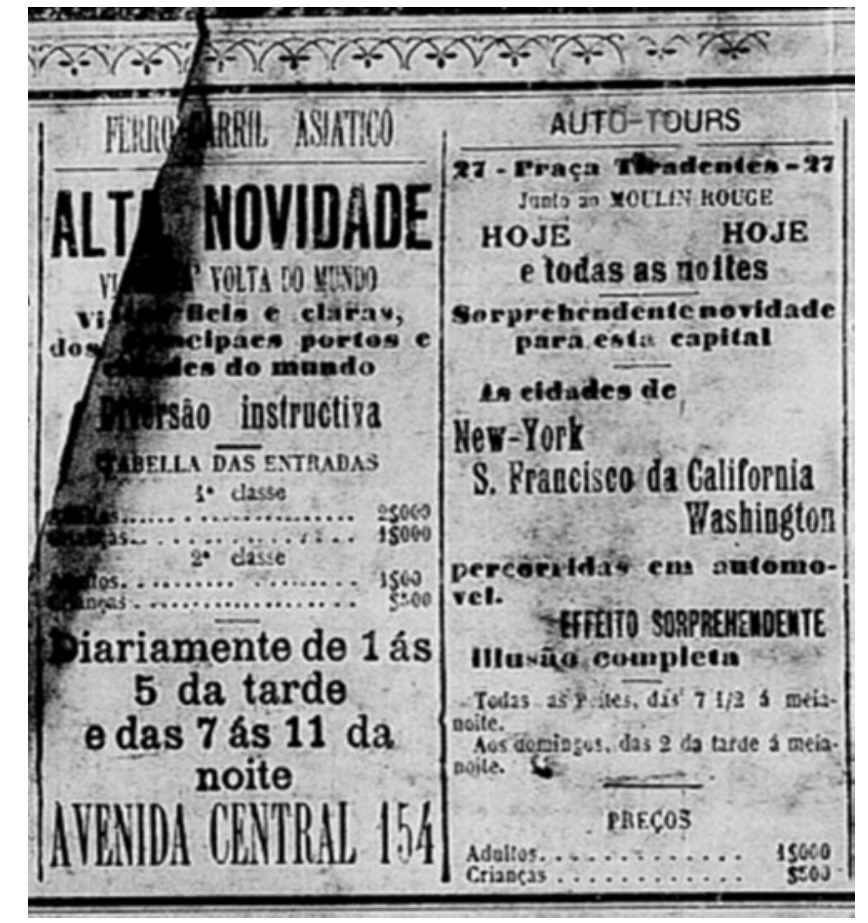

Figura 50 - Jornal do Brasil, Rio de Janeiro, 31-03-1907, p. 16.

No interessante recorte acima, podemos ver os anúncios da "Viagem à volta do mundo" daquele panorama e do passeio de automóvel do Auto-Tours, lado a lado. Mais do que as diferenças (de preço e horário de exibição), o recorte nos faz pensar sobre as semelhanças entre os aparelhos. Os anúncios mostram que, ao contrário do que se pode pensar, os simuladores de viagem não tiveram uma evolução linear, o cinematográfico substituindo o panorâmico. As duas atrações, na verdade, competiam pelo mesmo público, interessado nas novidades estrangeiras e desejoso por tomar contato com vistas de lugares distantes. 
Não ficam nem mesmo explícitas que as vistas eram cinematográficas, no caso do AutoTours. Até mesmo as palavras utilizadas para descrever a atração, como "ilusão completa", também eram, como vimos, usadas para fazer referência ao Ferro Carril. Por outro lado, não podemos deixar de comentar as diferenças: enquanto o Ferro Carril era mais caro e funcionava durante a tarde e a noite, sendo uma atração mais familiar, o AutoTours, apesar de também ter ingressos para crianças, suas exibições, com exceção do domingo, eram apenas noturnas e iam até mais tarde.

Outra semelhança está na busca por legitimação no sucesso que as atrações teriam feito no estrangeiro. Mas, como podemos perceber por essa nota, publicada por ocasião da estreia do Auto-Tours no Rio de Janeiro, enquanto o panorama ferroviário buscava amparo no sucesso europeu, a atração cinematográfica buscava-o na reputação americana:

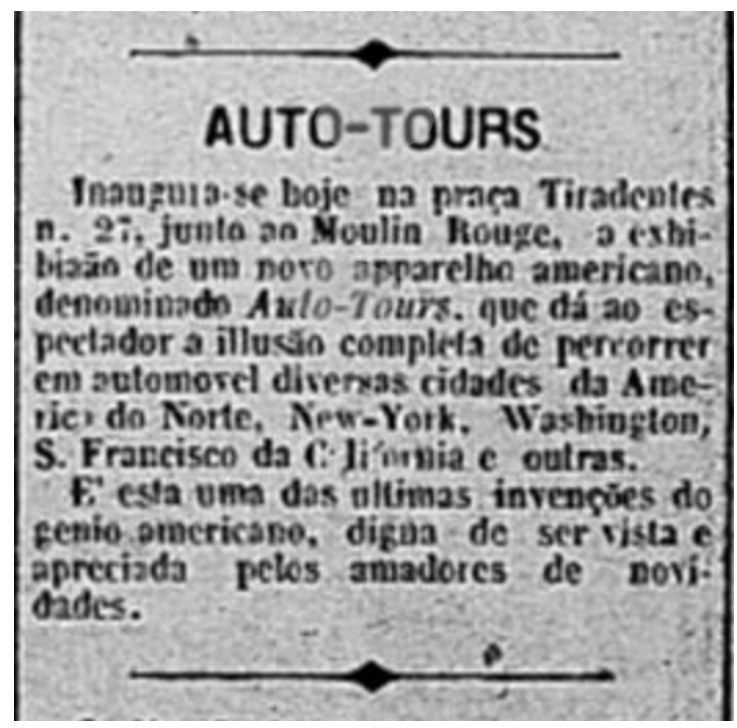

Figura 51 - Jornal do Brasil, Rio de Janeiro, 20-03-1907, p. 2.

É importante chamar a atenção para esse esforço por legitimação, dado que o automóvel é, e era na época, muito associado aos Estados Unidos. Foi em 1908 que a Ford lançou o famoso Modelo T, que participou da popularização desse meio de transporte. A imprensa brasileira, portanto, relacionou o Auto-Tours a uma nação que procurava se associar ao moderno via inovações tecnológicas - uma delas o carro e outra, o cinema.

A atração foi depois para São Paulo, instalando-se no Salão Progredior, que ficava no número 38 da Rua Quinze de Novembro, de 19 de julho até cerca de 18 de agosto de 1907. Os preços foram os mesmos que o espetáculo praticou no Rio. E não é à toa que fossem mais baratos que o Ferro Carril. Os locais onde foi instalado o Auto-Tours em 
ambas as cidades não era tão sofisticados quanto as localidades que aquele panorama ocupou.

Na nota reproduzida abaixo, mais uma vez as duas atrações são aproximadas:

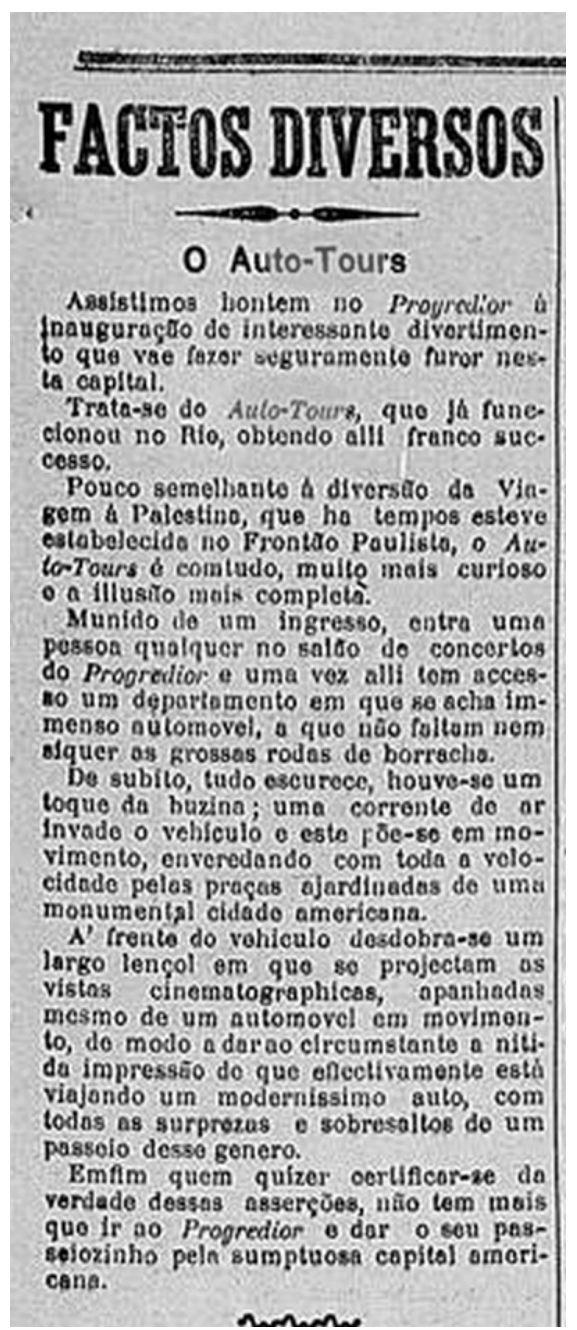

Figura 52 - Correio Paulistano, São Paulo, 21/07/1907, p. 5.

E temos, aqui, um maior detalhamento do aparelho, finalmente aparecendo a referência ao fato das vistas serem cinematográficas. Tomamos conhecimento também de outros aspectos da simulação: há efeitos sonoros e são lançados jatos de vento contra os espectadores. É também a partir da descrição acima que podemos imaginar o tipo de imagem exibida. Eram, muito provavelmente, filmes do tipo viagem fantasma, dado que são descritas como "apanhadas mesmo de um automovel em movimento". A ênfase para as "surprezas e sobresaltos" do passeio sugere que uma das principais atrações do aparelho estava justamente na possibilidade do espectador tomar contato com a excitação sensorial do tráfego moderno. Era comum que esses filmes, tomados de veículos em 
movimento como carros ou trens, usassem determinados tipos de vistas, como a passagem por túneis ou pontes, que enfatizavam o fato de que o espectador podia compartilhar seu ponto de vista com o do veículo. Outro anúncio nos remete ao uso do túnel nas telas pintadas do Ferro Carril Asiático. Nos Auto-Tours parece ocorrer o mesmo, mas dessa vez com a vista tomada da famosa ponte de Nova York:

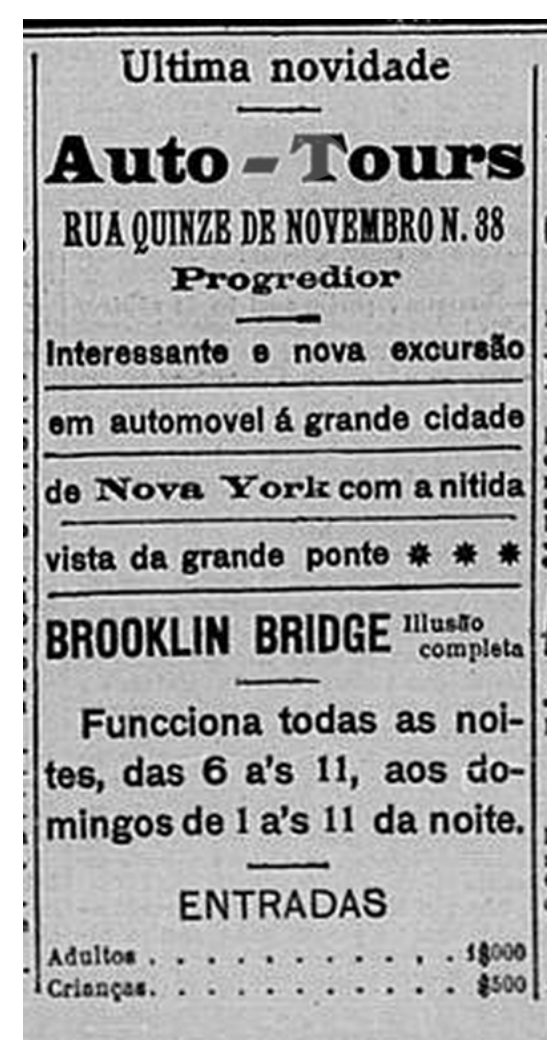

Figura 53 - Correio Paulistano, São Paulo, 06/08/1907, p. 5.

Quando passou por Porto Alegre, o Auto-Tours foi instalado no Hotel Brazil, que ficava no número 327 da importante Rua dos Andradas, de 18 de abril até cerca de 29 de maio de 1908. Funcionava das 6 e meia da tarde até as 11 da noite, custando, assim como nas outras cidades, $1 \$ 000$ rs para adultos e $\$ 500$ rs para crianças, ${ }^{164}$ o que foram considerados "preços módicos". ${ }^{165}$ A atração consistia no mesmo passeio de automóvel pelos Estados Unidos, no qual "o espectador assiste ao panorama de cidades e outras vistas de sensação". 166

Alguns aspectos do simulador podem ser retirados do recorte abaixo:

\footnotetext{
${ }^{164}$ TRUSZ, Alice. Entre lanternas mágicas e cinematógrafos: as origens do espetáculo cinematográfico em Porto Alegre (1861-1908). São Paulo: Editora Terceiro Nome, 2010, p. 222.

${ }^{165}$ A Federação, Porto Alegre, 20/04/1908, p. 2.

${ }^{166}$ Correio do Povo, Porto Alegre, 19/04/1908, p. 2 apud TRUSZ, Alice. Op. cit., p. 222.
} 


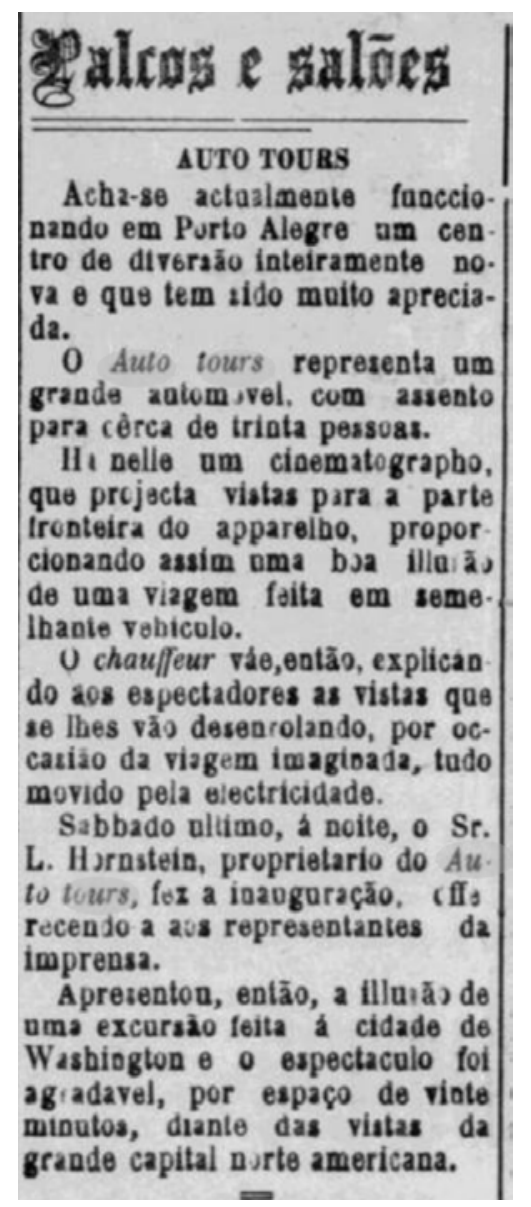

Figura 54 - A opinião pública, Porto Alegre, 24/04/1908, p. 2.

Em primeiro lugar, a pequena quantidade de pessoas que o carro comportava por vez, o que nos ajuda a ter ideia do tamanho da sala de projeção: muito maior que um carro para 4 pessoas, mas certamente menor que muitos salões fixos que instalar-se-ão nesta e em outras cidades nesse período. Se fosse grande demais, certamente a ilusão perderia sua força. Outro elemento interessante é que o próprio exibidor parece ter feito o papel de condutor da viagem, seguindo a tradição dos conferencistas de viagens, comuns nas projeções da lanterna mágica. Fica clara, nesse texto, a novidade do aparelho, que não teve precedentes na cidade. Segundo Trusz, a imprensa local, por conta do ineditismo da atração, teve dificuldades em definir o simulador: "Enquanto que o Jornal do Comércio o referiu simplesmente como "cinematógrafo" (23/04) e o Independente como "aparelho" (03/05), o Correio do Povo acabou empregando expressões como "aparelho automóvel" (25/04), "automóvel cinematográfico" (26/04) e mesmo "aparelho panorâmico" $(02 / 05),{ }^{167}$

\footnotetext{
${ }^{167}$ TRUSZ, Alice. Entre lanternas mágicas e cinematógrafos: as origens do espetáculo cinematográfico em Porto Alegre (1861-1908). São Paulo: Editora Terceiro Nome, 2010, 225.
} 
Depois de exibir filmes de Washington, o Auto-Tours passou a levar seus espectadores para uma viagem imaginária a São Francisco, programa que permaneceu de 4 a 17 de maio de $1908 .{ }^{168}$ É deste programa que acreditamos ter participado o filme Uma viagem pela Market Street antes do incêndio (A trip down Market Street before the fire, Irmãos Miles, 1906), que será alvo de nossa análise. A partir de um anúncio publicado no Correio do Povo, Trusz conclui que,

desta vez, o espectador não só teria a oportunidade de conhecer uma outra cidade norte-americana, mas uma cidade que não mais existia, que já era passado, pois havia sido destruída por um desastre natural ${ }^{169}$ (...). Além do deslocamento espacial imaginário, se faria também uma verdadeira viagem no tempo e graças ao registro cinematográfico, neste caso duplamente valorizado do ponto de vista documental. Afinal, o filme em questão já não era mais uma simples vista turística (...), mas também um documento histórico que fazia referência a uma grande catástrofe e suas consequências sobre a vida de uma grande cidade, tema muito apreciado na época. ${ }^{170}$

Sobre o filme e as questões levantadas por Trusz, trataremos mais adiante. A partir do dia 18 de maio, ao que parece, os filmes exibidos passaram a ser vistas de Nova York, incluindo a Ponte do Brooklyn, como havia sido nas outras cidades.

Por fim, sob o nome de Cinema-Automóvel, um aparelho aparentemente muito similar aos Auto-Tours também passou pelo Pavilhão Internacional do Rio de Janeiro, de 21 de julho de 1908 até pelo menos 08 de agosto do mesmo ano, exibindo filmes de Washington e outras cidades da América e Europa percorridas em automóvel. As descrições dessa atração e as datas em que seus anúncios aparecem nos jornais cariocas apontam para a possibilidade de ter sido o mesmo Auto-Tours, anunciado como novidade. Em alguns anúncios, inclusive, aparece o nome dessa atração entre parêntesis (figura 55).

\footnotetext{
${ }^{168}$ TRUSZ, Alice. Entre lanternas mágicas e cinematógrafos: as origens do espetáculo cinematográfico em Porto Alegre (1861-1908). São Paulo: Editora Terceiro Nome, 2010, pp. 228-229.

${ }^{169}$ A cidade de São Francisco foi assolada, em 18 de abril de 1906, por um terremoto e diversos incêndios. Foram mais de 3.000 mortos e pelo menos 200.000 desabrigados. O filme A trip down Market Street before the fire (Irmãos Miles, 1906) foi filmado apenas 4 dias antes do desastre.

170 TRUSZ, Alice. Op. cit., p. 228.
} 


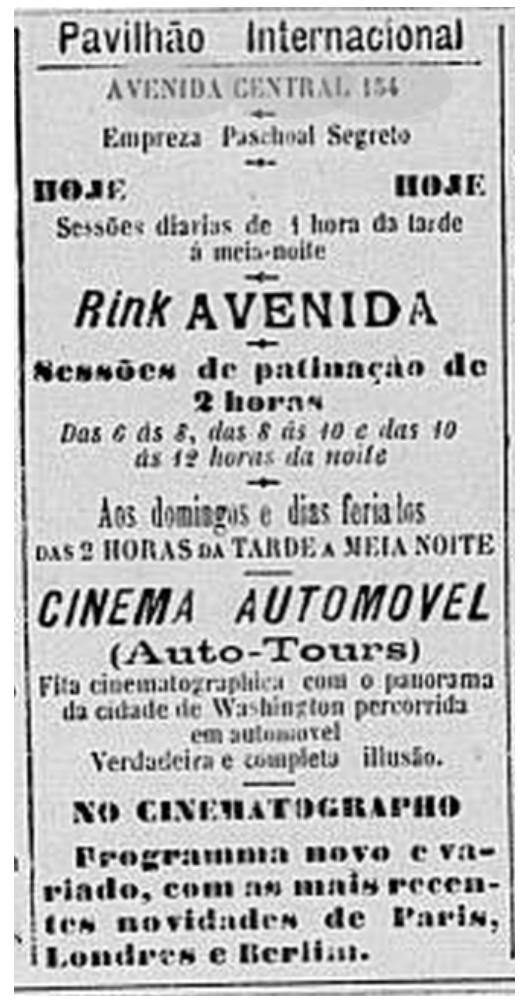

Figura 55 - Jornal do Brasil, Rio de Janeiro, 08/08/1908, p. 15.

Além disso, a referência às vistas de Washington também sugere que seja o mesmo programa do Auto-Tours. Outros anúncios dizem que as viagens simuladas têm como “destino" as principais cidades da América e da Europa, o que nos faz imaginar que outros filmes possam ter sido incluídos no programa original, para agradar àqueles que já tinham visto a atração em sua primeira temporada na cidade. Um exemplo é o recorte reproduzido a seguir: 


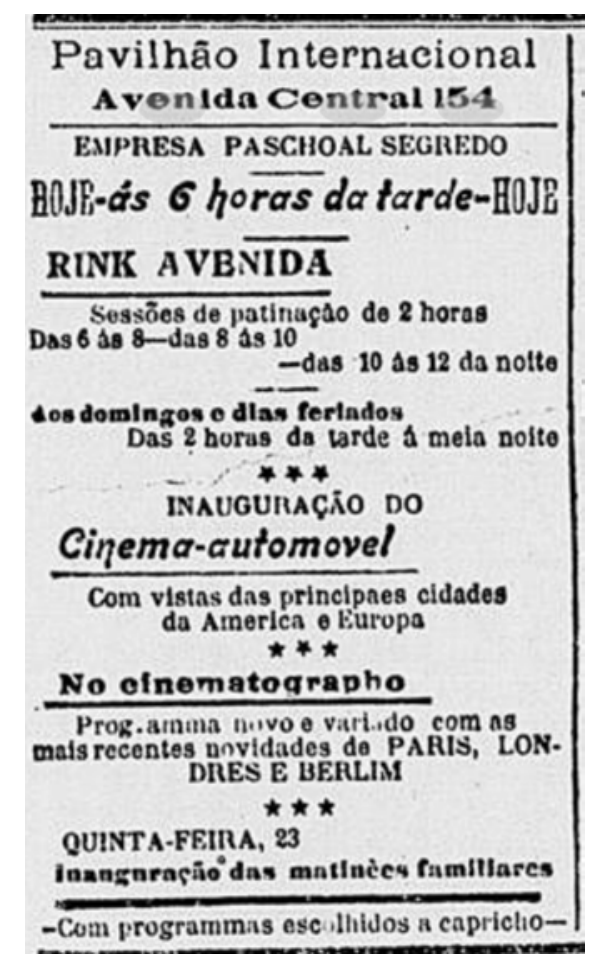

Figura 56 - Correio da manhã, Rio de Janeiro, 21/07/1908, p. 8.

Segundo Alice Gonzaga, o Cinema-Automóvel teria sido patenteado como Auto-Brasil pelo empresário Emilio Guimarães. ${ }^{171}$ Mas seu pedido de patente, analisado por nós, não menciona a pretensão de instalar o aparelho no Pavilhão Internacional tampouco tem como objetivo exibir vistas americanas ou europeias. Pelo contrário, o texto diz:

\begin{abstract}
A invenção tem por fim a propaganda geral dos melhoramentos e embelesamento d'esta Capital e mais estados do Brazil pela aplicação de fitas cinematographicas tomadas n'um automovel em passeio pelas ruas Commerciaes e Avenidas, e da mesma forma por meio de projeções e auxilio do "Auto-Brazil" obtendo a realidade e illusão completa do natural. ${ }^{172}$
\end{abstract}

A patente foi registrada no dia 18 de maio de 1907, dois meses depois da primeira instalação do Auto-Tours e cerca de um ano antes da estreia do Cinema-Automóvel, o que sugere que o aparelho de Guimarães possa ter sido o Cinema-Automóvel ou outro (que permanece desconhecido), ou ainda que não tenha sido concretizado.

O Auto-Brasil é descrito, no pedido de patente, como um aparelho que dará a ilusão completa de movimento a partir da união entre a projeção de filmes e o movimento

${ }^{171}$ Cf. GONZAGA, Alice. Palácios e poeiras: 100 anos de cinema no Rio de Janeiro. Rio de Janeiro: Record/Funarte, 1996, p. 277.

172 CINEMATECA BRASILEIRA (Org.). Coleção de memoriais descritivos acompanhando pedidos de privilégios e patentes de invenções relacionadas com o meio cinematográfico. Fornecida por José Inácio de Melo Souza a partir de pesquisa no Arquivo Nacional. Pasta D1329f, p. 1. 
do carro, incluindo a sensação de curvas e a trepidação do motor. Sobre os filmes, a patente diz que o aparelho projetaria "a fita Cinematographica Panoramica tomada em Automovel, fita esta que em exibição parece correr para cima do espectador, mostrando assim em toda sua extensão os pontos de passagem do automovel operado" ${ }^{\text {173 }}$. Parecenos acertado sugerir que a intenção fosse a de projetar filmes do tipo phantom ride.

$\mathrm{Na}$ sala onde seria instalado, haveria telas pintadas "sem fim", "telas estas que terão um movimento continuo em sentido inverso a carreira do automóvel"174. Este procedimento dialoga com a tradição dos dioramas e panoramas, sugerindo que o AutoBrasil fosse um aparelho híbrido, que unia imagens em movimento cinematográficas e imagens em movimento pintadas à mão.

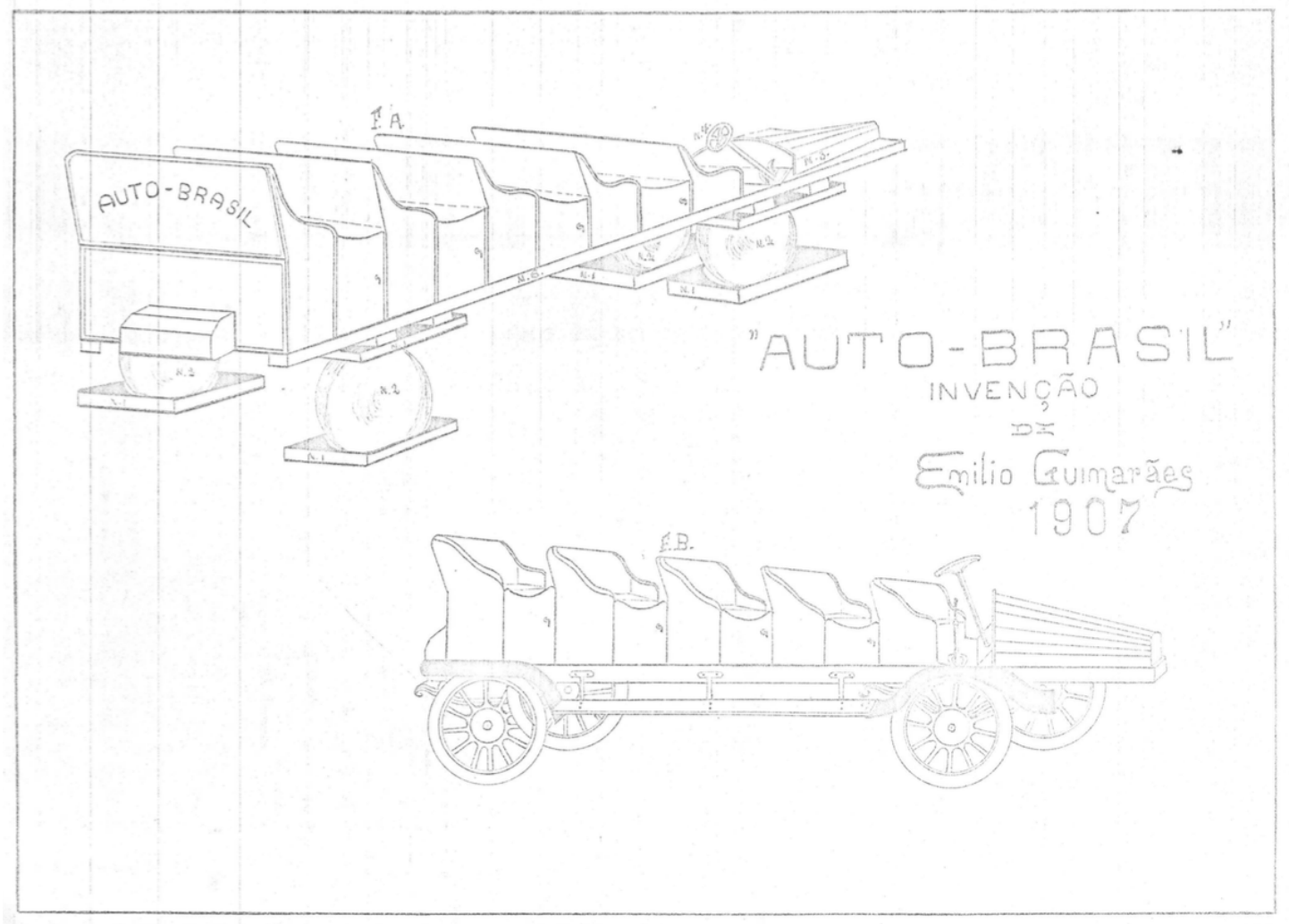

Figura 57 - Ilustração que acompanha o pedido de patente do “Auto-Brasil”. ${ }^{175}$

Observando a ilustração, podemos sugerir que o aparelho pudesse comportar de 10 a 15 pessoas, muito menos que as descrições dos Auto-Tours que, como vimos, faziam sentar

\footnotetext{
173 CINEMATECA BRASILEIRA (Org.). Coleção de memoriais descritivos acompanhando pedidos de privilégios e patentes de invenções relacionadas com o meio cinematográfico. Fornecida por José Inácio de Melo Souza a partir de pesquisa no Arquivo Nacional. Pasta D1329f, p. 2-3. Agradecemos a Alexandre Miyazato, bibliotecário da Cinemateca Brasileira, pela digitalização do documento.

${ }^{174}$ Idem, p. 3.

${ }^{175}$ Idem, p. 10.
} 
cerca de 30 espectadores-passageiros. É interessante notar, também, que há um assento na dianteira do veículo, com um volante, o que sugere a intenção Guimarães de ter um condutor durante as "viagens". Mas, sendo apenas uma ilustração para obtenção da patente, não nos permite afirmar que esteja mesmo ligada ao Cinema-Automóvel.

Os Auto-Tours e sua segunda versão, o Cinema-Automóvel, foram um tipo de sala de cinema diferente do que o público estava acostumado a ver. Por outro lado, seguia a tradição dos panoramas que utilizavam telas pintadas para dar a impressão, no espectador, de estar tomando parte em uma viagem por lugares distantes. Foram também muito próximas de sua matriz original, os Hale's Tours americanos, tendo lançado mão, como estes, de diferentes estratégias ilusionistas, como o uso de efeitos sonoros, filmes do tipo viagem fantasma, salas pequenas e a presença de um condutor para explicar as paisagens reproduzidas na tela.

\section{Viagem fantasma}

São pouquíssimos os relatos do público em nosso país, o que torna dificílima a análise desse setor. Se não temos nenhum relato brasileiro acerca dos filmes que mostram o trem avançar em direção à câmera, temos um interessante comentário sobre um filme do tipo viagem fantasma de um jornalista carioca de 1910:

\footnotetext{
Com a distância ou com a aproximação de cada poste - tudo está a deixar tal impressão de verdade que as pessoas fracas de estômago forçosamente hão de enjoar, como a bordo e nos caminhos de ferro. ${ }^{176}$
}

Então voltemos aos filmes do tipo viagem fantasma, que mostravam imagens tomadas de veículos em movimento, como carros, metrô e, principalmente, trens. O que é "fantasma" nos filmes de desse tipo - ou seja, o ambiente do seu ponto de vista - aparece materializado nos simuladores de viagem por meio da cenografia, de uma encenação que podia contar com atores, ruídos e movimentos reais, mas também e, talvez principalmente, por meio do endereçamento ao corpo do espectador.

Naquela época, muitos filmes realizados em nosso país parecem ter seguido as principais características do gênero de viagem. Apesar desses filmes não terem

\footnotetext{
${ }^{176}$ Gazeta de Notícias apud SOUZA, José Inácio de Melo. Imagens do passado: São Paulo e Rio de Janeiro nos primórdios do cinema. São Paulo: Editora Senac, 2004, p. 247.
} 
sobrevivido para que pudéssemos assistí-los e analisá-los, é por meio dos títulos e de algumas poucas descrições que podemos imaginar do que se tratavam. Há muitos exemplos ligados aos transportes modernos, como Chegada do primeiro automóvel a Curitiba (1907, PR) ou Inauguração das linhas elevadas (Casa Marc Ferrez, 1908, RJ), cuja sinopse diz ser um documentário de propaganda da Estrada de Ferro Central do Brasil. Outra propaganda da mesma companhia ferroviária, De Belém a Palmeiras (Casa Marc Ferrez, 1908, RJ), possivelmente continha planos tomados do interior de veículos, assim como Avenida Central apanhada de dentro de um automóvel (1907, RJ), exibido em Manaus, e Ascensão ao Pão-de-Açúcar (Empresa Paschoal Segreto, 1908, RJ). Muitos outros parecem ser vistas de pontos de interesse turístico, como Baía de Guanabara (Antonio Leal, 1907, RJ), Vistas de São Paulo e Santos (Empresa J. Cateysson, 1907, SP) e Belezas turísticas (A. Botelho Film, 1908, RJ). ${ }^{177}$

Foi um filme deste último tipo que, mesmo sem ter sobrevivido, causou polêmica na historiografia do cinema brasileiro, tendo sido responsável pelo estabelecimento do nosso próprio mito de origem. Como explica Bernardet, Alfonso Segreto (irmão de Paschoal), filmou "fortalezas e navios de guerra ancorados na baía" ${ }^{178}$ da Guanabara. Essa suposta filmagem, feita por "um italiano (...), com equipamento e material sensível europeus (...) em território francês (o paquete Brésil)" ${ }^{\prime 19}$, foi amplamente aceita como o "nascimento" do cinema brasileiro. O caso é um exemplo da ênfase que nossa historiografia deu, por décadas, à esfera da produção, ignorando os contextos de exibição dos filmes (ou mesmo ignorando se tinham sequer sido exibidos). De qualquer modo, o episódio sugere a importância que as vistas de pontos turísticos têm em nosso primeiro cinema.

\section{Última viagem}

Apesar de não serem tão importantes como as conhecidas empresas American Mutoscope \& Biograph, as de Edison e Sigmund Lubin, Selig Polyscope Company e American Vitagraph, os Irmãos Miles são citados por Charles Musser entre os mais

\footnotetext{
${ }^{177}$ Segundo a base Filmografia Brasileira da Cinemateca Brasileira, que pode ser consultada no sítio online: < http://cinemateca.org.br/filmografia-brasileira/ >.

${ }^{178}$ BERNARDET, Jean-Claude. Historiografia clássica do cinema brasileiro: metodologia e pedagogia. São Paulo: Annablume, 2008, p. 19.

${ }^{179}$ Idem, p. 20.
} 
influentes na organização das práticas do primeiro cinema norte-americano. ${ }^{180}$ Harry, Herbert, Earle e Joe Miles foram responsáveis pelo estabelecimento de uma das primeiras companhias de aluguel de filmes, prática que fez parte da estabilização de salas fixas de cinema nos Estados Unidos. Eles logo fizeram reputação nacional e expandiram o negócio para Nova Iorque, tornando-se a primeira companhia de aluguel de filmes a operar de costa a costa. Seu estúdio, o primeiro da costa oeste, instalado no número 1139 da Market Street, apesar de ter resistido ao terremoto de 1906, foi totalmente destruído em um dos incêndios que este causou. Ainda segundo Musser, "eles teriam sido, provavelmente, grandes produtores se o terremoto e o fogo não tivesse destruído suas instalações". ${ }^{181}$

Apenas um dia antes da tragédia, em 17 de abril, os irmãos Miles levaram os negativos de Uma viagem pela Market Street antes do incêndio para sua filial em Nova York. Foi nesse caminho (em um trem!), que eles ficaram sabendo do que estava acontecendo em São Francisco. Mandaram o filme para o destino previsto, que assim foi salvo, e retornaram com os equipamentos para registrar o desastre. Nas semanas seguintes ao terremoto, eles filmaram as ruínas, refugiados e o começo das reconstruções, ${ }^{182}$ filmes estes, aos quais não tivemos acesso sequer aos títulos. ${ }^{183}$

Segundo o jornal San Francisco Call, os irmãos Miles pediram permissão, em março de 1906, à companhia United Railroads, para utilizar alguns de seus bondes para fazer filmagens da Market Street. Sua intenção era exibir essas imagens na costa leste dos Estados Unidos e na Europa. ${ }^{184} \mathrm{O}$ pesquisador David Kiehn, que recentemente datou o filme, explica que uma câmera "foi colocada em um bonde elétrico (...) nas proximidades do estúdio dos Miles. Depois das três horas, naquela tarde ensolarada de sábado, a câmera a manivela registrou o caminho até o Ferry Building". ${ }^{185}$ Tanto Uma viagem pela Market

\footnotetext{
${ }^{180}$ MUSSER, Charles. The emergence of cinema: the american screen to 1907. Berkeley / Los Angeles: University of California Press, 1990, p. 9.

${ }^{181}$ Idem, p. 484.

182 Outro filme, de autoria desconhecia, "San Francisco earthquake and fire" (1906), apresenta imagens panorâmicas da cidade destruída, incluindo vistas da Market Street. Disponível em: < http://www.loc.gov/item/00694425 >. Acesso em: 20/07/2019.

${ }^{183}$ Essas informações, sobre o terremoto e a empresa dos irmãos Miles, foram retiradas das seguintes fontes: KIEHN, David. A trip down Market Street before the fire. Library of Congress. Disponível em: < http://www.loc.gov/programs/static/national-film-preservation-

board/documents/Trip\%20Down\%20Market\%20Street.kiehn.pdf >. Acesso em: 20/07/2019; Idem. The brothers who filmed the Earthquake. San Francisco Silent Film Festival. Disponível em: http://www.silentfilm.org/archive/the-brothers-who-filmed-the-earthquake. Acesso em: 20/07/2019.

${ }^{184} \mathrm{Em} 29$ de março de 1906. Notícia transcrita no sítio Cable-Car. Disponível em: < http://www.cable-carguy.com/html/ccatdms.html\#top >. Acesso em: 20/07/2019.

${ }_{185}$ KIEHN, David. A trip down Market Street before the fire. Library of Congress. Disponível em: < http://www.loc.gov/programs/static/national-film-preservation-

board/documents/Trip\%20Down\%20Market\%20Street.kiehn.pdf >. Acesso em: 20/07/2019.
} 
Street antes do incêndio quanto Uma viagem ao Monte Tamalpais (A Trip Down Mount Tamalpais), outro filme tomado de um carro em movimento, de 1906, feito pelos Miles, foram anunciados como tendo sido produzidos especialmente para os Hale's Tours. Mas, depois do terremoto, a demanda por imagens de São Francisco foi tão grande que eles criaram um programa de duas horas para ser acompanhado por um conferencista, que rodou o país e obteve grande sucesso. ${ }^{186}$

As versões que usaremos para a análise são duas: a disponível no sítio online da Library of Congress ${ }^{187}$ e a divulgada pelo sítio Internet Archive. ${ }^{188}$ A primeira parece ter sido retirada de uma cópia em VHS, o que pode ter contribuído para sua qualidade ser inferior (a imagem é bastante escura), mas a versão tem uma cartela inicial que a outra não tem. A segunda, apesar disso, é muito mais clara e tem fotogramas a mais no início e também no final. Ambas têm diversos cortes que apontam para a falta de alguns fotogramas ao longo do curta. Apesar disso, o filme parece ter-se constituído de um só plano-sequência. A duração da primeira versão é de 11 minutos e 6 segundos e, da outra, 12 minutos e 31 segundos.

O filme começa, então, com uma elegante cartela, na qual o título está escrito (figura 57). Ela aparece enquadrada de dois modos diferentes, separados por um corte seco, ambos apontando para o fato de que há perda de informação também nas laterais da imagem.

\footnotetext{
${ }^{186}$ KIEHN, David. A trip down Market Street before the fire. Library of Congress. Disponível em: < http://www.loc.gov/programs/static/national-film-preservationboard/documents/Trip\%20Down\%20Market\%20Street.kiehn.pdf >. Acesso em: 20/07/2019.

${ }^{187}$ Disponível em: < https://www.loc.gov/item/00694408 >. Acesso em: 20/07/2019.

188 Disponível em: < https://archive.org/details/TripDownMarketStreetrBeforeTheFire >. Acesso em: 20/07/2019.
} 


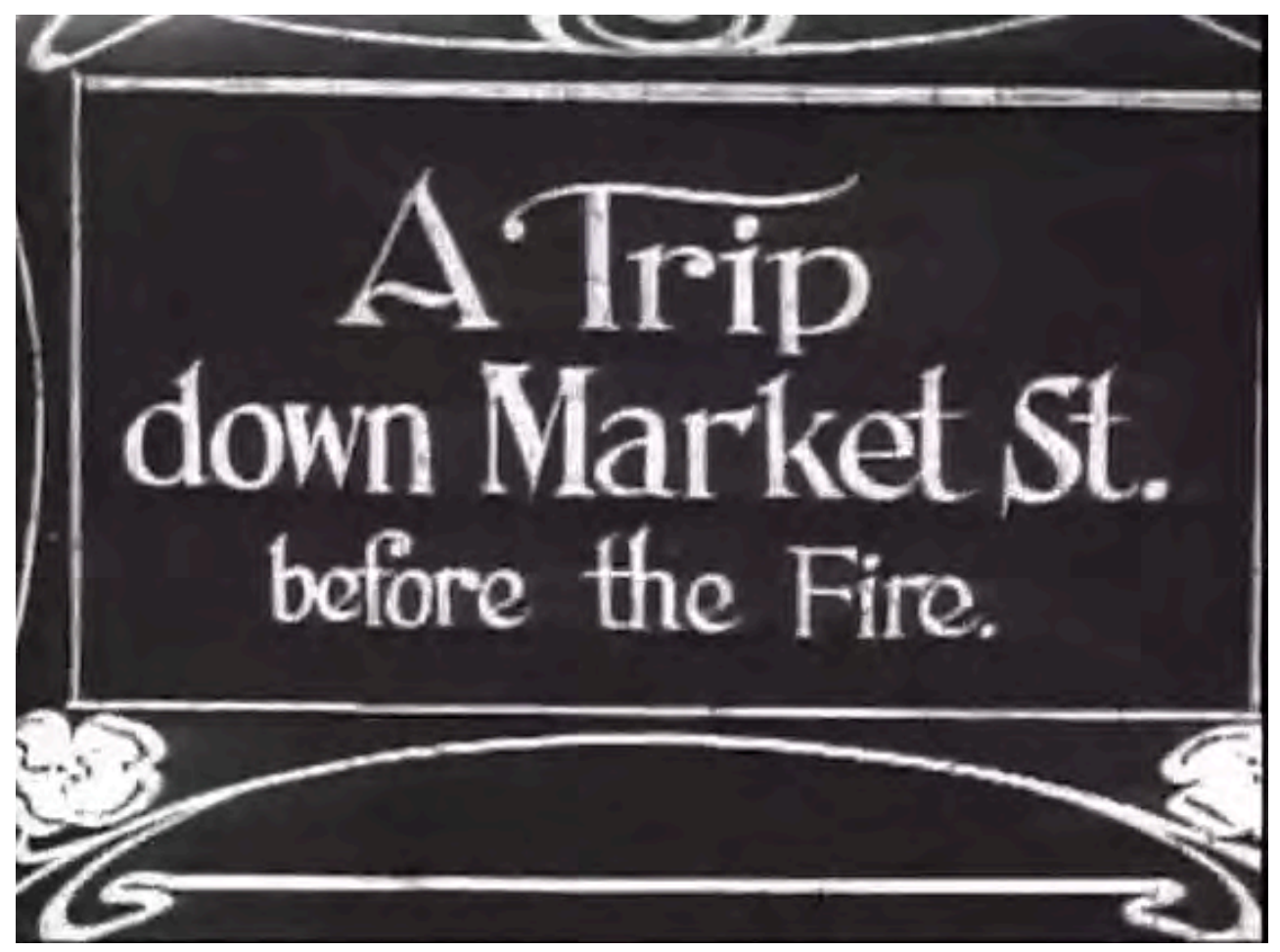

Figura 57 - Uma viagem pela Market Street antes do incêndio (Irmãos Miles, 1906).

Comecemos pelo título, onde já encontramos o respeito às convenções do gênero. Eram comuns os travelogues cujos títulos começavam com "a trip" (uma viagem). Um exemplo é A trip to the moon, título americano da viagem à lua de Georges Méliès. A trip through China (1902) e A trip through Samoa and the Fiji (Selig, 1905) são outros. Essas palavras já determinavam quais expectativas o espectador teria em relação ao programa de determinada sessão, que provavelmente incluiria viagens fantasma e vistas panorâmicas dos lugares referidos nos títulos. No nosso caso, além dos dois primeiros elementos "uma viagem" e "pela rua do mercado", temos também um terceiro, que aponta mais para o momento de divulgação que para o de produção, que é "antes do incêndio". Pois, quando o filme foi realizado, em 14 de abril de 1906, ninguém sabia que a cidade seria assolada, apenas 4 dias depois, por um terremoto e diversos incêndios. Foram mais de 3.000 mortos e pelo menos 200.000 desabrigados. Muitas das pessoas que vemos passar e dos edifícios que aparecem na tela provavelmente não sobreviveram ao desastre. O que era para ser uma vista comum do cotidiano da cidade, tornou-se o registro de vidas que foram completamente transformadas pouquíssimo tempo depois.

E, depois da cartela inicial, começa a nossa viagem. Vemos muitos elementos em quadro, como edifícios nas duas laterais, automóveis, carros de tração animal, pedestres, ciclistas. Todos em movimento constante e caótico. Dois elementos se mantêm: os trilhos 
no chão e a torre do Ferry Building, no centro da imagem, que aumenta na medida em que nos aproximamos dela. Nos filmes de vistas panorâmicas, era comum que o movimento da câmera enfatizasse a arquitetura da cidade. Os edifícios mais importantes, emblemáticos, eram focalizados de modo a conduzir o olhar do espectador para seus aspectos mais imponentes. Aqui, o olhar da câmera coincide com o do bonde: em relação a seu eixo, ela está sempre fixa; o que se move é o veículo, sempre seguindo seus trilhos. É a disposição de elementos em quadro mais comum nos filmes do tipo viagem fantasma (figura 58).

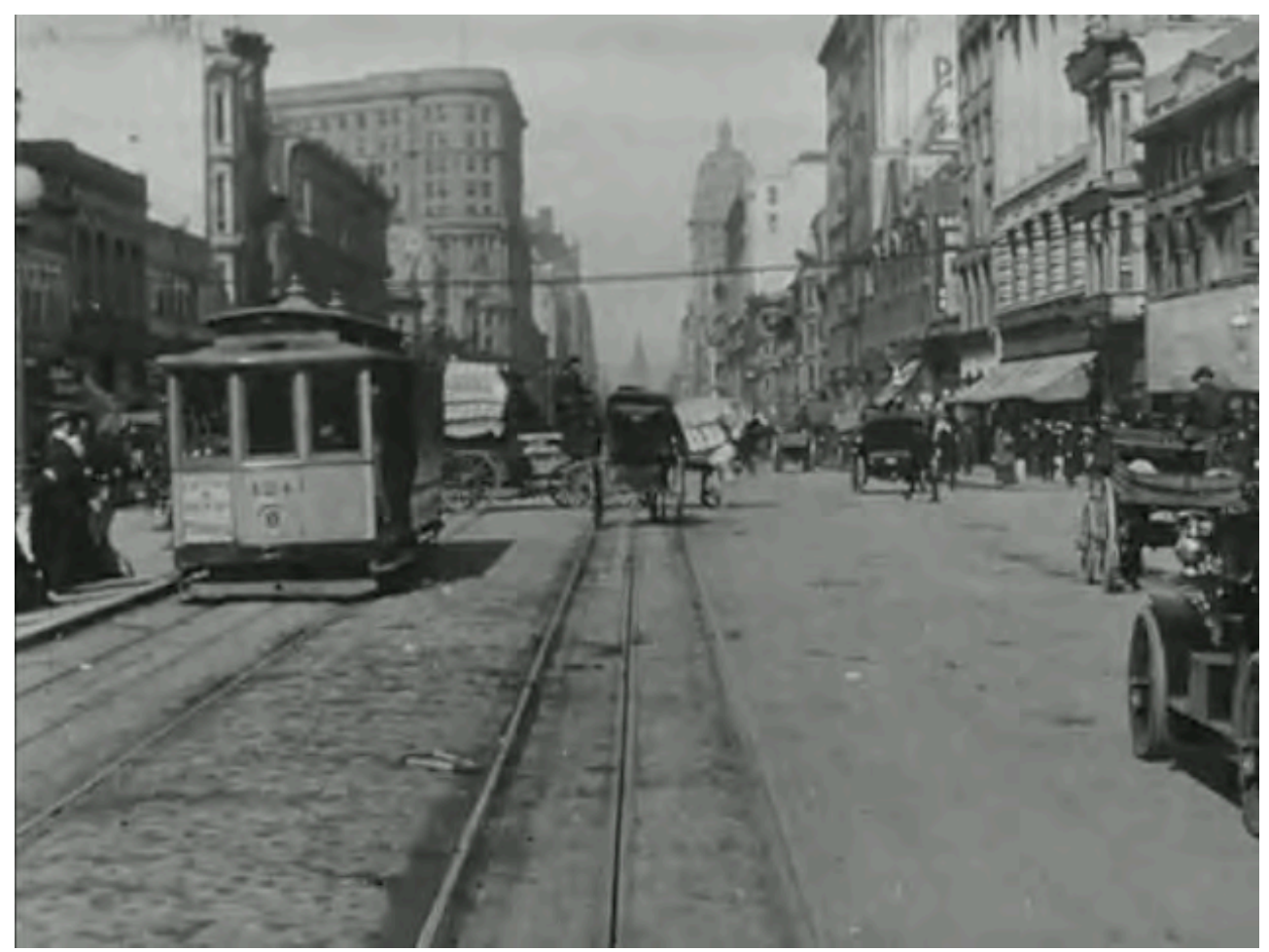

Figura 58 - Uma viagem pela Market Street antes do incêndio (Irmãos Miles, 1906).

Durante o trajeto, alguns bondes passam por nós e servem como espelho deste que é o nosso ponto de vista. Em dois casos podemos até ver, com certa clareza, os passageiros no interior dos veículos públicos. Segundo Rabinovitz,

não era incomum que os filmes [exibidos nos simuladores de viagem] fizessem cortes para o interior de um vagão de trem, produzindo uma "imagem espelho" do espaço social em que as pessoas estavam sentadas. Esses filmes (...) eram também sobre as relações sociais e expectativas relacionadas à experiência da viagem. ${ }^{189}$

${ }^{189}$ RABINOVITZ, Lauren. 'Bells and Whistles': The Sound of Meaning in Train Travel Film Rides. In: ABEL, Richard; ALTMAN, Rick (Eds.). The Sounds of Early Cinema. Bloomington: Indiana University Press, 2001, p. 176. 
Apesar de não ser exatamente o caso - não há cortes para planos que mostrem o interior de algum bonde -, é impossível não relacionar a vista de outros bondes ao próprio veículo que, apesar de não vermos nunca, nos leva por todo esse trajeto.

O ponto de vista da câmera, que coincide com o da dianteira do bonde, é diferente daquela que teriam os passageiros da viagem real e mesmo da de seu condutor. Ambos teriam acesso às laterais do veículo. Para nós, esse espaço está fora de quadro. Diversos veículos vêm e vão, não sabemos de onde. Para o espectador, são constantes surpresas. Esse efeito, produzido pelo filme, é potencializado pelo local de exibição, no caso de ser um simulador de viagens. Segundo Kiehn, “os automóveis são menos em número do que ao primeiro olhar, já que muitos deles passam, circundam o bonde e passam novamente. Um carro, (...) identificado pela placa de licença número 4867, passa 6 vezes". ${ }^{190}$ Além desse carro, há diversos outros momentos em que é possível perceber veículos circundando nosso bonde, o que sugere que os irmãos Miles tenham orquestrado uma encenação para fazer a Market Street parecer mais movimentada e moderna do que de fato era (figura 59).

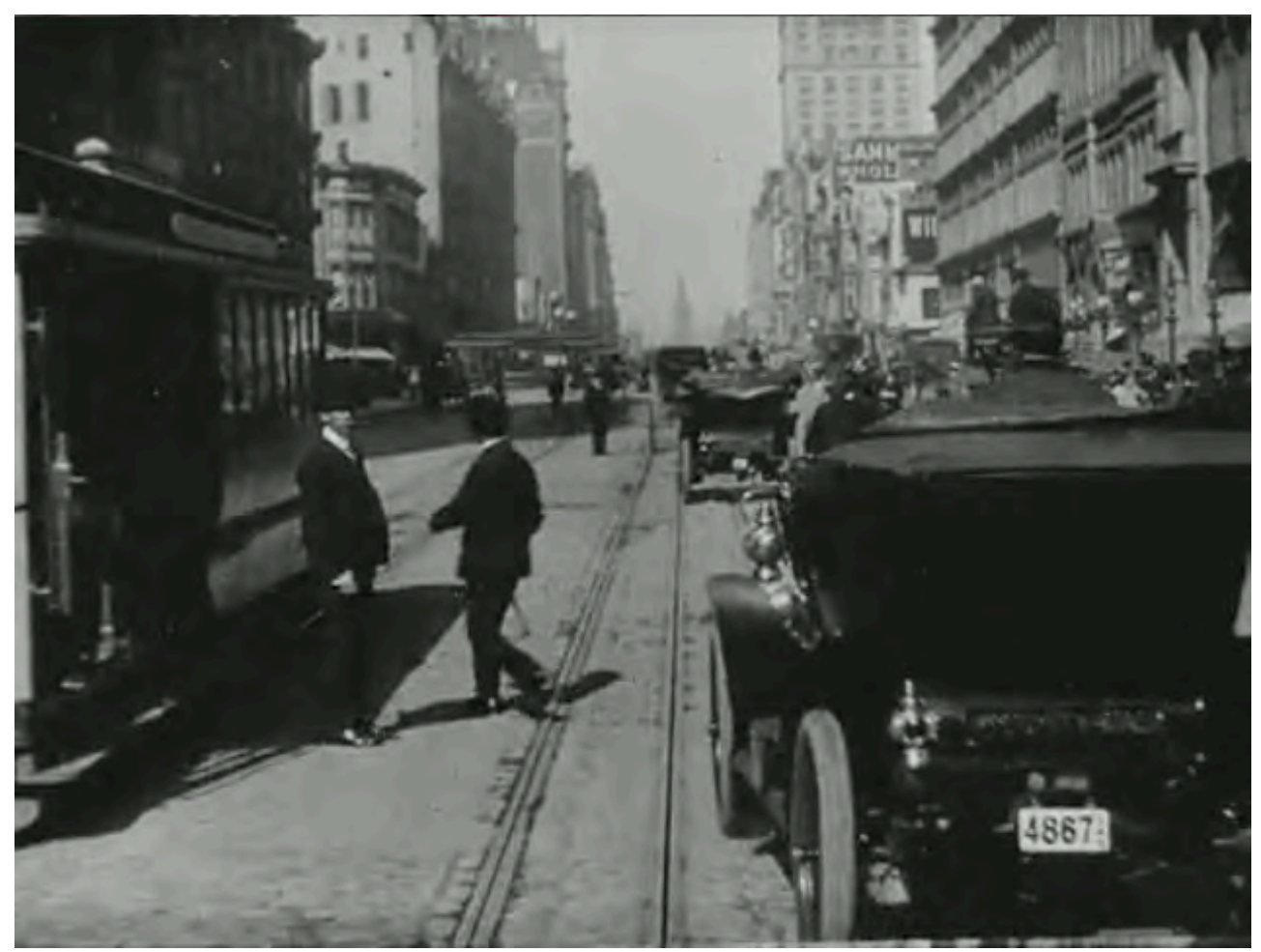

Figura 59 - Uma viagem pela Market Street antes do incêndio (Irmãos Miles, 1906).

${ }^{190}$ KIEHN, David. A trip down Market Street before the fire. Library of Congress. Disponível em: $<$ http://www.loc.gov/programs/static/national-film-preservation-

board/documents/Trip\%20Down\%20Market\%20Street.kiehn.pdf >. Acesso em: 20/07/2019. 
Em diversos momentos, pedestres passam muito perto de outros veículos, o que dá a impressão de que eles não são atropelados por pouco. Sabemos que era comum, nos tours simulados, que os efeitos sonoros fossem combinados aos eventos exibidos na tela. Rabinovitz explica que esses sons funcionavam como "'avisos ficcionais' [que,] coordenados com as aparições visuais de pedestres ou animais na rua ou nos trilhos, forneciam o envelope sonoro que tornava possível o realismo do passeio."191 Não é improvável que, no caso de uma projeção com a presença de um conferencista, este chamasse a atenção da plateia para isso, estimulando a ansiedade dos espectadores em relação aos perigos do trânsito moderno.

Os passantes também são responsáveis, com frequência, por olhares curiosos em direção à câmera, comumente acompanhados por sorrisos. Esses gestos são muito comuns em todo o primeiro cinema. É, inclusive, um dos aspectos que o diferencia do cinema posterior, dito "clássico". Não há constrangimento algum em relação a essas miradas diretas, pelo contrário: elas chamam a atenção do espectador para o interesse que tem a máquina (de filmagem) e, nesse caso, podem até remeter ao desejo por ver e ser visto que estava dominando os espaços públicos urbanos. Nossa passagem pela Market Street não é discreta, há toda uma movimentação fora do normal (vide os carros que circundam o bonde sem parar e a própria presença da câmera), o que chama a atenção dos passantes.

Durante todo o passeio, contribuem para o amontoado de elementos em quadro os enormes anúncios nas laterais dos edifícios, que são inúmeros. Todos esses estímulos sensoriais são responsáveis pela "turbulência sem precedentes [da qual fazem parte o] tráfego, barulho, painéis, sinais de trânsito, multidões que se acotovelam, vitrines" ${ }^{192}$

O elemento que se manteve no centro da imagem, finalmente se aproxima (figura $60) \ldots$

\footnotetext{
${ }^{191}$ RABINOVITZ, Lauren. 'Bells and Whistles': The Sound of Meaning in Train Travel Film Rides. In: ABEL, Richard; ALTMAN, Rick (Eds.). The Sounds of Early Cinema. Bloomington: Indiana University Press, 2001, p. 173.

${ }^{192}$ SINGER, Ben. Modernidade, hiperestímulo e o início do sensacionalismo popular. In: CHARNEY, Leo; SCHWARTZ, Vanessa R. (Orgs.). O cinema e a invenção da vida moderna. São Paulo: Cosac Naify, 2004, p. 96.
} 


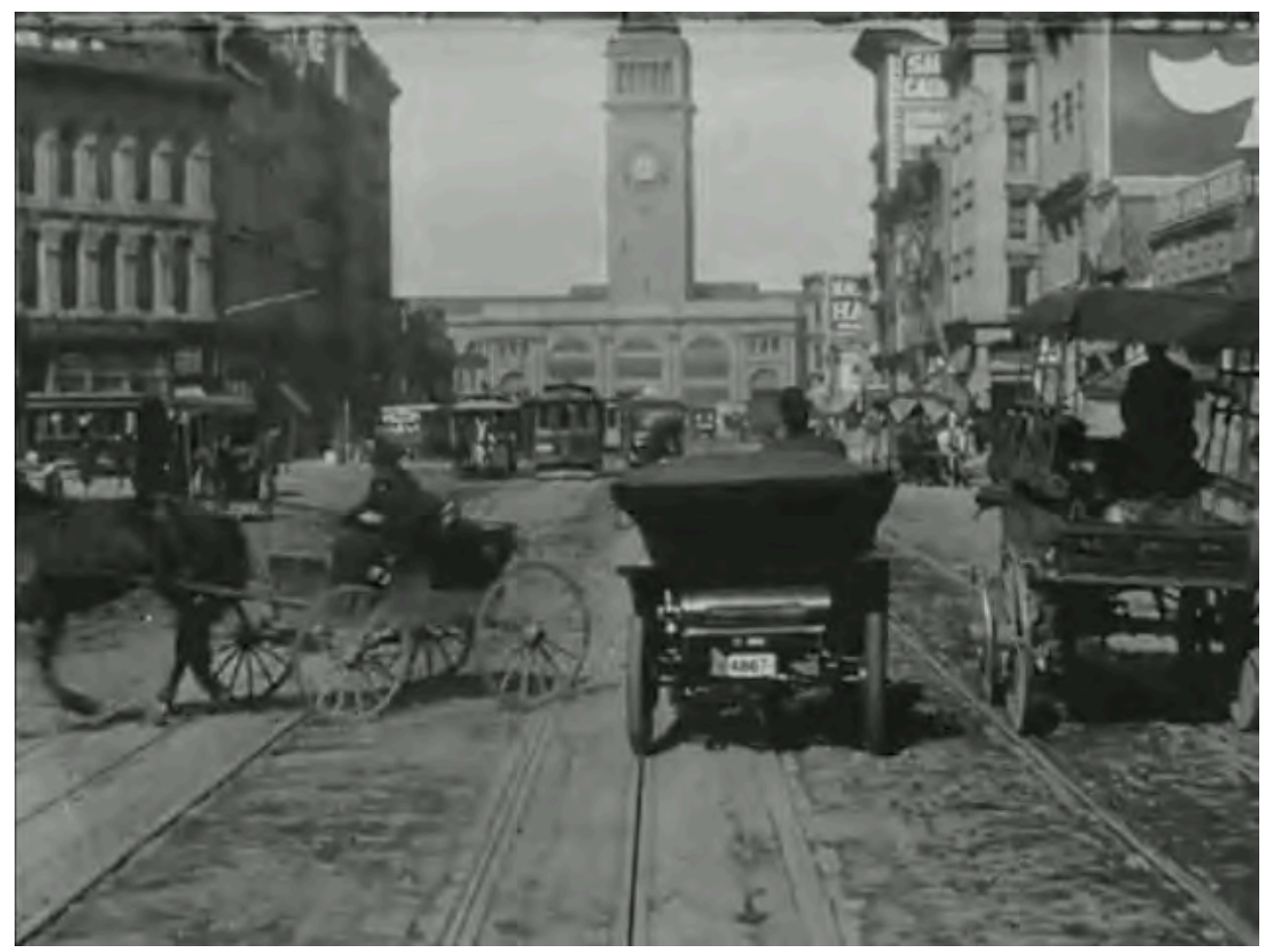

Figura 60 - Uma viagem pela Market Street antes do incêndio (Irmãos Miles, 1906).

E o bonde chega ao destino. O Ferry Building, onde se fazia a transferência entre transportes terrestres e balsas, sobreviveu ao terremoto, com poucos danos. Conforme nos aproximamos, temos a impressão de que o bonde entrará em colisão com a parede da estação - ou pior, com as pessoas que lá estão, encarando a câmera. Chega-se tão perto que é possível ler o escrito em uma das colunas, que diz que o edifício foi erigido em 1898. A câmera permanece parada nessa posição, por alguns segundos (figura 61). 


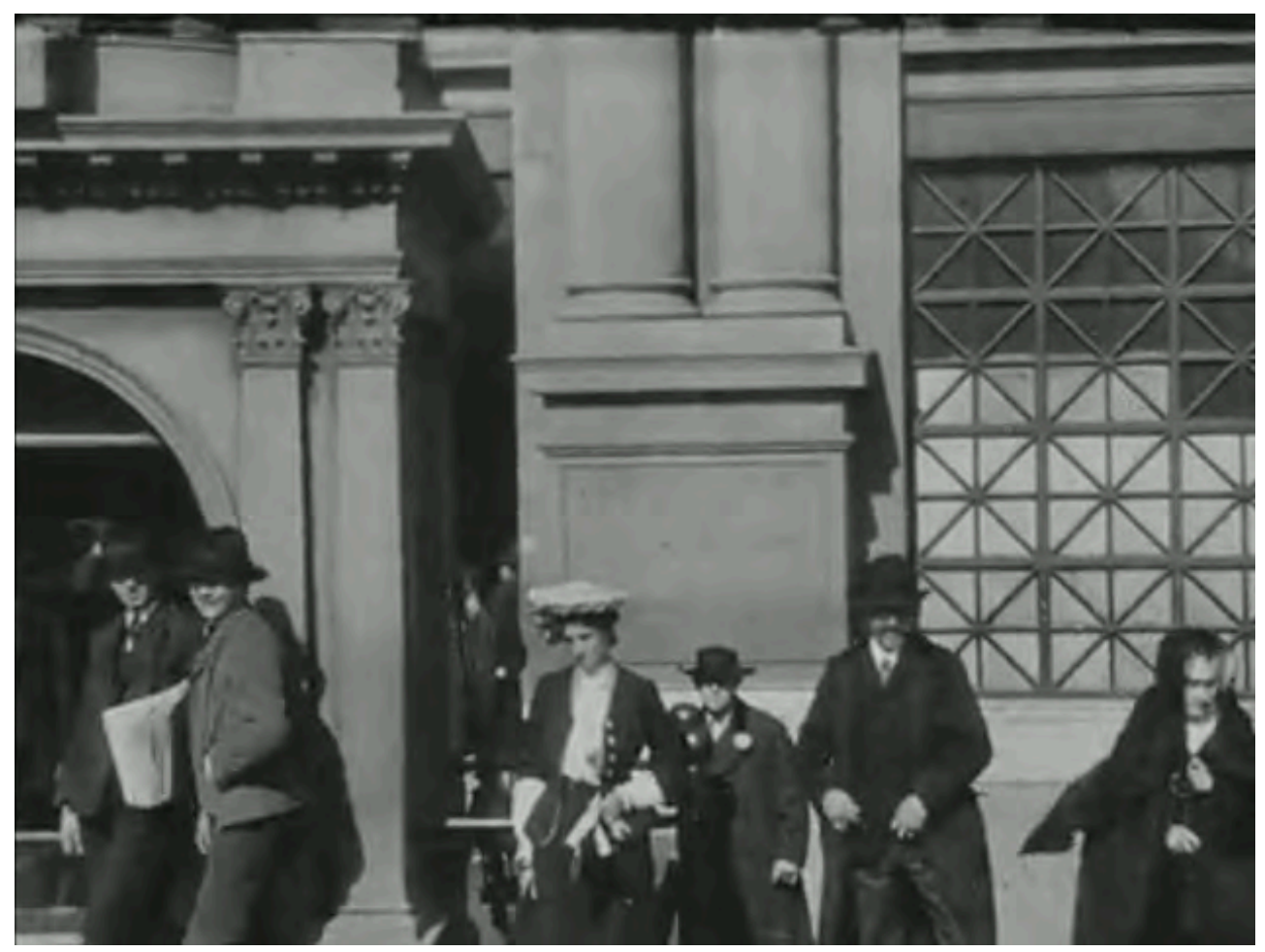

Figura 61 - Uma viagem pela Market Street antes do incêndio (Irmãos Miles, 1906).

E o bonde no qual nossa câmera está instalada parece estar agora numa plataforma que o faz girar em seu próprio eixo, para a esquerda. $\mathrm{O}$ que por fim a câmera passa a enquadrar é um contra-plano da Market Street, no qual vemos, do ponto de vista do Ferry Building, o caminho que acabamos de percorrer. Várias crianças nos surpreendem. Provavelmente esses meninos, vendedores de jornais, estavam atrás (ou nas laterais) do bonde, curiosos pelo evento de filmagem da rua. E, aqueles que os produtores buscavam esconder, finalmente aparecem, pulando, sorrindo, levantando seus chapéus (figura 62). 


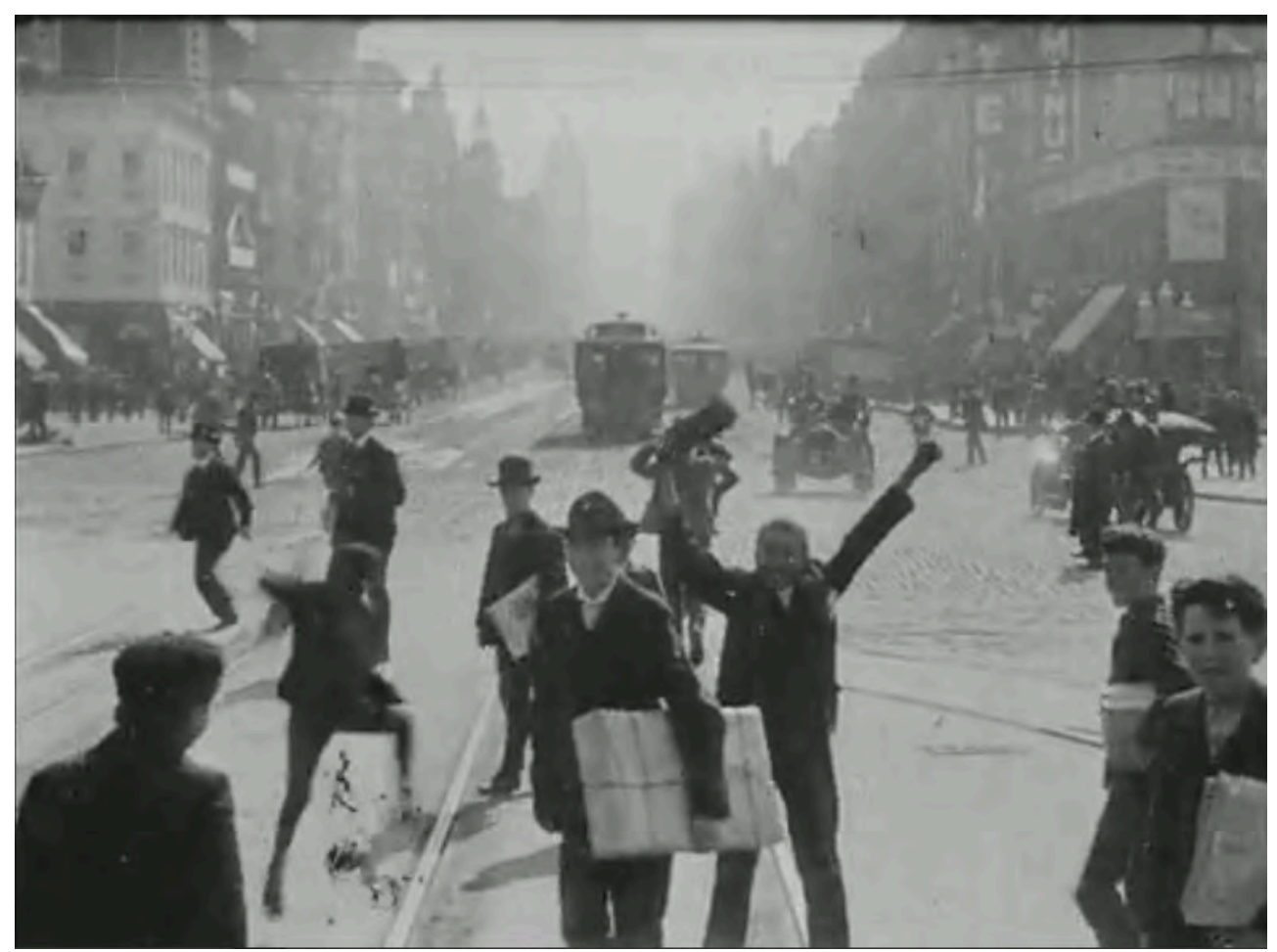

Figura 62 - Uma viagem pela Market Street antes do incêndio (Irmãos Miles, 1906).

Trânsito caótico de carros, bondes, cavalos, bicicletas, pedestres, avenidas largas cheias de numerosos anúncios, olhares curiosos, crianças vendendo jornais e a própria velocidade do trajeto. São todos signos da modernidade que desorientava ao mesmo tempo que encantava o indivíduo, cada vez mais bombardeado por estímulos diversos. A experiência da vida pública estava se transformando, criando novos perigos e desejos. Um deles, o de consumir esses mesmos signos através de imagens.

Os Hale's Tours, entretenimento barato ligado às classes baixas dos Estados Unidos, permaneceu excluído das histórias do cinema até os anos 1970. ${ }^{193}$ Muito diferente disso, parece que os simuladores de viagem fizeram parte, no Brasil, de uma elevação da sala de cinema a um espaço digno da presença da elite. Como buscamos explicitar na análise de comentários de época sobre o Ferro-Carril Asiático e os Auto-Tours, o sucesso que as atrações tiveram nos Estados Unidos e Europa, independente das classes sociais que lá a frequentavam, foi o suficiente para divulgá-las como atrações próprias para o público "inteligente e civilizado". Os simuladores de viagem que por aqui passaram foram vistos frequentemente como formas de participação de nosso país no que havia de mais

193 GAUTHIER, Philippe. The movie theater as an institutional space and framework of signification: Hale's Tours and film historiography. In: Film History 21, no. 4, 2009. 
moderno na época. Não podemos deixar de lembrar da máxima "o Rio civiliza-se", cunhada pelo literato da Belle Époque carioca Figueiredo Pimentel, que diz muito do desejo que a elite carioca passou a ter nesse momento de mostrar-se, por meio de uma “espetacularização social e cultural”, como parte de uma cidade cosmopolita integrante da modernidade em curso nos países centrais. ${ }^{194}$ Mas há nesse esforço, é claro, uma idealização de um progresso, que não se tinha e que se buscava atingir.

Do mesmo modo que a encenação fez parecer, no filme A trip down Market Street before the fire, que a cidade de São Francisco tivesse um trânsito mais intenso de automóveis do que de fato tinha, os simuladores de viagem criaram uma espécie de cena, na qual os espectadores tomavam parte como se fossem atores. Pois viviam, no espetáculo, a simulação de uma vida que não era deles. Os simuladores representaram, portanto, não só a possibilidade de viajar sem sair do lugar, como também o acesso à sensação de velocidade com a segurança que não se tinha nas ruas. Ansiedade e prazer, medo e curiosidade, todos esses sentimentos fazem parte da relação que se estabeleceu entre espectadores e essas atrações que buscavam o acesso à "coqueluche dos novos tempos", ${ }^{195}$ o turismo.

\footnotetext{
${ }^{194}$ SOUZA, José Inácio de Melo. Op. Cit., p. 44; CARVALHO, Danielle Crepaldi. Luz e sombra no écran: realidade, cinema e rua nas crônicas cariocas de 1894 a 1922. Tese (Doutorado em Teoria e História Literária) - Unicamp, 2014, p. 106.

${ }^{195}$ SEVCENKO, Nicolau. A capital irradiante: técnica, ritmos e ritos do Rio. In: História da vida privada (v. 3) - República: da Belle Époque à Era do Rádio. São Paulo: Cia. das Letras, 1998, p. 559.
} 


\section{Terceiro capítulo}

\section{Os caipiras vão à Exposição Nacional: percurso imaginário de um filme perdido}

Na primeira página do Jornal do Brasil de 25 de agosto de 1908, foi anunciado o lançamento de um filme chamado Sô Lotero e nhá Ofrasia com seus productos na Exposição. ${ }^{196}$ Alguns dias depois, na Gazeta de notícias, o cronista Figueiredo Pimentel o indicou a seus exigentes leitores, descrevendo-o como uma "fita engraçadíssima, nítida, perfeita, que recomendamos, certos de seu sucesso". ${ }^{197}$ A empresa produtora era Labanca, Leal e Cia. e a estreia aconteceu no Cinema-Palace, sala de propriedade da mesma empresa, que ficava na rua do Ouvidor, na cidade do Rio de Janeiro. O operador, Antônio Leal, trabalhara como fotógrafo para a imprensa carioca e já havia realizado filmes de grande sucesso. ${ }^{198}$ Como indicam os pouquíssimos comentadores que já o mencionaram, ${ }^{199}$ o filme teria sido uma comédia ambientada no espaço da Exposição Nacional Comemorativa do $1^{\circ}$ Centenário da Abertura dos Portos do Brasil, que, entre 11 de agosto e 15 de novembro daquele ano, recebeu mais de um milhão de visitantes oriundos de diversas partes do país. O casal que protagoniza o filme, natural da região rural de São Paulo, já seria conhecido do público desde pelo menos 1906, quando apareceu na revista teatral $O$ maxixe, de autoria de D. Xiquote e João Phóca. E isto é quase tudo o que a princípio se sabe sobre esta fita que se perdeu. ${ }^{200}$

Sô Lotero e nhá Ofrasia com seus productos na Exposição faz parte de um gênero bastante popular no primeiro cinema, o dos filmes de caipira, que fazia graça do encontro entre personagens rurais e assuntos urbanos os mais diversos. Aparelhos telefônicos, parques de diversão, todos os meios de transporte modernos ou a própria multidão que

\footnotetext{
196 Jornal do Brasil, 25/08/1908, p. 1.

197 PIMENTEL, Figueiredo apud ARAÚJO, Vicente de Paula. A Bela Época do Cinema Brasileiro. São Paulo: Editora Perspectiva, 1976, p. 264.

${ }^{198}$ Os estranguladores, por exemplo, teve pelo menos "830 apresentações contínuas, alcançando 20 mil espectadores somente no primeiro mês" (SOUZA, José Inácio de Melo. Imagens do passado: São Paulo e Rio de Janeiro nos primórdios do cinema. São Paulo: Editora Senac, 2004, p. 247).

${ }^{199}$ TINHORÃO, José Ramos. A música popular no romance brasileiro Vol. III: século XX, $2^{\mathrm{a}}$ parte. São Paulo: Editora 34, p. 126; AUGUSTO, Sérgio. Este mundo é um pandeiro: a chanchada de Getúlio a JK. São Paulo: Companhia das Letras, 1989, p. 85.

${ }^{200}$ Apenas cerca de $7 \%$ da produção brasileira durante todo o período silencioso sobreviveu. SOUZA, Carlos Roberto de. Estratégias de sobrevivência. In: PAIVA, Samuel; SCHVARZMAN, Sheila (Org.). Viagem ao cinema silencioso do Brasil. Rio de Janeiro: Beco do Azougue, 2011.
} 
habita as cidades: os caipiras do primeiro cinema reagem confusos, deslumbrados, aterrorizados - e quase sempre terminam por estragar tudo. Ao colocar em cena esses tipos desacostumados à cidade grande, esses filmes tematizam as ambiguidades de um encontro que não é protagonizado apenas pelos caipiras, mas por todos que vivemos transformações que descartam formas de vida sem cessar.

O filme que será nosso objeto de análise neste capítulo não pode ser descrito diretamente, dada sua ausência. Para aventar suas características, por meio da análise de material fílmico e não fílmico, faremos sugestões de como teriam sido as personagens, o roteiro, os cenários e a recepção de Sô Lotero e nhá Ofrasia.... Ao longo do texto, acompanharemos os caipiras em sua visita à Exposição, comentando cada ponto por onde teriam passado, como teriam sido suas reações e como teriam reagido os espectadores da época às imagens.

\section{Os caipiras vão ao Rio de Janeiro - e nós também}

"Fica já sabido que temos diante de nós dous caipiras legitissimos, virgens de todo o contacto de civilisação" - assim são apresentados sô Lotero e nhá Ofrasia no que talvez seja sua primeira aparição na cultura carioca. A citação é do romance folhetinesco Os caipiras, assinado pelo literato santista João Phóca e ilustrado por Bambino e Amaro. É por esta narrativa seriada, publicada aos domingos no Jornal do Brasil, que começaremos a estabelecer algumas características das personagens que mais tarde serão protagonistas de nosso filme. No primeiro episódio (intitulado "Prologo: a 'sólte' grande"), publicado em 4 de dezembro de 1904, elas são descritas como "honestas e singelissimas creaturas, innocentes como agua de chuva". ${ }^{201} \mathrm{O}$ narrador não sabe dizer quando nasceram, mas seu endereço é localizado com certa precisão: o sítio dos caipiras ficava no "valle de Lençóes", "pouco abaixo da cidade do mesmo nome, partindo de S. Manuel do Paraizo", interior de São Paulo. A narrativa começa com um acontecimento extraordinário, que muda drasticamente a vida pacata do casal. Lotero ganha na loteria a quantia de cinco contos de réis, equivalente ao que seriam hoje cerca de 600 mil reais (figura 63). E o caipira já sabe o que fazer com tanto dinheiro: "Cinco conto!... Você sabe

${ }^{201}$ PHÓCA, João. Os caipiras (Illustrações de Bambino e Amaro). Romance de João Phóca. Prologo: a "sólte" grande. Jornal do Brasil, 04/12/1904, p. 3. 
quanto é cinco conto?... É uma porçoada de dinheiro... Dinheiro que nem cisco, dinheiro que inté fede!... E sabe o que é que a gente vamo fazê? Vamo ver o Rio de Janeiro...”. ${ }^{202}$

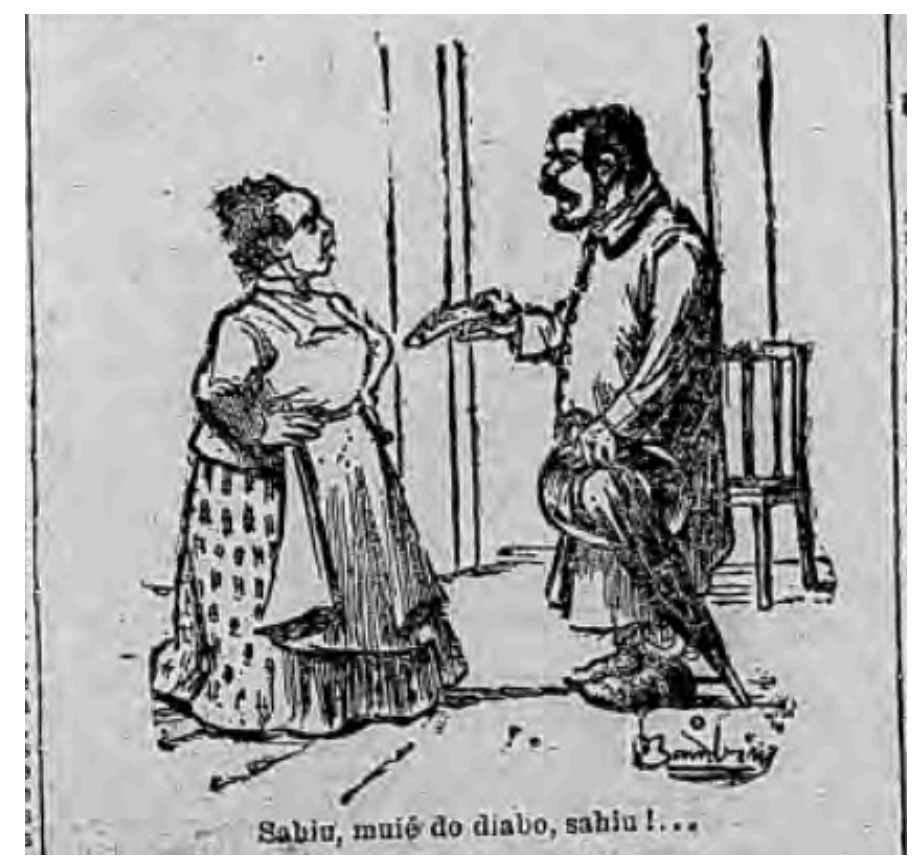

Figura 63 - Os caipiras. Jornal do Brasil, 04/12/1904, p. 3.

No dia seguinte, os dois vão a uma loja de roupas. Lotero compra um "frack" justo "a ponto de lhe cortar o sovaco" e Ofrasia "quasi morre suffocada" ao experimentar um vestido. A mulher adquire também todo um figurino, que inclui "chapéo, um véo, um guarda-sol vermelho, uma bolsa e uns sapatos de bico que lhe punham os pés, acostumados aos tamancos e aos chinellos, em petição de miseria". Na madrugada do mesmo dia, seguem em um "troly" rumo a São Paulo, "aos solavancos". "Moidos da viagem", 203 chegam à capital paulista. Nhá Ofrasia tem medo da locomotiva, mas aceita embarcar, depois de muita relutância. E então começa o trajeto cujo destino final é o Rio de Janeiro. No vagão já em movimento, ao tentar tirar o espartilho que a esmagava, o balanço da máquina leva Ofrasia ao chão, e a mulher vira alvo de chacota dos outros passageiros. Ela acaba por despir-se tanto do colete, como dos sapatos que a torturavam. Toda essa indumentária parece deformar os corpos dos caipiras (figura 64). Do mesmo modo, eles são afetados pelos meios que os transportam, que os sacodem e derrubam. É como se o mundo urbano já começasse a influenciá-los antes mesmo de sua chegada à cidade, maltratando-os, constrangendo-os, descaracterizando-os.

\footnotetext{
202 Ibidem.

203 PHÓCA, João. Os caipiras (Ilustrações de Bambino e Amaro) Romance de João Phoca. A viagem. Jornal do Brasil, 11/12/1904, p. 3.
} 


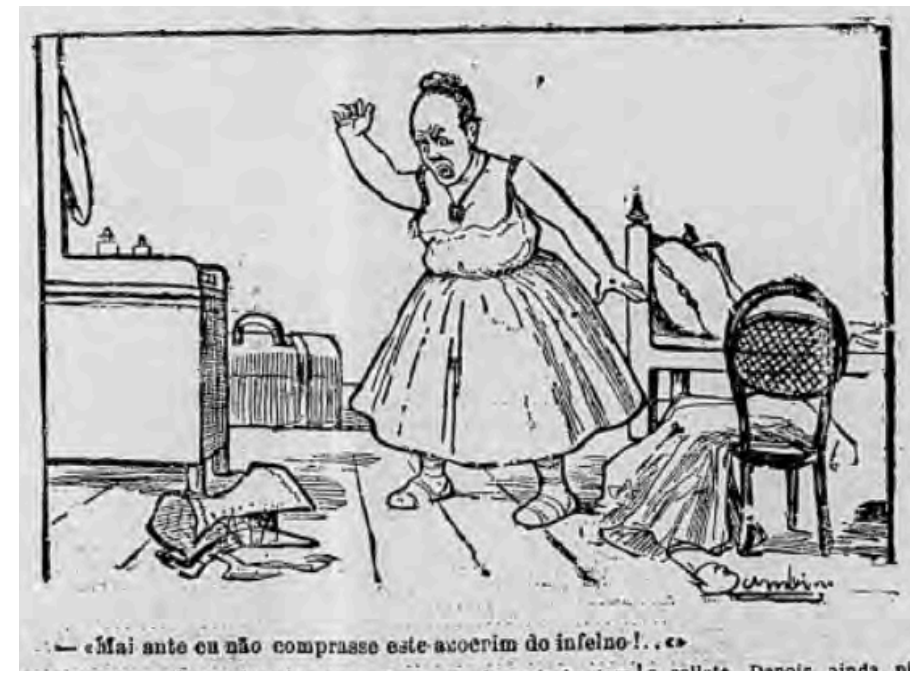

Figura 63 - Nhá Ofrasia e seu espartilho em Os caipiras. Jornal do Brasil, 25/12/1904, p. 3.

Toda a primeira parte de Os caipiras (cujos capítulos seguiram sendo publicados até pelo menos 13/12/1908) é dedicada às suas peripécias na primeira visita ao Rio, que incluem a prisão temporária do casal, a fuga de sô Lotero com uma francesa, seu posterior arrependimento e o perdão de nhá Ofrasia. ${ }^{204}$ A segunda parte é anunciada em uma crônica de João Phóca, de fevereiro de 1907, quando do retorno do autor de uma viagem que já durava mais de seis meses. ${ }^{205}$ Em fins de novembro de 1908 é publicado finalmente o primeiro capítulo da parte dois do folhetim, intitulado "Volta ao Rio para a Exposição; o juramento delle; novo programma de vida". ${ }^{206}$ O regresso do casal à cidade é motivado justamente pela Exposição Nacional (que na realidade já havia encerrado suas atividades fazia quase dez dias), sobre a qual os dois tinham ouvido muito falar. João Phóca, também personagem do romance, narrando tudo em primeira pessoa e referindo-se a si com frequência, começa contando que recebera uma carta anônima, remetida de São Paulo, na redação do Jornal do Brasil. O texto, enigmático, dizia “espere estação Sem Trá”.

No dia seguinte, o narrador vai à Estação Central do Rio de Janeiro e é surpreendido pela chegada dos caipiras. Em determinado ponto do encontro, Ofrasia e Phóca conversam sobre a primeira visita do casal à cidade:

[Ofrasia] - (...) O que as fota e toda gente léva a dizê da Insposição pegô a fazê umas cóscas em nóis, pegô a nos attentá que não pudemo arresisti. Sô Lotero

\footnotetext{
${ }^{204}$ Mais uma vez, aparece a mulher como um dos perigos urbanos a que os caipiras estão expostos na cidade.

${ }^{205}$ PHÓCA, João. Ora vivam!... Jornal do Brasil, 12/02/1907, p. 4.

206 Jornal do Brasil, 23/11/1908, p. 6.
} 
d'um lado, eu do outro fiquemo n'um assanhamento p'rá vi que arresorvemo a coisa em treis tempo...

[Phóca] - E não tem medo mais desta "terra de peldição" como a senhora chamava o Rio?

[Ofrasia] - Medo tenho e p'ro molde isso, antes de vir, levei sô Lotero na Matriz e fiz elle jurá, ajoelado diante da image de São Bão Jesuis de Pirapóra que havéra de se poltá dereito. Elle jurô, c'as mão nos peito. E ó depois eu tenho um prano...

[Phóca] - Ah! tem!?

[Ofrasia] - Tenho... Num vê que elle me contô que o que siduziu elle na tá franceza do infelno - ella e o intaliano, que ambos, sô Phoca? - foi a chiqueza da diaba. Polque, veldade se diga, a diaba se vestia-se mêmo na hora e a cara era uma pintura. Entãoce vendo que é isso que agrada elle, eu tô resorvida a me botá tamem no chiquismo. Já sei que vô castigá o colpo co tá vandroaes esses espartios modelnos - e tudo mais, mas tô resorvida a me vesti e me pintá como as franceza, pr'elle não tê rasão de queixa... ${ }^{207}$

O que levou o casal de caipiras de volta ao Rio foram os comentários e as fotografias (as "fota") acerca da Exposição Nacional de 1908 a que tiveram acesso no interior de São Paulo. E, outra vez, a ida à capital federal afeta seus corpos, principalmente o da mulher, desde o princípio. Nesse sentido, é significativo que a personagem relacione a viagem às cócegas causadas pelas notícias da Exposição e no decorrente assanhamento, palavra que remete a um desejo sexual "incontrolável". O medo, sentimento que aparecia com frequência na primeira temporada do folhetim, é fundamental para a lógica narrativa aqui também. É o medo de perder o marido que faz Ofrasia a obrigá-lo a jurar, de joelhos, que se vai se comportar. Além disso, seu temor a leva a criar um plano para evitar que o marido se envolva novamente com uma mulher citadina: ela pretende vestir-se do mesmo modo que a "franceza do infelno". É a oposição clichê entre o campo, lugar onde sobrevive certa pureza, e a cidade, "terra de perdição". E mais uma vez o vestuário aparece como uma espécie de materialização do mundo urbano: Ofrasia opta por "castigar o corpo" usando espartilhos para agradar ao marido e, assim, proteger o núcleo familiar dos perigos urbanos, representados por mulheres "diabas".

Outro aspecto que se destaca no trecho transcrito é a diferença entre os discursos em diálogo. A linguagem usada pela personagem caipira é caricata e permeada de um vocabulário específico. São frequentes no texto, por exemplo, a troca da letra "l” em final de sílaba pela "r" (e vice-versa), como em arresorvemo e resorvida; poltá, modelnos, infelno, polque, veldade e colpo. É uma maneira de representar, na escrita, o fenômeno fonético chamado pela sociolinguística variacionista de rotacismo, comum em linguagens consideradas "populares" na língua portuguesa. Interessante notar que, enquanto o

207 Jornal do Brasil, 23/11/1908, p. 6. 
discurso de Ofrasia é representado de modo a parecer o mais próximo possível de uma oralidade, as falas do narrador-autor seguem a norma culta, no padrão da modalidade escrita da língua ${ }^{208}$ - mesmo que na modalidade falada até um jornalista dos anos 1900 provavelmente também omitisse alguns fonemas finais de palavras ou coisas do tipo. $\mathrm{O}$ uso de tais recursos linguísticos reforçam a enorme desigualdade que existe entre as representações do cronista e dos caipiras. Em resumo, João Phóca pinta seu casal em um tom condescendente. Sô Lotero e nhá Ofrasia são "virgens", "inocentes", suscetíveis às "perdições" urbanas; têm medo dos meios de transporte modernos; seus corpos não se adequam ao figurino urbano; e sua linguagem é "tosca".

Até agora, buscamos apresentar algumas características dos protagonistas de nosso filme perdido, suas motivações para visitar o Rio de Janeiro e as experiências sensoriais implicadas nessas viagens. Mas cabe perguntar como tudo isso teria sido representado nas imagens de Sô Lotero e nhá Ofrasia com seus productos na Exposição. Para começar a mergulhar de fato na reconstituição da obra, vale a pena trazer à tona um outro título, também perdido: Nhô Anastácio chegou de viagem (Arnaldo e Cia., 1908), operado por Julio Ferrez e lançado em junho de 1908, dois meses antes da estreia de Sô Lotero e nhá Ofrasia.... A personagem de Nhô Anastácio parece ter tido maior repercussão na cultura brasileira. ${ }^{209}$

Figueiredo Pimentel descreve Nhô Anastácio... como uma série de "cenas de um roceiro recém-chegado a esta Capital. Muito bem feita, muito curiosa. É a primeira vez que se fazem entre nós, fitas desse gênero". ${ }^{210}$ Uma importante pista de como seriam tais cenas está nos títulos dos quadros do filme, reproduzidos pela Filmografia Brasileira: "A Partida; Embarque na Estação; Chegada à Estação da Estrada de Ferro Central do Brasil; Visita à Caixa de Conversão; O Palácio Monroe; O Passeio Público; O Namoro e a Carta da Cantora; A Denuncia; Volta Súbita da Esposa; Perseguição e Reconciliação Geral". ${ }^{211}$ São evidentes as semelhanças com a história de nosso casal: tanto no filme como na primeira parte do folhetim as personagens começam com a saída do campo, passam pela Central do Brasil, começam a adaptar-se (adaptação representada em Nhô Anastácio...

\footnotetext{
${ }^{208}$ Salvo raras exceções, normalmente simples contrações, como o uso de "p'ra", em vez de "para".

${ }^{209} \mathrm{Um}$ exemplo bastante posterior é o caipira interpretado por Oscarito na comédia $O$ homem do Sputnik (Atlântida, Carlos Manga, 1959), também chamado Anastácio. Cf. MATTOS, Carlos Alberto. Coisas nossas. Notas sobre alguns gêneros tipicamente brasileiros. Disponível em: < http://www.bcc.org.br/textos/225970 >. Acesso em: 10/07/2019.

${ }^{210}$ ARAÚJO, Vicente de Paula. A Bela Época do Cinema Brasileiro. São Paulo: Editora Perspectiva, 1976, p. 250.

${ }_{211}$ Segundo a sinopse de Nhô Anastácio chegou de viagem, Filmografia Brasileira da Cinemateca Brasileira.
} 
pela caixa de conversão, espécie de casa de câmbio da época), visitam pontos turísticos, os homens se envolvem com mulheres urbanas (no folhetim, uma francesa; aqui, uma cantora), o que causa problemas com as esposas, que terminam por perdoar em nome de uma reconciliação final.

Ou seja, é provável que o filme Sô Lotero e nhá Ofrasia... tivesse estrutura semelhante. Seguindo mais ou menos os mesmos passos de Anastácio e munidos da caracterização do casal caipira extraída do folhetim, acompanharemos sô Lotero e nhá Ofrasia em sua visita ao Rio. Já passamos pelos primeiros quadros da narrativa quando comentamos a partida, o percurso e a chegada dos caipiras. Continuaremos com a chegada a um hotel, a parada em uma confeitaria da moda e, claro, a tão esperada visita à Exposição Nacional, com ingresso garantido às suas principais atrações.

\section{“Tão mudados estavam, com as novas paisagens"}

Voltando ao romance seriado de João Phóca. A busca por hospedagem é narrada da seguinte maneira:

\footnotetext{
Era o carro estacar em frente de um hotel e o hoteleiro logo nos barrar. Tive receio de que elles estivessem a fazer pouca fé com o pessoal, por verem os dous assim mal ajambrados. Sim, porque, quem vê cara, não vê carteira e sô Lotero póde ter ares de tudo menos de pessoa abonada, de homem hervado, ${ }^{212}$ que está bem com Deus e falla francez como gente grande.

Assim em toda parte onde paravamos eu saltava logo e ia direito ao hoteleiro dizer-lhe no ouvido:

- Elles estão sujinhos, mas têm arame p'ra burro!

Nem assim. Tudo cheio, tudo quanto era hotel e pensão assim mais tal. ${ }^{213}$
}

Depois de três horas rodando pelas ruas da cidade em uma carruagem, os caipiras encontram pouso em uma hospedaria na Rua do Nuncio (atual República do Líbano), a apenas oito quadras da luxuosa Avenida Central (atual Rio Branco). Durante todo o percurso, nhá Ofrasia reclama de dores nos pés e recorda o tanto que teve de caminhar na primeira visita à cidade. O que a consola desta vez é andar sentada em carruagem puxada por burros. Ao finalmente entrar no estabelecimento, relembram do hotel onde se hospedaram na primeira visita ao Rio, quando Lotero teria confundido as portas dos quartos e entrado no alojamento de uma mulher desconhecida. Tanto o modo como a procura é descrita, e o tempo que as personagens gastam nessa tarefa quanto o caso da

\footnotetext{
${ }^{212}$ Ervado, "cheio de erva (no sentido de 'dinheiro'); endinheirado", segundo o dicionário Houaiss.

${ }^{213}$ Os Caipiras. Romance comido de João Phoca, Ilustrações de Bambino. Segunda parte. Sô Lotero ô Nhá Ofrasia na Exposição, I: Á percura do Hote. Jornal do Brasil, 29/11/1908, p. 10.
} 
troca de portas constroem a imagem de uma cidade lotada de turistas, labiríntica e traiçoeira. É a terra da perdição, mas agora no sentido mesmo de perder-se numa profusão de caminhos e possibilidades que confundem e enganam.

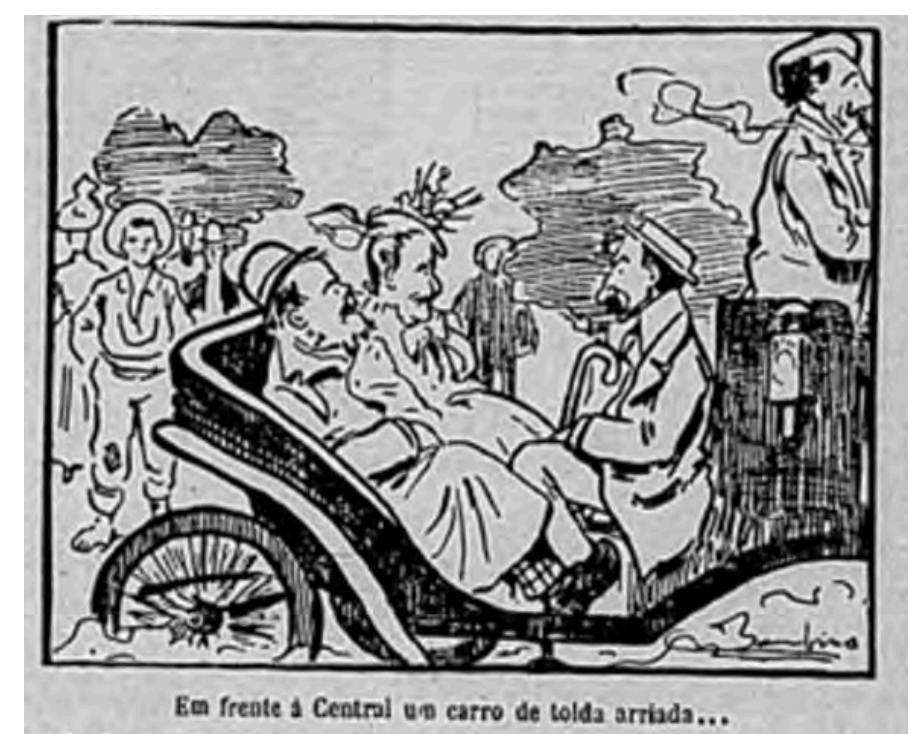

Figura 64 - Sô Lotero, nhá Ofrasia e João Phóca à procura de um hotel em Os caipiras. Á percura do Hote. Jornal do Brasil, 29/11/1908, p. 10

Depois de terem descansado no hotel, Lotero e Ofrasia foram novamente às compras, e adquiriram "cousas assombrosas". ${ }^{214} \mathrm{Um}$ dado interessante aparece nesta segunda temporada do folhetim: os caipiras começam a adaptar-se, em certa medida, à cidade, adaptação marcada pelo consumo, vale dizer. No dia seguinte à chegada, na Avenida Central, o casal encontra Phóca, que quase não os reconhece "tão mudados estavam, com as novas paisagens". Nhá Ofrasia usava "um vestido ulta-moderno [e] um frack que lhe ficava como uma luva...". Mas a adaptação não é completa. O narrador continua: a mulher usava "um chapéo roda de carro, com toda uma loja de fitas e mais um espanador em cima, suando como uma louca e já manquejando”, ou seja, mancando. Lotero "vestia um terno côr de macaco, paletot cintado, calça bocca de sino e chapéo de côco (...). De longe parecia um inglez... traduzido para cassange." "Caçanje”, no dicionário, consta como "indivíduo negro escravizado, trazido ao Brasil a partir da região de Caçanje (Angola)". Por extensão, em uso pejorativo, racista, a palavra teria o sentido de "português errado, mal falado ou mal escrito". ${ }^{215}$ O ajuste dos corpos dos caipiras à lógica urbana, portanto, é sempre representado no folhetim como incompleto, capenga,

${ }^{214}$ PHÓCA, João. Os Caipiras. Romance comico de João Phoca, Ilustrações de Bambino. Segunda parte. Sô Lotero e Nhá Ofrasia na exposição, II: Encadernados de novo. Jornal do Brasil. 13/12/1908, p. 10

215 Segundo o verbete "caçanje" no dicionário Houaiss. 
mal feito. Parece haver algo em seus corpos que denuncia sua origem, independente de seus esforços.

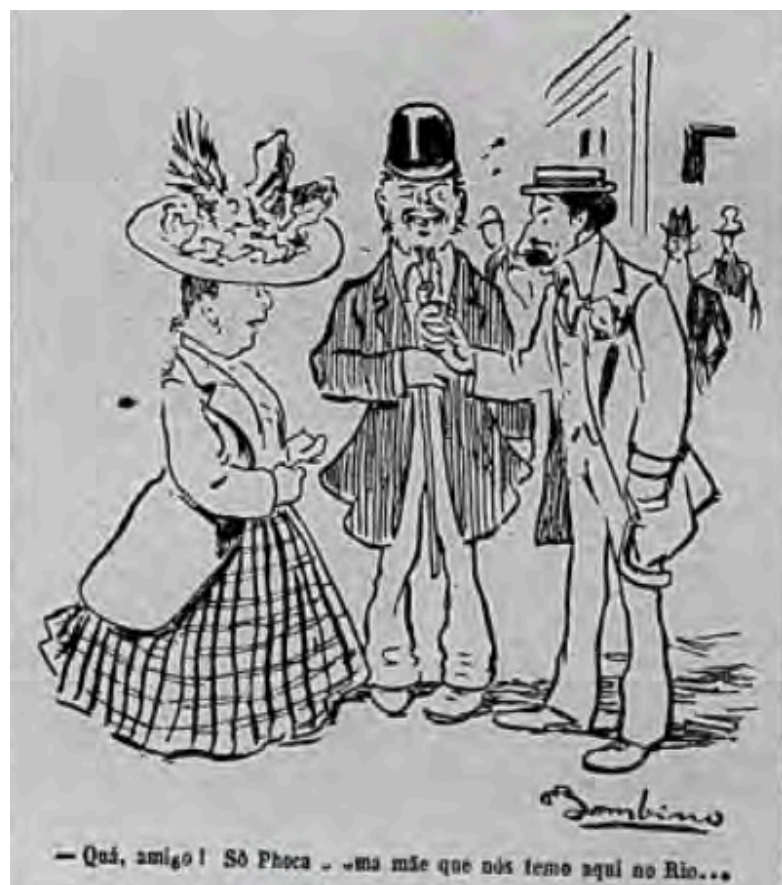

Figura 65 - O encontro dos três na Avenida Central em Os Caipiras. Nhá Ofrasia, Sô Lotero e João Phóca. Jornal do Brasil. 13/12/1908, p. 10.

$\mathrm{Na}$ avenida (figura 66), eles conversam:

[Lotero] - Tamo querendo i já e já na Insposição. Nóis viemo pr’a vê ella, já vê que tá trocando pelnas e cauçando os pezes aqui é bobagem...

[Ofrasia] - E pol fallá em pezes se a gente fosse nos assentalmos? Eu tou cos meu aldendo que parece que levaro um sinapismo de arregalou...

Sô Lotero, oppoz-se. Para ir para a Exposição tinham de ir sentados, já vê que era só perder tempo isso de entrar num café ou numa confeitaria. ${ }^{216}$

Ofrasia quer descansar, Lotero não quer perder tempo. Logo seguiremos com eles, rumo à Exposição. Mesmo que eles tenham decidido não parar, podemos tomar o episódio como gancho para fazer uma passagem rápida pelas confeitarias, uma das novas atrações do "novo equipamento urbano" da burguesia carioca, que trocava as varandas e salões coloniais pelos encontros nas avenidas, pela agitação dos automóveis e pelas promessas do comércio. ${ }^{217}$ As confeitarias são citadas nos jornais da época por seus menus de pratos franceses, pelos encontros da elite literária que lá aconteciam, pelos brindes lá oferecidos

${ }^{216}$ Os Caipiras. Romance comico de João Phoca, Ilustrações de Bambino. Segunda parte. Sô Lotero e Nhá Ofrasia na exposição, II: Encadernados de novo. Jornal do Brasil. 13/12/1908, p. 10

217 SEVCENKO, Nicolau. Literatura como missão: tensões sociais e criação cultural na Primeira República. São Paulo: Brasiliense, 1983, p. 37. 
a políticos estrangeiros, pela venda de ingressos para eventos da elite e por outras atividades consideradas elegantes que lá tomavam lugar. Eram lugares ligados ao ócio e ao prazer, onde podia-se tomar um chá importado, bebidas alcóolicas ou refrescos, comer docinhos franceses etc. Diferentemente de João Phóca, que estaria familiarizado a esse tipo de ambiente, os caipiras provavelmente "causariam problemas" por não performar o comportamento esperado, como veremos. Em um episódio anterior do folhetim, o casal vai a um restaurante e é ridicularizado pelos outros clientes. Os caipiras quebram peças de louça, nhá Ofrasia grita de susto e, tentando imitar um freguês, Lotero "dá um banho" em sua esposa com o sifão de água com gás (figura 67).

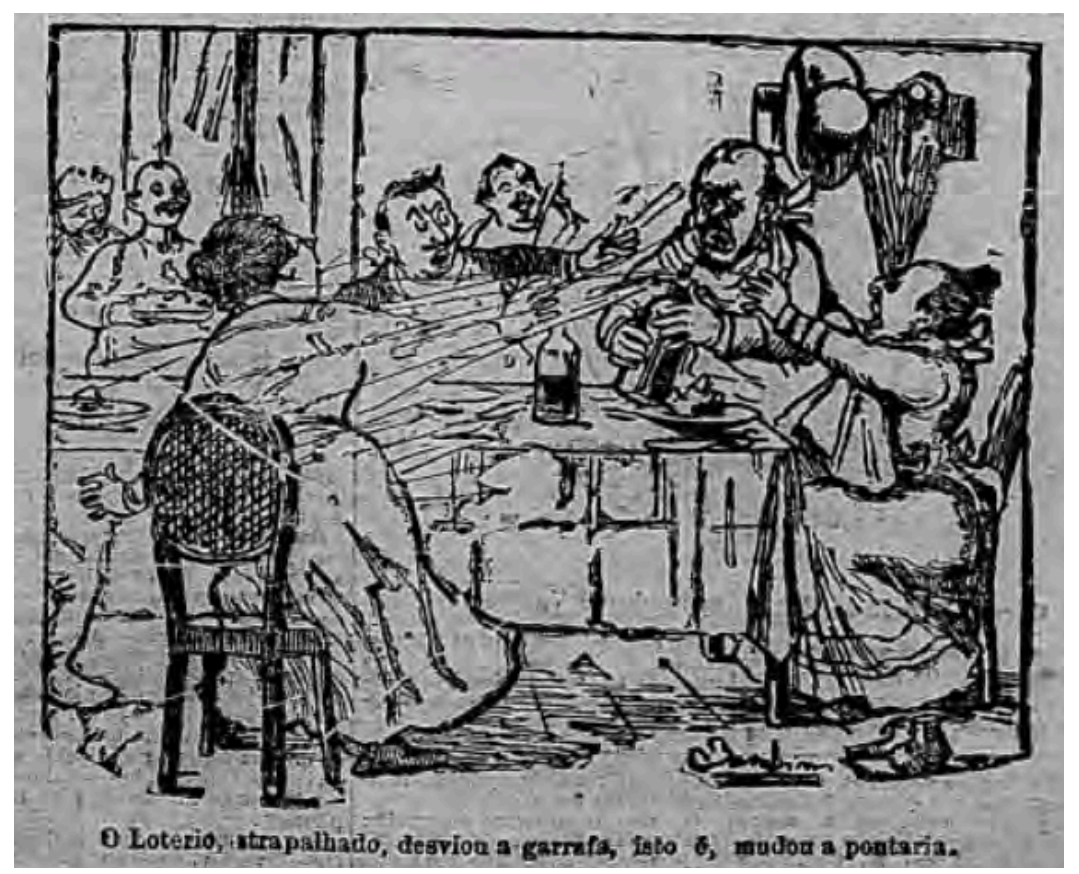

Figura 66 - Lotero dá banho de água com gás em sua esposa em Os Caipiras. Jornal do Brasil. 18/12/1904, p. 1.

Sempre, quando na cidade grande, os caipiras parecem destoar da paisagem. Não é difícil imaginar, então, que algo semelhante acontecesse com nossas personagens caso passassem por uma confeitaria, que não era um tipo de restaurante comum. Tomemos como exemplo a Colombo, fundada em 1894 e a mais famosa de todas, que existe até hoje na Rua Gonçalves Dias, conhecida por sua detalhada decoração interior, que conta com enormes espelhos de cristal. Uma matéria publicada na revista Careta, em janeiro de 1909, nos ajuda a adentrar o recinto por meio da descrição que o escritor faz da chegada de seu entrevistado, um político: 
Na confeitaria, de pé, na muda contemplação da sua figura reflectida em diversos espelhos, n'uma multiplicidade infinita, porque são fronteiros uns aos outros, estava o cidadão desejado: havia uma infinita quantidade de Arthur Ambrosino Heredia de Sá, nos quatro cantos, depois nos fundos doutros espelhos reflectidos, depois mais outros, até não se divisar mais nada (...). Aproximei-me do sr. Heredia em carne e osso, do authentico, do deputado $(\ldots) .^{218}$

A quantidade e o posicionamento dos espelhos da confeitaria multiplicam infinitamente o corpo do tal político, evidenciando sua presença e, ao mesmo tempo, possibilitando a confusão entre corpo material e corpo de imagem. Ele é um "cidadão desejado".

A crônica "Modern girls", publicada por João do Rio em janeiro de 1910 no jornal Gazeta de notícias, também se passa na Colombo. ${ }^{219}$ Os espelhos aparecem novamente como peça importante do cenário - não para destacar a figura de um homem ilustre, como no exemplo anterior, mas para revelar o caráter "degenerado" de uma mulher. Duas meninas, dois rapazes e uma senhora entram no recinto depois de um passeio de automóvel. O narrador e seu amigo, sentados em uma mesa próxima, observam.

\footnotetext{
A menor, rindo, approximou-se do espelho.

- Mas que vento! que vento! Estou toda despenteada...

Mirou-se. Instinctivamente olhamos para o espelho. Era uma carita de criança. Apenas estava muito bem pintada. As olheiras exaggeradas, as sombrancelhas augmentadas, os labios avivados a carmim liquido faziam-lhe uma apimentada mascara de vicio. Era de certo do que gostava, porque sorriu á propria imagem, fez uma caretinha, lambeu o labio superior e veiu sentar-se, mas á ingleza, traçando a perna. ${ }^{220}$
}

A menina, que "teria doze [anos] no maximo", 221 é descrita de modo grotesco. Suas feições são tão grandes que parecem não caber em seu rosto de criança. É através do espelho que tal descrição é feita e é no espelho que sua "mascara de vicio" se manifesta para a visão externa. Logo depois, ela pede um chope e um sujeito de quarenta anos lhe entrega um envelope por debaixo da mesa. Enquanto o amigo descreve a cena como uma "perdição", o narrador diz que a menina é "um expoente da vida nova, a vida do automovel". E continua: "certo, há muitissimas raparigas puras. Mas estas, que se transformaram com o Rio, estas que há dez annos tomariam sorvete, de olhos baixos e acanhadas, estas são as 'modern girls"'. ${ }^{222} \mathrm{Na}$ visão do narrador, as transformações pelas quais a cidade passou repercutem direta e explicitamente nos corpos das garotas. E a

\footnotetext{
${ }^{218}$ Revista Careta, 23/01/1909, p. 11.

${ }^{219}$ RIO, João do. Modern girls. Gazeta de notícias, 30/10/1910, p. 1

${ }^{220}$ RIO, João do. Modern girls. In: Vida vertiginosa. Rio de Janeiro: Livraria Garnier, p. 88.

${ }^{221}$ Idem p. 87.

${ }^{222}$ Idem, p. 88.
} 
origem disso é clara: "o que Paris e Lisboa e Londres, emfim as cidades européas offerecem tão naturalmente, prolifera agora no Rio". A frase poderia servir para falar das próprias confeitarias ou do cinema, por exemplo, mas é seguida de "a miseria deshonesta manda as meninas, as crianças, para a rua e explora-as". ${ }^{223}$ E termina com: "ellas são modernas, ellas são coquettes, ellas querem apparecer, brilhar, superar".

A confeitaria espelhada é um espaço privilegiado para aparecer. Os espelhos multiplicam os campos de visão, ampliando as possibilidades para espiar e fiscalizar os gestos alheios. Ponto de encontro de literatos e boêmios, o ambiente incentiva os atos de ver, ser visto e mesmo o de admirar-se sendo visto através dos inúmeros reflexos. No caso do político da revista Careta, a decoração do ambiente salienta a aparente grandeza de sua figura. Já no caso da menina da crônica de João do Rio, ao contrário, o que se destaca é sua pequenez moral. Como em uma sala de espelhos, atrações que criam múltiplas imagens distorcidas dos visitantes de parques de diversões, a confeitaria modifica a imagem dos corpos que ali adentram. Mas isso não acontece de maneira simétrica. Como vimos, das diferenças de gênero decorrem diferentes representações. Em nossos exemplos, o homem moderno é vultoso; a mulher que se moderniza é decadente. As trapalhadas de nossos caipiras, sob os espelhos e olhares da confeitaria, ganhariam uma espécie de lente de aumento, destacando seu desajuste ao contexto. Lotero, descrito como homem "de menor categoria", que não é "gente grande", não parece ser do tipo que teria sua grandiosidade ampliada pelos espelhos. Ofrasia, por ser mulher, menos ainda. Se em Sô Lotero e nhá Ofrasia com seus productos na Exposição nosso casal de caipiras passasse por uma confeitaria, a visita seria representada provavelmente como um tremendo vexame.

Voltemos à cena que se passava na Avenida Central, onde deixamos Lotero, Ofrasia e Phóca algumas páginas atrás. Finalmente o casal ruma para a Exposição.

[Lotero] - Onde é que fica a tá de Insposição?

[Phóca] - No fim da Avenida Beira Mar, na praia Vermelha.

[Lotero] - Praia Vremeia?... Não me alembro de nunhuma dessa col? (...)

Entãoce pr'a Insposição o bonde que se toma é dos de Botafogo?

[Phóca] - É. Eu vou com vocês até o ponto delles e os faço embarcar...

Muito obrigado... O senhor é um amigo de veldade - declarou nhá Ofrasia.

- Qual amigo! Sô Phóca é uma mãe que nós temo aqui no Rio... affirmou sô Lotero. $^{224}$

\footnotetext{
${ }^{223}$ RIO, João do. Modern girls. In: Vida vertiginosa. Rio de Janeiro: Livraria Garnier, p. 91.

${ }^{224}$ Os Caipiras. Romance comico de João Phoca, Ilustrações de Bambino. Segunda parte. Sô Lotero e Nhá Ofrasia na exposição, II: Encadernados de novo. Jornal do Brasil. 13/12/1908, p. 10
} 
Phóca é um mediador. Na relação entre caipiras e cidade, o narrador-personagem recebe o casal na estação, negocia com os funcionários dos hoteis, os conduz pelas ruas do Rio. Na relação entre caipiras e leitores, Phóca nos dá o significado de palavras do vocabulário roceiro e nos descreve as reações dos outros às confusões do casal. Chamá-lo "mãe" é mais uma vez diminuir os caipiras, infantilizando-os ao implicar que eles não teriam capacidade de se cuidar sem ajuda na cidade. Sua visita à tão esperada Exposição é o que tentaremos recriar a seguir.

\section{A volta ao Brasil em um dia}

"Procurando fazer um trabalho completo e de consulta facil, foi o nosso intuito prestar um serviço ás pessoas que desejarem fazer á Exposição visitas proveitosas, economisando tempo, e libertando-se do auxilio de ciceroni." 225 Assim dizem os editores do Guia Official da Exposição Nacional de 1908, no prefácio da publicação. Abandonando a figura do narrador-mediador, passaremos então a acompanhar alguns pontos do roteiro prescrito pelo livrinho e por outros materiais, como álbuns e notícias de jornal. Neles, encontramos descrições detalhadas dos edifícios, informações sobre preços e meios de locomoção, fotografias, mapas e ilustrações.

A "primeira maravilha que prende a attenção dos visitantes"226 é a Porta Monumental, construída especialmente para a Exposição. Sua estrutura, de madeira, era composta por um grande arco central, encimado pelas armas da República, e apoiado em quatro colunas. Suas cores eram violeta, rosa e amarelo. A iluminação da Porta era composta de oito mil lâmpadas incandescentes e trinta de arco a vapor de mercúrio também coloridas, acompanhando as cores de cada parte de sua estrutura (figura 68).

\footnotetext{
${ }^{225}$ GUIA official da Exposição Nacional de 1908. Rio de Janeiro: Tavaresa Oliveira, 1908, p. 3.

${ }^{226}$ Idem, p. 97.
} 


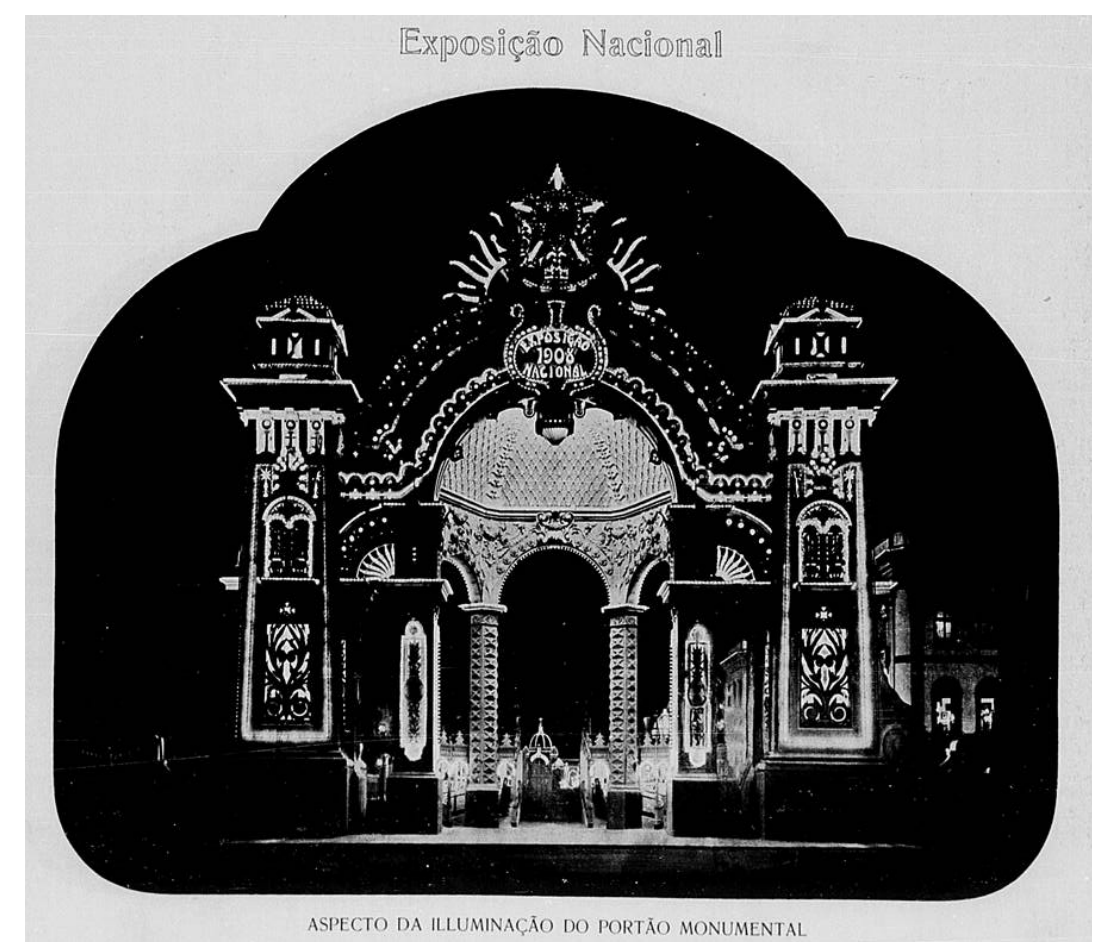

Figura 67 - Revista Kosmos. Ano 5, No. 4, agosto de 1908, p. 25.

Esses portais, segundo Ruth Levy, "sempre tiveram papel de destaque nas diversas exposições, já que eram responsáveis por um impacto inicial, um primeiro contato do público com a exposição". ${ }^{227}$ O exemplo mais conhecido é a torre de Gustave Eiffel, construída em ferro para servir de entrada para Exposição Universal de Paris de 1889. Com seus 324 metros de altura, ela foi a estrutura mais alta do mundo até 1930. O historiador da arte Giulio Carlo Argan, ao comentar a torre, chama atenção para sua única finalidade, que seria "dar visualidade e magnitude aos elementos de sua estrutura". Para ele, a "inegável função representativa" da torre "se cumpre na representação de sua funcionalidade técnica." A torre funcionaria como um "simbólico farol",

um elemento macroscópico de decoração urbana, que prevalece decididamente sobre os velhos símbolos (...); um monumento cuja singularidade é não ter nada de 'monumental', pois não comemora nem celebra um passado, não exprime princípios de autoridade nem dá expressão visual a ideologias, contudo glorifica o presente e anuncia o futuro. ${ }^{228}$

${ }^{227}$ LEVY, Ruth Nina Vieira Ferreira. Entre palácios e pavilhões: a arquiterura efêmera da Exposição Nacional de 1908. Dissertação (Mestrado em História da Arte). Universidade Federal do Rio de Janeiro, Centro de Letras e Artes, 1998, p. 90.

${ }^{228}$ ARGAN, Giulio Carlo. Arte moderna. São Paulo: Companhia das Letras, 2010, p. 85. 
Nossa Porta Monumental, bem mais modesta, media cerca de 25 metros de altura por 30 de largura (figura 69). ${ }^{229}$ Ainda assim, a construção fazia qualquer pessoa que por ela passasse parecer minúscula. É a primeira demonstração da grandiosidade do evento, local por onde os ingressantes experimentavam a primeira de muitas transformações que a arquitetura da Exposição sugere e promove, relativizando o tamanho e valor de seus corpos.

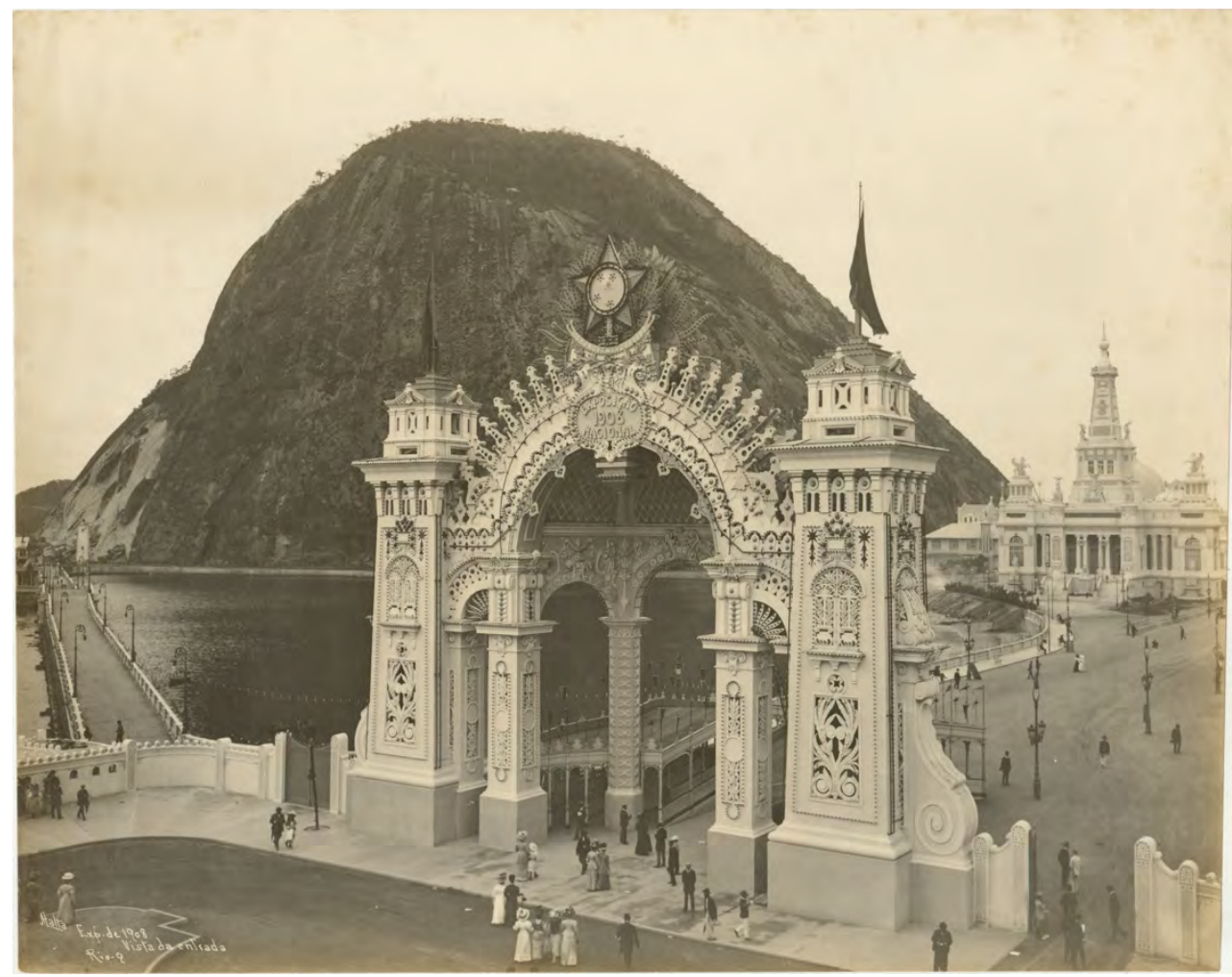

Figura 68 - Vista da entrada. Fotografia de Augusto Malta. Acervo Museu da República, Instituto Brasileiro de Museus - Ibram, do Ministério da Cidadania. Coleção Família Passos.

Diferente da torre francesa, sua estrutura está oculta sob a decoração em estilo art nouveau. De qualquer modo, a função representativa de que fala Argan também aparece neste portal, que funciona como peça cenográfica, já que a edificação funciona como um símbolo da grandiosidade de um presente. Ela é monumental, não só no sentido de monumento à República, mas também no sentido de uma dimensão extraordinária, que fala da grandeza do evento e, por extensão, do país.

Para entrar de fato no recinto, os visitantes passavam por outra construção (ligada à primeira, mas distintamente mais baixa e menos ornamentada), dividindo-se por uma curiosa série de caminhos estreitos. O Guia official assim os descreve:

${ }^{229}$ GUIA official da Exposição Nacional de 1908. Rio de Janeiro: Tavaresa Oliveira, 1908, p. 97. 
São em planos inclinados alternados, descendo um dos caminhos um metro, para subir depois até a saida, emquanto o caminho immediato sobe outro metro para descer do outro lado; de modo que o que desce tem dois metros de elevação no ponto de cobertura, superior á estatura media de um homem. Ao meio do caminho, isto é, nos pontos mais baixos dos que descem e mais altos dos que sobem, estão collocados registradores mecânicos, como os que são empregados nas pontes das barcas da Cantareira, para marcar o número de entradas. $^{230}$

Mesmo sendo um pouco difícil de entender exatamente como funcionava tal sistema, vale a pena deter-nos no modo como a arquitetura da Exposição tratava os corpos de seus visitantes. Pela descrição do Guia official, eram dez caminhos cobertos, de menos de um metro de largura e vinte de extensão, separados por corrimãos. Como explica Levy, "as roletas das galerias inferiores ficavam debaixo dos passadiços das galerias superiores no ponto de maior diferença de nível e as destas por cima das galerias inferiores". Os organizadores do evento justificaram o mecanismo por seu "ótimo resultado, evitando todas as causas de atropelamento". ${ }^{231}$ Ao que tudo indica, a diferença de altura entre as sendas teria então principalmente três propósitos: abrigar o sistema de catracas, economizar espaço e ordenar a multidão. O que na cidade é multidão caótica, passa por uma organização, uma racionalização. A entrada marca corporalmente uma diferença entre mundo exterior (a cidade) e mundo interior (o recinto da Exposição).

\footnotetext{
${ }^{230}$ GUIA official da Exposição Nacional de 1908. Rio de Janeiro: Tavaresa Oliveira, 1908, p. 103.

${ }^{231}$ LEVY, Ruth Nina Vieira Ferreira. Entre palácios e pavilhões: a arquiterura efêmera da Exposição Nacional de 1908. Dissertação (Mestrado em História da Arte). Universidade Federal do Rio de Janeiro, Centro de Letras e Artes, 1998, p. 88.
} 


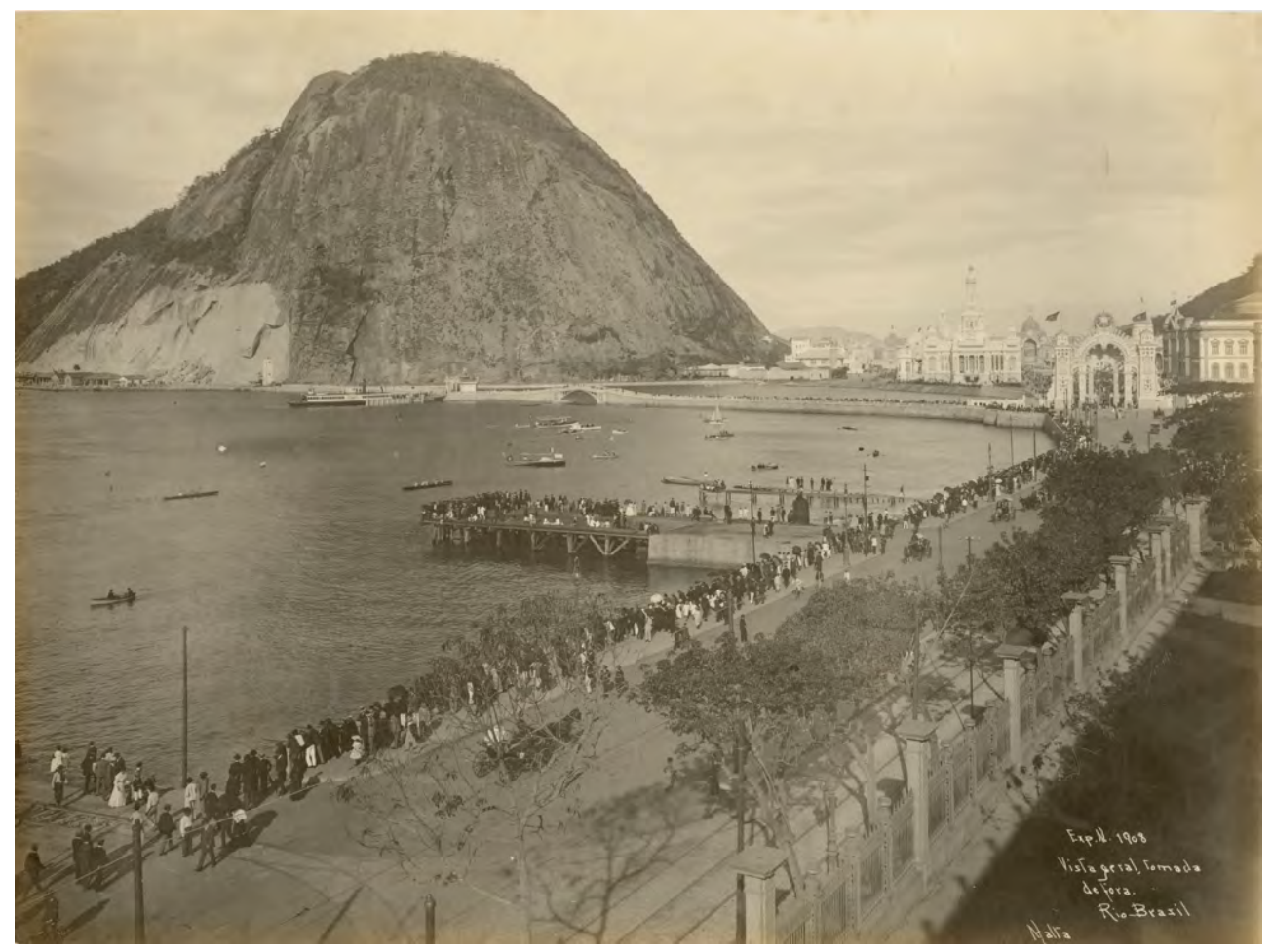

Figura 9 - Vista geral, tomada de fora. Fotografia de Augusto Malta. Acervo Museu da República, Instituto Brasileiro de Museus - Ibram, do Ministério da Cidadania. Coleção Família Passos.

Mas não é só isso. As diferentes inclinações dos caminhos, apesar de não serem muito íngremes, provavelmente serviam como uma pequena atração. Ao ingressar no sistema de entrada, o visitante talvez perdesse um pouco o controle sobre o próprio corpo ao ser levado a enfrentar tais aclives e declives (figura 71). Não é difícil imaginar que alguns, aproveitando o embalo proporcionado pelas rampas, ingressassem na Exposição com uma velocidade maior do que costumavam caminhar. Em resumo: ao comparar-se à grandiosidade da porta, os visitantes passavam por uma espécie de compressão; ao penetrar pelos caminhos estreitos, esses corpos eram submetidos a uma racionalização; e, ao ser obrigadas a subir e descer as rampas de acesso, as pessoas já experimentavam uma certa excitação sensorial. Esse estímulo sensório já os preparava para outras atrações que estavam por vir, principalmente na área de divertimentos da Exposição. Voltaremos a este ponto quando chegarmos lá. 


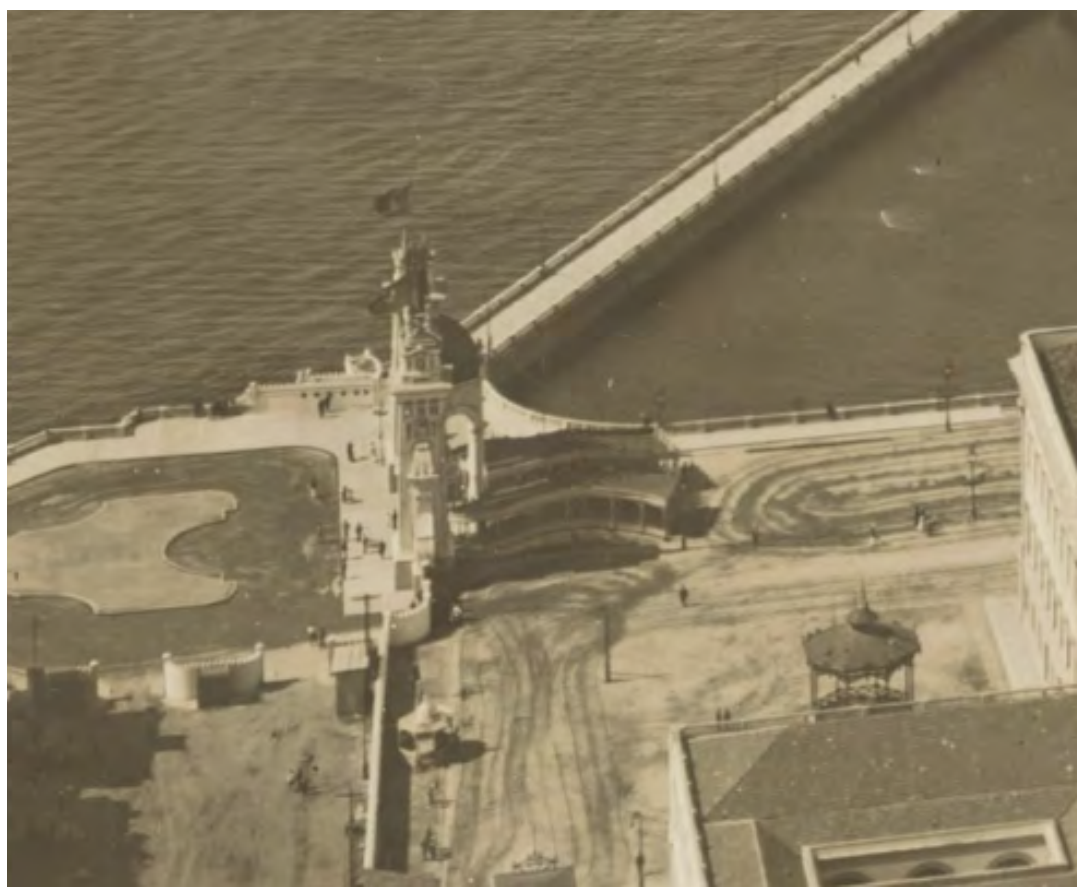

Figura 10 - Exp. de 1908 (detalhe do sistema de entrada). Fotografia de Augusto Malta. Acervo Museu da República, Instituto Brasileiro de Museus - Ibram, do Ministério da Cidadania. Coleção Família Passos.

Ao desembocar no espaço interno, o visitante encontrava-se na Avenida dos Estados, eixo central da Exposição. A larga via terminava no Palácio da Indústria, edifício que abrigara a antiga Escola Militar e que havia sido reformado com a inclusão de uma enorme fonte, que marcava o ponto final do trajeto, denominada Chateau d'eau, "castelo de água" (figura 72). Por meio de um "engenhoso sistema de bombas", a água podia cair perenemente, o que daria mais valor à obra segundo o Guia official da Exposição. Mas os jogos de água não eram "constantes, para que não per[dessem] o encanto pela vulgaridade". ${ }^{232}$ Os efeitos de água e luz compunham o ponto culminante da Exposição, o que replicava a estrutura da Exposição de 1889 de Paris, onde, na extremidade oposta à Torre Eiffel, ficava o Chateau d'eau original, no centro do pavilhão mais importante daquele evento, o Palácio da Eletricidade. Ambas fontes são espetacularizações da engenharia moderna.

${ }^{232}$ GUIA official da Exposição Nacional de 1908. Rio de Janeiro: Tavaresa Oliveira, 1908, 201. 


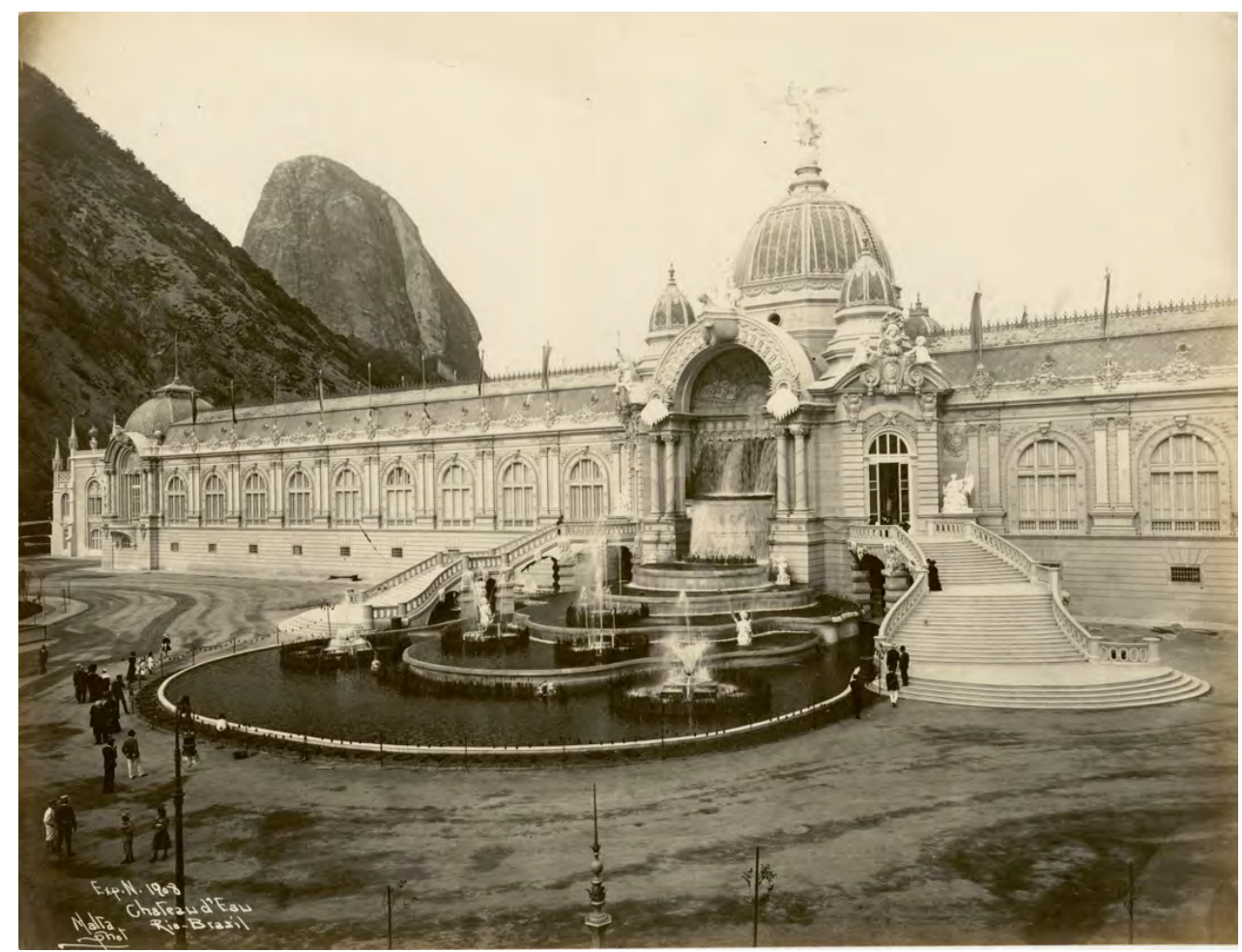

Figura 11 - Chateau d'Eau, Malta Phot. Acervo MHN.

Segundo Ruth Levy, era comum que os pavilhões “da Indústria” nas grandes exposições tivessem "a preocupação de refletir os avanços tecnológicos através de estruturas ousadas". ${ }^{233}$ Já as fontes de água, "com seus famosos repuxos, sempre tiveram papel de destaque nos recintos de exposição. Exploradas à noite, com iluminação especial, foram sempre atrativos neste tipo de cenário."234

No filme Pan-American Exposition by night (Edison, 1901), vemos um panorama da exposição realizada naquele ano em Buffalo, Nova York. A primeira parte mostra seus edifícios à luz do dia. Quando a câmera enquadra a Torre Elétrica, a principal construção daquele evento, a imagem escurece e a tomada panorâmica segue mostrando a exposição, agora em vista noturna. O que vemos dos edifícios, então, são suas linhas, marcadas por inúmeras lâmpadas elétricas. Na mudança do dia para a noite, o filme celebra um virtuosismo tanto arquitetônico quanto elétrico - e a capacidade que o cinema tem de evidenciá-los.

Outros filmes do primeiro cinema exploraram os efeitos da iluminação elétrica noturna de cidades, exposições e parques de diversão, como Coney Island at night

\footnotetext{
${ }^{233}$ LEVY, Ruth Nina Vieira Ferreira. Entre palácios e pavilhões: a arquiterura efêmera da Exposição Nacional de 1908. Dissertação (Mestrado em História da Arte). Universidade Federal do Rio de Janeiro, Centro de Letras e Artes, 1998, p. 103.

${ }^{234}$ Idem, p. 103-104.
} 
(Edison, 1905). Neste exemplo, vemos duas das maiores atrações do complexo de parques da península de Nova York, Dreamland e Luna Park, em lentas panorâmicas noturnas. As imagens, que chegam a formar composições abstratas de luz no fundo preto, salientam o caráter feérico da iluminação. Na exposição carioca de 1908, as lâmpadas elétricas também se estendiam por todos os caminhos, subindo as colunas dos pavilhões e fazendo reluzir seus símbolos de progresso (figura 73). E, quase todas as noites, havia queima de fogos de artifício no interior do recinto, enfatizando ainda mais a simbologia das luzes. É provável que o filme Sô Lotero e nhá Ofrasia... tivesse cenas noturnas, mostrando tanto a atração que eram as luzes da Exposição, como as reações de nossas personagens.

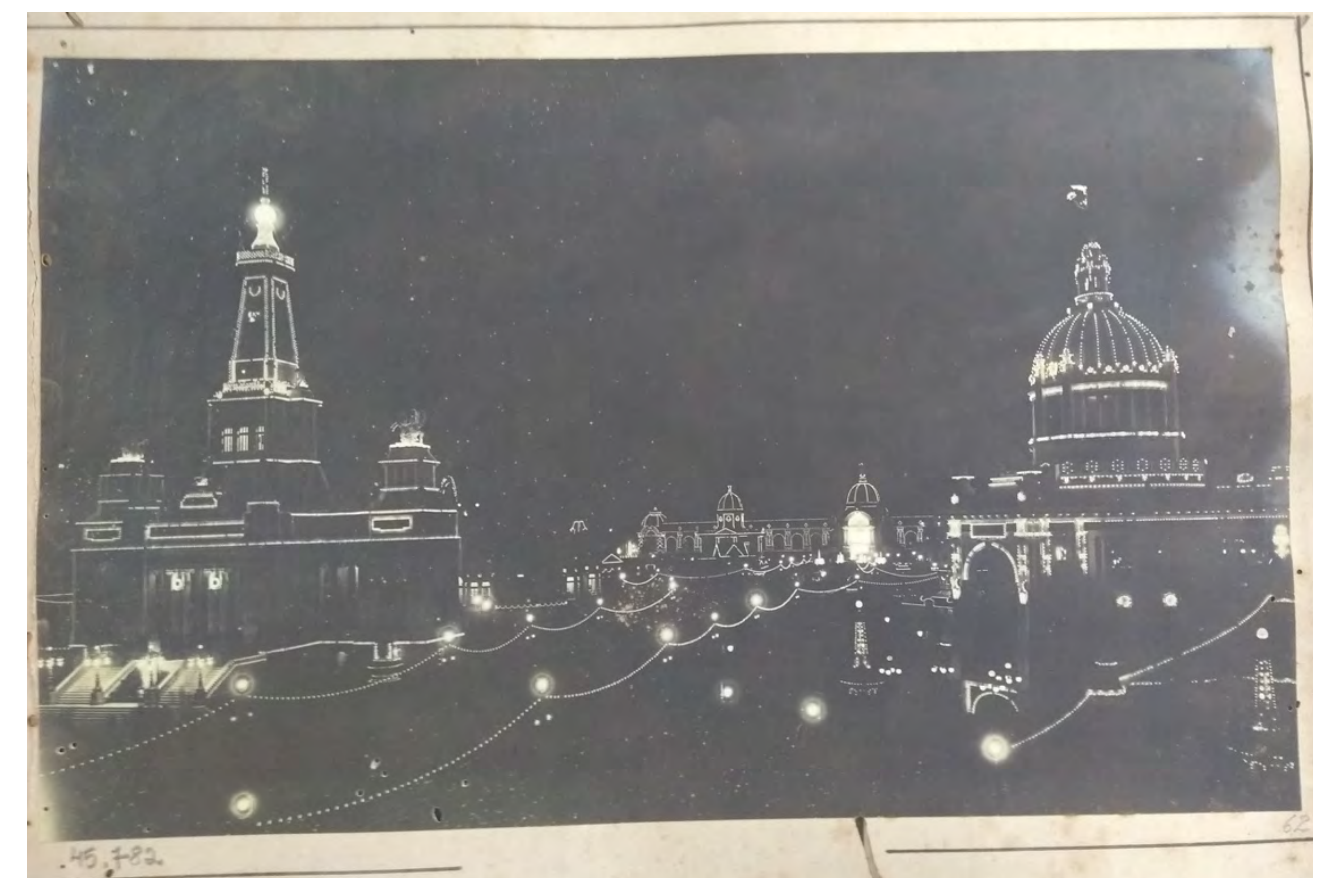

Figura 12 - Vista noturna da Exposição Nacional de 1908, com o Chateau d'eau ao fundo. Augusto Malta. Acervo MHN.

É no mesmo complexo norte-americano que se passa Rube e Mandy em Coney Island (Rube and Mandy at Coney Island, Edison, 1903), já citado por nós, exemplo paradigmático do filme de caipira em parque de diversões. $O$ filme mostra a visita de um casal de jovens roceiros a diferentes atrações de Coney Island. Vemos seus corpos serem derrubados por vacas, serem puxados por funcionários que os chamam a entrar em novas brincadeiras e serem esmagados por outros visitantes, por exemplo, num escorregador. Lauren Rabinovitz, ao tratar de parques de diversão, lembra que esses espaços eram justamente "lugares particularmente aptos a demonstrar a comédia do corpo humano em movimento na medida em que era rodopiado, balançado e virado de cabeça para baixo 
nas atrações mecânicas." 235 Esses parques são espaços onde, por excelência, o corpo experimenta sensações extremas: quedas, brusca aceleração, sustos, deslumbramento. Fora de lá, essas sensações estariam quase sempre ligadas a um perigo de morte, seja no atropelamento por automóvel, no pisotear da multidão ou na queda de um arranha-céu.

A tomada panorâmica, recurso comum aos filmes de viagem, aparece em Rube $e$ Mandy... ${ }^{236}$ na busca por compor uma vista ampla dos divertimentos do parque. Em um dos planos quase não se vê os protagonistas, tão minúsculos que estão, num cantinho do quadro. A arquitetura espetacular dos parques de diversão - e das grandes exposições - é propícia para as tomadas à distância. Como nas fotografias que ilustram esta seção do capítulo, é provável que parte dos planos de Sô Lotero e nhá Ofrasia... fosse aberta, panorâmica, de modo a dar ao espectador uma visão geral do espaço, enfatizando a grandiosidade de seus edifícios e, por consequência, a pequenez dos corpos das personagens e dos outros visitantes em cena.

Com frequência, vemos Rube e Mandy apontando com curiosidade para os edifícios do parque, gesticulando indignados e acenando animados com seus lencinhos em mãos. Com uma performance de gestos exagerados, os atores de vaudevile que os interpretavam "tornam-se também uma estranha novidade para os frequentadores do parque", como aponta Flávia Cesarino Costa. ${ }^{237}$ Neste ponto, podemos imaginar que, assim como no filme norte-americano, a presença dos atores que interpretaram Lotero e Ofrasia também causaria espanto, curiosidade ou constrangimento nos visitantes da Exposição Nacional que estivessem presentes nos dias de filmagem. Neste caso, poderíamos dizer que os transeuntes, atuando (mesmo que eventualmente a contragosto) como figurantes do filme, fariam o papel da plateia ausente em Tio Josh na sessão de cinema (Uncle Josh at the moving-picture show, Edison, 1902), discutido anteriormente. Entre nós (espectadores) e eles (caipiras), estaria este terceiro elemento.

Seguindo a discussão teórica e historiográfica sobre o mito de fundação do cinema, apresentada no início do capítulo, podemos nos perguntar como estes terceiros participariam daquela operação de distinção implicada na espectatorialidade dos filmes de caipira. Nas fotografias da Exposição, a multidão parece bastante contida. As mulheres

\footnotetext{
${ }^{235}$ RABINOVITZ, Lauren. Amusement parks. ABEL, Richard (Ed.). Encyclopedia of Early Cinema. New York: Routledge, 2005, p. 22.

${ }^{236}$ MUSSER, Charles. The emergence of cinema: the american screen to 1907. Berkeley / Los Angeles: University of California Press, 1990, p. 349.

${ }^{237}$ COSTA, Flávia Cesarino. O primeiro cinema: espetáculo, narração, domesticação. São Paulo: Azougue Editorial, 2005, p. 159.
} 
e meninas quase sempre usam chapéus fartamente decorados, vestidos de cores claras, seguram sombrinhas e leques; os homens aparecem normalmente de terno, chapéu e bengala. Não são os trajes mais adequados para atividades físicas intensas, ainda mais considerando-se o calor que provavelmente fazia. Rube e Mandy, por exemplo, seguem o mesmo figurino, mas diferem nos acessórios: eles não carregam nada consigo, além de chapéus de palha, mais leves - o que permite maior liberdade de movimento, necessária para suas traquinadas, como montar em camelos ou equilibrar-se sobre cordas. No caso dos protagonistas do filme brasileiro perdido, pela caracterização que extraímos do folhetim em que antes apareceram, suas roupas já seriam uma piada em si. Como vimos, só isso já seria suficiente para fazê-los destoar na multidão. No que diz respeito aos gestos, até onde pudemos observar em fotografias da Exposição, os homens estão sempre com as mãos baixas, apoiadas em suas bengalas ou segurando cigarros; as mulheres, além de levar sombrinhas e leques, também dão as mãos para outras mulheres ou crianças. Se os atores trabalhassem com uma gesticulação hiperbólica, interpretação típica dos filmes de caipira estrangeiros, certamente chamariam a atenção dos passantes. Um casal de roupas desajustadas e gestos exagerados destoaria. Sendo o casal alvo das lentes de uma câmera cinematográfica, não seria estranho que os passantes se posicionassem nas cenas, de modo a garantir uma participação no filme.

Rube e Mandy... termina com um "quadro inserido",238 do casal em fundo escuro, finalmente isolando-o da profusa paisagem do parque e mostrando-o mais de perto. Estes "quadros de apresentação de personagens" 239 eram comuns no primeiro cinema e exemplos conhecidos são o close do bandido em $O$ grande roubo do trem (The great train robbery, Edison, 1903) e a composição que apresenta o bebê e o cachorro que irá salválo em Salvo pelo Rover (Rescued by Rover, Hepworth, 1905). Para Costa, tal plano em Rube e Mandy... tem a única função de mostrar os caipiras de perto. Mas, como ela mesma descreve, o plano mostra os caipiras "lambuzando-se ao devorar cachorros-quentes". 240 Ou seja, o plano os mostra fazendo uma ação relevante, uma ação que os descreve. O corpo dos protagonistas, que foi chacoalhado, lançado, diminuído etc., ao longo de todo o filme, é agora mostrado mais ou menos estático. Ainda assim, é no corpo que se materializa sua rusticidade e seu desejo incontrolável por "devorar" o mundo urbano, "lambuzando-se" com ele. Se houvesse um plano de apresentação das personagens em

${ }^{238}$ COSTA, Flávia Cesarino. O primeiro cinema: espetáculo, narração, domesticação. São Paulo: Azougue Editorial, 2005, p. 159.

${ }^{239}$ Idem, p. 185.

${ }^{240}$ Idem, p. 159. Grifos nossos. 
Sô Lotero e nhá Ofrasia, podemos imaginar duas possibilidades: os dois vestindose/despindo-se para câmera ou eles exibindo para a câmera os tais produtos que o título do filme sugere que eles teriam levado para a Exposição. Na primeira opção, talvez os víssemos sofrer para fechar botões, jogar peças de roupa no chão e enfeitar-se com abundantes acessórios. Na segunda opção, veríamos possivelmente as batatas plantadas e colhidas por eles e objetos manufaturados. De qualquer maneira, provavelmente seriam gestos que enfatizassem uma rusticidade "tosca".

Rube e Mandy... é um exemplo da "composição ambígua de atrações e relato", ${ }^{241}$ comum no chamado período de integração narrativa do primeiro cinema. ${ }^{242}$ Costa sugere que a "precária" linearidade narrativa é mantida apenas pela presença do casal de caipiras, e os planos poderiam ser embaralhados sem prejuízo. ${ }^{243}$ Poderíamos provavelmente dizer o mesmo de nosso filme brasileiro perdido. Aqui, no entanto, optamos por seguir o trajeto que nos pareceu mais linear, do portão de entrada seguindo em direção à apoteose da Exposição (o Chateau d'eau), a partir das sugestões identificadas na documentação ligada à Exposição Nacional.

Sigamos, então, nosso trajeto. O primeiro edifício que o visitante vê depois de passar pelo portão, à direita, é o Palácio da Exposição, também chamado de Palácio dos Estados. A construção, um dos maiores prédios públicos da época, tinha oitenta metros de largura por vinte e dois de altura. Nele, todos os estados brasileiros tinham espaço para expor seus produtos considerados mais típicos ou avançados. O primeiro pavilhão era, portanto, uma espécie de primeiro tour pelo Brasil, replicando a lógica da própria Exposição, que pretendia condensar toda a produção do país numa espécie de ilha encantada, onde seria possível percorrer milhares de quilômetros em poucas horas.

\footnotetext{
${ }^{241}$ COSTA, Flávia Cesarino. O primeiro cinema: espetáculo, narração, domesticação. São Paulo: Azougue Editorial, 2005, p. 158.

${ }^{242}$ Que teria durado de 1899 a 1903 . MUSSER, Charles. Rethinking early cinema: cinema of attractions and narrativity. In: STRAUVEN, Wanda (Ed.). The cinema of attractions reloaded. Amsterdam: Amsterdam University Press, 2006, pp. 389-412.

${ }^{243}$ COSTA, Flávia Cesarino. O primeiro cinema: espetáculo, narração, domesticação. São Paulo: Azougue Editorial, 2005, p. 159.
} 


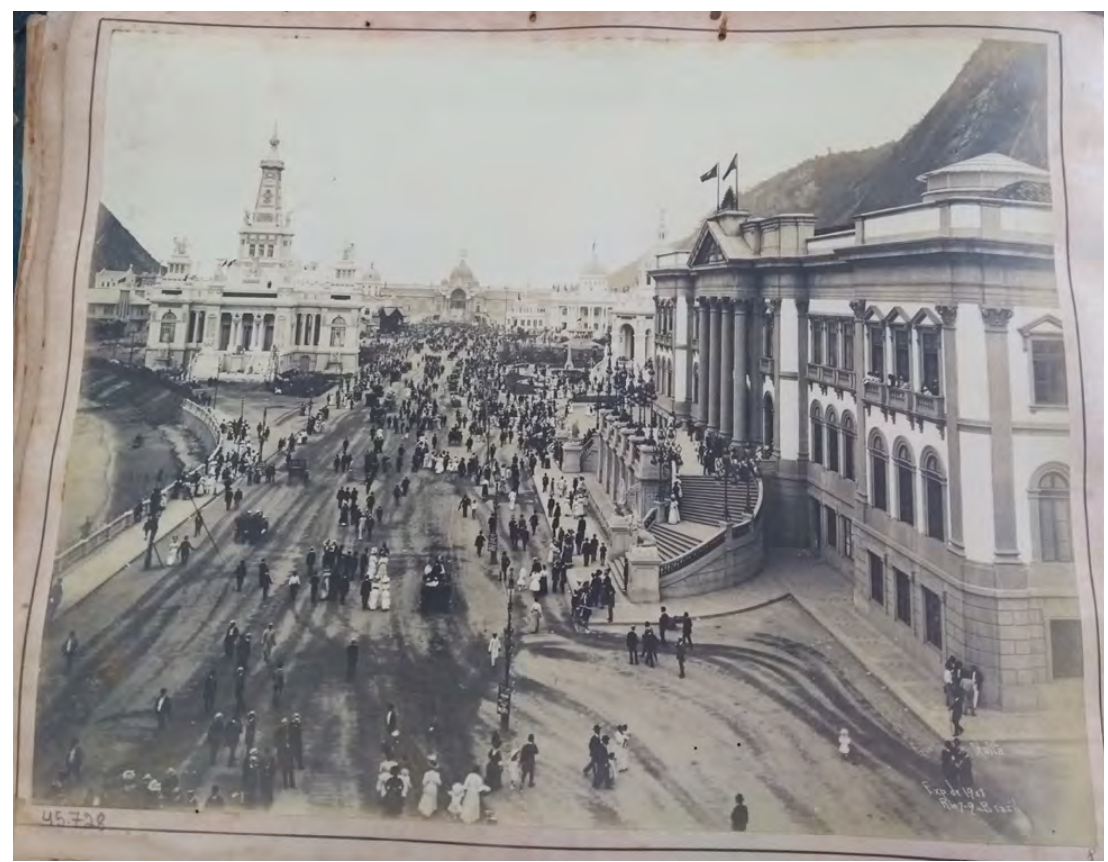

Figura 13 - Vista da Avenida dos Estados, com o Palácio da Exposição à direita, o Pavilhão de Minas Gerais à esquerda, e o Palácio da Indústria ao fundo. Augusto Malta. Acervo MHN.

A Exposição Nacional de 1908 ocupou um terreno de 16.000 metros quadrados, ${ }^{244}$ que ficava entre o morro da Urca, o da Babilônia, a praia Vermelha e a praia da Saudade (posteriormente aterrada, na década de 1930), onde ficava o molhe da Urca. Além das praias e dos morros, a vista conjugava a própria cidade do Rio de Janeiro, ao longe, "pompeando no casario elegante e nos jardins caprichosos da Avenida Beira-Mar" dentro dos pavilhões, eram encontrados objetos os mais diversos, como obras de arte, produtos da indústria brasileira e novas invenções. A Exposição, de modo análogo aos simuladores cinematográficos, analisados no capítulo anterior, buscava fazer o visitante sentir-se imerso - aqui, num Brasil cosmopolita, por meio da reprodução de uma versão idealizada e totalizadora do país. Ao longo da avenida principal, que tinha 570 metros de extensão, foram construídos pavilhões específicos para alguns estados brasileiros. Primeiro via-se, à direita, o da Bahia, em "estilo Renascença Italiana, do século XVI" como descreve o Guia. O edifício tinha trinta e oito metros de altura e foi demolido logo depois da Exposição. ${ }^{246}$ Depois, à esquerda, ficava o de Minas Gerais, “exageradamente decorado, com grande estatuária, fontes, escadaria, e o torreão altíssimo, que dobrava sua

\footnotetext{
${ }^{244}$ LEMBRANÇA da Exposição Nacional do Rio de Janeiro: com vistas da exposição, da capital federal e breves descripções. São Paulo: Temistocle Severi, 1908, p. 10.

${ }^{245}$ BILAC, Olavo apud MARIANI, Luiza Helena. Bilac, João do Rio e a Exposição Nacional de 1908. In: PEREIRA, Margareth da Silva (Org.). 1908: Um Brasil em Exposição. São Paulo: Casa 12, 2011, p. 87.

${ }^{246}$ LEVY, Ruth Nina Vieira Ferreira. Entre palácios e pavilhões: a arquiterura efêmera da Exposição Nacional de 1908. Dissertação (Mestrado em História da Arte). Universidade Federal do Rio de Janeiro, Centro de Letras e Artes, 1998, 112 - 113.
} 
altura". ${ }^{247}$ Logo atrás dele ficava o de São Paulo, "o maior dos mandados construir pelos Estados", com 1.500 metros quadrados de área, ${ }^{248}$ projetado por Ramos de Azevedo. ${ }^{249}$ O edifício foi vencedor da votação do público no Concurso de Pavilhões. Seguindo pela avenida, à direita ficava o Pavilhão do Distrito Federal.

Por fim, logo antes do Palácio da Indústria, havia um pequeno chalé de madeira representando Santa Catarina, que destoava dos luxuosos pavilhões dos outros estados. Segundo Levy,

exemplos de "casas típicas” foram comuns nas Exposições Universais. Desde cedo, mostrar a forma de habitar dos outros povos, em grupos de 'pitorescas construções', foi uma curiosidade oferecida no cenário das exposições. (...) a tradição construtiva das áreas rurais, reafirmando o nacionalismo de cada país, se tomaram atrativos 'pitorescos' no meio urbano das exposições. ${ }^{250}$

É por contrastar com o cenário predominantemente urbano das exposições que essas casinhas tinham valor. Olavo Bilac, por exemplo, defendeu a Casa de Santa Catarina, como era chamada, como merecedora do prêmio do tal Concurso dos Pavilhões:

\begin{abstract}
Até o pequeno chalet de Santa Catarina, tão gracioso na sua simplicidade, merece o voto de um homem de educação artística: a sua rústica beleza, destituída de toda pretensão, não faz má figura ao lado dos palácios. Santa Catarina pode mesmo dizer com orgulho aos outros Estados: "vocês tem casas muito mais suntuosas do que a minha; mas o ferro, o cimento, o vidro desses palácios vieram do estrangeiro; ao passo que, em minha casa modesta, tudo é meu, tudo saiu do meu próprio seio, tudo é filho da minha pouca fortuna e do meu honroso trabalho!",251
\end{abstract}

Neste sentido, cabe arriscar uma analogia entre a casa rústica e nossos caipiras. O chalé, feito com material originário daquele estado, oferecia um contraste às outras construções, inspiradas em diferentes estilos arquitetônicos europeus, de caráter grandioso e moderno. Por um lado, a presença do chalé rústico evidencia a suntuosidade dos palácios; por outro, faz questionar certa artificialidade das outras construções, de estilo estranho ao nacional. De modo semelhante, a presença dos caipiras no espaço da Exposição pode ter representado um contraste comportamental, que tanto apontaria para a "elegância" dos outros visitantes, quanto para a artificialidade de gestos tão comedidos. Uma propaganda

\footnotetext{
${ }^{247}$ LEVY, Ruth Nina Vieira Ferreira. Entre palácios e pavilhões: a arquiterura efêmera da Exposição Nacional de 1908. Dissertação (Mestrado em História da Arte). Universidade Federal do Rio de Janeiro, Centro de Letras e Artes, 1998, 118.

${ }^{248}$ Idem, 109.

${ }^{249}$ GUIA official da Exposição Nacional de 1908. Rio de Janeiro: Tavaresa Oliveira, 1908, 221.

${ }^{250}$ LEVY, Ruth Nina Vieira Ferreira. Op. cit., 120.

${ }^{251}$ BILAC, Olavo apud LEVY, Op. cit., p. 121.
} 
da sala exibidora descreveu o filme Sô Lotero e nhá Ofrasia... como uma "grandiosa fita, crítica nacional e de actualidade" ${ }^{252}$. É possível que tal crítica tenha a ver justamente com uma operação de contraposição entre os visitantes, que agem de modo contido, “civilizado" - portanto não natural, afetado -, e o casal de caipiras, que reagem a tudo de modo histriônico, "não civilizado" - portanto genuíno, espontâneo.

Além da Avenida dos Estados, a Exposição contava com algumas veredas, praças ajardinadas e caminhos, onde ficavam outras construções, como o Pavilhão da Viatura; um Posto da Assistência Municipal; o Pavilhão do Corpo de Bombeiros; o Pavilhão da Fábrica Bangu, uma empresa têxtil; o pequeno Pavilhão da Imprensa, onde era produzido o Jornal da Exposição, editado por Olavo Bilac; a estufa e jardins da exposição do Jardim Botânico; o Palácio Português, com seu anexo dedicado às "Bellas Artes", em estilo manuelino, oferecido pelo governo do Brasil a Portugal. Havia também pequenos coretos musicais espalhados pelo espaço, assim como restaurantes, banheiros e quiosques para a venda de flores, cigarros, charutos e jornais.

Em um dos edifícios, o Palácio das Artes Liberais, além de obras de arte oriundas de diversas partes do país, estavam expostos mapas e maquetes dos prédios da própria Exposição. ${ }^{253} \mathrm{Se}$, desde a entrada pela Porta Monumental, o corpo do visitante parecia diminuto em comparação com a grandiosidade das construções, as maquetes sugerem uma nova relação corporal, na qual o visitante parece muito maior que antes. A maquete funciona como imagem da miniaturização que a própria Exposição faz do país. Metaforicamente, o visitante é algo como um gigante, que percorre o Brasil inteiro em uma caminhada.

Não à toa, alguns estados "distribuíam uma profusão de representações visuais aos visitantes de seus stands". Ao inaugurar seu pavilhão, o Estado da Bahia “disponibilizou 50.000 cartões postais com 40 vistas de cidades, retratos de homens ilustres do Estado, memórias e mapas de municípios baianos". ${ }^{254}$ Além disso, uma parcela do público da Exposição foi presenteada com álbuns fotográficos, os chamados Álbuns dos Estados. Como explica Maria Eliza Borges, “como um atlas que classifica, ordena e constrói representações miniaturizadas de um território, os álbuns dos estados narravam a saga das regiões retratadas. (...) as fotografias, neles dispostas, dialogavam com a geografia enquanto documentavam as partes consideradas mais relevantes da economia

${ }^{252}$ Jornal do Brasil, 30/08/1908, p. 20.

${ }^{253}$ GUIA official da Exposição Nacional de 1908. Rio de Janeiro: Tavaresa Oliveira, 1908, p. 157.

254 BORGES, Maria Eliza Linhares. A Exposição Nacional de 1908 e a produção da identidade nacional brasileira. In: Anais do Museu Histórico Nacional, vol. 40, 1998, p. 88. 
dos estados." ${ }^{255}$ Estas exposições eram justamente um "espetáculo idealizado para ser consumido visualmente pelos cidadãos das grandes cidades". ${ }^{256} \mathrm{O}$ turismo é uma forma de consumo. E o caipira na cidade representa um modo de ser turista.

Em 1851, Londres sediou o que ficou conhecida como a primeira exposição internacional da história, chamada de "The great exhibition of the works of industry of all nations", ou apenas "Crystal Palace Exhibition", apelido dado por conta do edifício construído especialmente para o evento. O palácio de vidro, todo estruturado em ferro, custou cerca de dois milhões de libras e estampou inúmeros cartões postais, moedas e outros produtos. Assim como as outras exposições que se seguiram, em diversos locais, o objetivo era que cada país exibisse tudo o que seu povo havia criado em termos de inovação. Segundo Tom Gunning, uma nova cultura visual surge com as exposições, caracterizada por

uma nova fé no poder do conhecimento visual; uma concepção de mundo como imagem consumível, apresentada por meio do colapso do espaço e do tempo; e um endereçamento visual agressivo pretendendo deslumbrar o espectador com um novo controle sobre o olhar. ${ }^{257}$

Caminhar por esses espaços era como fazer uma viagem de volta ao mundo, na qual arte e indústria se uniam para seu deleite visual.

\section{Labaredas espetaculares}

Depois de percorrer toda a avenida principal - da entrada até a enorme fonte de água instalada no Palácio da Indústria - e de passar por outras atrações nas ruazinhas adjacentes, nosso passeio deve terminar. Afinal, o Chateau d'eau é o ápice da Exposição. Mas não é o que acontece. Subindo as escadarias que margeiam a fonte e, em seguida, atravessando o prédio, chegamos a um enorme terreno, até então oculto dos visitantes.

\footnotetext{
${ }^{255}$ BORGES, Maria Eliza Linhares. A Exposição Nacional de 1908 e a produção da identidade nacional brasileira. In: Anais do Museu Histórico Nacional, vol. 40, 1998, p. 88.

${ }^{256}$ MORETTIN, Eduardo Victorio. As exposições universais e o cinema: história e cultura. Revista Brasileira de História. São Paulo, v. 31, no. 61, 2011, p. 232.

${ }^{257}$ GUNNING, Tom. The world as object lesson: cinema audiences, visual culture, and the St. Louis World's Fair, 1904, Film History 6, no. 4, 1994, p. 440-441. Grifo nosso.
} 
Era a área destinada a diversões, dirigida por Paschoal Segreto, proprietário de diversas casas de espetáculos bem-sucedidas do Rio de Janeiro e de São Paulo, à época. ${ }^{258}$

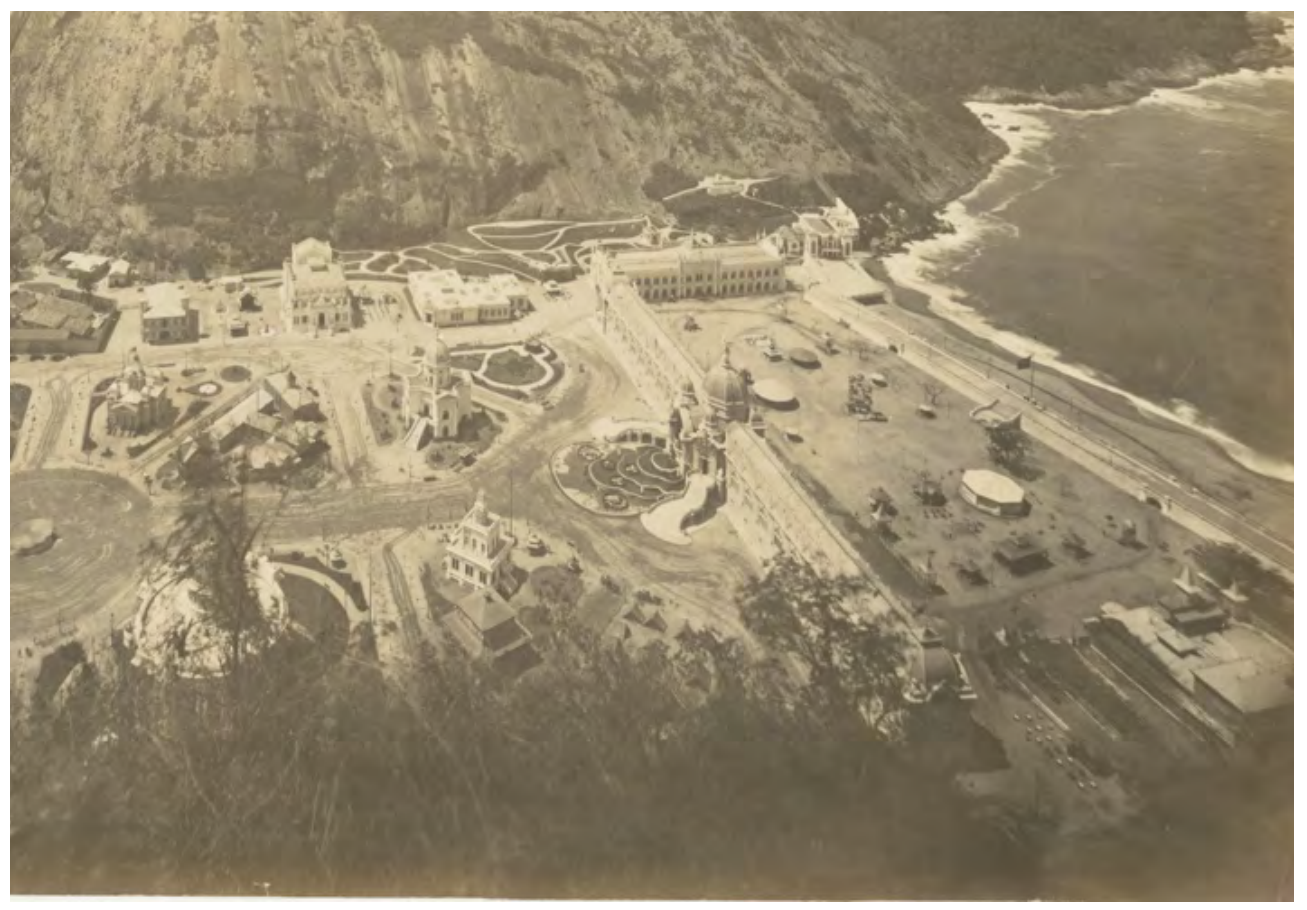

Figura 14 - Vista panorâmica da Exposição, na qual se vê a área dedicada à diversão, à direita (detalhe). Fotografia de Augusto Malta. Acervo Museu da República, Instituto Brasileiro de Museus - Ibram, do Ministério da Cidadania. Coleção Família Passos.

Segundo Tom Gunning, em exposições em que não havia áreas exclusivas ao divertimentos comerciais, no final do século XIX, formaram-se complexos de atrações não regulamentadas nas proximidades, fora do controle dos organizadores daqueles eventos. Isso teria levado, ao longo dos anos, à inclusão de setores internos dedicados ao entretenimento. O autor, ao analisar a Exposição Mundial de St. Louis, realizada em 1904, nos Estados Unidos, fala da importância dessas áreas de lazer:

O espetáculo visual permeia a Exposição Mundial, mas encontra sua mais pura demonstração no que era conhecido como Seção de Concessões, as áreas de entretenimento comercial que progressivamente invadiram as exposições norte-americanas, agigantando-se como sua sombra escura ou gêmeo maligno. $^{259}$

\footnotetext{
${ }^{258}$ Imigrante italiano, Segreto foi também vendedor ambulante de bilhetes de loteria, tendo sido preso diversas vezes pela exploração de jogos ilegais. Cf. SOUZA, José Inácio de Melo. Imagens do passado: São Paulo e Rio de Janeiro nos primórdios do cinema. São Paulo: Editora Senac, 2004, p. 119-129.

${ }^{259}$ GUNNING, Tom. The world as object lesson: cinema audiences, visual culture, and the St. Louis World's Fair, 1904, Film History 6, no. 4, 1994, p. 430.
} 
Na Exposição Nacional de 1908, a localização do complexo de diversões é isolada do resto, compondo uma espécie de poscênio da cenografia oficial, representada por sua máxima expressão, o Chateau d'eau. As diversões ficam atrás, depois, da apoteose do percurso. Na área, que tem um formato retangular e nenhuma marcação que diferencie rua e calçada, as construções que abrigam as atrações são dispostas de modo fundamentalmente diferente da grandiosidade e ordenação que predominam no resto do recinto, que lembra a organização geométrica da "haussmannização" de Paris. ${ }^{260}$ Ali, o público podia desfrutar de um cinematógrafo, de um teatro de variedades e de um salão de patinação, além de "montahna (sic) russa, salões de prendas, pesca milagrosa, fio aereo, jogos de destreza, carroussel, palacio das illusões, photografia, dioramas, guignol, balões captivos, carroussel para creanças, bicyclettas, balanços higienicos, etc.". ${ }^{261}$ Além disso, havia mais uma sala de cinema e mais um teatro, fora da área dedicada exclusivamente ao entretenimento.

Todas essas atrações eram pagas à parte, custando de 500 a 1.500 réis por viagem, jogada ou sessão. Cada atração somava-se, então, ao preço de entrada na Exposição, que variava entre 500 e 1.000 réis, ${ }^{262}$ "sendo que no dia da inauguração, nas quintas-feiras, vésperas de feriado ou dia santo os bilhetes custavam $2 \$ 000 " .{ }^{263} \mathrm{O}$ custo da visita à Exposição não termina aí: se o visitante desejasse descansar durante o percurso, havia uma enorme quantidade de cadeiras, espalhadas pelo recinto, que custavam 200 réis por cada assento a ser ocupado, ou 500, "com direito a todo o dia podendo se assentar em qualquer d'ellas". ${ }^{264}$ Tudo isso fazia do passeio um luxo, ainda mais se contarmos outros gastos, como o transporte até lá e o consumo de comida e bebida. O horário de funcionamento da Exposição era das dez horas da manhã até a uma da madrugada. Como as salas de exposição de produtos funcionavam apenas das treze às vinte e uma, ${ }^{265}$ só podemos imaginar que, nas horas restantes, os visitantes se dedicassem a atividades como as sessões de teatro, música e cinema, os espetáculos noturnos de fogos de artifício e, claro, as atrações montadas por Segreto.

\footnotetext{
${ }^{260}$ Que já servira de modelo para as reformas urbanas de Pereira Passos (1902-1906). Segundo Maria Luiza Borges, "(...) avenidas de até 50 metros de largura seriam cortadas por ruas também largas e retilíneas, bem ao estilo do paradigma urbanista iniciado por Haussmann." (A Exposição Nacional de 1908 e a produção da identidade nacional brasileira. In: Anais do Museu Histórico Nacional, vol. 40, 1998, p. 84.)

${ }^{261}$ GUIA official da Exposição Nacional de 1908. Rio de Janeiro: Tavaresa Oliveira, 1908, p. 231.

${ }^{262}$ Idem, p. 83.

${ }^{263}$ A Exposição Nacional de 1908 e a produção da identidade nacional brasileira, p. 89.

${ }^{264}$ GUIA official da Exposição Nacional de 1908. Op. cit., p. 25.

${ }^{265}$ Idem, p. 32.
} 
E é na tabela de preços do Guia official, que podemos obter mais informações sobre as atrações da área de diversões. A patinação, por exemplo, dava direito a patins e a um professor, por duas horas. Havia também tiro ao alvo, um boneco japonês distribuidor de prêmios, um "diorama universal", "jogos de bengala", "pim-pam-pum" (este também com direito a prêmios) e "automaticos diversos". ${ }^{266}$ Mesmo sem saber exatamente do que se tratava cada brinquedo, podemos sugerir que a maioria tinha por função estimular fisicamente o público, seja por meio de ilusões ópticas, seja pela criação de simulação de experiências em ambientes controlados ou pela excitação corporal propriamente dita. Rabinovitz descreve os parques de diversão como uma "atmosfera de excitação visual e auditiva ou cinestesia, uma demonstração de novas tecnologias mecânicas". ${ }^{267}$ Nesse sentido, a brincadeira iniciada no sistema de entrada da Exposição era retomada neste espaço, agora de modo muito mais explícito.

$\mathrm{Na}$ sala de cinema empresariada por Segreto, o público podia ver filmes da empresa francesa Pathé Frères. Segundo Vicente de Paula Araújo, Segreto tentou ter exclusividade também no direito de filmagens no recinto, mas seu pedido foi negado pelo Supremo Tribunal. ${ }^{268}$ Ele fez alguns filmes na Exposição, mas outros produtores também o fizeram, como é o caso de Sô Lotero e nhá Ofrasia.... Na Filmografia Brasileira são listados outros doze filmes sobre o evento, dos quais citamos como exemplos: Inauguração da Exposição Nacional (Photo-Cinematographica Brasileira, 1908), Almoço aos conselheiros argentinos no Pavilhão Nacional de Agricultura (Empresa Paschoal Segreto, 1908) e O balão do Capitão Lippi (Empresa Paschoal Segreto). Com o título $O$ corso de carruagens na Exposição, há três entradas, uma produzida por Jácomo Rosário Staffa, outra por Segreto e outra por Labanca, Leal \& Cia, mesma produtora de nosso filme perdido. Nenhum desses filmes sobreviveu até nós.

Mas o "espetáculo" que mais nos interessa aqui, do qual o cinema de Segreto foi protagonista, é outro: no dia 20 de setembro, um domingo, a sala de cinema de seu complexo de diversões foi devastada por um incêndio. No mesmo dia, o Jornal da Exposição publicou uma nota de "ULTIMA HORA”, noticiando o acontecido.

Quando o Jornal da Exposição entrava no prelo, 3 e 35 da tarde, tivemos noticia de que lavrava incendio no Cinematographo e no Theatro de

\footnotetext{
${ }^{266}$ GUIA official da Exposição Nacional de 1908. Rio de Janeiro: Tavaresa Oliveira, 1908, p. 24-25.

${ }^{267}$ RABINOVITZ, Lauren. Amusement parks. ABEL, Richard (Ed.). Encyclopedia of Early Cinema. New York: Routledge, 2005, p. 22.

${ }^{268}$ ARAÚJO, Vicente de Paula. A Bela Época do Cinema Brasileiro. São Paulo: Editora Perspectiva, 1976, p. 263.
} 


\begin{abstract}
Variedades, pertencentes á Empreza Paschoal Segreto. Pelo que nos foi possivel saber, o fogo teve começo no Cinematographo, na occasião em que o operador funccionava. Em dez minutos, as chammas destruiram todo o edificio, e á hora em que escrevemos esta noticia o fogo, que lavra intensamente, alimentado pelo vento, ameaçava destruir o Theatro Variedades, esforçando-se os bombeiros para localizal-o na parede fronteira ao Cinematographo. Os bombeiros, apesar da falta d'agua, fazem prodigios para extinguir o fogo. $\mathrm{O}$ fogo de artificio, que deve ser queimado logo á noite e que estava perto, nada soffreu. ${ }^{269}$
\end{abstract}

Dois dados que aparecem no trecho merecem nossa atenção. Em primeiro lugar, é irônica a informação sobre a falta de água. Lembremos que, a alguns metros do cinematógrafo, do outro lado do Pavilhão da Indústria, ficava o Chateau d'eau. Segundo o Guia official, a enorme fonte de água consumiria "a metade, se não mais, do abastecimento do Rio de Janeiro", se não fosse o reservatório construído ali para abastecê-la. ${ }^{270}$ Não havia água para apagar um incêndio, mas a fonte decorativa continuava intacta. Depois, o outro detalhe que salta aos olhos é a proximidade entre a sala de cinema em chamas e os fogos de artifício. Se o fogo tivesse alcançado os artefatos de pirotecnia, o desastre teria sido muito mais grave. A matéria contava também que "junto ao Palacio das Industrias, na esplanada e no Bosque dos Amores estaciona[va] enorme multidão, que contempla[va] horrorisada o incendio".

O jornalzinho, que tinha distribuição gratuita no local, publicou inclusive uma nota de autoelogio pela rapidez com que havia espalhado a notícia.

\footnotetext{
O fogo declarou-se ás 3,35 da tarde e, ás 4 horas, a ultima pagina do Jornal entrava no prelo já com a noticia composta e emendada. Isto é, no pequeno espaço de 25 minutos, o nosso reporter tomou as suas notas no local do incendio, transmittiu-as ao redactor de serviço, que escreveu a noticia e a passou ao linotypista; pouco depois os revisores reenviavam-lhe a prova para emendar e o paquet seguia para a pagina. E ás 4 1 12 , o Jornal da Exposição era distribuido por todo o recinto, narrando o começo do incendio, que os bombeiros ainda extinguiam. ${ }^{271}$
}

Em poucos instantes, o fogo colocou o cinema abaixo e, também em apenas alguns minutos, o jornal fez correr a informação. Ao divulgar a notícia enquanto ela ainda acontecia, a folha certamente contribuiu para aumentar a massa de pessoas que assistia à cena.

269 GRANDE incendio. No cinematographo e no theatro da Empreza Segreto. Jornal da Exposição, 20/09/1908, p. 2.

${ }^{270}$ GUIA official da Exposição Nacional de 1908. Rio de Janeiro: Tavaresa Oliveira, 1908, p. 199.

${ }^{271}$ O INCENDIO de ontem. Jornal da Exposição, 21/09/1908, p. 1. 
O Correio da manhã, que divulgou o fato apenas no dia seguinte, ofereceu uma descrição mais detalhada do acontecido. Vale a pena reproduzir aqui alguns trechos mais longos:

\begin{abstract}
Apenas teria sido realizada uma sessão, eram para mais de tres horas da tarde quando a campainha do cinematographo avisou que o espectaculo ia pela segunda vezs (sic) o exhibir, á vista, felizmente, de poucas pessoas. A vista dos Novos policiaes de Paris correu sem novidade, mas, no momento em que a sombra projectou no panno branco collocado ao fundo da casa de espectaculos, quando todos esperavam que $O$ raio lhes deliciasse a vista, o grito de fogo foi ouvido, - o panico se estabeleceu e atropeladamente sairam todos apavorados com o terrivel alarme. Os rolos de fumo irromperam negros, os visitantes da Exposição correram todos. (...) Já bem adeantado ia o serviço [de salvamento] quando o Corpo de Bombeiros (...) chegou á area das diversões. O fogo então dominava por completo a cupola do pavilhão encimado pela bandeira nacional e ella, com a impetuosidade das chammas, vencendo a força do vento que soprava, como que procurava salvamento, pois, libertada das cordas que queimára, apenas presa na parte superior do mastro, elevava-se para o espaço completamente enrotada no zig-zaguear de uma serpente. E os que assistiam ao triste espectaculo, [a]os gritos, affirmavam que a bandeira brasileira não seria queimada, que ella se salvaria. Uma rajada de vento mais forte, fez cair por terra toda a illusão. O pavilhão nacional, assoberbado por titanica chamma, desappareceu nos ares reduzido a pedaços ennegrecidos. Dez minutos se escoaram. Os bombeiros inertes, tristemente, tinham entre mãos as mangueiras sem despedirem a menor quantidade dagua. E o fogo, a devorar impiedoso o pavilhão, seguia impunemente na sua rota devastadora e pavorosa. $O$ madeiramento do Theatro da Exposição, construido ao lado, começou a estalar, e, minutos depois, tambem se incendiava. Foi nesse momento que a agua appareceu, medrosamente, para, pouco depois, vir com alguma força mais. Devido a essa falta o Corpo de Bombeiros limitou o salvamento ao theatro, pois, o Cinematographo da Exposição foi reduzido a um amontoado de cinzas (...). No momento em que o sinistro se deu achava-se na cabine, collocada sob a cupula, o ajudante de operador Alfredo Risas Brandão, que o attribuiu ao circuito na resistencia, porque, achando-se de costas para elle, ao ouvir um estalo e voltando-se já viu chammas, que procurou abafar com pannos, o que não conseguiu. (...) Affirmaram-nos profissionaes que o incendio não podia ter sido occasionado pela explosão do "O Raio", porque a fita é desenrolada automaticamente pelo apparelho. O prejuizo da empresa Paschoal Segreto foi completo. (...) Infelizmente temos a registrar alguns nomes de feridos que no serviço de extincção [e] no de salvamento foram alvo das chammas e dos estilhaços que se desprenderam do gracioso pavilhão hoje completamente [i]nutilizado. (...) ${ }^{272} \mathrm{O}$ penoso serviço de extincção terminou ás 1 horas e 35 minutos. O serviço de isolamento foi feito por 80 guardas civis, e por um contingente da Força Policial (...). Bado (sic) o incendio no cinematographo, providenciou o empresario Paschoal Segreto [ilegível] de que da cidade viesse um outro apparelho e novas fitas, passando o divertimento a funccionar no logar onde estava o Rink. No Variedades não houve matinée; realizou-se porém o espectaculo da noite, por secções. As demais diversões correram regularmente. Foram totaes os prejuisos. ${ }^{273}$
\end{abstract}

\footnotetext{
${ }^{272}$ Segue uma lista dos feridos: um cabo, quatro guardas civis e dois funcionários de Segreto, tentando apagar o fogo ou salvar objetos.

${ }^{273}$ Exposição Nacional. O dia de hontem. Nas ruas e nos pavilhões. Correio da manhã, 21/09/1908, p. 3.
} 
As "poucas pessoas" que esperavam para assistir ao filme $O$ raio (sugestivo título!) contrastam com a "enorme multidão" que se juntou para observar a sala ser levada abaixo pelo fogo. $\mathrm{O}$ incêndio, que atraiu mais espectadores que a sessão de cinema, foi uma espécie de espetáculo, ao ar livre e gratuito (figura 76). O próprio texto chama o incidente de "triste espetáculo" e o descreve com riqueza de detalhes e tons melodramáticos. A "morte" da bandeira nacional, acompanhada dos gritos da multidão, é marcada por um sentimentalismo patriótico. $\mathrm{O}$ incêndio, aqui, é uma força implacável contra a qual o símbolo nacional luta em vão. Mas, apesar do enorme prejuízo, o show deve continuar. Segreto rearranja suas atrações e, no mesmo dia, busca manter a normalidade no funcionamento de sua área de diversões. 
Exposiço Nacional

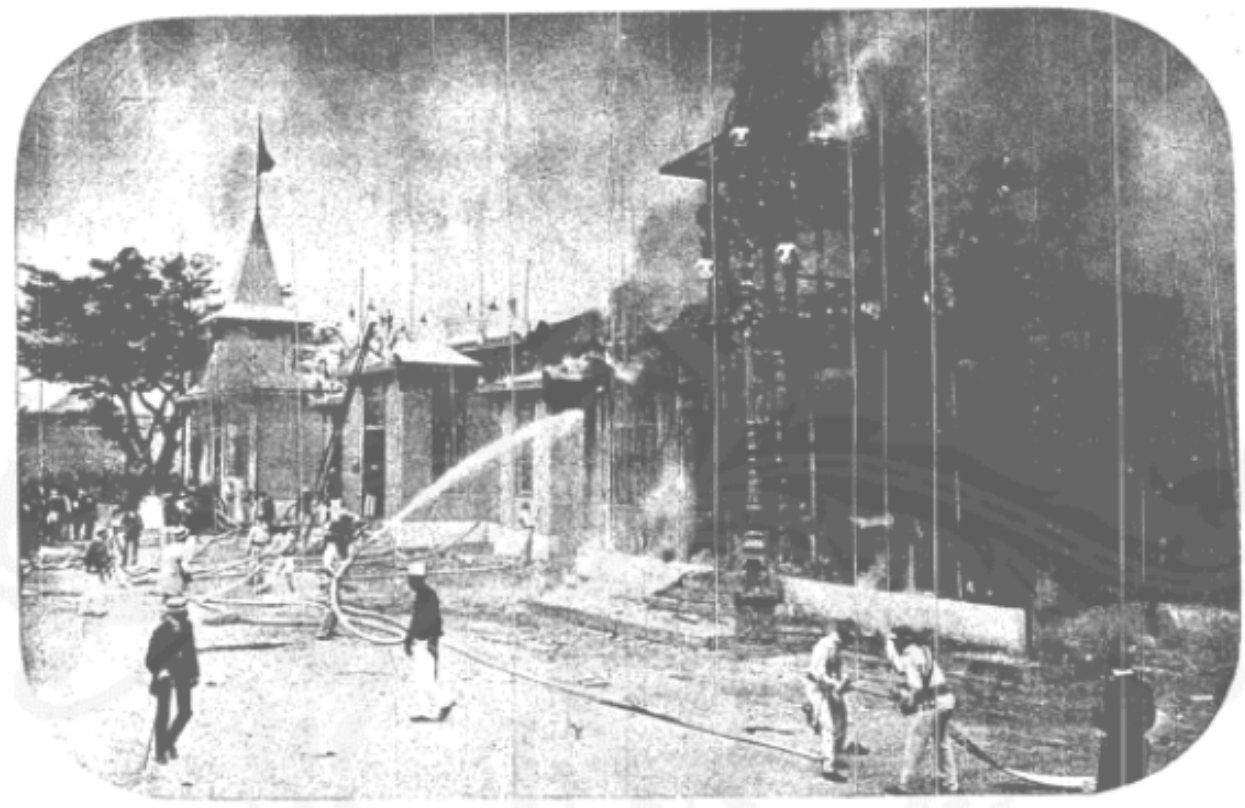

Bombeiros funccionando por occasião do incendio que destruio o ciacmatographo e parte do Theatro Variedades

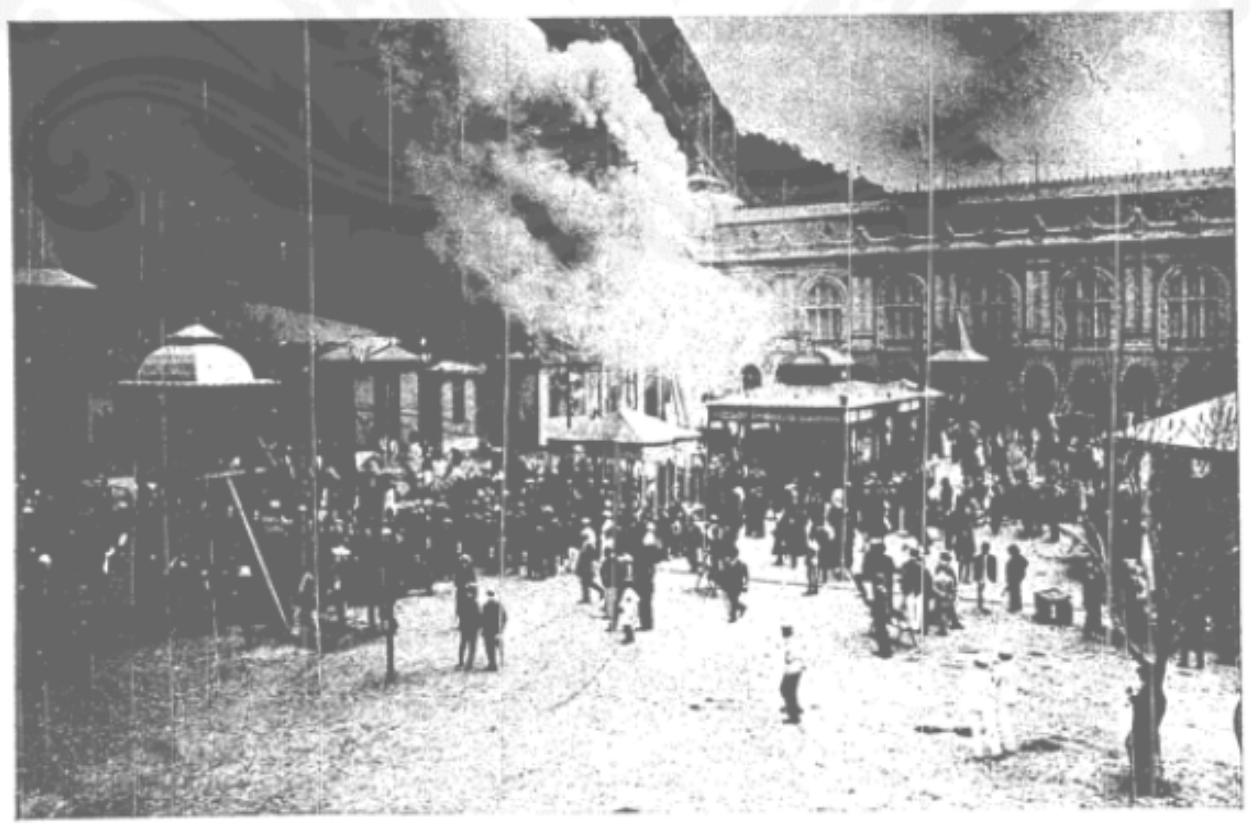

$O$ pove assistindo ao incendio

Figura 15 - Careta. 26/09/1908, p. 14.

Catástrofes causadas pelo fogo eram relativamente comuns desde as primeiras projeções cinematográficas. Incêndios foram, inclusive, o motivo do fim de cinco parques de diversão nos Estados Unidos só no ano de 1911. ${ }^{274}$ Desde o desastre ocorrido em 1897 na pequena sala de projeção de um "Bazar de Caridade" organizado por senhoras da

${ }^{274}$ RABINOVITZ, Lauren. Amusement parks. ABEL, Richard (Ed.). Encyclopedia of Early Cinema. New York: Routledge, 2005, p. 22 
aristocracia parisiense, "a exibição cinematográfica passou a ser sinônimo de perigo de incêndio". ${ }^{275}$ As causas eram comumente ligadas ao próprio funcionamento dos aparelhos: principalmente chamas iniciadas pela substância altamente inflamável (nitrato de celulose) da qual eram feitas as películas, mas também panes nos motores de fornecimento de energia elétrica, por exemplo. Como disse José Inácio de Melo Souza, "a imprensa tinha nos incêndios das salas que exibiam filmes farto material para o sensacionalismo barato, que atraía leitores."276

Pedro Lapera, ao analisar notícias de diferentes incêndios em salas de cinema no Rio de Janeiro do período, aponta justamente para a "dimensão de espetáculo" que esses acontecimentos ganhavam nas palavras impressas. Segundo o autor, a primeira vez que a imprensa brasileira noticiou uma grande queima em uma sessão de cinema foi em 1898, no Animatographo Super Lumière, também empresariado por Segreto, por conta de uma falha no projetor. Além das descrições detalhadas, lista de feridos e contabilização da perda material do proprietário, que vimos na cobertura jornalística do incêndio da Exposição, outro elemento que aparece com frequência nessas matérias são grotescas fotografias e ilustrações, comumente impressas nas capas ou primeiras páginas dos jornais. ${ }^{277}$ Em nosso caso as imagens foram dispensadas, talvez porque o incidente não tenha sido tão grave.

No mesmo Correio da manhã, em outro trecho da nota que acabamos de transcrever, lê-se o seguinte:

\begin{abstract}
Ás 10 horas da noite foram queimados os vinte e um numeros de fogo de artificio, armado na fralda do morro da Babyilonia (sic). Foi magnífica a impressão que causou, apezar do abuso, nas rajadas dos foguetes, de tremendas bombas de dynamite, que tudo faziam estremecer pavorosamente, contribuindo até para boatos de haverem produzido desastres. Mas.. fogo nacional, deante da mais real manifestação de nosso engrandecimento moral e material, toda a gente applaudiu e achou interessante e patriotico.
\end{abstract}

Os fogos de artifício, que por pouco não explodiram no incêndio do cinematógrafo, foram queimados à noite. Os boatos sobre desastres causados pelos estrondos e tremores apontam, mais uma vez, para a proximidade entre espetáculo e catástrofe. E de novo o patriotismo fala mais alto, fazendo tudo terminar em festa.

\footnotetext{
${ }^{275}$ SOUZA, José Inácio de Melo. Salas de cinema e história urbana de São Paulo (1895-1930): o cinema dos engenheiros. São Paulo: Senac, 2016, p. 79.

${ }^{276}$ Idem, p. 80.

${ }^{277}$ LAPERA, Pedro Vinicius Asterito. "Fitas em chammas": cinema, imprensa e sensacionalismo na Belle Époque carioca. Revista brasileira de História, vol. 39, n. 80, 14/03/2019.
} 
A sala de cinema que pega fogo é uma espécie de materialização do mito de origem, que apresentamos a partir da análise do filme Tio Josh na sessão de cinema. $\mathrm{O}$ perigo que a imagem apresenta ao caipira se torna realidade quando o aparato cinematográfico é a própria causa de uma catástrofe. Num incêndio, todos os espectadores são obrigados a agir como os caipiras, correndo para fora da sala de projeção. Ao mesmo tempo, a destruição da máquina cinematográfica é ela mesma espetáculo, atraindo um público até maior que os espectadores da atração propriamente dita. $\mathrm{O}$ casal de caipiras Sô Lotero e nha Ofrasia, numa cena como esta, em vez de destoar como é costumeiro, seria parte de uma multidão que começa como espectadores de cinema, passa a vítimas de um incêndio que correm para salvar suas vidas e volta a posicionar-se como espectadores, agora de um outro tipo de atração. Não é à toa que o desejo por ver a tecnologia sair do controle, num misto de prazer e terror, foi responsável pela criação e enorme sucesso de encenações teatrais de incêndios, como também de inundações e acidentes de trem. ${ }^{278}$

\section{Corpos gigantes, visão panorâmica}

Uma das diversões de Segreto se estendia para fora da área de diversões. Era a Estrada de Ferro Liliputiana (ou Liliputiense): de dentro dos pequenos vagões que percorriam uma estradinha de ferro, os visitantes faziam um passeio no qual podiam observar todo o terreno da Exposição. Esse tipo de trem em miniatura já existia desde a metade do século XIX, mas foi na década de 1890 que se popularizou, principalmente como atração de parques de diversões. ${ }^{279}$ Seus nomes comumente celebravam "a distinção entre escala e potência, materialidade e sentido: o Pequeno Gigante (Eaton Railway, 1905), o Poderoso Átomo (Sutton Park Railway, 1907) [e] o Pequeno Elefante (Halifax Zoo Railway, 1910)."280

\footnotetext{
${ }^{278}$ KIRBY, Lynne. Parallel Tracks: the railroad and silent cinema. Durham: Duke University Press, 1997, p. 61-62.

${ }^{279}$ STEWART, Susan. On longing: Narratives of the miniature, the gigantic, the souvenir, the collection. Durham and London: Duke University Press, 1993, p. 58.

${ }^{280}$ Idem, p. 58.
} 


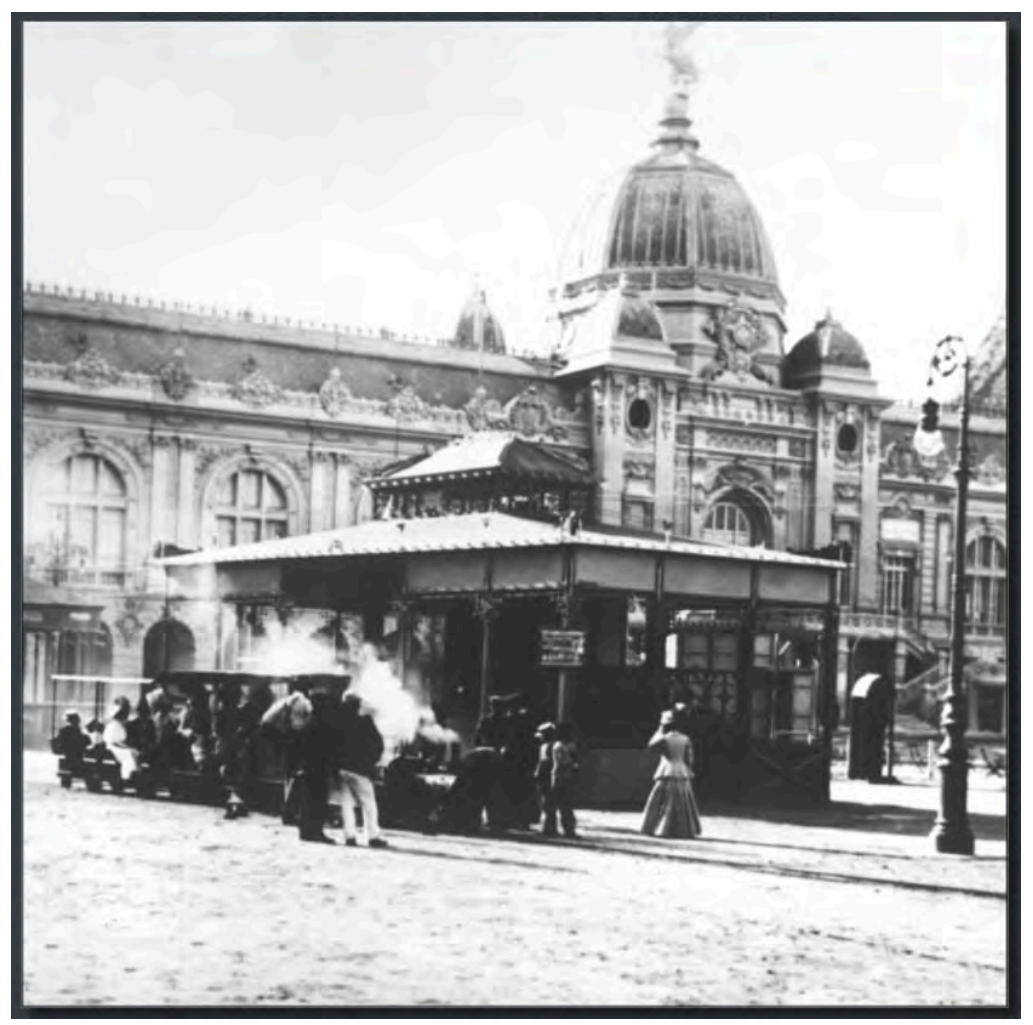

Figura 16 - Estrada de Ferro Liliputiana, uma construção que funcionava possivelmente como estação e o lado posterior do Palácio da Indústria, ao fundo. Acervo Arquivo Nacional.

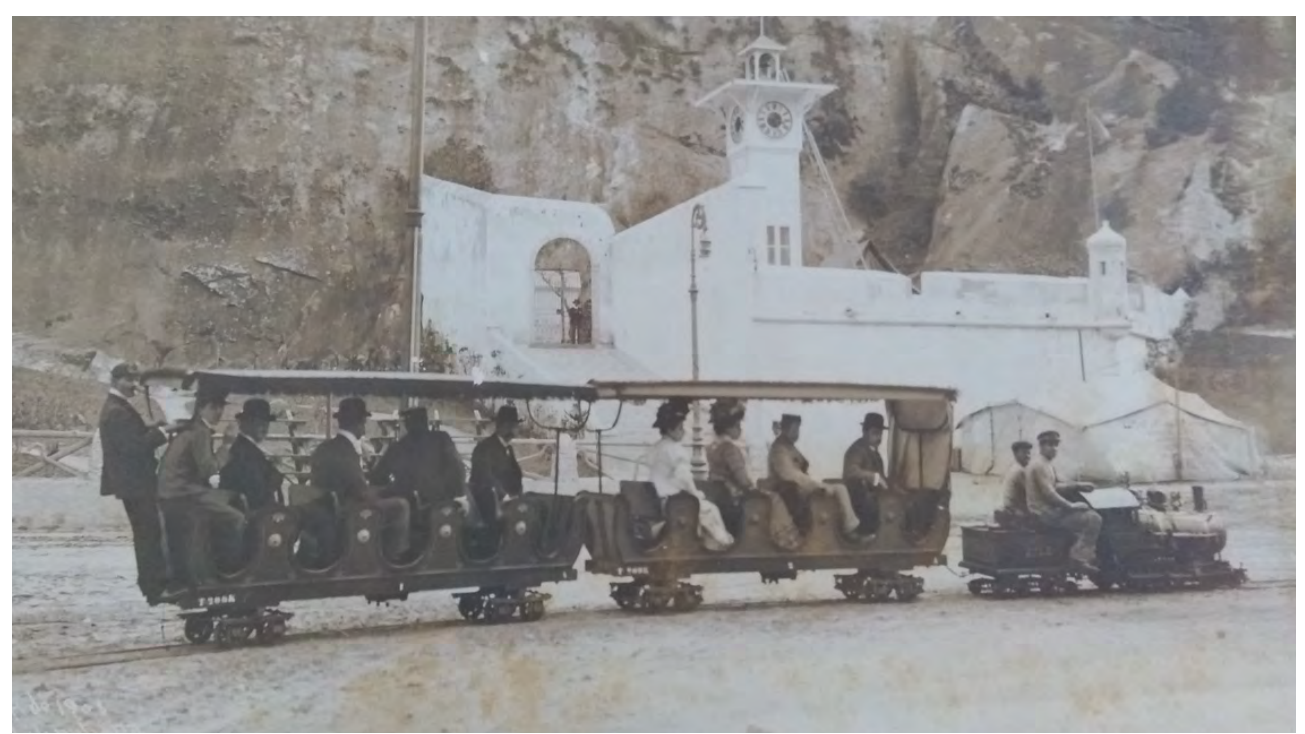

Figura 17 - Estrada de Ferro Liliputiana (detalhe). Acervo MHN.

O nome de nossa locomotiva também brincava com isso, ao refererir-se ao romance As viagens de Gulliver, do irlandês Jonathan Swift (1726). ${ }^{281}$ Sua primeira excursão, como se sabe, é para a ilha de Liliput, cujos habitantes mediam cerca de 15

${ }^{281}$ Cujo título original era Travels into Several Remote Nations of the World. In Four Parts. By Lemuel Gulliver, First a Surgeon, and then a Captain of Several Ships. 
centímetros de altura. Assim como, do ponto de vista dos liliputeanos, Gulliver parecia um gigante, o trenzinho da Exposição promoveu uma impressão de agigantamento dos corpos de seus condutores e passageiros. Erkki Huhtamo, ao tratar dos panoramas em miniatura, explica que "esses dispositivos liliputianos não eram apenas versões menores de shows públicos; a redução de escala mudava sua função". ${ }^{282}$ No caso dos teatrinhos, minipanoramas e afins, analisados pelo autor, sua nova função seria a de promover uma “relação convertível" entre corpo e mídia, permitindo qualquer pessoa de tomar a posição de diretora do espetáculo. No caso da minilocomotiva, talvez a função seja a de sugerir uma domesticação da máquina. Nha Ofrasia, que relutou para embarcar no trem que rumava ao Rio de Janeiro, provavelmente não teria tantos problemas em subir no brinquedo.

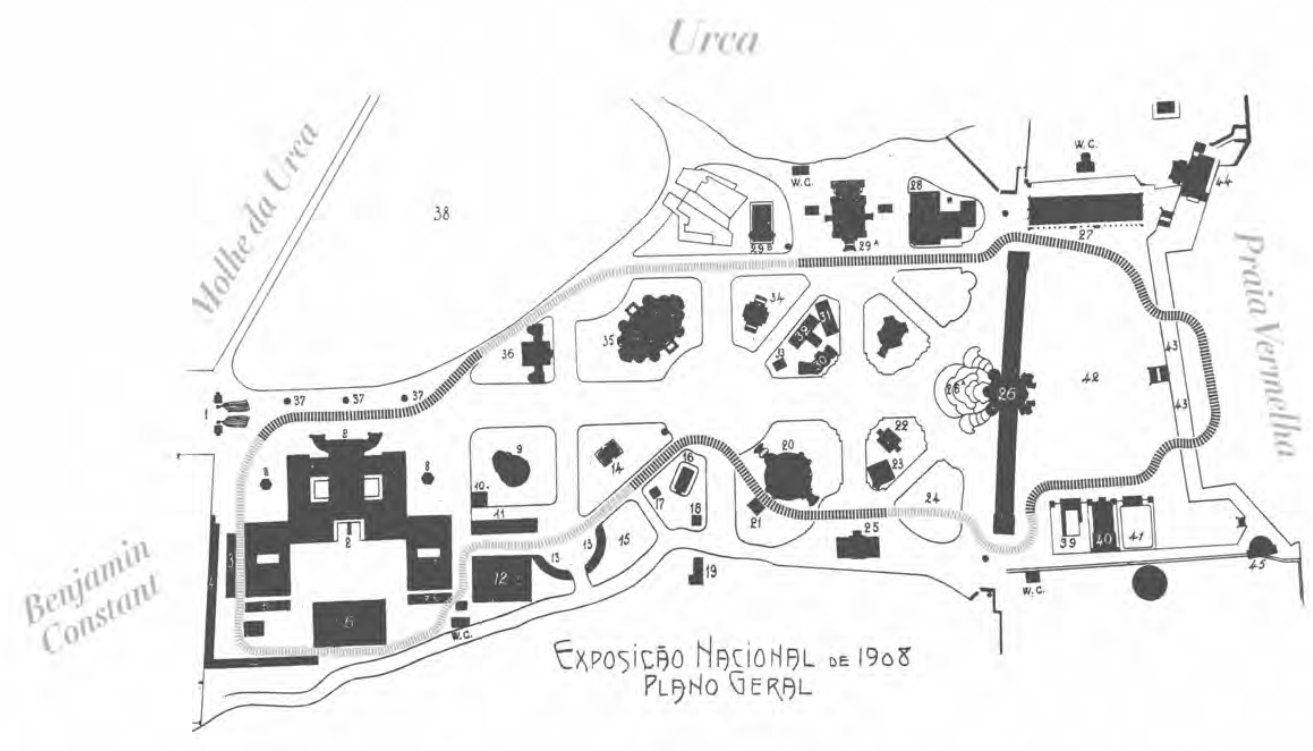

Babilônia

IIIIIIIII Percurso baseado em referênciasfotográficas

IIIIIIIIII Suposta continuação dos trilhos

Figura 18 - Trajeto da Estrada de Ferro Liliputiana sobre o mapa da Exposição, elaborado a partir de referências fotográficas. Guia official, p. 19.

Segundo Susan Stewart, enquanto "a miniatura faz o corpo gigante, o gigantesco transforma o corpo em miniatura, especialmente apontando para os aspectos "de

${ }^{282}$ HUHTAMO, Erkki. Illusions in motion: media archeaology of the moving panorama and related spectacles. Cambridge e Londres: The MIT Press, 2013, p. 368. 
brinquedo" e "insignificante" do corpo". ${ }^{283}$ Esta mudança de perspectiva sobre o corpo humano é o que a arquitetura da Exposição propõe a todo o tempo a seus visitantes fazendo-os passar por enormes pavilhões para depois apreciá-los em forma de maquetes; fazendo-os caminhar por avenidas larguíssimas para depois recorrê-las montados num trem em miniatura. As diferentes escalas encontradas na Exposição transformavam a imagem dos corpos ali presentes, submetendo-os ora a reduções, ora a agigantamentos o que contribui para os simbolismos tanto acerca da grandiosidade do país e da imponência do Rio de Janeiro reformado quanto acerca do domínio humano sobre as máquinas modernas.

As grandes exposições europeias e norte-americanas, nas quais a nossa Exposição foi inspirada, exigiam, segundo Huhtamo, "estruturas especiais de transporte, assim como ferramentas de navegação, como mapas e guias", ${ }^{284}$ já que "os movimentos dos visitantes eram parte do desenho geral". ${ }^{285} \mathrm{Na}$ Exposição Universal de Paris, em 1900, por exemplo, além de uma estrada de ferro que levava os visitantes pelo evento, foi criada também uma enorme esteira rolante. A esteira fez grande sucesso, tendo sido tema de montagens fotográficas, imagens estereoscópicas, charges e até brinquedos. Lumière e Edison a filmaram. ${ }^{286}$ Como os diferentes pavilhões que compunham a exposição estavam em diferentes pontos de Paris, a esteira "transformou uma cidade vibrante em um espetáculo visual panorâmico, no qual cada 'cena' era uma 'imagem viva' cinética". ${ }^{287}$ Esses dispositivos de movimento, tanto na inspiração parisiense de 1900, como no sistema de transporte na Exposição Nacional de 1908, serviram não só para o transporte de seus visitantes, mas também como atrações que provocavam sensações ligadas ao aspecto panorâmico da paisagem urbana, enfatizando os aspectos turístico e espetacular da exposição e, por consequência, da própria cidade. As janelas das casas por onde a esteira de 1900 passava ganharam um sentido muito especial: "no panorama urbano, janelas eram 'peepshows' mostrando vistas da vida interior". ${ }^{288}$ Para aproveitar isso, várias marcas

\footnotetext{
${ }^{283}$ STEWART, Susan. On longing: Narratives of the miniature, the gigantic, the souvenir, the collection. Durham and London: Duke University Press, 1993, p. 71.

${ }^{284}$ HUHTAMO, Erkki. (Un)walking at the Fair: about mobile visualities at the Paris Universal Exposition of 1900. Journal of visual culture, vol. 12(1). Los Angeles, London, New Delhi, Singapore and Washington D.C.: SAGE Publications, 2013, p. 62.

${ }^{285}$ Idem, p. 64.

${ }^{286}$ Vista de uma plataforma móvel, I (Vue d'une plate-forme mobile, I, Sociète Lumière, 1900) e mais quatro filmes com este tema (Cf. Catalogue Lumière. Disponível em: < https://cataloguelumiere.com/series/la-plate-forme-mobile/ >. Acesso em: 11/04/2018). Panorama de uma calçada movente (Panorama from the moving boardwalk, Edison Co., 1900).

${ }^{287}$ HUHTAMO, Erkki. Op. cit., p. 73.

${ }^{288}$ Ibidem.
} 
alugaram janelas para anunciar seus produtos, usando inclusive bonecos de cera que geralmente simulavam moças bonitas para chamar a atenção do público que passava na passarela mecânica.

Segundo Maria Eliza Borges, os recursos publicitários da Exposição brasileira "mobilizavam a conexão entre olhos, ouvidos, boca e tato". Segundo a autora,

\footnotetext{
enquanto os olhos passeavam pela profusão de suportes contendo imagens dos produtos nacionais, alocadas nas paredes dos pavilhões, sabores e aromas distintos cativavam os visitantes que eram convidados a provar diferentes tipos de cafés, chás, doce de leite, queijos, dentre outras guloseimas dos diferentes estados brasileiros. ${ }^{289}$
}

Além disso, o próprio espaço da Exposição, seu mobiliário e sua paisagem, foram usados como superfície publicitária para seus diferentes patrocinadores. Nas fotos do evento aparecem inúmeros anúncios em bancos, telhados e até nas pedras do morros. A paisagem é, literalmente, consumível.

${ }^{289}$ BORGES, Maria Eliza Linhares. A Exposição Nacional de 1908 e a produção da identidade nacional brasileira. In: Anais do Museu Histórico Nacional, vol. 40, 1998, p. 87-88. 

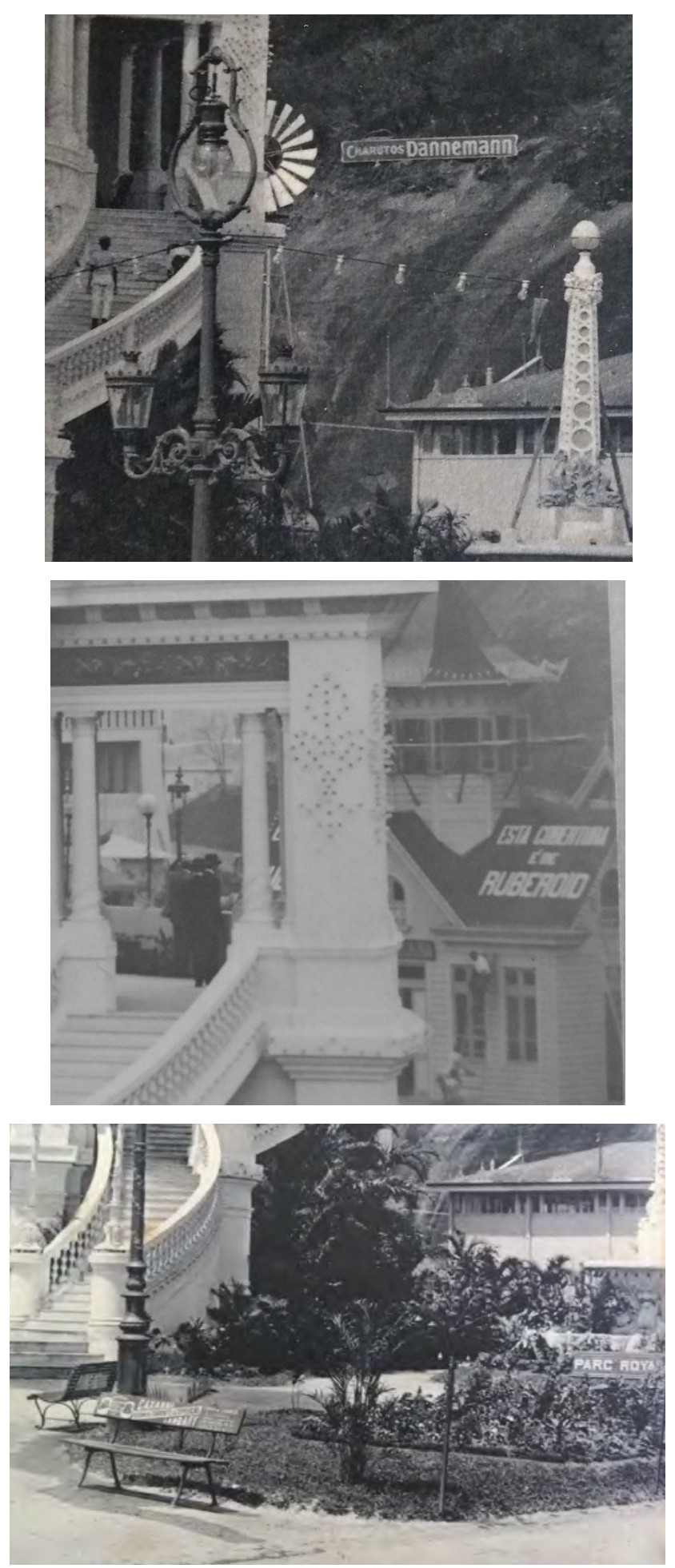

Figuras 80, 81 e 82 - Detalhes de diferentes fotografias. Acervo MHN.

Dos vagões do trenzinho tinha-se uma visão privilegiada não só da paisagem da Exposição, mas também desses anúncios, principalmente aqueles afixados em lugares altos, valorizados pela visão à distância.

Assim como Liliput era uma ilha, característica que a isolava de outros lugares cuja escala respeitaria as dimensões do mundo real, a Exposição era isolada do resto da 
cidade, não só pelas peculiaridades do local onde foi montada (entre morros e mar), mas também por ser rodeada por muros. O recinto era como uma cidade em miniatura dentro da cidade. A casa de bonecas também estabelece uma relação metonímica com a casa que a abriga, segundo Susan Stewart. "Uma casa dentro de uma casa", a casa de bonecas "apresenta a articulação que a casa faz da tensão entre esferas internas e externas." 290 Segundo a autora, "a casa de bonecas é consumida [prioritariamente] pelo olho", ${ }^{291}$ assim como a Exposição. Para Stewart, "a redução em escala que a miniatura apresenta torce as relações de tempo e espaço do mundo da vida cotidiana e, como um objeto consumido, a miniatura encontra seu "valor de uso" transformado em um tempo infinito de devaneio". ${ }^{292}$ É similar ao que parece acontecer na Exposição, cidade fantasia da elite carioca, dedicada ao consumo sensorial de produtos, imagens e símbolos de um progresso nacionalista.

\section{"O roceiro que vai à cidade tem certeza trazer novidade"}

Saindo da Exposição, o que mais os caipiras poderiam ter feito para aproveitar sua visita ao Rio de Janeiro? Encontramos uma pista em uma canção chamada Seu Anastácio chegou de viagem, de autoria do trombonista carioca Cláudio Pereira da Silva:

\footnotetext{
Seu Nastaço chegô de viage

Nós viemo sabe como istá;

É di nós o que é mais curioso

Há de tê qualquer coisa a contá.

Tem razão, meus amigo, ora iscute:

$O$ rocêro qui vai na cedade

Se não morre de febre amarela

Tem certeza trazê novidade.

Lá na casa em que fui hospedado

C'o cumpadre Rimão Lidogéro,

Seu Antonho, que é moço sabido,

Mi levô no lugá do crotéro.

Prá dizê que é igreja não é:

Mas aquele qui morre matado,

A puliça encafua lá dentro,

C'um um porco vai sê retaiado.

Pois o causo qui vô lhes contá
}

\footnotetext{
${ }^{290}$ STEWART, Susan. On longing: Narratives of the miniature, the gigantic, the souvenir, the collection. Durham and London: Duke University Press, 1993, p. 61.

${ }^{291}$ Idem, p. 62.

${ }^{292}$ Idem, p. 65.
} 
Faz a gente ficá socombida,

Só intêro se enterra na cova

Os qui morre de morte morrida.

(...)

Cruz, canhoto! Repetem em coro

Os matutos com tal narração.

Toma figa, marvados, rabudo,

Inemigo de Deus, tentação!...

Um a um se esgueirou assombrado

Indo aos outros narrar o que ouviu,

Desde então ao fatal Necrotério

Nunca mais um matuto afluiu. ${ }^{293}$

Na canção, a "novidade" que o caipira traz da cidade é o necrotério. Mais uma vez, no encontro entre caipira e cidade, a espetacularização da destruição do corpo é protagonista. A oposição entre "morte matada" e "morte morrida" aponta para a distinção entre o mundo urbano e o mundo rural. Na cidade, onde reina a "tirania do acaso", 294 a morte pode ser produzida por máquinas as mais diversas, quando menos se espera. O que surpreende seu Anastácio é o que se faz com os corpos de vítimas de mortes "nãonaturais", violentas. A história deixa "a gente socombida", palavra que remete às ideias de "dobrar-se", “vergar", "não resistir", “ceder" e mesmo "morrer”. Ao ouvir o causo, os caipiras vão embora, assustados. Segundo José Ramos Tinhorão, a graça da letra "residia na incompreensão do matuto Anastácio diante da providência legal de conduzir os corpos das vítimas de morte violenta ou misteriosa para o necrotério, a fim de serem autopsiados para determinação da causa mortis.” ${ }^{295}$ A história, composta em 1908 como número musical de espetáculo de teatro, teve tanto sucesso, que, no mesmo ano, foi "transformada na primeira comédia do cinema brasileiro, com Anastácio sendo interpretado pelo ator José Gonçalves Leonardo, que seria chamado a gravar a música em disco". ${ }^{296}$ A comédia comentada por Tinhorão é Nhô Anastácio chegou de viagem, filme já citado por nós, que se aproxima de Sô Lotero e nhá Ofrasia... pela presença de protagonistas caipiras.

Era comum encontrar, nos jornais e revistas cariocas da época, fotografias sinistras de cadáveres no necrotério. Os mortos "dignos" de tal divulgação costumavam

${ }^{293}$ Apud TINHORÃO, José Ramos. A música popular no romance brasileiro Vol. III: século XX, $2^{\mathrm{a}}$ parte. São Paulo: Editora 34, p. 126.

${ }^{294}$ SINGER, Ben. Modernidade, hiperestímulo e o início do sensacionalismo popular. In: CHARNEY, Leo; SCHWARTZ, Vanessa R. (Orgs.). O cinema e a invenção da vida moderna. São Paulo: Cosac Naify, 2004, p. 110.

${ }^{295}$ TINHORÃO, José Ramos. A música popular no romance brasileiro Vol. III: século XX, $2^{\text {a }}$ parte. São Paulo: Editora 34, p. 126-7.

${ }^{296}$ Idem, p. 125. 
ser personalidades da elite política e cultural da época ou anônimas vítimas de mortes violentas. Este era um tema tão popular, que uma série de produções fílmicas, os chamados "filmes criminais"297, foi alimentada por essas histórias reais. Os estranguladores (Photo-Cinematographia Brasileira, 1908), por exemplo, filmado pelo próprio Antônio Leal (o mesmo operador responsável por Sô Lotero e nha Ofrasia...), foi exibido 830 vezes em apresentações contínuas desde sua estreia em 3 de agosto de 1908, chegando ao número de 20 mil espectadores só no primeiro mês. ${ }^{298} \mathrm{O}$ episódio que o filme retratava ficou conhecido como "O crime da rua da Carioca", sobre o qual JeanClaude Bernardet cita

\begin{abstract}
o número de outubro de 1906 da elegantísssima revista Kosmos que, sob o título, provavelmente nada ingênuo, de "Um crime empolgante", [que] publica fotos macabras dos "estranguladores do Rio": Paulino Fuoco com a corda no pescoço no quarto em que foi estrangulado; depois no necrotério com Carlo Fuoco, ambos com o rosto inchado, a indicar consequências do estrangulamento ou mesmo um início de putrefação. E esse "empolgante" não pode deixar de nos alertar sobre o tipo de relações mantidas pelos cariocas com a criminalidade no Rio de Janeiro do fim do século XIX e inícios do XX, e com sua representação jornalística, teatral e cinematográfica, relações das quais o fascínio muito provavelmente não estava excluído. ${ }^{299}$
\end{abstract}

É o que Vanessa Schwartz, ao analisar o necrotério de Paris no final do século XIX, chama de gosto do público pela realidade. ${ }^{300}$ Segundo a autora, "o necrotério serviu como um auxiliar visual do jornal, colocando no palco os mortos que haviam sido descritos em detalhe, com sensacionalismo, pela palavra impressa". ${ }^{301}$ Quando os jornais noticiavam mortes enigmáticas ou decorrentes de crimes violentos, multidões se dirigiam ao necrotério parisiense só para olhar aqueles corpos arruinados.

Já vimos os corpos dos caipiras serem afetados, observados e subjugados pelo mundo urbano - materializado em roupas apertadas, trens velozes, restaurantes elegantes, em um incêndio arrasador, na arquitetura da Exposição. Como o "confronto empolgante" com que termina o filme Tio Josh na sessão de cinema e o "crime empolgante" publicado na revista Kosmos, o final de Sô Lotero e nha Ofrasia... poderia ser uma empolgante visita

\footnotetext{
${ }^{297}$ BERNARDET, Jean-Claude. Historiografia clássica do cinema brasileiro: metodologia e pedagogia. São Paulo: Annablume, 2008, p. 66-74.

${ }^{298}$ SOUZA, José Inácio de Melo. Imagens do passado: São Paulo e Rio de Janeiro nos primórdios do cinema. São Paulo: Editora Senac, 2004, p. 247.

${ }^{299}$ BERNARDET, Jean-Claude. Op. cit., p. 70.

${ }^{300}$ SCHWARTZ, Vanessa. O espectador cinematográfico antes do aparato do cinema: o gosto do público pela realidade na Paris fim-de-século. CHARNEY, Leo; SCHWARTZ, Vanessa R. (Orgs.). O cinema e a invenção da vida moderna. São Paulo: Cosac Naify, 2004, p. 337.

${ }^{301}$ Idem, p. 340.
} 
ao necrotério para ver os "mortos da vez" com seus próprios olhos, sem a mediação da fotografia, da ilustração, do cinema ou do jornalismo. Se tomarmos como modelo a reação de seu Anastácio na canção que comentamos acima, os caipiras teriam provavelmente saído apavorados.

Em nosso percurso de sugestão imaginativa do filme brasileiro perdido, Sô Lotero e nhá Ofrasia, acompanhados por nós, chegamos ao Rio de Janeiro, entramos em uma confeitaria da moda, passamos pela Porta Monumental da Exposição, visitamos seus diferentes pavilhões, sobrevivemos e assistimos a um incêndio, fizemos um passeio no trenzinho de brinquedo e acabamos no necrotério. O filme provavelmente uniu vistas panorâmicas da cidade e da Exposição a curtas esquetes em que as personagens apareciam agindo de modo a destoar do entorno. Seus corpos foram mastigados pela cidade. A mulher, ela mesma um perigo no caso de Tio Josh..., é aqui não só a personagem mais medrosa, que suspeita das máquinas modernas, mas também a que mais é afetada por elas. Se nosso filme foi uma "crítica da atualidade", como dizia uma propaganda, provavelmente mostrou os caipiras em situações que favoreciam a ambiguidade entre modernidade e catástrofe.

A Exposição funcionou como um espelho encantado que refletiu o que havia de mais moderno na cidade do Rio de Janeiro, como suas novas avenidas largas e grandiosas construções europeizadas. O evento buscava oferecer uma "experiência total", ao reunir espaços educativos, atrações de entretenimento, além de restaurantes e locais de descanso. Tudo isso num passeio que podia durar algumas horas. Ela foi uma miniatura de cidade e de país, operando uma didática por meio da distinção. Do mesmo modo que o espectador citadino se diferencia do caipira que foge de um trem feito de sombras, ele também o faz com relação ao casal de caipiras em visita à Exposição. Mas não é só isso. 


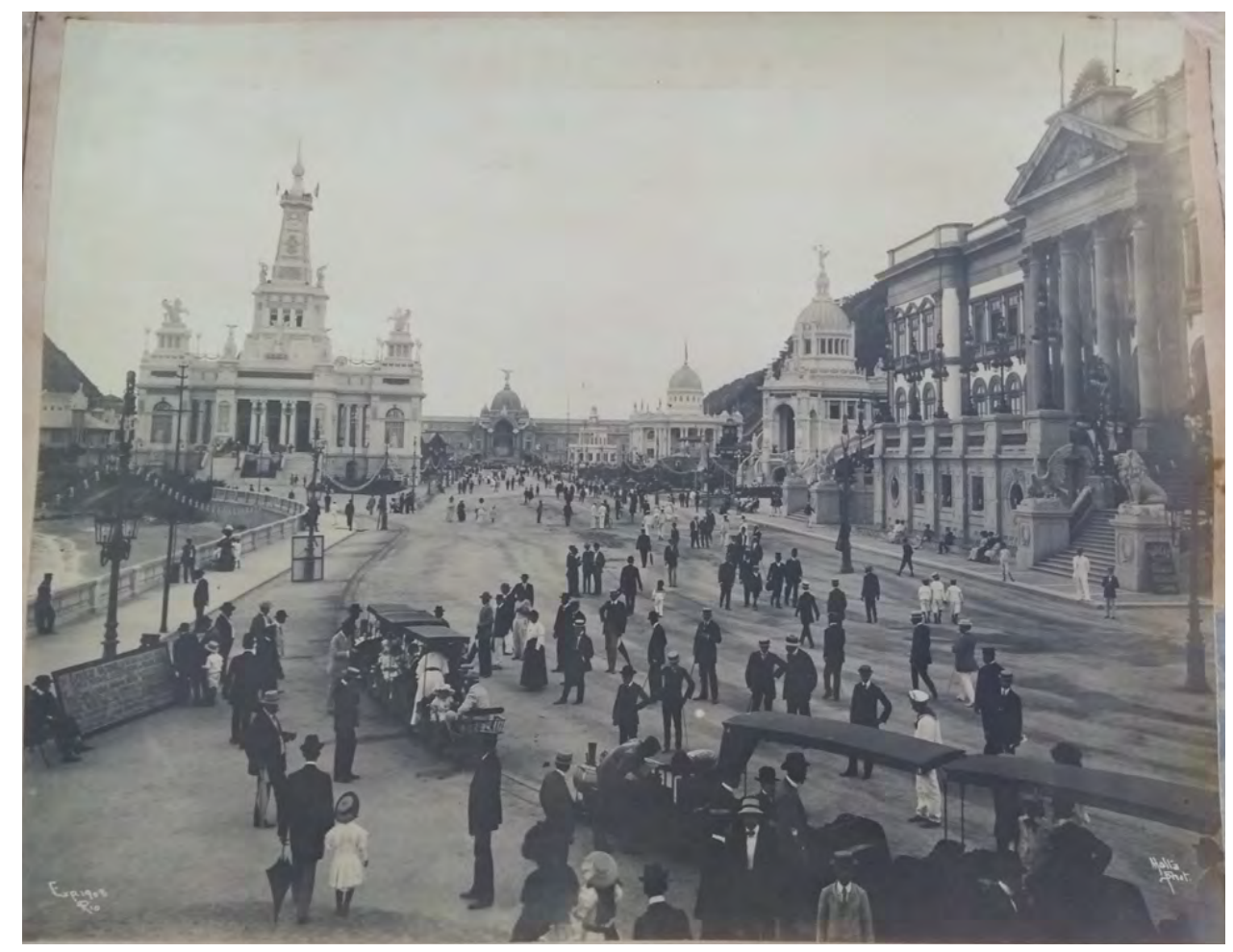

Figura 83 - Exp. 1908. Rio. Malta Phot. Acervo MHN.

Predominantemente, nossas personagens destoaram na cena urbana, sendo ridicularizados pelos citadinos por suas reações exageradas aos aparatos modernos. Mas os mesmos citadinos, sempre tão contidos e "civilizados", também agiram como caipiras - na sala de cinema em chamas, no espetáculo estrondoso dos fogos de artifício e frente às câmeras da produção do filme, tentando aparecer. O mundo urbano que assombra os caipiras era também novidade para o cidadão da capital federal, que acabara de ver sua velha cidade ser botada abaixo para a construção de novas avenidas e edifícios, por onde passavam a circular novos veículos e multidões. Assim como o chalé rústico de Santa Catarina, os caipiras compõem a paisagem urbana como aquelas figuras que, ao mesmo tempo em que enfatizam a modernidade de seu entorno (por contraste), representam algo genuíno, nacional e que materializa medos e ansiedades generalizadas. 


\section{Considerações finais}

A exibição cinematográfica apresenta diversos problemas para os historiadores. Charles Musser ${ }^{302}$ nos lembra que, no primeiro cinema, isso acontece porque os contextos em que os filmes foram exibidos eram muito diversos e não há documentação que se refira à grande maioria das sessões. Essa dificuldade parece pequena quando comparada com a problemática da pesquisa sobre os espectadores do período. Muito raramente encontramos comentários detalhados sobre os filmes ou salas de cinema em publicações da época. Não havia crítica especializada. Muitas vezes, o acesso que temos a informações sobre determinado filme ou sessão é por meio de comentários dispersos publicados em jornais por cronistas que podiam estar a serviço de determinados objetivos, buscando exaltar ou depreciar a atividade cinematográfica, por exemplo.

Uma das fontes para pensar o público são os próprios filmes, claro, de cujo discurso o espectador é alvo. Como entidade hipotética, ele pode ser determinado por meio das próprias estratégias formais das obras. Mas, no caso do primeiro cinema, em que os filmes eram exibidos em contextos diversos que influenciavam enormemente a recepção, a análise fílmica é insuficiente. Para a maioria dos casos do cinema antigo brasileiro esse tipo de análise não é nem mesmo possível, por conta da ausência quase total de filmes sobreviventes.

É por isso que a historiografia dedicada ao cinema das origens tem analisado os contextos específicos de exibição dos primeiros filmes, apontando para as enormes diferenças com relação ao cinema posterior. Em vez de analisar o período com o olhar marcado pelo cinema narrativo, como vinham fazendo os pesquisadores anteriores, os historiadores do primeiro cinema vêm buscando, desde a década de 1980, nas práticas de exibição de imagens da virada do século XIX para o XX, os contextos que permitem compreender as especificidades do primeiro cinema.

Nesse sentido, Jonathan Crary faz uma distinção etimológica entre os termos “observador" e "espectador". Ele opta por chamar o objeto de sua pesquisa (que abrange fenômenos como o zootrópio, o diorama e o estereoscópio) de "observador" para ressaltar

\footnotetext{
${ }^{302}$ MUSSER, Charles. The emergence of cinema: the american screen to 1907. Berkeley / Los Angeles: University of California Press, 1990, p. 7.
} 
o sentido de "observa[r] regras, códigos, regulamentos e práticas", ${ }^{303}$ em vez do gesto simples de "olhar para", que é o significado da raiz latina de "espectador". O sujeito observador é aquele que vê de acordo com um sistema de convenções e limitações, sempre resultado de um conjunto de relações discursivas, sociais, tecnológicas e institucionais.

Aqui, o espectador apareceu predominantemente como uma espécie de jogador. Por meio de operações de identificação com símbolos considerados modernos e de distinção social, as diferentes personagens (fictícias e históricas) dos três episódios analisados nesta dissertação competiram entre si, numa cidade em disputa, por visibilidade, excitação sensorial e status social. Na cultura visual do Rio de Janeiro no início do século passado, personagens não urbanas corporificaram, de modo visceral, as mudanças que vinham alterando de forma radical as vidas de todos, enquanto os membros da elite e das chamadas "camadas médias", demasiado preocupados com sua "cultura profundamente eurófila", ${ }^{304}$ optavam por fingir costume. Quem melhor que um forasteiro "ingênuo" para servir de mediação aos sentimentos ambíguos despertados pelas transformações pelas quais a cidade passava?

${ }^{303}$ CRARY, Jonathan. Técnicas do observador: visão e modernidade no século XIX. Rio de Janeiro: Contraponto, 2012, p. 15.

${ }^{304}$ NEEDELL, Jeffrey. Belle Époque tropical: sociedade e cultura de elite no Rio de Janeiro na virada do século. São Paulo: Companhia das Letras, 1993, p. 273. 


\section{Referências}

\section{Bases de dados utilizadas}

Cine Silencioso: Filmes estrangeiros exibidos no Brasil 1896-1916. Disponível em: http://mnemocine.com.br/JCB/visualizar.php?id=451

Cinemateca Brasileira. Disponível em: http://bases.cinemateca.gov.br

Filmografia Brasileira da Cinemateca Brasileira. Disponível em:

http://cinemateca.org.br/filmografia-brasileira/

Forum et galerie de cartes postales anciennes de France. Disponível em: < http://www.cparama.com/forum/automobiles-et-voitures-f158.html >.

Internet Archive.

Library of Congress.

\section{Filmes citados}

70 anos de Brasil: da Belle Époque aos nossos dias (Jurandyr Noronha, 1972)

A dança da serpentina (Serpentine dance, Edison, 1896).

A lanterna mágica (La lanterne magique, Georges Méliès, 1903)

A porta errada (Erreur de porte, Pathé Frères, 1904)

A primeira vez que o camponês viu as imagens animadas (The countryman's first sight of the animated pictures, Paul's Animatograph Works, 1901)

A trip through China (1902)

A trip through Samoa and the Fiji (Selig, 1905)

Almoço aos conselheiros argentinos no Pavilhão Nacional de Agricultura (Empresa Paschoal Segreto, 1908)

Ascensão ao Pão-de-Açúcar (Empresa Paschoal Segreto, 1908)

Avenida Central apanhada de dentro de um automóvel (1907)

Baía de Guanabara (Antonio Leal, 1907)

Barão do Rio Branco - A nação em luto - Os funeraes (Alberto Botelho, 1912)

Belezas turísticas (A. Botelho Film, 1908)

Caça à raposa (Antonio Campos, 1913)

Chegada do primeiro automóvel a Curitiba (1907)

Chegada do trem a estação de Ciotat (Arrivée d'um train en gare à la Ciotat, Société Lumière, 1895)

Circuito de carrinhos de mão ou Circuito... a pé (Le circuit des voitures à bras, Pathé Frères, 1908)

Circuito de Diepe ou Uma corrida de automóveis em Dieppe (Circuit de Dieppe, Pathé Frères, 1907)

Circuito de São Gonçalo ou Corridas de automoveis em São Gonçalo (Empresa F.

Serrador, 1909)

Circuito de São Gonçalo: O circuito de Itapecerica (Antônio Leal, 1908) 
Como é ser atropelado (How it feels to be run over, Hepworth Manufacturing, 1900)

Corridas de automóveis para meninos (Kid auto races at Venice, Henry Lehrman, 1914)

Corso de Botafogo (Photo-Cinematographia Brasileira, 1908)

Dançarina parisiense (Parisian dancer, Edison, 1897)

De Belém a Palmeiras (Casa Marc Ferrez, 1908)

Estréia de um chauffeur ou Estréia de um automobilista (Débuts d'un chauffeur, Pathé Frères, Georges Hatot, 1906)

Exemplo regenerador (José Medina, 1919)

Explosão de um veículo motorizado (Explosion of a motor car, Hepworth Manufacturing, 1900)

Grandes carreiras de automóveis (Circuit de la Sarthe, Pathé Frères, 1906)

Inauguração da Exposição Nacional (Photo-Cinematographica Brasileira, 1908)

Inauguração das linhas elevadas (Casa Marc Ferrez, 1908)

Izabel, condutora de automóveis (Mabel at the wheel, Mabel Normand e Mack Sennett, 1914)

Le repas de bébé (Société Lumière, 1895)

Motorista e mulher cocheiro ou Chauffeur e mulher cocheira (Chauffeur et cochère, Pathé Frères, 1909)

Nhô Anastácio chegou de viagem (Arnaldo \& Cia., 1908)

O balão do Capitão Lippi (Empresa Paschoal Segreto)

O cachorro chauffeur (1908)

O Circuito de Dieppe 1908 ou Nos arredores de Dieppe (Circuit de Dieppe, Pathé Frères, 1908)

O circuito de Itapecerica (Photo-Cinematographia Brasileira, 1908)

O corso de 19 de fevereiro (William \& Cia, 1908)

O corso de carruagens na exposição (Empresa Paschoal Segreto, 1908)

O corso de carruagens na exposição (Jácomo Rosário Staffa, 1908)

O corso de carruagens na exposição (Labanca, Leal \& Cia, 1908)

O corso das quartas-feiras na Avenida Beira Mar (1908)

O grande roubo do trem (The great train robbery, Edison, 1903)

O homem da cabeça de borracha (L'homme à la tête de caoutchouc, Georges Méliès, 1901)

O homem do Sputnik (Carlos Manga, 1959)

O melômano (Le mélomane, Georges Méliès, 1903)

O motorista insano (The '?' motorist ou The mad motorist, Paul's Animatograph Works, Walter R. Booth, 1906)

O percurso Paris-Monte Carlo em duas horas (Le raid Paris-Monte-Carlo en deux heures, Georges Méliès, 1905)

O príncipe herdeiro da Itália em terras do Brasil (Botelho Film, 1924)

O sonho de um chofer (The chauffeur's dream, Charles Urban, Walter R. Booth, 1908)

Os estranguladores (Photo-Cinematographia Brasileira, 1908)

Pan-American Exposition by night (Edison, 1901)

Panorama de uma calçada movente (Panorama from the moving boardwalk, Edison, 1900)

Rube e Mandy em Coney Island (Rube and Mandy at Coney Island, Edison, 1903)

Salvo pelo Rover (Rescued by Rover, Hepworth, 1905)

San Francisco earthquake and fire (1906)

Sô Lotero e nhá Ofrasia com seus productos na Exposição (Labanca, Leal \& Cia., 1908)

Sociedade Anônima Fábrica Votorantim (1922)

Tempo de guerra (Les Carabiniers, Jean-Luc Godard, 1963) 
Tio Josh na sessão de cinema (Uncle Josh at the moving-picture show, Edison, 1902)

Uma colisão ferroviária (A railway collision, R. W. Paul, 1900)

Uma viagem ao Monte Tamalpais (A Trip Down Mount Tamalpais, Irmãos Miles, 1906)

Uma viagem pela Market Street antes do incêndio (A trip down Market Street before the fire, Irmãos Miles, 1906)

Viagem através do impossível (Voyage à travers l'impossible, Georges Méliès, 1904)

Vista de uma plataforma móvel, I (Vue d'une plate-forme mobile, I, Sociète Lumière, 1900)

Vistas de São Paulo e Santos (Empresa J. Cateysson, 1907)

\section{Jornais consultados}

A capital

A federação

A imprensa

A notícia

A opinião pública

Correio da manhã

Correio do povo

Correio paulistano

Gazeta de notícias

Jornal da exposição

Jornal do Brasil

Jornal do commercio

O paiz.

\section{Revistas consultadas}

Careta

Fon-Fon!

Kosmos

O malho

$O$ maxixe

\section{Referências gerais}

ARAÚJO, Vicente de Paula. A Bela Época do Cinema Brasileiro. São Paulo: Editora Perspectiva, 1976.

. Salões, circos e cinemas de São Paulo. São Paulo: Editora Perspectiva, 1981.

ARGAN, Giulio Carlo. Arte moderna. São Paulo: Companhia das Letras, 2010.

AUERBACH, Jonathan. Chase films. In: ABEL, Richard (Ed.). Encyclopedia of Early Cinema. New York: Routledge, 2005. 
AUGUSTO, Sérgio. Este mundo é um pandeiro: a chanchada de Getúlio a JK. São Paulo: Companhia das Letras, 1989.

AZEVEDO, Artur. Teatro a Vapor - Organização, introdução e notas de Gerald M. Moser (do State College, Pensilvânia, EUA). São Paulo: Editora Cultrix, 1977.

BARKER, W. G.; HEPWORTH, C. M.; PAUL, R. W. Before 1910: Kinematograph experiences. In: Proceedings of the British Kinematograph Society. No. 38. Londres: BKS, 1936, $\quad$ s. p. Disponível em: < http://brianpritchard.com/1910\%20Kinematograph\%20Experiences.htm >. Acesso em: 03/01/2018.

BERNARDET, Jean-Claude. Cinema brasileiro: propostas para uma história. São Paulo: Companhia das Letras, 2009 [1979].

. Circuito de São Gonçalo 1909-43. Filmografia do cinema brasileiro 19001935: Jornal o Estado de S. Paulo (levantamento feito por Jean-Claude Bernardet). São Paulo: Secretaria de Cultura, Comissão de Cinema, 1979.

Historiografia clássica do cinema brasileiro: metodologia e pedagogia.

São Paulo: Annablume, 2008.

BORGES, Maria Eliza Linhares. A Exposição Nacional de 1908 e a produção da identidade nacional brasileira. In: Anais do Museu Histórico Nacional, vol. 40, 1998.

BOTTOMORE, Stephen. The panicking audience?: early cinema and the "train effect". Historical Journal of Film, Radio and Television, Vol. 19, No. 2. Londres: Taylor \& Francis, 1999.

CARVALHO, Danielle Crepaldi. Luz e sombra no écran: realidade, cinema e rua nas crônicas cariocas de 1894 a 1922. Campinas, Unicamp, 2014. Tese (Doutorado em Teoria e História Literária).

CHARNEY, Leo; SCHWARTZ, Vanessa R. (Orgs.). O cinema e a invenção da vida moderna. São Paulo: Cosac Naify, 2004.

CHRISTIE, Ian. R. W. Paul: the collected films 1895-1908. British Film Institute: encarte de DVD, sem data.

CINEMATECA BRASILEIRA (Org.). Coleção de memoriais descritivos acompanhando pedidos de privilégios e patentes de invenções relacionadas com o meio cinematográfico. Fornecida por José Inácio de Melo Souza a partir de pesquisa no Arquivo Nacional. Pasta D1329f.

COSTA, Flavia Cesarino. O primeiro cinema: espetáculo, narração, domesticação. São Paulo: Azougue Editorial, 2005. 
- Figuras populares no documentário silencioso brasileiro. Imagofagia: Revista de la Asociación Argentina de Estudios de Cine y Audiovisual, No. 8, 2013, p. 8. Disponível em:

http://www.asaeca.org/imagofagia/index.php/imagofagia/article/view/493/421 >. Acesso em: 10/04/2018.

CRARY, Jonathan. Técnicas do observador: visão e modernidade no século XIX. Rio de Janeiro: Contraponto, 2012.

DI GIACOMO, Carolina Azevedo. O espectador como passageiro: os simuladores de viagem do primeiro cinema no Brasil (1906-1908). Vivomatografías. Revista de estudios sobre precine y cine silente en Latinoamérica, No. 1, Dezembro 2015. Disponível em: $<$ http://www.vivomatografias.com/index.php/vmfs/article/view/11 >. Acesso em: 20/07/2019.

ELSAESSER, Thomas (Ed.). Early cinema: space, frame, narrative. British Film Institut, 2008.

2018.

. Cinema como arqueologia das mídias. São Paulo: Edições Sesc São Paulo,

FIELDING, Raymond. Hale's Tours: Ultrarealism in the pre-1910 motion Picture. In: FELL, John L. (ed.), Film Before Griffith. University of California Press: Berkeley and Los Angeles, California, 1983.

GAUTHIER, Philippe. The movie theater as an institutional space and framework of signification: Hale's Tours and film historiography. In: Film History 21, no. 4, 2009.

GONZAGA, Alice. Palácios e poeiras: 100 anos de cinema no Rio de Janeiro. Rio de Janeiro: Record/Funarte, 1996.

GUIA official da Exposição Nacional de 1908. Rio de Janeiro: Tavaresa Oliveira, 1908.

GUNNING, Tom. The world as object lesson: cinema audiences, visual culture, and the St. Louis World's Fair, 1904, Film History 6, no. 4, 1994.

Campinas, Unicamp, 1995.

O cinema das origens e o espectador incrédulo. Revista Imagens, no. 5,

HANSEN, Miriam. Babel and Babylon: spectatorship in American silent film. Cambridge, Mass.: Harvard University Press, 1991.

HUHTAMO, Erkki. Illusions in motion: media archeaology of the moving panorama and related spectacles. Cambridge e Londres: The MIT Press, 2013. 
(Un)walking at the Fair: about mobile visualities at the Paris Universal Exposition of 1900. Journal of visual culture, vol. 12(1). Los Angeles, London, New Delhi, Singapore and Washington D.C.: SAGE Publications, 2013.

KIEHN, David. A trip down Market Street before the fire. Library of Congress. Disponível em: < http://www.loc.gov/programs/static/national-film-preservationboard/documents/Trip\%20Down\%20Market\%20Street.kiehn.pdf >. Acesso em: 20/07/2019.

The brothers who filmed the Earthquake. San Francisco Silent Film Festival. Disponível em: http://www.silentfilm.org/archive/the-brothers-who-filmed-theearthquake. Acesso em: 20/07/2019.

KIRBY, Lynne. Parallel Tracks: the railroad and silent cinema. Durham: Duke University Press, 1997.

LAPERA, Pedro Vinicius Asterito. "Fitas em chammas": cinema, imprensa e sensacionalismo na Belle Époque carioca. Revista brasileira de História, vol. 39, n. 80, $14 / 03 / 2019$.

LEJA, Michael. Seeing, touching, fleeing. In: MATHEWS, Nancy M. with Charles Musser. Moving pictures: american art and early film 1880-1910. Williamstown: Williams College Museum of Art, 2005.

LEMBRANÇA da Exposição Nacional do Rio de Janeiro: com vistas da exposição, da capital federal e breves descripções. São Paulo: Temistocle Severi, 1908.

LEVY, Ruth Nina Vieira Ferreira. Entre palácios e pavilhões: a arquiterura efêmera da Exposição Nacional de 1908. Dissertação (Mestrado em História da Arte). Universidade Federal do Rio de Janeiro, Centro de Letras e Artes, 1998.

LEWIS, Leslie Anne. The Corrick Collection 7 in: LE Giornate del Cinema Muto, Pordenone, 5-12 ottobre 2013: Catálogo.

MANNONI, Laurent. Eclipse. In: ABEL, Richard (Ed.). Encyclopedia of early cinema. New York: Routledge, 2005.

MARIANI, Luiza Helena. Bilac, João do Rio e a Exposição Nacional de 1908. In: PEREIRA, Margareth da Silva (Org.). 1908: Um Brasil em Exposição. São Paulo: Casa $12,2011$.

MATTOS, Carlos Alberto. Coisas nossas. Notas sobre alguns gêneros tipicamente brasileiros. Disponível em: < http://www.bcc.org.br/textos/225970 >. Acesso em: 10/07/2019.

MORAES, Julio Lucchesi. O magnata de Valência: capitalistas, bicheiros e comerciantes do primeiro cinema no Brasil (1904-1921). Revista Movimento, n. 1, junho 2012. São Paulo. 
Notas para uma história econômica do cinema brasileiro: o caso da firma Marc Ferrez \& Filhos. Revista da Cinemateca Brasileira, n. 2, fevereiro 2013. São Paulo.

. Sociedades culturais, sociedades anônimas: distinção e massificação na economia da cultura brasileira (Rio de Janeiro e São Paulo, 1890 - 1922). São Paulo, Programa de Pós-Graduação em História Econômica da Universidade de São Paulo, 2014. Tese (Doutorado em História Econômica).

MORETTIN, Eduardo. Dimensões históricas do documentário brasileiro no período silencioso. Revista Brasileira de História. V. 25, No. 49. São Paulo, 2005.

. As exposições universais e o cinema: história e cultura. Revista Brasileira de História. São Paulo, v. 31, no. 61, 2011.

O Rio de Janeiro no documentário brasileiro do período silencioso: imagens, circuitos e formulações críticas. In: KUSHNIR, Beatriz; VIEIRA, João Luiz. Rio: 450 anos de cinema. Rio de Janeiro: Em Tempo; FAPERJ, 2016.

MUSSER, Charles. The emergence of cinema: the american screen to 1907. Berkeley / Los Angeles: University of California Press, 1990.

Before the Nickelodeon: Edwin S. Porter and the Edison Manufacturing Company. Berkeley / Los Angeles / Oxford: University of California Press, 1991.

Rethinking early cinema: cinema of attractions and narrativity. In: STRAUVEN, Wanda (Ed.). The cinema of attractions reloaded. Amsterdam: Amsterdam University Press, 2006.

NEEDELL, Jeffrey. Belle Époque tropical: sociedade e cultura de elite no Rio de Janeiro na virada do século. São Paulo: Companhia das Letras, 1993.

NORONHA, Jurandyr. No tempo da manivela. Rio de Janeiro: Editora Brasil-América (Ebal); Kinart Cinema e Televisão; Embrafilme, 1987.

PAIVA, Samuel; SCHVARZMAN, Sheila. (Orgs.). Viagem ao cinema silencioso do Brasil. Rio de Janeiro: Beco do Azougue, 2011.

PAUL, Robt. W. Catalogue of selected animated photograph films. Section B, 1906-7. Londres: Animatograph Depot, 1906.

PONTES, Igor Andrade. Os caminhos de Carlitos: a exibição dos filmes de Charles Chaplin no Rio de Janeiro, suas histórias e seus personagens (1914-1922). Dissertação (Mestrado em Comunicação Social). Universidade Federal Fluminense, Instituto de Arte e Comunicação Social, 2016.

RABINOVITZ, Lauren. 'Bells and Whistles': The Sound of Meaning in Train Travel Film Rides. In: ABEL, Richard; ALTMAN, Rick (Eds.). The Sounds of Early Cinema. Bloomington: Indiana University Press, 2001. 
Amusement parks. ABEL, Richard (Ed.). Encyclopedia of Early Cinema. New York: Routledge, 2005.

Phantom train rides. ABEL, Richard (Ed.). Encyclopedia of early cinema. New York: Routledge, 2005.

Thrill Ride Cinema: Hale's Tours and Scenes of the World. In: Electric Dreamland: Amusement Parks, Movies, and American Modernity. New York: Columbia University Press, 2012.

RIO, João do. Modern girls. In: Vida vertiginosa. Rio de Janeiro: Livraria Garnier, 1911.

SANTOS, Guilherme Soares dos. "Minha língua estrangeira é a velocidade, é a aceleração do real". Entrevista com Paul Virilio. Le Monde Diplomatique Brasil. Disponível em: <http://diplomatique.org.br/minha-lingua-estrangeira-e-a-velocidade-ea-aceleracao-do-real/>. Acesso em: 20/05/2017.

SEVCENKO, Nicolau. Literatura como missão: tensões sociais e criação cultural na Primeira República. São Paulo: Brasiliense, 1983.

A capital irradiante: técnica, ritmos e ritos do Rio. In: NOVAIS, Fernando A. (Coordenador-geral); SEVCENKO, Nicolau (Org.). História da vida privada no Brasil. República: da Belle Époque à Era do Rádio. Vol. 3. São Paulo: Companhia das Letras, 1998.

Naify, 2010.

. A Revolta da Vacina: Mentes insanas em corpos rebeldes. São Paulo: Cosac

SOUZA, José Inácio de Melo. Imagens do passado: São Paulo e Rio de Janeiro nos primórdios do cinema. São Paulo: Editora Senac, 2004.

Salas de cinema e história urbana de São Paulo (1895-1930): o cinema dos engenheiros. São Paulo: Senac, 2016.

STEWART, Susan. On longing: Narratives of the miniature, the gigantic, the souvenir, the collection. Durham and London: Duke University Press, 1993.

TINHORÃO, José Ramos. A música popular no romance brasileiro, Vol. III: século XX, $2^{\mathrm{a}}$ parte. São Paulo: Editora 34

TOULET, Emmanuelle. Cinema at the Universal Exposition, Paris, 1900. In: Persistence of Vision, no. 9, 1991.

TOULMIN, Vanessa. Electric Edwardians: the story of the Mitchell \& Kenyon Collection. London: British Film Institute, 2006.

TRUSZ, Alice. Entre lanternas mágicas e cinematógrafos: as origens do espetáculo cinematográfico em Porto Alegre (1861-1908). São Paulo: Editora Terceiro Nome, 2010. 
TSIVIAN, Yuri. Early cinema in Russia and its cultural reception. Chicago e Londres: The University of Chicago Press, 1998.

VELLOSO, Monica Pimenta. As distintas retóricas do moderno. In: OLIVEIRA, Claudia de; VELLOSO, Monica Pimenta; LINS, Vera. O moderno em revistas: representações do Rio de Janeiro de 1890 a 1930. Rio de Janeiro: Garamond, 2010.

VIRILIO, Paul. The original accident. Cambridge, Malden: Polity Press, 2007.

XAVIER, Ismail. O discurso cinematográfico: a opacidade e a transparência. São Paulo: Paz e Terra, 2005.

- Progresso, disciplina fabril e descontração operária: retóricas do documentário brasileiro silencioso. ArtCultura, Vol. 11, No. 18, jan-jun 2009. 